\title{
Herbarium Polonorum (Heimatphotographie)
}

\author{
Elżbieta Janicka
}

\begin{abstract}
Abstrakt: Osnową tekstu jest wojenna i powojenna historia terenu niemieckiego nazistowskiego obozu zagłady Treblinka II z perspektywy produkcji krajobrazu - ze szczególnym uwzględnieniem aspektu tożsamościowego, czyli unarodowienia natury i naturalizacji narodu. Wywód odnosi się do towarzyszących tej produkcji konwencji obrazowania w fotografii przyrodniczej i krajoznawczej, takich jak niemiecka Heimatphotographie i polska fotografia ojczysta.

Poruszone zostało też zagadnienie klasyfikacji jako zasady funkcjonowania ludzkiego umysłu wraz z jej zastosowaniami poznawczymi oraz/lub tożsamościowymi - do morderczych konsekwencji włącznie. Ważny punkt odniesienia stanowi ponadto historia zielnika jako formy organizacji wiedzy (Maria Sibylla Merian, Róża Luksemburg, Szymon Syreński) oraz jej związki ze w sztukami wizualnymi (Krzysztof Jung, Alina Szapocznikow).

Bogaty materiał ilustracyjny odnosi się do analizowanych sposobów reprezentacji ze szczególnym uwzględnieniem aksjosemiotyki polskiego antysemityzmu, sięgając do jego elitarnych form w Polsce Jagiellonów. Tekst podsumowuje piętnaście lat pracy autorki nad projektem fotograficznym Zielnik na terenie byłego niemieckiego nazistowskiego obozu zagłady Żydów Treblinka II.

Wyrażenia kluczowe: antysemityzm; Heimatphotographie; Holokaust; krajobraz; fotografia przyrodnicza; historia środowiskowa; Treblinka; zielnik
\end{abstract}

To jest próba wyjaśnienia i usprawiedliwienia pracy fotograficznej pod tytułem Zielnik, którą prowadzę od piętnastu lat na terenie byłego niemieckiego nazistowskiego obozu zagłady Żydów Treblinka II.

Gdzie wiatr zawiewa dymem z krematorium I dzwoni w wioskach dzwon na Anioł Pański [...] Ziemia zagłady, ziemia nienawiści, Żadne jej nigdy słowo nie oczyści, Taki się na niej nie zrodzi poeta. Czesław Miłosz (Miłosz, 1957/1984, s. 23) ${ }^{1}$

\section{Wizja lokalna}

\section{Wtedy}

Co było na początku? Nie wiadomo. Przed 1942 rokiem były tam pola uprawne: sprawowane przez lata uprawy najprawdopodobniej ziemniaków lub zboża. W roku 1942 uprawa roli ustąpiła miejsca innego rodzaju uprawie. Agrokultura - innego rodzaju kulturze czy produkcji obejmującej szereg kolejnych etapów.

1 Następnie zaś czytamy: „A gdyby nawet jeden był wezwany, / Z nami szedł razem do ostatniej bramy / Bo mógł być tylko między dziećmi z getta” (Miłosz, 1957/1984, s. 29). 
1942: ustanowienie przez III Rzeszę obozu zagłady i masowe zabijanie w komorach gazowych żydowskich obywateli Polski przez austriackich i niemieckich nazistów w asyście ukraińskich pomocników. Kopanie masowych grobów i zakopywanie w nich zwłok. Przez trzynaście miesięcy - niewiele ponad rok - działalności Treblinka II stała się głównym miejscem przemysłowej rzezi Żydów Polski z liczbą ofiar wynoszącą co najmniej 900 tysięcy².

1943: wykopywanie i palenie na otwartym powietrzu ciał w rozkładzie równolegle z nieprzerwaną eksterminacją Żydów z okupowanej Polski i innych krajów Europy wraz z okazjonalnymi transportami Romów i Sinti. Ogień Treblinki był widoczny z daleka nocami. Wiatr rozsnuwał wokół dymy, prochy i popioły wraz z zapachem palonego mię$\mathrm{sa}^{3}$. Tłuszcz wytopiony ze zwłok odkładał się na szybach okiennych w promieniu dziesiątków kilometrów. Następne w kolejności było prowizoryczne zakopywanie prochów i innych szczątków: włosów, strzępów skóry, zębów, rozczłonkowanych szkieletów, strzaskanych kości.

Pierwszy transport przybył do Treblinki 23 lipca 1942 roku. 2 sierpnia 1943 roku Żydzi, nieliczni więźniowie stacjonarni, wzniecili powstanie. Przeżyło mniej niż siedemdziesięciu. Znacznie liczniejsi byli ci, którzy zbiegli - także przed powstaniem - lecz nie zdołali utrzymać się przy życiu po tak zwanej aryjskiej stronie. Obóz przestał działać 17 listopada 1943 roku. W tym czasie zasadniczy zrąb przyszłego krajobrazu Treblinki był już wyprodukowany: złoża żydowskich prochów zmieszanych z innymi pozostałościami, organicznymi i nieorganicznymi. Jednakże historia tej formacji krajobrazowej była daleka od zakończenia. Antropogeniczne ruchy tektoniczne i wstrząsy sejsmiczne trwały dalej.

1944: na ogrodzonym terenie poobozowym, zaoranym i obsianym łubinem, kierownictwo obozu zainscenizowało prowizoryczne gospodarstwo rolne z ukraińskimi strażnikami jako obsadą. Armia Czerwona wkroczyła tam latem 1944 roku. Co zaś tyczy się

2 Zob. Abrama Jakuba Krzepickiego Człowiek uciekł z Treblinek... Rozmowy z powracajacym (Krzepicki, 2017), Richarda Glazara Stacja Treblinka (Glazar, 2011), Jechiela Rajchmana Ocalatem z Treblinki. Wspomnienia z lat 1942-1943 (Rajchman, 2011), Eddie Weinsteina, 17 dni w Treblince (Weinstein, 2008), Jankiela Wiernika Rok w Treblince / A Year in Treblinka (Wiernik, 2003) i Samuela Willenberga, Bunt $w$ Treblince (Willenberg, 2004). Por. także tom zawierający jedno świadectwo anonimowe obok świadectw Abrama Krzepickiego (pierwsze wydanie), Dawida Nowodworskiego, Jakuba Rabinowicza Ostatnim etapem przesiedlenia jest śmierć. Pomiechówek, Chełmno nad Nerem, Treblinka (Wiatr, Engelking, \& Skibińska, 2013, ss. 73-222). Pochodzące z 1942 roku świadectwa Krzepickiego, Nowodworskiego i Rabinowicza są współczesne wydarzeniom. Rajchman i Wiernik spisali swoje relacje jako ocalali z powstania w Treblince z 2 sierpnia 1943 roku. Również tekst Weinsteina jest stosunkowo wczesną relacją, jako że pochodzi z roku 1946 lub 1947.

3 W październiku 1942 roku, to jest przed rozpoczęciem palenia zwłok, kwatermistrz dowództwa wojskowego Generalnego Gubernatorstwa notował w dzienniku wydarzeń: „OK [Ortkommandantur] Ostrów [Mazowiecka] melduje, że Żydzi w Treblince nie zostali wystarczająco pochowani i w konsekwencji powietrze zatruwa nieznośny fetor padliny" (BA-MA Freiburg, RH 53-22/80 - wpis z 24 października 1942, KTB MiG, OQu; cyt. za: Młynarczyk, 2013, s. 88). Ostrów Mazowiecka jest położona 25 kilometrów na północ od Treblinki. Analogiczne przykłady z 1943 roku z Węgrowa i Sokołowa Podlaskiego - w promieniu 35 kilometrów na południe od Treblinki - przytacza Martyna Rusiniak (Rusiniak, 2008, s. 19).

4 Por. wydana po polsku następnego roku broszura Wasilija Grossmana, Piekło Treblinki. Reportaż literacki (W. Gros[s]man, 1945). Tekst Grossmana wszedł następnie w skład tomu Czarna księga pod redakcją Ilji Erenburga, Wasilija Grossmana jako Treblinka (W. Grossman, 2020). Grossman pisze, że przybył na miejsce na początku września 1944 roku. 
samego gospodarstwa, wybudowano je z cegieł uzyskanych z rozbiórki komór gazowych. Po rozebraniu budynków gospodarczych te same cegły posłużyły do wzniesienia trzech domów prywatnych w sąsiedniej wsi Poniatowo 5 .

1945: początek dynamicznej działalności miejscowej i zamiejscowej polskiej ludności chrześcijańskiej eksplorującej prochy i popioły, ekskrementy oraz wszelkie inne pozostałości po ofiarach w poszukiwaniu fantazmatycznego „żydowskiego złota”. W najwcześniejszych relacjach powojennych - autorstwa Racheli Auerbach (Auerbach, 2012b) ${ }^{6}$ i Mordechaja Canina (Canin, 2018c) ${ }^{7}$ - zjawisko to zostało określone mianem gorączki złota (Auerbach, 2012a; Canin, 2018a). Stan faktyczny był ponadto dokumentowany przez Centralną Żydowską Komisję Historyczną, Centralny Komitet Żydów Polskich, państwową Główną Komisję Badania Zbrodni Niemieckich w Polsce, prasę kontrolowaną przez rząd, Polską Kronikę Filmową, w świadectwach, raportach posterunku milicji (w dawnej mykwie) w pobliskim Kosowie Lackim oraz aktach postępowań sądowych.

Polscy chrześcijanie prowadzili eksploatację miejsca zbrodni głównie za pomocą prostych narzędzi rolniczych. Jakkolwiek grunt bywał także wysadzany w powietrze przy użyciu materiałów wybuchowych, gdy do kopaczy dołączali wojskowi - radzieccy i polscy - których zadaniem była ochrona terenu (Rusiniak, 2008, s. 32; zob. też Gross \& Grudzińska-Gross, 2011; Reszka, 2019). Jak wyraziła się Martyna Rusiniak: „Wyczyny poszukiwaczy bezcześciły pamięć pomordowanych, zarazem [zaś] świadczyły o znajomości historii wojennej byłego obozu". Rusiniak opisuje prowadzone manewry jako pamięć lokalną: „Była to jednak pamięć specyficzna, a mianowicie miejscowych poszukiwaczy o tym miejscu jako o «Eldorado Podlasia»" (Rusiniak, 2008, s. 93; zob. też Borejsza, 2018) ${ }^{8}$. Rachela Auerbach pisała o „polskim Kolorado” i „polskim Klondike”, podobnie jak dziennikarze prasy lokalnej i centralnej. Tę żywą pamięć należy lokować i postrzegać w kontinuum z wojennymi praktykami społecznymi wokół Treblinki II. Oddolne działania terenowe trwały do początku - jeśli nie do połowy - lat sześćdziesiątych.

1964: podczas gdy żywa pamięć była kultywowana w najlepsze, władze centralne narzuciły miejscowym i miejscu pamięć znacznie mniej żywą w postaci założenia po-

5 United States Holocaust Memorial Museum, Poland Documentation Project, RG-50.225*0032, relacja audio Jerzego Skarżyńskiego i Eugeniusza Wójcika zarejestrowana 12 marca 1998 roku (cyt. za: Rusiniak, 2008, s. 33).

6 Oryginalny, autorski tytuł reportażu brzmiał Ojf di felder fun Treblinke [Na polach Treblinki]. Rachela Auerbach napisała Ojf di felder fun Treblinke w 1946 roku w Łodzi. Broszura została opublikowana w „Dos Naje Lebn” w tym samym roku tamże, a rok później jako osobny druk w Warszawie przez Centralną Żydowską Komisję Historyczną. Tekst był relacją z ekspedycji zbrojnej na teren byłego obozu zagłady Treblinka II w dniu 7 listopada 1945 roku. Wyprawa ta, fałszywie przedstawiona w filmie Roberty Grossman Kto napisze nasza historię (R. Grossman, 2018) jako samotna podróż Racheli Auerbach, była dziełem połączonych sił Centralnej Żydowskiej Komisji Historycznej i państwowej Głównej Komisji Badania Zbrodni Niemieckich w Polsce. Jako członkini zespołu Oneg Szabat, zwanego dzisiaj Archiwum Ringelbluma, Rachela Auerbach odbierała świadectwo z Treblinki od Abrama Krzepickiego jeszcze w warszawskim getcie w 1942 roku.

7 Tekst Treblinke Canina był zapisem wizji lokalnej przeprowadzonej przez autora w 1946 lub 1947 roku i stanowit integralną część zbioru jego reportaży lber sztejn un sztok. A rajze iber hundert chorewgeworene kehiles in Pojln opublikowanego w 1952 roku w Tel Awiwie.

8 Dziękuję Annie Sianko za zwrócenie mojej uwagi na relację Borejszy. 
mnikowego autorstwa Franciszka Duszeńki, Adama Haupta i Franciszka Strynkiewicza9. Zespół - złożony z dwóch rzeźbiarzy, architekta oraz architektki krajobrazu, Danuty Oppenheim - wygrał konkurs ogłoszony w roku 1955 przez Ministerstwo Kultury i Sztuki z inicjatywy Towarzystwa Społeczno-Kulturalnego Żydów w Polsce ${ }^{10}$. Zwycięski projekt obejmował obydwa byłe obozy: obóz pracy przymusowej Treblinka I (czynny od jesieni 1941 do lata 1944 roku) i obóz zagłady Treblinka II wraz z tak zwaną Czarną Drogą łączącą oba miejsca ${ }^{11}$.

Wiele można by powiedzieć o kommemoratywnej orkiestracji dwóch byłych obozów w sensie ich wzajemnego usytuowania. W przeciwieństwie do faktów historycznych Treblinka I - z zatrzęsieniem mniejszych krzyży i większym krzyżem centralnym, uzupełnionymi Drogą Krzyżową - została przedstawiona jako miejsce wyłącznie polskiej martyrologii chrześcijańskiej ${ }^{12}$, wyprzedzającej w czasie swój „żydowski ekwiwalent”. Odpowiednikiem tego układu jest orkiestracja kommemoratywna Auschwitz I i Auschwitz II Birkenau.

Co się tyczy siedemnastu hektarów byłej Treblinki II:

Granice byłego obozu oznaczono ustawiając olbrzymie granitowe słupy. Brama wejściowa została upamiętniona dwoma betonowymi blokami, przez środek której [sic! - E. J.] biegnie w kierunku rampy brukowana droga. Betonowe bloki prowadzące do rampy - to symboliczne tory kolejowe, pomysł Adama Haupta. Obok rampy znajduje się 11 kamieni z wykutymi nazwami państw, z których byli przywożeni Żydzi do obozu. Od rampy do pomnika biegnie brukowana droga, która prowadziła do komór gazowych. Po obu jej bokach poprzez kamienie zaznaczono rozbieralnie. Na miejscu, gdzie znajdowały się nowe komory gazowe, wznosi się wysoki pomnik, autorem którego jest Franciszek Duszeńko. Zbudowany jest on z dużych bloków granitowych, które swoim ułożeniem przypominają Ścianę Płaczu w Jerozolimie. Frontowa ściana robi wrażenie pękniętej przez środek. [...] Przed pomnikiem napis „NIGDY WIĘCE]”

9 Strynkiewicz projektował symboliczną ścianę straceń w Treblince I. Ponadto jako wykładowca i kierownik Zakładów Artystyczno-Badawczych Akademii Sztuk Pięknych w Warszawie był odpowiedzialny za całość realizacji. Adam Haupt był architektem i rektorem Wyższej Szkoły Sztuk Plastycznych w Gdańsku, gdzie Franciszek Duszeńko kierował Wydziałem Rzeźby. Na temat pierwszego - ostatecznie niezrealizowanego - założenia pomnikowego autorstwa Władysława Niemca i Alfonsa Zielonki zob. Wóycicka, 2009.

10 „Dopiero pod koniec lat 50-tych, pod wyraźną presją toczących się w Niemczech zachodnich procesów zbrodniarzy wojennych i w obawie przed opinią delegacji prokuratury zachodnioniemieckiej przybyłej na teren byłego ośrodka zagłady, postanowiono zrealizować projekt pomnika-mauzoleum, upamiętniającego ofiary i miejsca zagłady w Treblince" (Szuchta, 2013, s. 36). Artur Paweł Zawadka tymczasem pozostawia czytelnika z wrażeniem, że opóźnienie zostało spowodowane przez żydowskie organizacje w Polsce i na świecie, które nie zebrały dostatecznej sumy pieniędzy dostatecznie szybko. Osobistą odpowiedzialnością w tym względzie obciąża autor Salo Fiszgrunda, który w rzeczywistości był jednym z najaktywniejszych orędowników projektu. Innymi słowy, Artur Paweł Zawadka, reprezentujący Radę Ochrony Pomników Walk i Męczeństwa (przemianowaną na Radę Ochrony Pamięci Walk i Męczeństwa) pięćdziesiąt lat później, rezygnuje z podejścia analitycznego do archiwów macierzystej instytucji, jak i polityki historycznej państwa polskiego w przeszłości. Spektakularny, choć nieodosobniony to przykład lojalności Polaków ponad politycznymi podziałami tam, gdzie chodzi o Żydów - żywych lub martwych, bez różnicy (Zawadka, 2015).

11 Reinhart Koselleck starannie udokumentował zespół kommemoracyjny, włączając weń istniejącą wówczas jeszcze stację kolejową we wsi Treblinka (być może w ślad za Claudem Lanzmannem). Jego prace fotograficzne można obejrzeć na stronie internetowej Bildarchiv Marburg. Por. https://www.bildindex.de/document/que20173128?part=1 i https://www.bildindex.de/document/que20173131?part=1 (odnośnie do Treblinki II) oraz https://www.bildindex.de/document/que20173134?part=1 (odnośnie do Treblinki I) (dostęp 20.08.2019). Dziękuję Katrin Stoll za zwrócenie mojej uwagi na działania Kosellecka jako fotografa, w tym na wystawę Reinhart Koselleck. Erinnerungsschleusen w Bielefeld Kunstverein zorganizowaną przez Uniwersytet w Bielefeld w 2018 roku.

12 Pomnik Romów i Sinti ofiar Treblinki I oraz Treblinki II został wzniesiony na terenie byłego obozu pracy przymusowej w 2014 roku. 


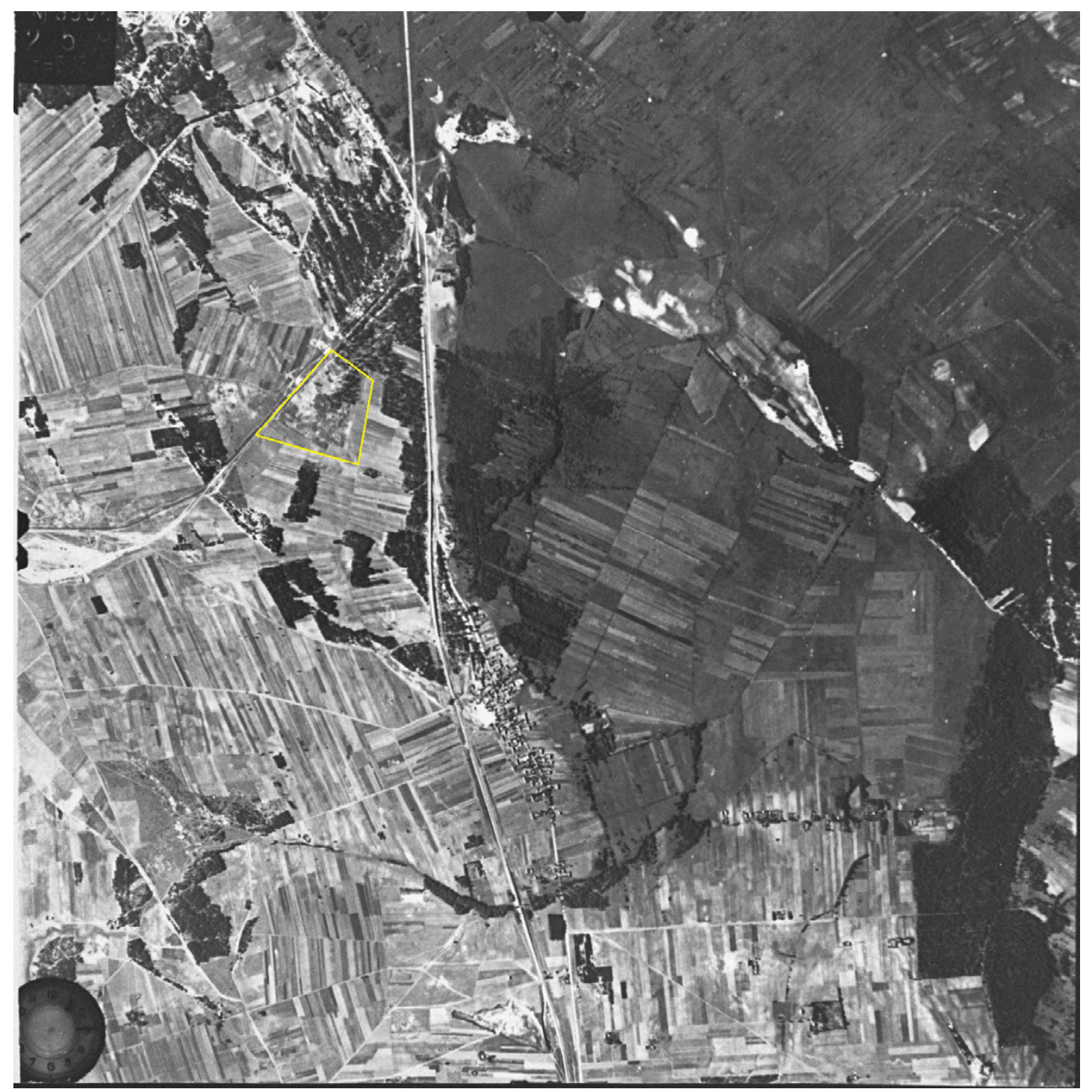

Niemiecka fotografia lotnicza Treblinki II i okolic po 30 listopada 1943 (ze zbiorów United States Holocaust Memorial Museum - sygnatura 04403, dzięki uprzejmości National Archives and Records Administration, College Park)

Z góry na dół przecina obraz regularna linia kolejowa równoległa do betonowej drogi samochodowej wylewanej w szalunkach na tłuczniu z macew z Kosowa Lackiego w latach 1940-1941. Treblinka II znajduje się przy bocznym, ślepym torze prowadzącym do żwirowni przy obozie niewolniczej pracy Treblinka I. Wyrobisko żwirowni widać w połowie lewej krawędzi fotografii. Wzdłuż wschodniej - tu prawej - granicy obozu Treblinka II, przy samych drutach, widoczna droga gruntowa 


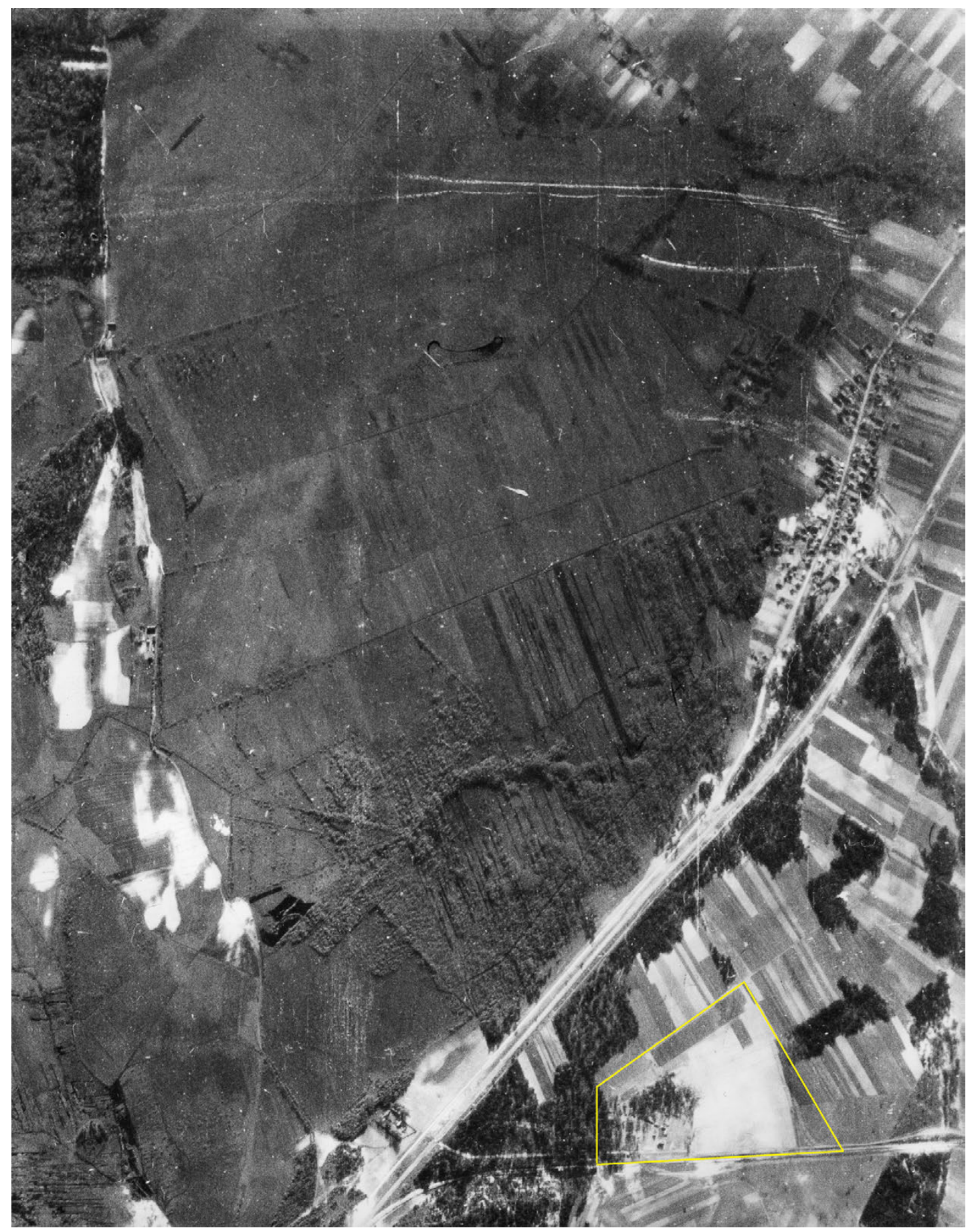

Niemiecka fotografia Lotnicza Treblinki II i okolic - w okresie najprawdopodobniej późniejszym, lecz przed wkroczeniem Armii Czerwonej (ze zbiorów United States Holocaust Memorial Museum - sygnatura 04163, dzięki uprzejmości National Archives and Records Administration, College Park)

Równolegle do dolnej krawędzi fotografii biegnie boczny tor kolejowy i zachodnia granica obozu Treblinka II. Widoczna droga gruntowa wzdłuż granicy wschodniej oraz biegnąca równolegle do niej regularna linia kolejowa wraz z betonową drogą samochodową, której odnoga prowadzi do zabudowań wsi Wólka Okrąglik widocznych w połowie zdjęcia z lewej strony 


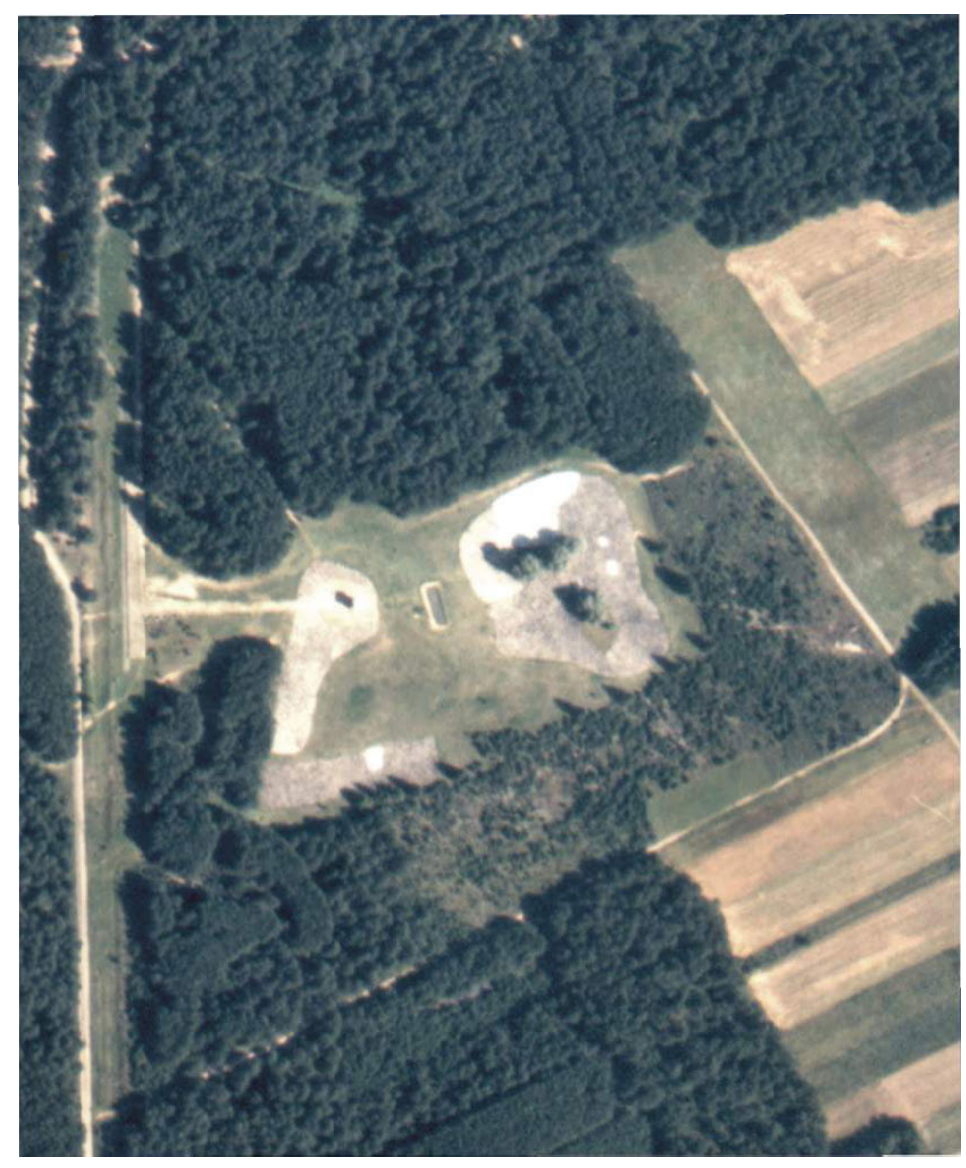

Teren byłego obozu Treblinka II w czasie porównywalnym z okresem zdjęciowym Shoah Claude'a Lanzmanna. Ekipa Shoah operowała

na miejscu czterokrotnie między lipcem 1978 a grudniem 1981 roku (๔ by ARC www.deathcamps.org)

Wzdłuż wschodniej granicy byłego obozu widoczna stara droga gruntowa oraz brak lasu. Lasu nie ma także wzdłuż wschodniej połowy obozowe granicy od południa

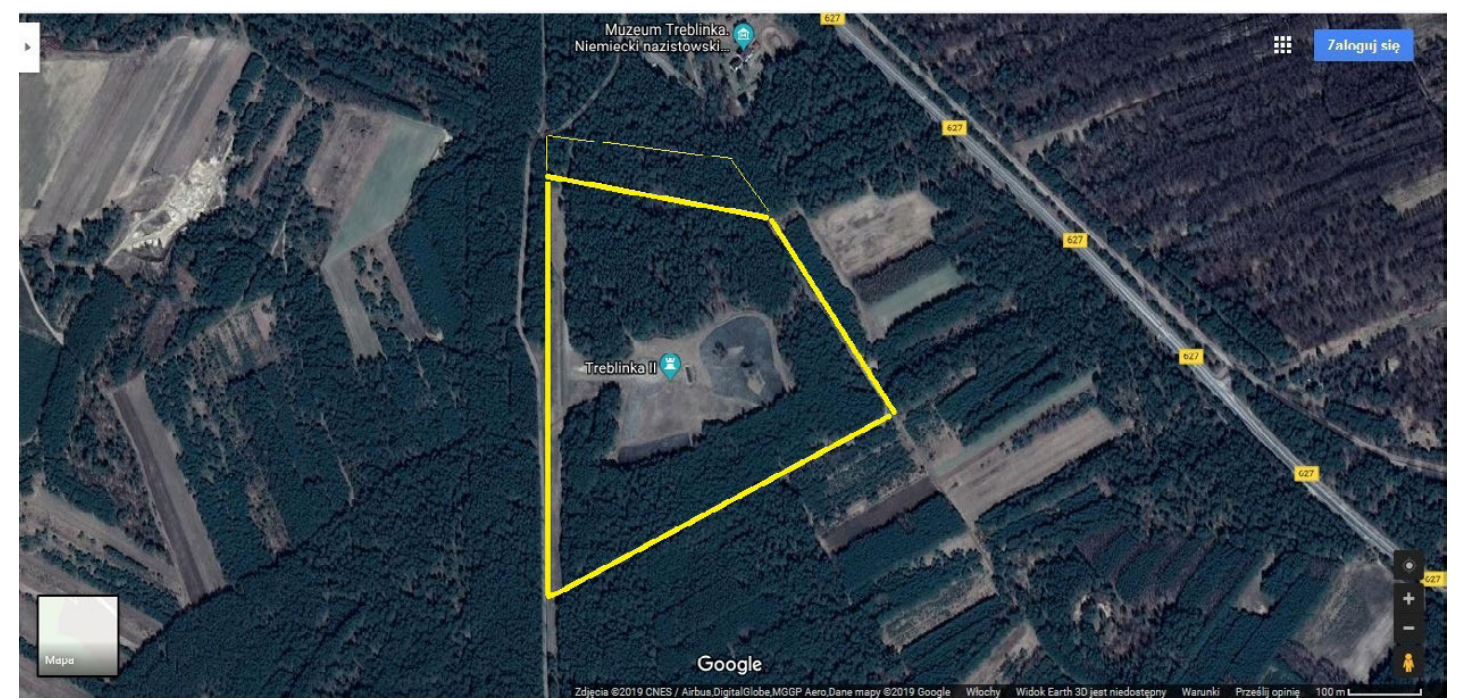

To samo miejsce w 2019 roku wedkug Google Maps

W 2020 roku las wzdłuż wschodniej granicy byłego obozu został wycięty, podobnie jak wschodnia połowa pasa leśnego wzdłuż granicy południowej. Gruby kontur odpowiada upamiętnieniu granic Treblinki II przez Adama Haupta. Rozbieżność między upamiętnieniem a stanem faktycznym dotyczy granicy północnej, która najprawdopodobniej była wysunięta bardziej na północ, czemu odpowiada cienki kontur 

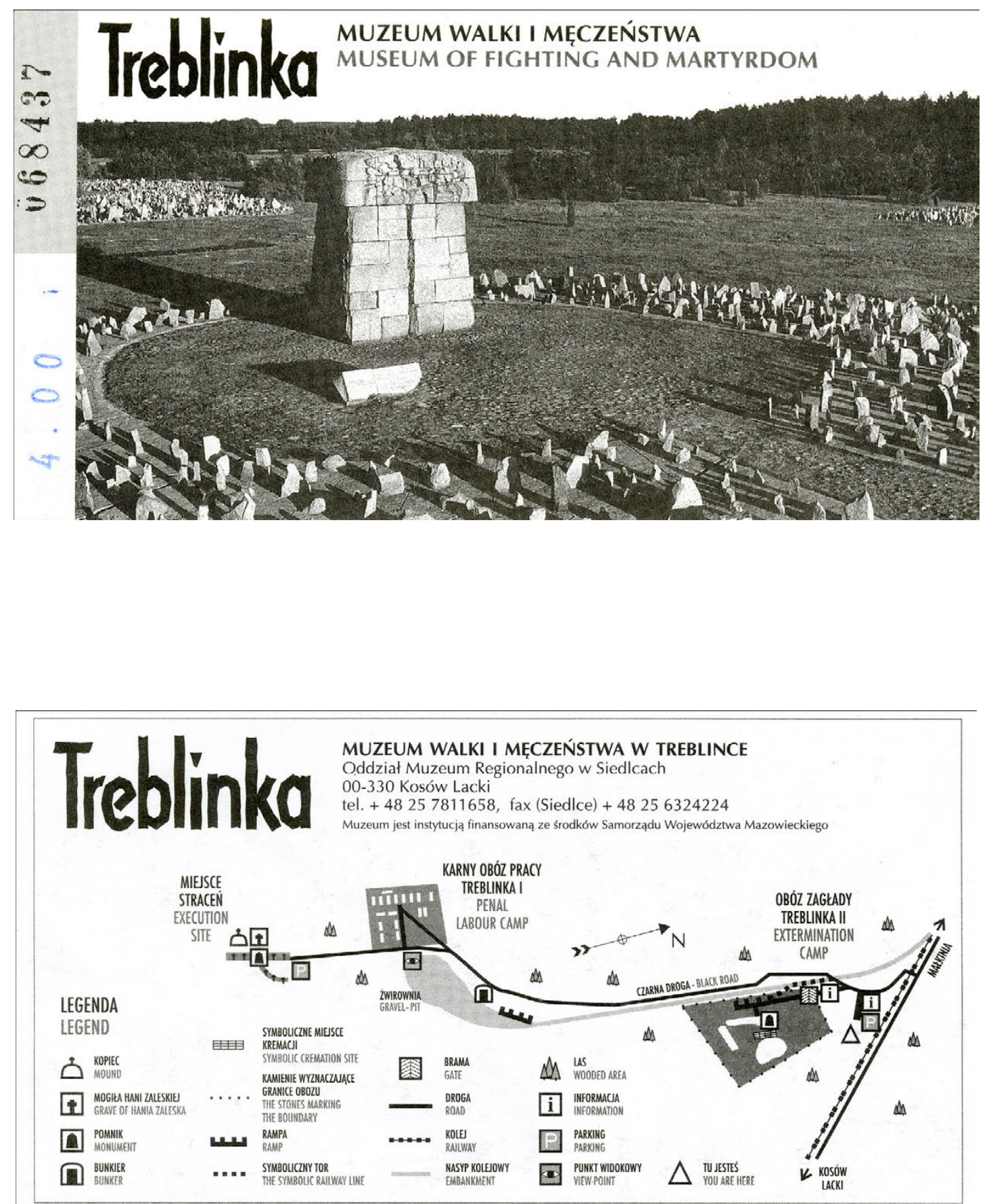

Bilet wejściowy przedstawiający ukończone w 1964 roku upamiętnienie Treblinki II autorstwa Adama Haupta, Franciszka Duszeńki i Franciszka Strynkiewicza (awers) oraz wzajemne usytuowanie obozów Treblinka I i Treblinka II połączonych Czarną Drogą (rewers) (fot. Elżbieta Janicka) 
w języku polskim, hebrajskim, jidysz, rosyjskim, angielskim, francuskim i niemieckim. [Hebrajski dodano w 2004 roku - E. J.] [...] Za pomnikiem w prostokątnym zagłębieniu znajduje się symboliczne miejsce, gdzie palono zwłoki. Jest to prostokątny dół wypełniony stopionym czarnym bazaltem, tworzącym nieregularne skrzepy i sople. Wokół zagłębienia ustawiono kilkanaście lamp na ciekłe paliwo, które po zapaleniu do złudzenia przypominają, iż na tym miejscu płonął stos złożony z ludzkich ciał. Autorem tego upamiętnienia jest Adam Haupt. 22 tys. $\mathrm{m}^{2}$ powierzchni zostało pokryte betonem, a na nim ustawiono 17 tysięcy różnej wielkości ciosów granitowych. Beton ten przykrywa prochy pomordowanych ludzi. [...] Kamienie symbolizują macewy - nagrobki na żydowskim cmentarzu (Kopówka, 2014, ss. 3-4) ${ }^{13}$.

Takie jest moje theatrum operandi pod otwartym niebem.

\section{Teraz}

Rozumowanie Duszeńki, Haupta i Strynkiewicza łączyło pojęcie pomnika rozumianego jako rzeźba (rozumiana z kolei jako bryła) z architekturą krajobrazu i planowaniem przestrzennym bliskim dokonanej przez Katarzynę Kobro rewolucyjnej redefinicji rzeźby jako kompozycji przestrzeni (zob. Kobro \& Strzemiński, 1931/1993). Ta sama lub podobna szkoła myślenia przejawiła się w - niezrealizowanym ostatecznie - projekcie Drogi, pomnika dla Auschwitz II Birkenau z 1957 roku, współautorstwa Oskara Hansena, Jerzego Jarnuszkiewicza, Juliana Pałki, Lechosława Rosińskiego, Edmunda Kupieckiego, Tadeusza Plasoty i Zofii Hansen, którzy pracowali na przedłużeniu koncepcji Formy Otwartej Oskara Hansena (zob. Murawska-Muthesius, 2002; Pietrasik, 2010; Grzesiuk-Olszewska, 2019). Oba zespoły postrzegały każde z miejsc jako jego własną reprezentację. Jako znak i desygnat jednocześnie. Niemożliwe do przedstawienia czy w ogóle potraktowania inaczej niż 1:1. W tej optyce nie było innej możliwej mapy Treblinki i Brzezinki, jak tylko identyczna z ich terytorium. Praktycznie bez możliwości symbolizacji.

Projekt dla Treblinki II zawiera dwa element inwazyjne. Wertykalną bryłę potocznie zwaną pomnikiem i rozumianą jako pomnik. Oraz horyzontalne płyty betonowe pokrywające dużą część powierzchni. Beton wylano wskutek nalegań Hersza Smolara (komunistycznego przywódcy powstania Żydów w getcie mińskim i jednego z liderów powojennego życia żydowskiego w Polsce). Dla Smolara zabezpieczenie cielesnych szczątków ofiar stanowiło kwestię zasadniczą i naglącą (zob. Rusiniak, 2008, s. 37). Ten sam imperatyw był udziałem Adama Haupta. W praktyce funkcję ochronną pełnią zarówno betonowe płyty, jak granitowa bryła. Bryła upostaciowuje stare ambicje rodzaju monumentalnego: dominować i definiować przestrzeń. Jako taka istotnie przyciąga główny strumień odwiedzających - niezależnie od tego, czy przybywają z wizytą oficjalną, czy prywatnie, indywidualnie czy w grupach. To pod „pomnikiem” mają miejsce uroczystości, tam też składane są wieńce. Percepcyjnie zatem „pomnik” broni dostępu do betonowych płyt. Betonowe płyty zaś już dosłownie bronią dostępu do głównych pokładów prochów oraz szczątków.

13 Co się tyczy faktycznego uplasowania poszczególnych części historycznego obozu - które nie odpowiada temu, co sądzono i co opisuje Edward Kopówka - zob. prace Caroliny Sturdy Colls (Sturdy Colls, 2012, 2013, 2015). 
Innymi słowy, zadanie zostało wykonane. Mimo to zawsze wydaje mi się dziwne, że logotypem Muzeum Walki i Męczeństwa w Treblince stał się właśnie „pomnik”, w dodatku widziany od swojej „mniej żydowskiej” strony, podczas gdy betonowe płyty wymknęły się reprezentacji i również in situ umykają uwadze, traktowane jako neutralne podłoże dla kamieni towarzyszących „pomnikowi” ${ }^{14}$, który już zresztą w dokumentacji robót nazywano „obiektem centralnym”.

Wykonany w szarym granicie, „obiekt” ów został zaprojektowany przez Franciszka Duszeńkę w formie megalitu. Konkretnie - w formie klasycznego dolmenu. Oficjalne materiały muzealne przedstawiają go jako „symboliczny grób”. I faktycznie:

Dolmeny są często nazywane grobowcami portalowymi (portal tombs) ze względu na charakterystyczne wejście do komory grobowej, które tworzyły dwa ustawione pionowo głazy nakryte znacznych rozmiarów, zazwyczaj płaskim od spodu kamieniem, stanowiącym rodzaj pokrywy. Określenie dolmen wywodzi się z języka bretońskiego, w którym tolmén oznacza „kamienny stót". W przeciwieństwie do grobowców korytarzowych, które pokrywał kolisty płaszcz kamienny, w dolmenach komora grobowa nakryta była rzadko (Moore i in., 2011, s. 12) ${ }^{15}$.

W zasadniczym swoim zrębie megality były instalacjami ceremonialnymi i grzebalnymi, powiązanymi z paleniem zwłok. Wznoszono je często w oparciu o wiedzę na temat obrotów ciał niebieskich, w szczególności Słońca i Księżyca. „Pomnik” w Treblince jest orientowany ${ }^{16}$.

Megalit to elementarna forma architektoniczna i nie byłoby tutaj nic do dodania, gdyby megality i menhiry nie stały się fascynacją nazistowską o istotowym charakterze $^{17}$. Ich kult był emblematyczny dla nazistowskiego wynalazku germańskiej przeszłości plemiennej. Miały one świadczyć o starożytnym charakterze tak zwanej kultury nordyckiej, co współbrzmiało z ideą tak zwanej rasy aryjskiej jako prehistorycznego źródła kultury. Megality miały kompensować nazistowski kompleks niższości wynikający z braku germańskich osiągnięć architektonicznych równych egipskim, greckim czy rzymskim. Pasowały też do charakterystycznych dla nazizmu: ideału nieśmiertelności, aspiracji do wieczności i milenarystycznej wizji wszechświata.

Doskonałe dopasowanie budowli do okolicy i fakt, że składały się z bloków skalnych, które przyroda oferowała w stanie czystym, bez potrzeby poddawania ich późniejszej obróbce, świetnie wpisywały się w ideał poszanowania środowiska naturalnego, na co naziści powoływali się nawet przy budowie autostrad (Rose, 2006, ss. 145-146).

14 Na temat procesu upamiętniania zob. Radecka, 2013; Zawadka, 2015. Dziękuję Katarzynie Radeckiej, architektce i profesorce Politechniki Koszalińskiej, za szczodre podzielenie się ze mną odkryciami, które złożyły się na płytę DVD Treblinka pod jej redakcją (Radecka, 2011).

15 Przygotowany przez Filię Klubu Młodych Archeologów w Downpatrick katalog towarzyszący wystawie Megality - kamienne giganty / Mega megaliths, która odbyła się w warszawskim Państwowym Muzeum Archeologicznym w październiku i listopadzie 2011 roku.

16 W architekturze orientacja oznacza usytuowanie bryły budynku na osi wschód-zachód. Główna część, jaką w synagodze stanowi Aron-ha-Kodesz, gdzie przechowywane są zwoje Tory, ulokowana jest wówczas od wschodu (tac. oriens). Wejście natomiast znajduje się od zachodu (łac. occidens). Odwrotnością orientacji jest okcydentacja. W budynku usytuowanym na osi wschód-zachód najważniejsza część znajduje się wówczas od strony zachodniej, wejście zaś od wschodu (zob. Landsberger, 1957).

17 W komentarzu na temat pracy Duszeńki Adam Haupt nadmienił, że ośmiometrowa bryła nawiązuje do dolmenów i menhirów. Nie wspomniał jednakże o ich możliwych denotacjach i konotacjach (zob. Haupt, 1961, s. 5). 
Stanowiska megalityczne zostały uznane za germańskie dziedzictwo kulturowe i były traktowane jak nazistowskie święte miejsca. Stąd nazistowska histeria tożsamościowa - będąca udziałem zwłaszcza Heinricha Himmlera i SS - na tle Externsteine, Sachsenhein czy Tannenberga. Stąd nazistowska zazdrość o Stonehenge (zob. hasła: Externsteine, Megality, Stonehenge, Tannenberg, w: Rose, 2006, ss. 73-76, 144-147, 226-227, 239240). „Herman Wirth, współzałożyciel departamentu SS Dziedzictwo Przodków (Ahnenerbe), domagał się uznania, że istniała religia związana z megalitycznymi grobowcami, która miałaby się rozwijać w epoce kamienia i brązu” (Rose, 2006, s. 146). „Jednakże ideologiczna manipulacja megalitami nie ograniczała się do naginania danych; Himmler, przy aprobacie i wsparciu [Alfreda] Rosenberga, przeszedł samego siebie, każąc wybudować niedaleko Verden an der Aller kompletnie nowe miejsce kultu megalitycznego" (Rose, 2006, ss. 146-147). I tak dalej.

Jak to pogodzić z deklarowanym przez Duszeńkę podobieństwem orientowanego „pomnika” w Treblince do zachodniej ściany Świątyni Jerozolimskiej? Rozbieżnymi, pozbawionymi spójności naciskami politycznymi? Intencjonalną subwersją nazistowskich aspiracji jak w przypadku warszawskiego pomnika Bojowników i Męczenników Getta projektu Natana Rapoporta i Leona Marka Suzina, który został obłożony płytami z kamienia przeznaczonego przez nazistów na pomnik Adolfa Hitlera? Cokolwiek to było, na kamiennej pokrywie megalitycznego portalu od zachodu widnieje para błogosławiących rąk, podczas gdy od wschodu przedstawiona została siedmioramienna menora. Dłonie w geście błogosławieństwa to emblemat umieszczany na kamieniach nagrobnych kohanim, potomków arcykapłana Arona, głównego celebransa religijnych nabożeństw ofiarnych w starożytnym Izraelu. Siedmioramienna menora natomiast symbolizuje Drugą Świątynię, jej zburzenie oraz - w myśl zbawczego wariantu syjonistycznej narracji - jej symboliczną odbudowę w postaci państwa Izraela. W momencie wzniesienia „pomnika” w Treblince świecznik siedmioramienny był już od piętnastu lat z okładem oficjalnym symbolem izraelskiej państwowości.

Błogosławiące dłonie i menora są okolone serią płaskorzeźb przedstawiających rozczłonkowane ciała w apogeum cierpienia (kurczowo zaciśnięte palce, otwarte usta, wychodzące z orbit oczy) ${ }^{18}$. Płaskorzeźby zajmują północną, zachodnią i południową stronę kamiennej pokrywy. Są one całkowicie sprzeczne z anikonizmem właściwym judaizmowi, w którym portret YHWH w jakimkolwiek ludzkim i konkretnym kształcie nie jest zalecany, a zakaz odnosi się przede wszystkim do rzeźby. Pozostają za to w harmonii z chrześcijańską tradycją wystawiania na widok publiczny skrajnego cierpienia i zmasakrowanych zwłok - ze zwłokami, które chrześcijanie uważają za ciało Boga i prawdzi-

18 Płaskorzeźby są zatytułowane: Męczeństwo, Kobiety i dzieci, Walka, Przetrwanie. Franciszek Duszeńko nie ułatwił zrozumienia swojej koncepcji, nazywając główną bryłę „ołtarzem ofiarnym” i oznajmiając: „z perspektywy czasu przekonany jestem, [...] że płaskorzeźby pomnika są bardzo ważnym komponentem dramaturgii całego terenu, są jakby pomostem naszej wyobraźni, gdzie ich związek z masowością i umownością znaku - kamienia przykrycia mogił jest najistotniejszym elementem metafizycznej konstrukcji całego terenu obozu zagłady" (cyt. za: Grzesiuk-Olszewska, 1995, s. 250). 


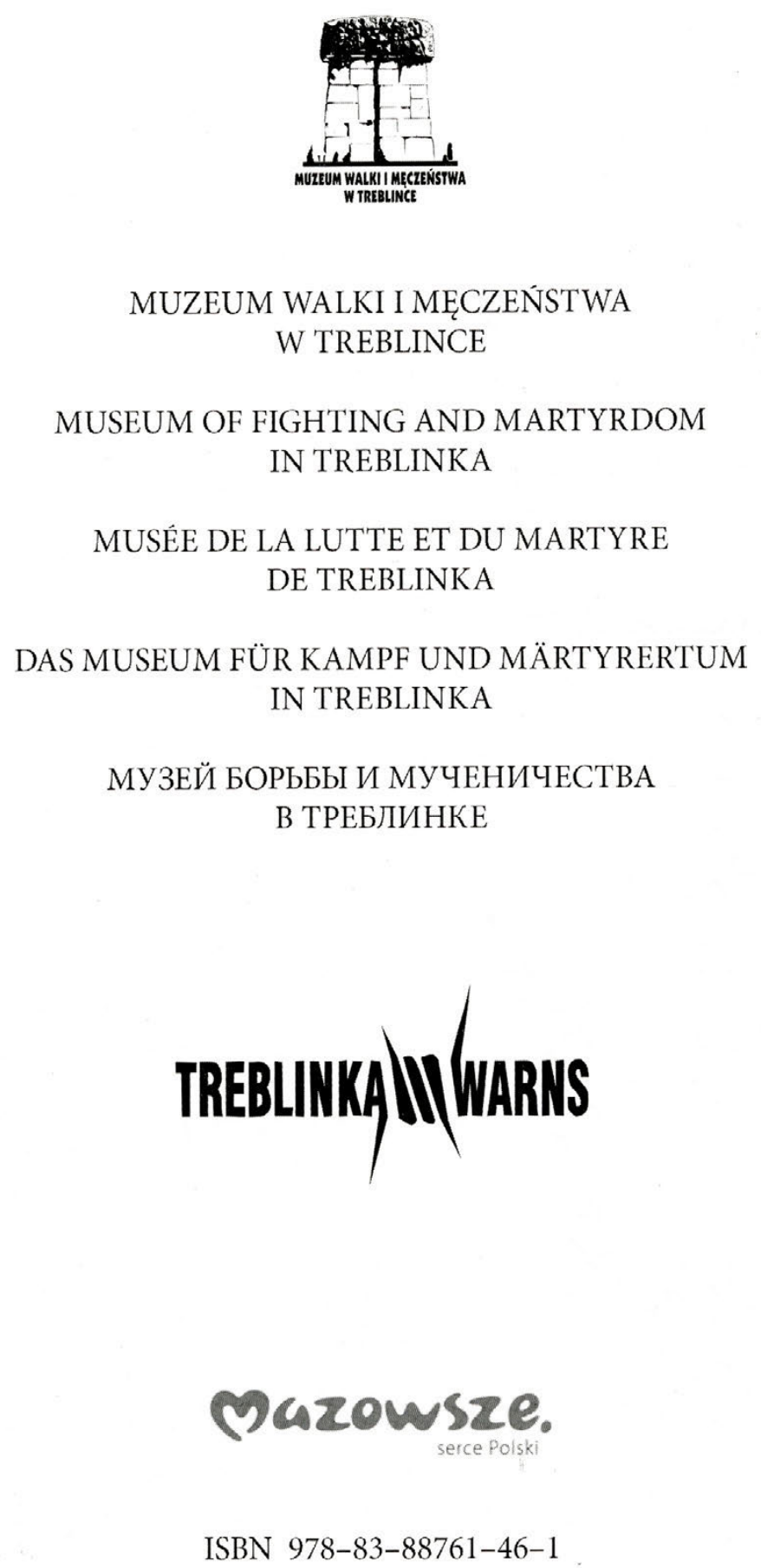

Widok zachodniej („mniej żydowskiej”) strony „obiektu centralnego” projektu Franciszka Duszeńki jako logo Muzeum Walki i Męczeństwa w Treblince wraz z logo Mazowsza „Mazowsze - serce Polski” na okładce broszury: Plan kamieni symbolicznych, red. Edward Kopówka (Kopówka, 2014) (fot. Elżbieta Janicka) 


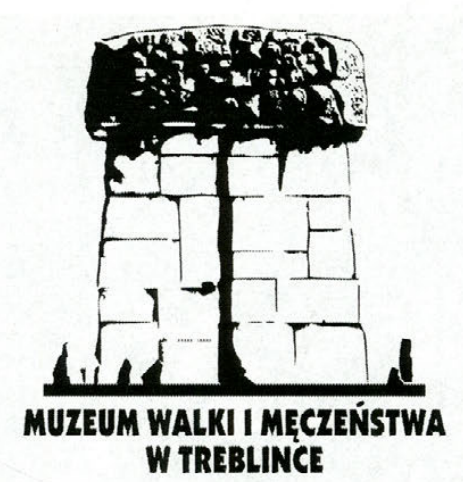

Muzeum Walki i Męczeństwa w Treblince Oddziae Muzeum Regionalnego w Siedlcach

\section{8-330 Kosów Lacki}

Czynne codziennie (oprócz świąt Bożego Narodzenia i Wielkanocy)

$$
\text { w godz. 9-19 }
$$

tel. $+48257811658,+48606985414$

e-mail: biuro@treblinka-muzeum.eu

www.treblinka-muzeum.eu

Raport o stanie zachowania Miejsca Pamięci w Treblince w roku 2013

autorstwa Edwarda Kopówki i Joanny Zasłona jest dostępny na stronie: https://docs.google.com/file/d/OB-2T-oahuSvWcTF1TOZEUzRBZUk/edit?pli=1

\section{Museum of Fight and Martyrdom in Treblinka}

Branch of Regional Museum in Siedlce

\section{8-330 Kosów Lacki}

Opening hours (besides Christmas and Easter)

$$
9 \text { a.m. }-7 \text { p.m. }
$$

tel. $+48257811658,+48606985414$

e-mail: biuro@treblinka-muzeum.eu

www.treblinka-muzeum.eu

Widok zachodniej („mniej żydowskiej”) strony „obiektu centralnego” projektu Franciszka Duszeńki jako logo Muzeum Walki i Męczeństwa w Treblince wraz z komunikatem „Czynne codziennie (oprócz świąt Bożego Narodzenia i Wielkanocy)" w książce: Co wiemy o Treblince? Stan badań / What do we know about Treblinka? The current state of research, red. Edward Kopówka (Kopówka, 2013, s. 268) (fot. Elżbieta Janicka) 


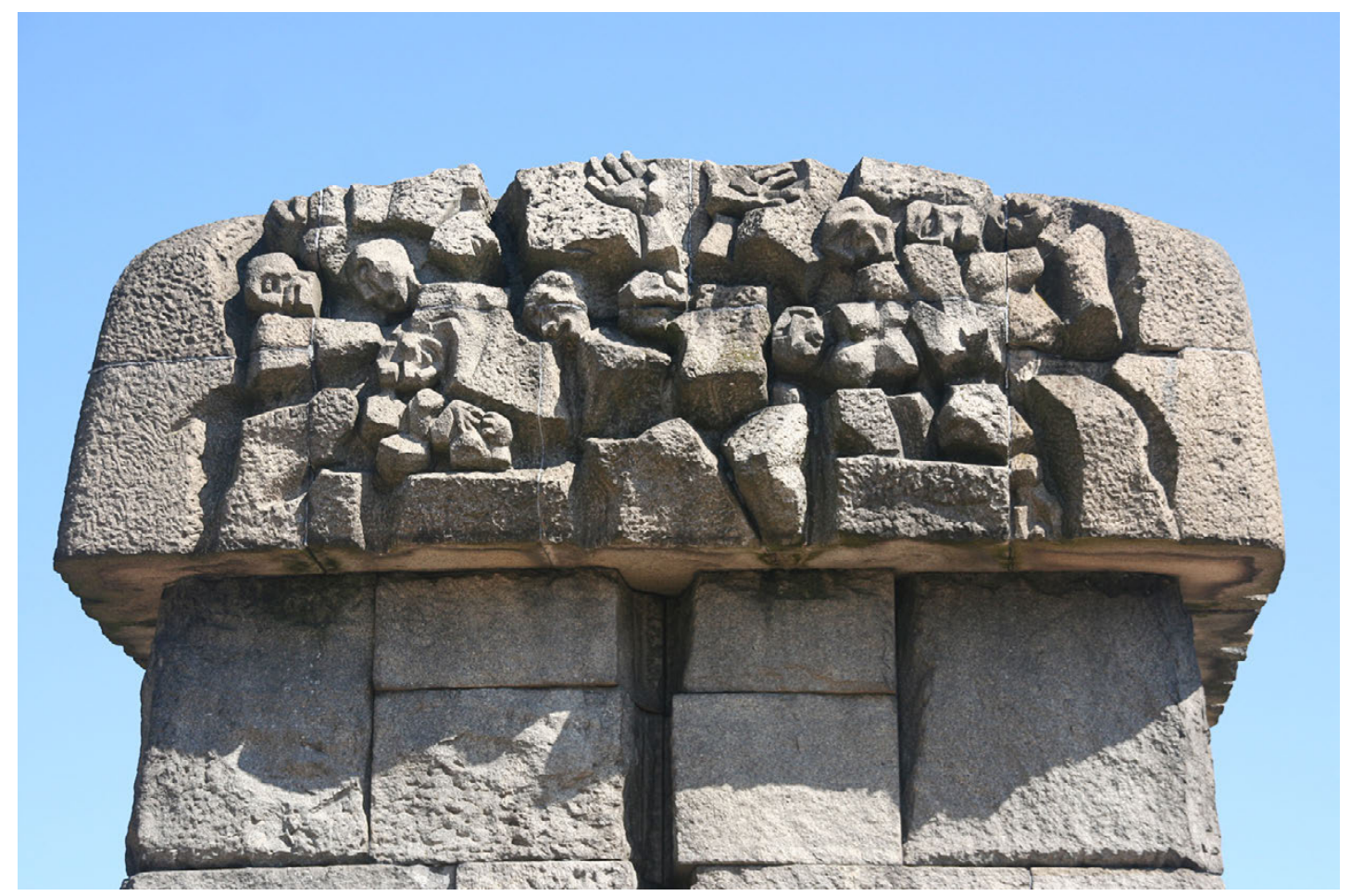

Zachodnia strona kamiennej pokrywy „obiektu centralnego”, widoczna z Czarnej Drogi i byłej rampy pełniącej dzisiaj funkcję głównego wejścia do dawnej strefy śmierci (Totenlager), historycznie zwanej także obozem w obozie - Treblinka II, 8 sierpnia 2020 (fot. Elżbieta Janicka)

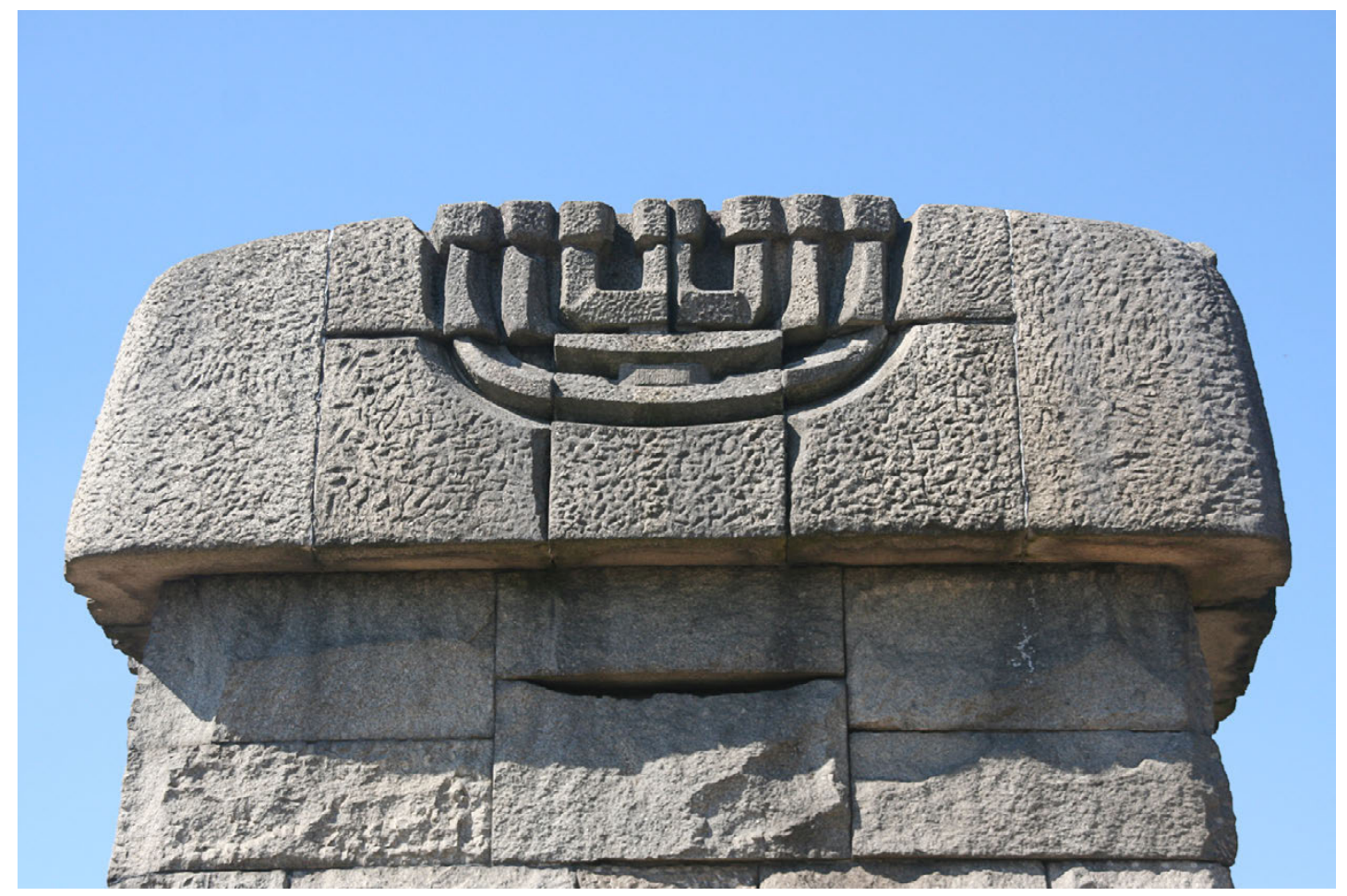

Wschodnia strona kamiennej pokrywy, niewidoczna z Czarnej Drogi i byłej rampy stanowiącej dzisiejsze główne wejście na teren dawnego Totenlager - Treblinka II, 22 sierpnia 2020 (fot. Elżbieta Janicka) 


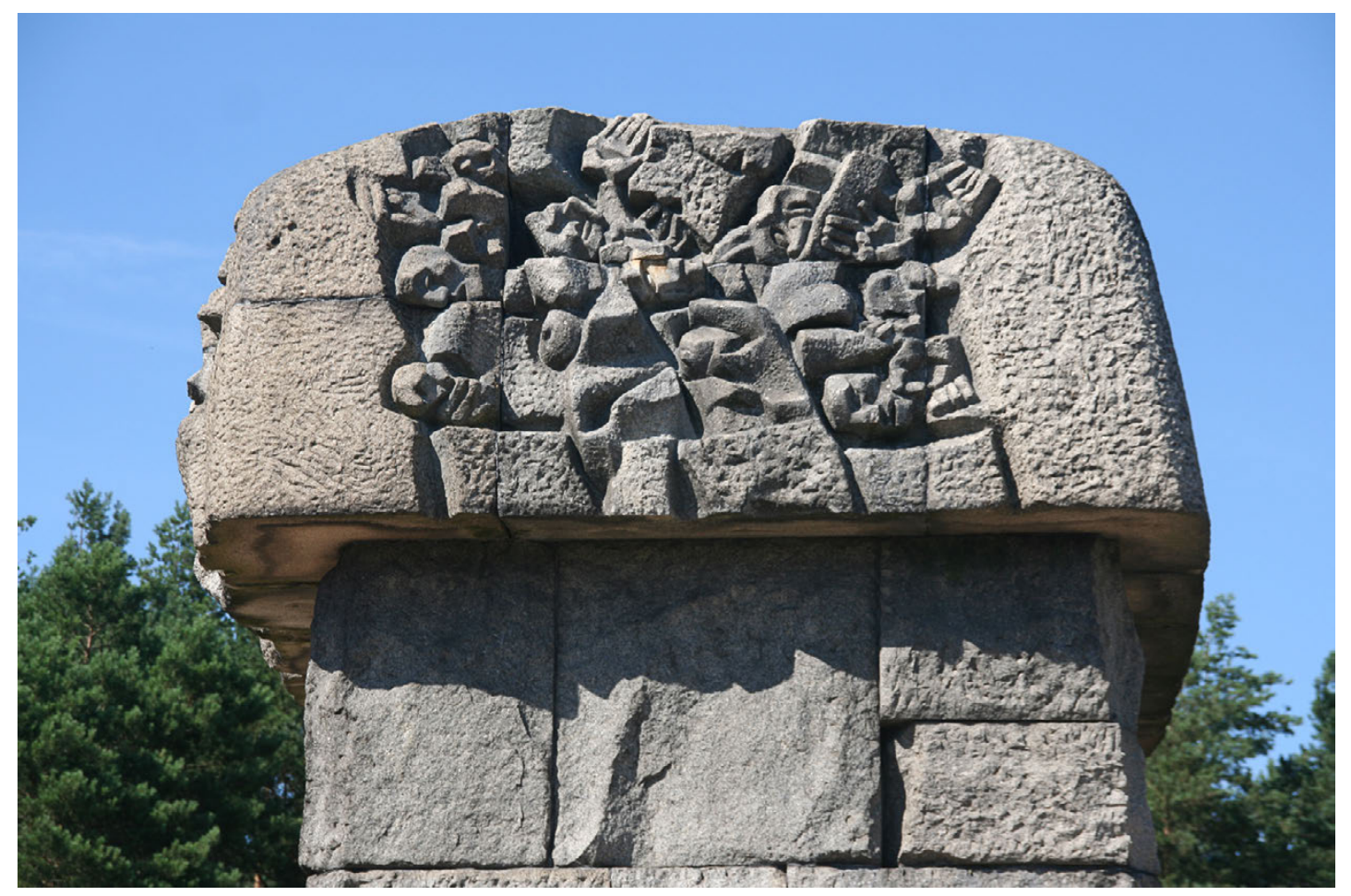

Południowa strona kamiennej pokrywy - Treblinka II, 26 lipca 2020 (fot. Elżbieta Janicka)

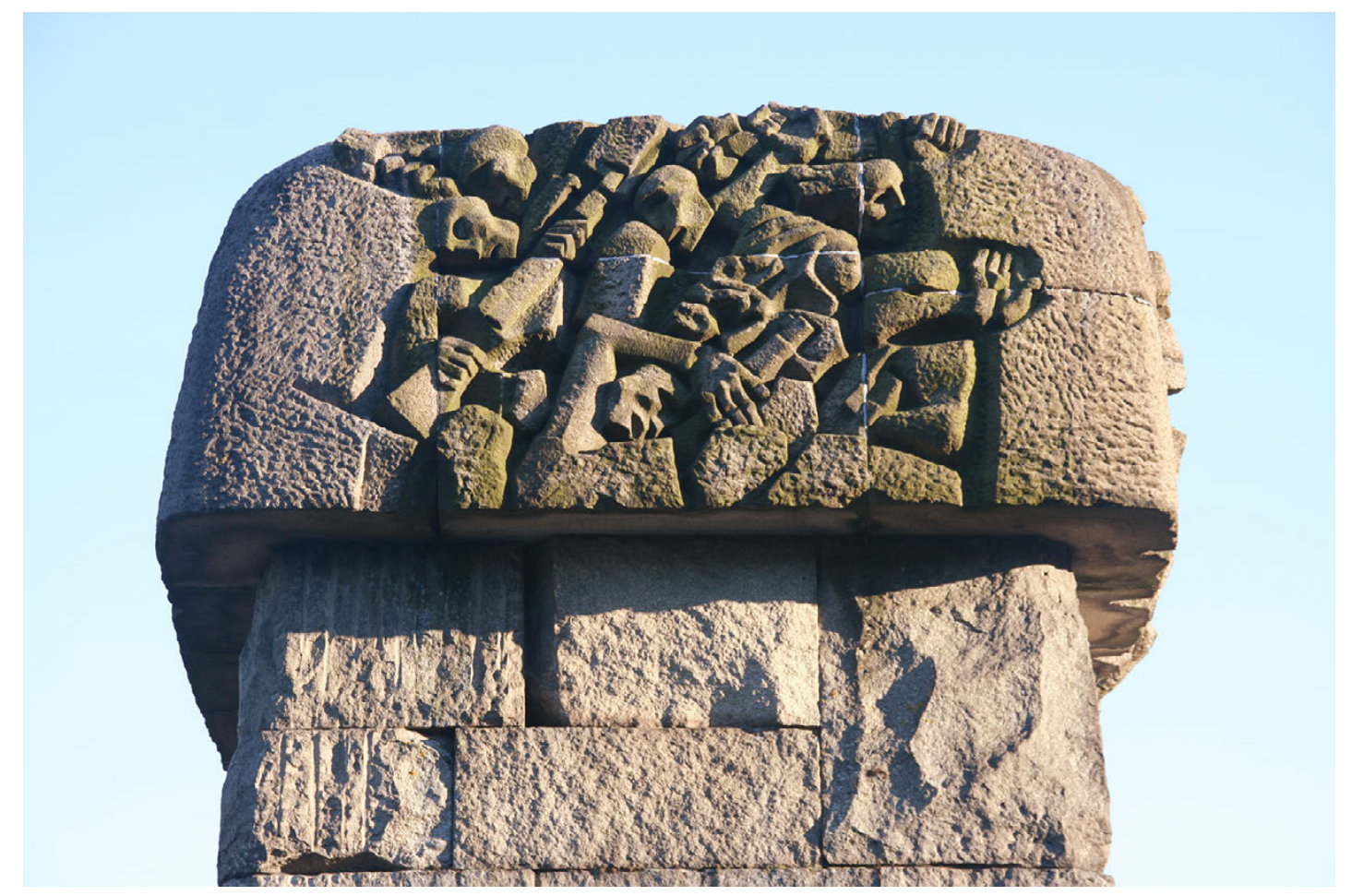

Północna strona kamiennej pokrywy - Treblinka II, 26 lipca 2020 (fot. Elżbieta Janicka) 


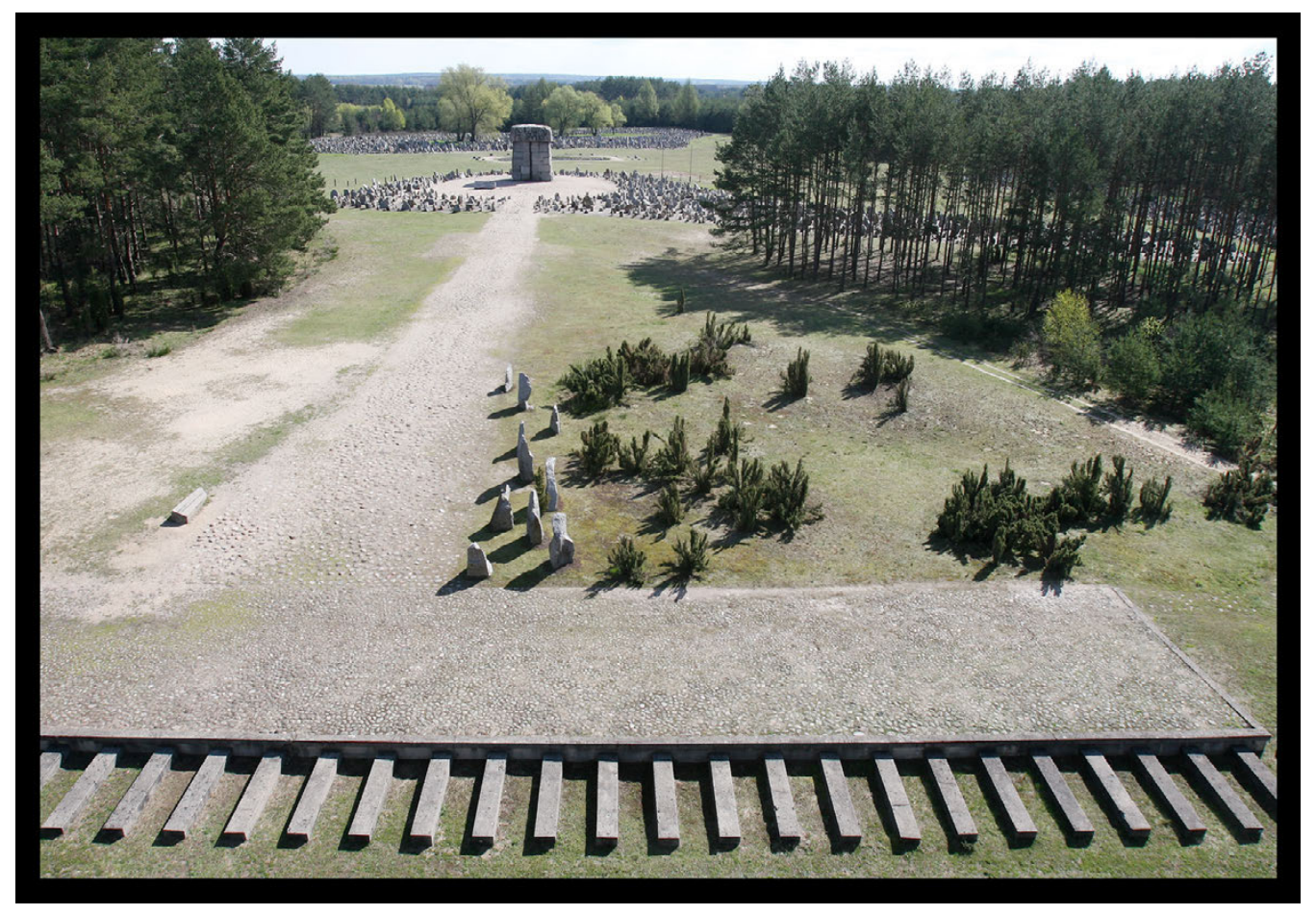

Symboliczne tory kolejowe i rampa wraz z drogą z „kocich Łbów” prowadzącą do „obiektu centralnego”. Dalej w głąb symboliczne krematorium plenerowe. Jałowce widoczne na pierwszym planie po prawej stronie obecnie nie istnieją. Widok w kierunku wschodnim - Treblinka II, 19 kwietnia 2007 (fot. Piotr Tołwiński) (๑ by Piotr Tołwiński, dzięki uprzejmości Autora zdjęcia)

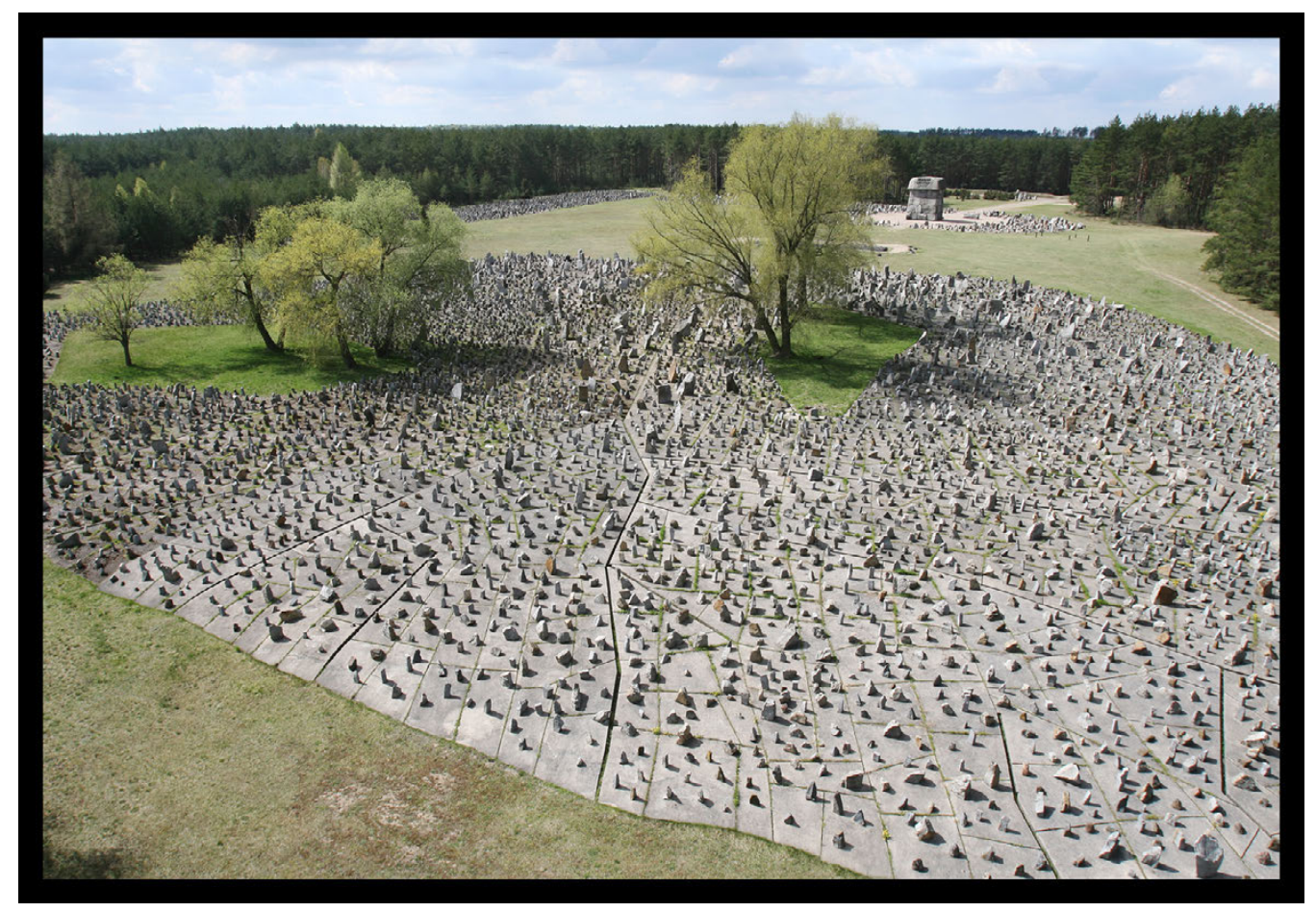

Kamienie - symboliczne macewy - na masowych grobach. Oficjalny tytuł nadany plikowi przez Muzeum Walki i Męczeństwa w Treblince pomijający istnienie betonowych płyt dobrze widocznych z użytej przez fotografa drabiny strażackiej. Widok w kierunku zachodnim - Treblinka II, 19 kwietnia 2007 (fot. Piotr Tołwiński) (@ by Piotr Tołwiński, dzięki uprzejmości Autora zdjęcia ) 


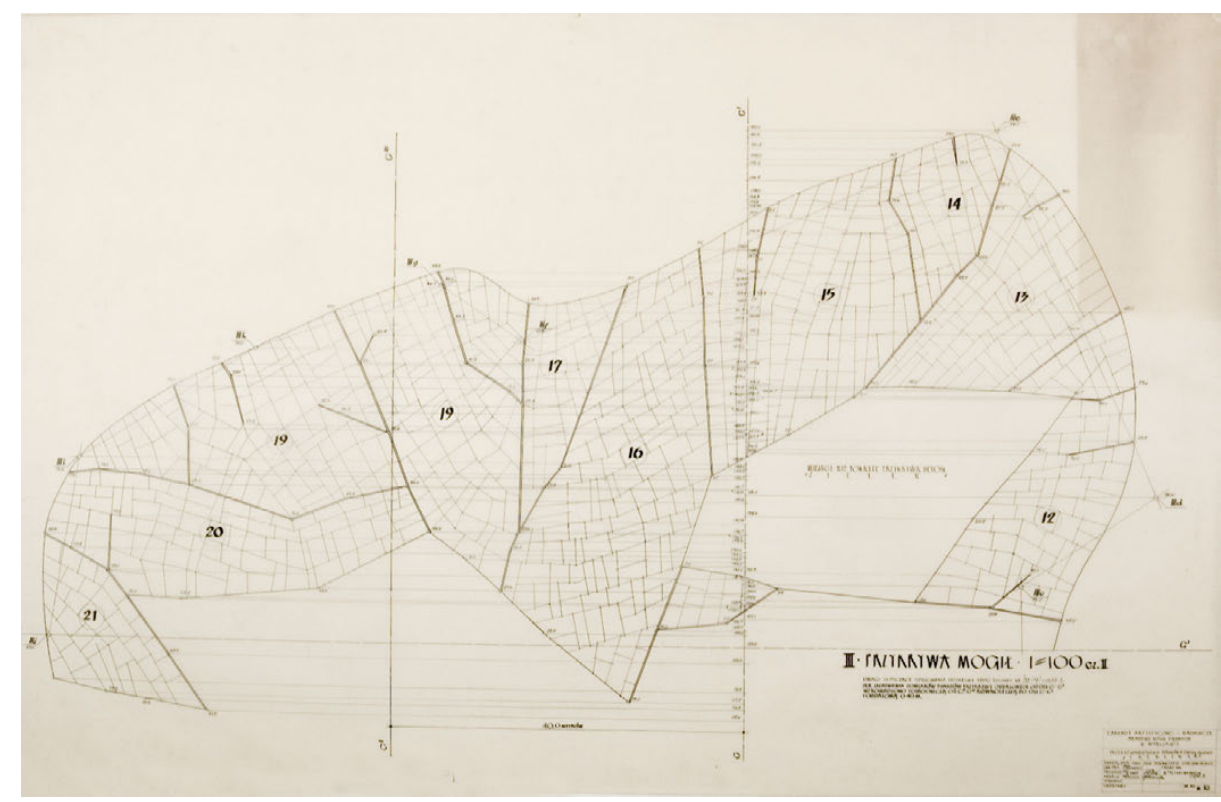

Trzecie skupisko prochów i innych szczątków mieści się we wschodnie części byłego Totenlager. Oś C-C'

odpowiada osi wschód-zachód przechodzące przez środek „pomnika”

III przykrywa mogit, cz. II. Rysunek techniczny betonowych płyt mających pokryć zachodnią część trzeciego skupiska prochów i innych szczątków podzieloną na dziesięć pól. Metryka dokumentu głosi: „Zakłady Artystyczno-Badawcze Akademii Sztuk Pięknych w Warszawie. Projekt upamiętnienia terenów b. obozu zagłady «Treblinka». Gen. proj. Franciszek Strynkiewicz. Projektow. Adam Haupt. Kreślit Henryk Kitowski. 30 grudnia 1961” (dokument z archiwum Adama Haupta, cyt. za: Radecka, 2011)

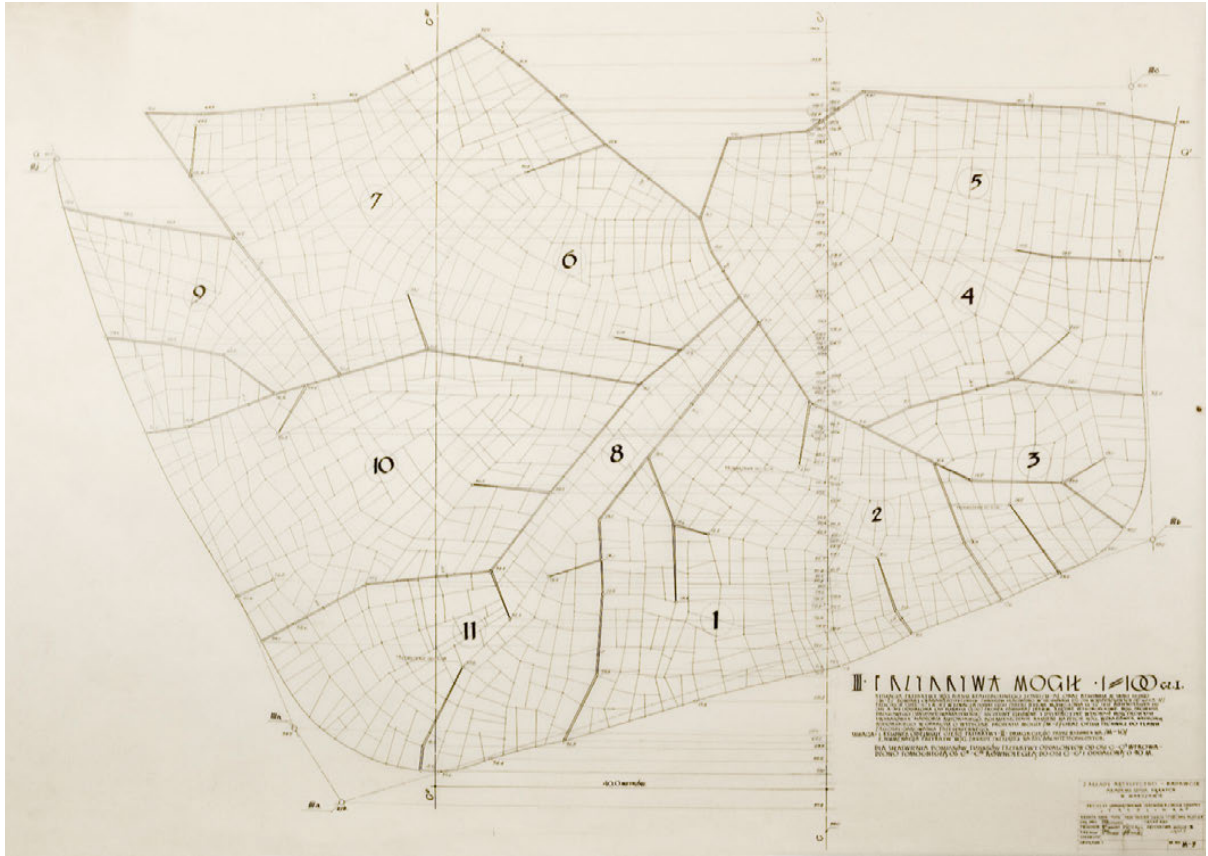

Trzecie skupisko prochów i innych szczątków mieści się we wschodniej części byłego Totenlager. Oś C-C'

odpowiada osi wschód-zachód przechodzace przez środek „pomnika”

III przykrywa mogit, cz. I. Rysunek techniczny betonowych płyt mających pokryć wschodnią część trzeciego skupiska prochów i innych szczątków podzieloną na jedenaście pól. Metryka dokumentu głosi: „Zakłady Artystyczno-Badawcze Akademii Sztuk Pięknych w Warszawie. Projekt upamiętnienia terenów b. obozu zagłady «Treblinka». Gen. proj. Franciszek Strynkiewicz. Projektow. Adam Haupt. Kreślił Henryk Kitowski. 30 grudnia 1961" (dokument z archiwum Adama Haupta, cyt. za: Radecka, 2011) 


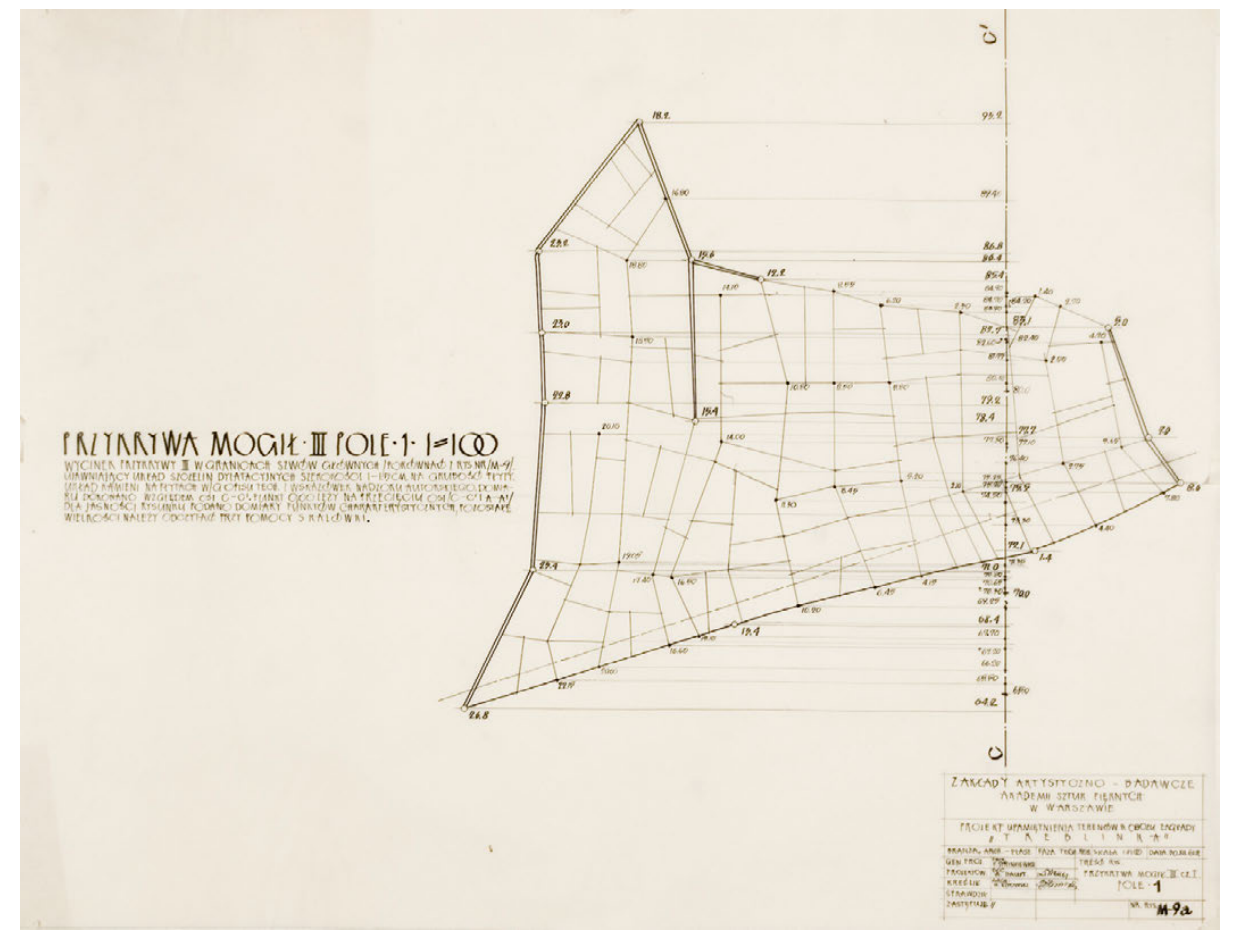

Przykrywa mogit III, pole 1. Metryka dokumentu głosi: „Zakłady Artystyczno-Badawcze Akademii Sztuk Pięknych w Warszawie. Projekt upamiętnienia terenów b. obozu zagłady «Treblinka». Gen. proj. Franciszek Strynkiewicz. Projektow. Adam Haupt. Kreślit Henryk Kitowski. 30 grudnia 1961" (dokument z archiwum Adama Haupta, cyt. za: Radecka, 2011)

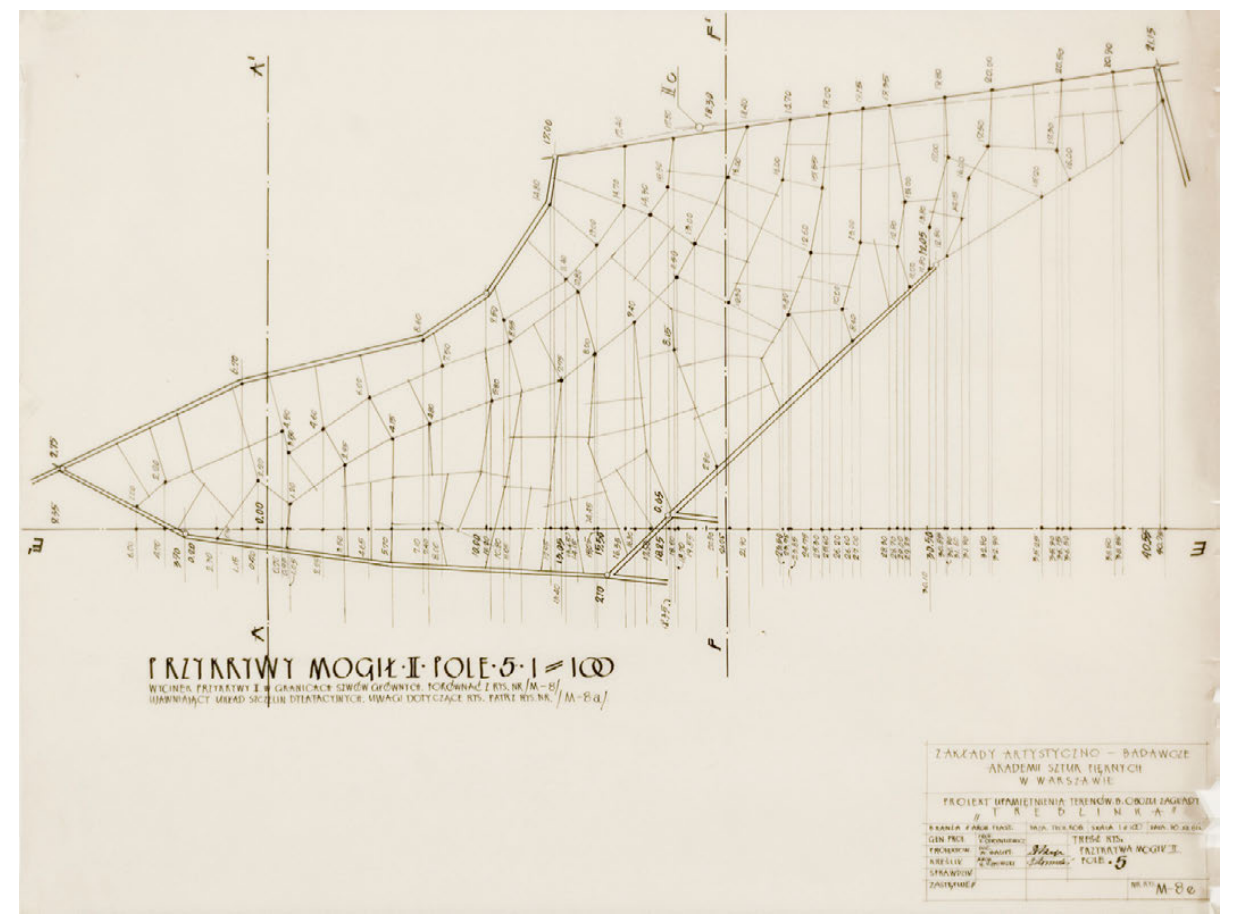

Drugie skupisko prochów i innych szczątków mieści się w południowe części byłego Totenlager. Os A-A' odpowiada osi północpotudnie przechodzącej przez środek „pomnika”

Przykrywa mogit II, pole 5. Metryka dokumentu głosi: „Zakłady Artystyczno-Badawcze Akademii Sztuk Pięknych w Warszawie. Projekt upamiętnienia terenów b. obozu zagłady «Treblinka». Gen. proj. Franciszek Strynkiewicz. Projektow. Adam Haupt. Kreślił Henryk Kitowski. 30 grudnia 1961" (dokument z archiwum Adama Haupta, cyt. za: Radecka, 2011) 


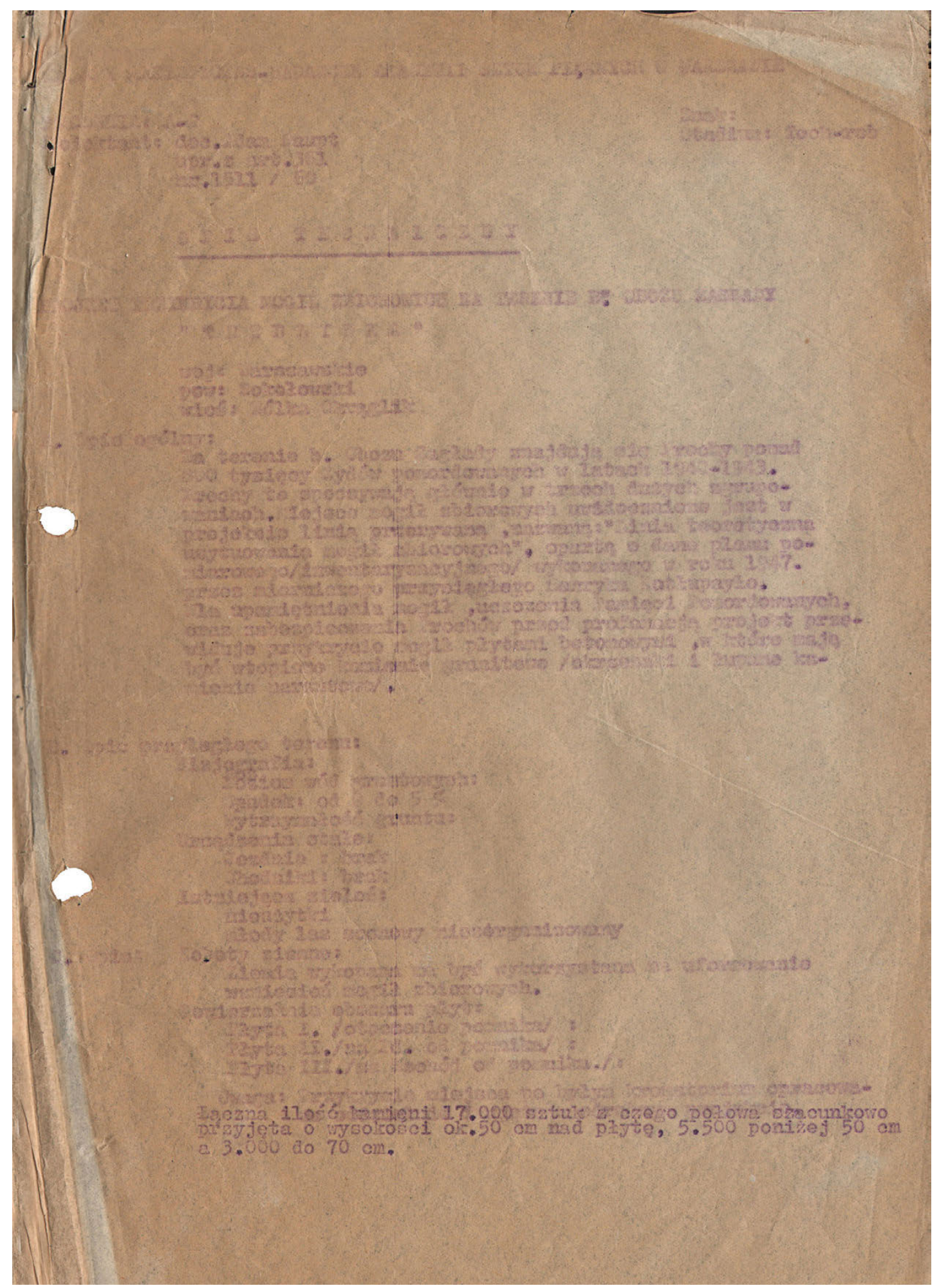

Opis techniczny. Projekt przykrycia mogił zbiorowych na terenie byłego obozu zagłady "Treblinka” autorstwa Adama Haupta (strona 1) (niedatowany dokument z archiwum Adama Haupta, cyt. za: Radecka, 2011) 


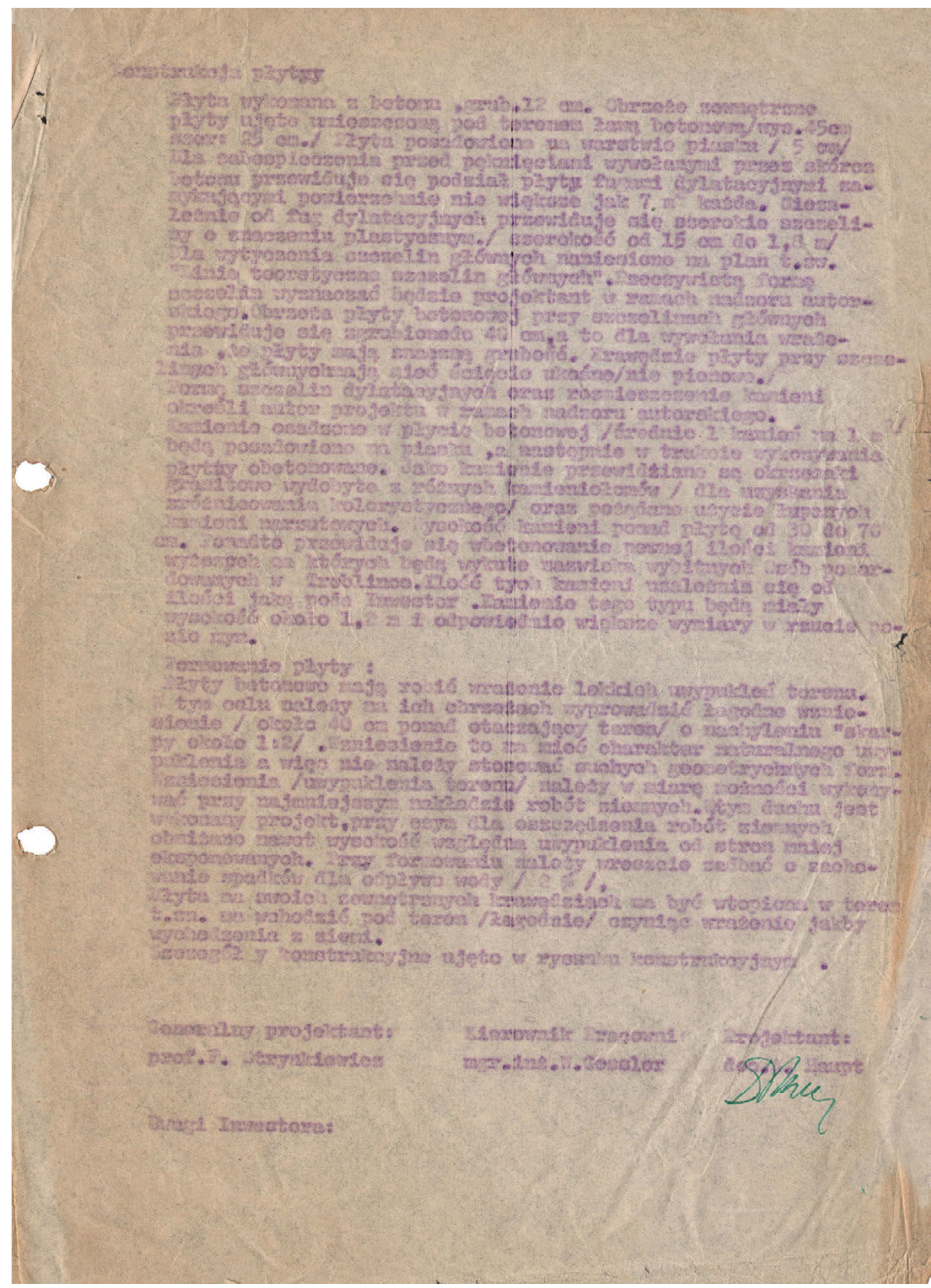

Opis techniczny. Projekt przykrycia mogit zbiorowych na terenie byłego obozu zagłady "Treblinka” autorstwa Adama Haupta (strona 2) (niedatowany dokument z archiwum Adama Haupta, cyt. za: Radecka, 2011)

Haupt zastrzega, że „nie należy stosować suchych geometrycznych form”, co jaskrawo kontrastuje na przykład z logiką berlińskiego Pomnika Pomordowanych Żydów Europy projektu Petera Eisenmana 


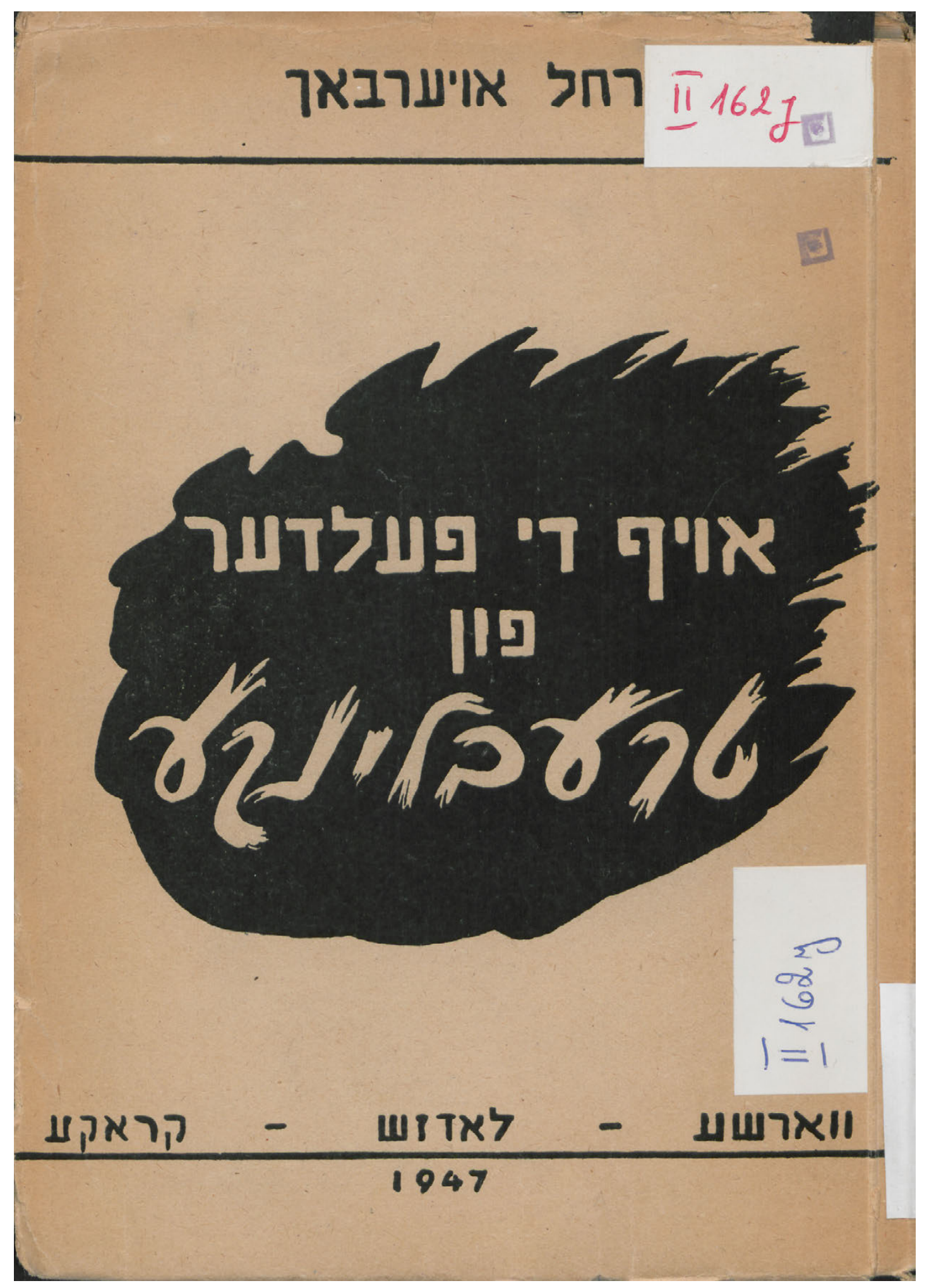

Okładka książki Racheli Auerbach Ojf di felder fun Treblinke [Na polach Treblinki] z biblioteki Żydowskiego Instytutu Historycznego im. Emanuela Ringelbluma w Warszawie. Napis na dole głosi: Warsze, Lodż, Kroke 1947 (fot. Elżbieta Janicka) 


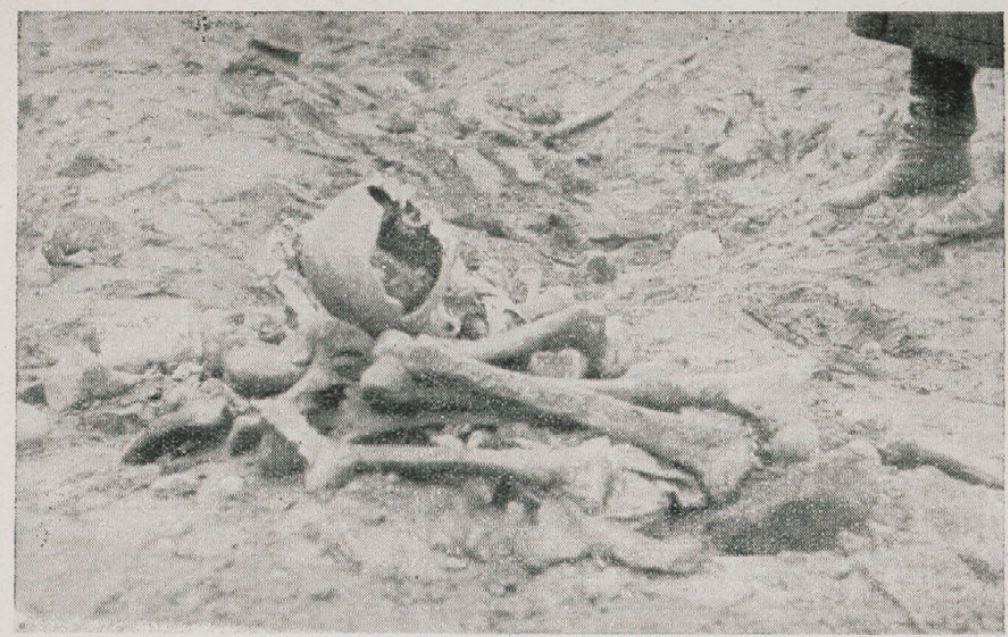

5. טרטבלינקע: קופע מענטשלעכע ביינער

Co znajduje się pod betonem. Nienumerowana karta z fotografią autorstwa Jakuba Byka z książki Racheli Auerbach Ojf di felder fun Treblinke spomiędzy stron 16 i 17 (z biblioteki Żydowskiego Instytutu Historycznego im. Emanuela Ringelbluma). Podpis w jidysz głosi: „Treblinka: sterta ludzkich kości” (tłumaczenie Karolina Szymaniak) (fot. Elżbieta Janicka)

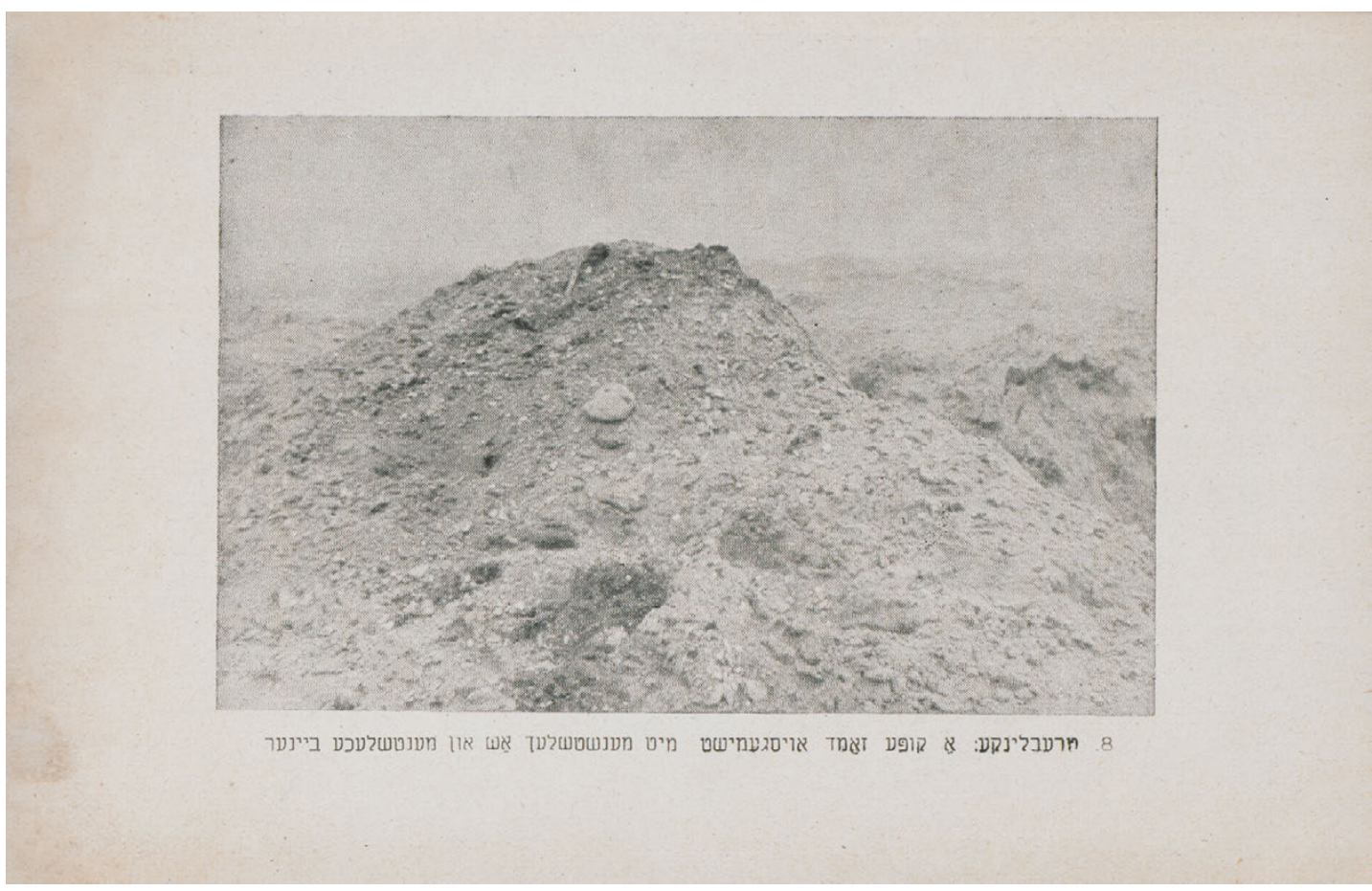

Co znajduje się pod betonem. Nienumerowana karta z fotografią autorstwa Jakuba Byka z książki Racheli Auerbach Ojf di felder fun Treblinke spomiędzy stron 80 i 81 (z biblioteki Żydowskiego Instytutu Historycznego im. Emanuela Ringelbluma). Podpis w jidysz głosi: „Góra piasku zmieszanego z ludzkimi prochami i kośćmi” (tłumaczenie Karolina Szymaniak) (fot. Elżbieta Janicka) 
wego Mesjasza, na czele. Jeśli chciałoby się całą tę kakofonię zinterpretować w spójny sposób, wychodzi z tego oś odkupienia wiodąca od destrukcji do rekonstrukcji. Teologiczne i ideologiczne zawłaszczenie. Jednym słowem, racjonalizacja Zagłady ${ }^{19}$.

$\mathrm{Na}$ odnotowanie zasługuje przestrzenna przenikalność kommemoratywnego całokształtu. Teren został wyraźnie oznaczony, jednakże zwierzęta i ludzie mogą swobodnie pojawiać się i krążyć w jego obrębie. Upamiętnienie Treblinki jest przeciwieństwem szczelnie ogrodzonego i odgrodzonego (jeśli nie: zaduszonego betonem oraz innymi materiałami) terenu byłego obozu zagłady w Bełżcu. Owszem, Haupt, Duszeńko i Strynkiewicz zasugerowali kierunki poruszania się, lecz każdy - czy to zwierzę, czy też człowiek - jest władny obrać własną drogę. W praktyce odwiedzający rzadko oddalają się od „pomnika”, który - wraz z makietą paleniska - zazwyczaj im wystarcza. W tym sensie „obiekt centralny” pełni funkcję odgromnika i izolatora również w drugą stronę. Zaspokaja i uspokaja żywych. Przynajmniej większość. Pozwala mi to pracować bez przeszkód nawet w szczycie turystycznego sezonu.

Beton i grunt są Realnym, rzeczą samą w sobie. Bez symbolizacji innej niż - sporządzone w latach sześćdziesiątych i niedawno odkryte - obrysy geodezyjne, obliczenia i rysunki techniczne każdego bez wyjątku centymetra kwadratowego betonowych płyt oraz szczelin zaprojektowanych przez Adama Haupta. Przewidziane do odprowadzania wody i mające pozwolić „pracować” prochom oraz betonowi szczeliny z powodzeniem pełnią dzisiaj również funkcję korytarzy dla jaszczurek. Przekonana, że beton został wylany stosunkowo dowolnie, na oko, nie zdawałam sobie sprawy, że za każdym ich zakrętem i przecięciem, każdym kątem i krzywizną, stała myśl inżynieryjno-techniczna i osoba projektanta. Czy Adam Haupt był szaleńcem? Był architektem. Projektował wnętrza okrętów i formy przemysłowe służące żywym. Tu pracował w służbie martwych, których losu udało mu się samemu uniknąć. Lata później wspominał w sposób chaotyczny i niegramatyczny: „Rozgrzebana była tu i tam ziemia, kości leżały na wierzchu, trzeba było po pierwsze - zabezpieczyć, żeby tego nie profanowali, bo przecież to są święte groby. Po drugie, żeby upamiętnić tak, aby nic nie było w stanie ruszyć, żeby to było jak najprostszymi środkami, uniknąć wszelkiego popisywania się, bo to by było nieprzyzwoite w stosunku do tego, co tam się stało” (cyt. za: Taborska, 2002). „Aby nic nie było w stanie ruszyć”, gdzie spektrum znaczeniowe „ruszyć” rozciąga się od „przemieścić” do „pogwałcić”.

Przy wielu okazjach Haupt podkreślał prostotę projektu dla Treblinki: „Naszą wytyczną w pracy była jak największa powściągliwość, unikanie wszelkiego efekciarstwa. [...] Postanowiliśmy stosować jak najprostsze materiały. Kamień rwany, nie obrabiany, surowy beton, na którym widoczne będą odbicia szalowania" (Haupt, 1961, s. 3). Istotnie, rezultat wygląda surowo i prosto. Betonowe płyty zaś „nie wyglądają” wręcz wcale w tym sensie, że są rzadko zauważane i jeszcze rzadziej opatrywane komentarzem. Narracyjny dokument zatytułowany Spis techniczny oraz dziesiątki kreślarskich kalek,

19 Żadne z autorów zajmujących się upamiętnianiem Treblinki nie odnosi się do kwestii, które tu poruszam (zob. Grzesiuk-Olszewska, 1995; Zawadka, 2015; Taborska, 2003, ss. 56-61). 
które poświęcił im Haupt, nie były przeznaczone do oglądania. Odkrycie tych materiałów przez Katarzynę Radecką było dla mnie całkowitym zaskoczeniem. Rodzajem wstrząsu może nawet. Z powodu ogromu wysiłku, jaki sobą przedstawiały. Jak gdyby Haupt zawart w ich chirurgicznej precyzji niepohamowany impet i rozsadzające go emocje. Jak gdyby stanowiły dowód szaleństwa zakamuflowanego pozornie bezosobowym rygorem i dyscypliną. Na podobieństwo utworu poezji konkretnej. Concrete poetry.

\section{Heimat}

\section{Archeologia projektu}

Zielnik poprzedzało Miejsce nieparzyste (2003-2004), praca zawierająca trzy elementy. Na pierwszy z nich składa się sześć fotografii powietrza nad byłymi niemieckimi nazistowskimi obozami zagłady: Bełżec, Kulmhof am Ner (Chełmno nad Nerem), Majdanek, Auschwitz II Birkenau (Oświęcim-Brzezinka), Sobibór, Treblinka II. Wszystkie one pozostały w granicach Polski, mimo iż w konsekwencji drugiej wojny światowej kraj został znacząco przesunięty na zachód kosztem Niemiec. Lokalizacja stanowiła ważny element wojennego kontekstu ich funkcjonowania oraz czynnik rozstrzygający o ich powojennym losie. Drugą składową Miejsca nieparzystego jest trzynaście nagrań powietrza nad wymienionymi obozami. Tak. To powietrze chciałam zarejestrować. Dźwięk był drugorzędny, wtórny. Pierwszorzędne i pierwotne było powietrze, które umożliwia dźwiękowi zaistnienie, gdyż nie jest możliwy dźwięk w próżni. Stawką była materialność powietrza. Podobnie jak w wypadku światła, z którego podwójnej natury - dualizmu korpuskularno-falowego - liczyła się dla mnie jego materialność. Trzecim elementem pracy jest tytuł nawiązujący do pieczątki: „Miejsce w ławkach nieparzystych”. Administracja Uniwersytetu Warszawskiego znakowała nią indeksy żydowskich studentów. Pieczątka ta - w moim odczuciu - stanowi emblemat antysemickich procedur i, szerzej, antysemickiej polityki przedwojennego państwa polskiego.

Miejscu nieparzystemu towarzyszył tekst Hortus Judeorum (Janicka, 2006). Oryginalnie hortus iudaeorum - po łacinie: 'ogród żydowski' - to miano, jakim w chrześcijańskiej Europie określano żydowski cmentarz, będący najczęściej jedynym terenem zielonym, gdzie Żydzi mogli przebywać bez ograniczeń i czuć się bezpiecznie. Postanowiłam przedefiniować kategorię hortus iudaeorum (zob. Bal, 2002) i użyć jej - w uproszczonej ortografii charakterystycznej dla sarmackiej łaciny polskiej szlachty - na oznaczenie krajobrazu powojennej Polski jako żydowskiego cmentarza czy raczej sarkofagu, który bezpośrednio zaabsorbował żydowskie zwłoki i inne szczątki. Popioły z Auschwitz były wysypywane do Soły w miejscu, gdzie wpada ona do Wisły. Popioły z Sobiboru trafiały do Bugu. Popioły z Kulmhof am Ner natomiast - do Warty. Każda z trzech rzek - Wisła, Bug i Warta - przemierza wzdłuż cały kraj. Wszelako Żydzi zagazowani w niemieckich 
nazistowskich obozach zagłady nie są jedynymi, którzy nie mają grobów. Ofiary polskiego polowania na Żydów nie mają ich także. Podobnie jak Żydzi już wcześniej zamordowani przez Niemców lub Polaków - czy to cywilnych, czy umundurowanych. Mimo licznych powojennych ekshumacji leżą oni przeważnie zakopani w nieoznaczonych miejscach, gdzie zostali pozbawieni życia: przy drogach, przy torze kolejowym, na polach, na łąkach, w lasach, wśród padłych zwierząt, w sadach, w przydomowych ogródkach. Nie sposób wyodrębnić tego terytorium.

Hortus Judeorum podejmował sprawę polskiego antysemityzmu i jego zbrodniczych, morderczych konsekwencji. Podejmował sprawę polskiego imaginarium antysemickiego i jego organicznej topiki wraz z kategorią tak zwanej świętej polskiej ziemi. Imaginarium to zostało wszak przełożone na praktykę i kulminowało w obecnym (d)efekcie specjalnym, którego polska kultura i społeczeństwo nie potrafią nawet przyjąć do wiadomości, nie mówiąc o wzięciu zań odpowiedzialności. Z tą sprawą ściśle wiąże się sprawa żywiołów - ziemi, powietrza, wody, ognia - oraz krajobrazu jako zbiornika z żydowskimi prochami i innymi szczątkami. Odnotowując proces absorpcji, osmozy i recyclingu, poddałam analizie akty oddychania i duszenia się (bycia duszonym), jedzenia oraz trawienia - w ich znaczeniu dosłownym i symbolicznym. Podtytuł tekstu brzmi Refleksje oddechowe i pokarmowo-trawienne na marginesie pracy "Miejsce nieparzyste”.

W tekście wspominałam też o żywności (zwłaszcza żywności ekologicznej) wraz z towarzyszącymi jej fantazjami o czystości i zdrowiu. Odnosiłam się do projektu czystości jako takiego oraz w jego dozwolonej - tolerowanej, jeśli nie pożądanej - formie projektu ekologicznego. Moją intencją nie była kompromitacja tego ostatniego, lecz wskazanie jego niezdekonstruowanych postaci, które mają potencjał podsycania i legitymizowania morderczych przedsięwzięć, jak to miało miejsce w III Rzeszy i może być obserwowane na przykładzie nacjonalistycznej ideologii w ogóle. W dzisiejszej Polsce ekologiczna poetyka niejednokrotnie służy przesłonięciu faktu i konsekwencji mordu na Żydach. Ma to miejsce w powszechnie używanym i spotykanym na co dzień dyskursie postrzeganym jako pozbawiony właściwości. Innymi słowy, całkowicie umykającym percepcji.

Przykład. Rejon Treblinki jest patrolowany przez krowy. Ich wszechobecności w krajobrazie przyświadczają znaki drogowe. Ich mleko trafia do miejscowej mleczarni O.S.M. Kosów. Chodzi o Okręgową Spółdzielnię Mleczarską. I chodzi o Kosów Lacki. Dwa i pót tysiąca Żydów przed wojną. 85\% populacji:

I tutaj - jak we wszystkich miastach i miasteczkach na Podlasiu - Polacy mieli nadzieję, że Hitler ich uszczęśliwi, uwalniając od Żydów. Od Żydów ich uwolnił. Kosowskie męty wzięły nawet znaczący udział w zgładzeniu Żydów. Jak wszędzie, także tutaj rabowali i mordowali swoich żydowskich znajomych, którzy przyszli do nich, żeby się ukryć (Canin, 2018b, s. 233).

Chodzi o Kosów Lacki, sztetl z obrazem El Greca. Chodzi o Kosów Lacki, gdzie znajdowało się jedno z sześciu gett wtórnych - tak zwanych szczątkowych - w dystrykcie warszawskim. Ten sam Kosów Lacki, z którego skradziono macewy do budowy Czarnej 


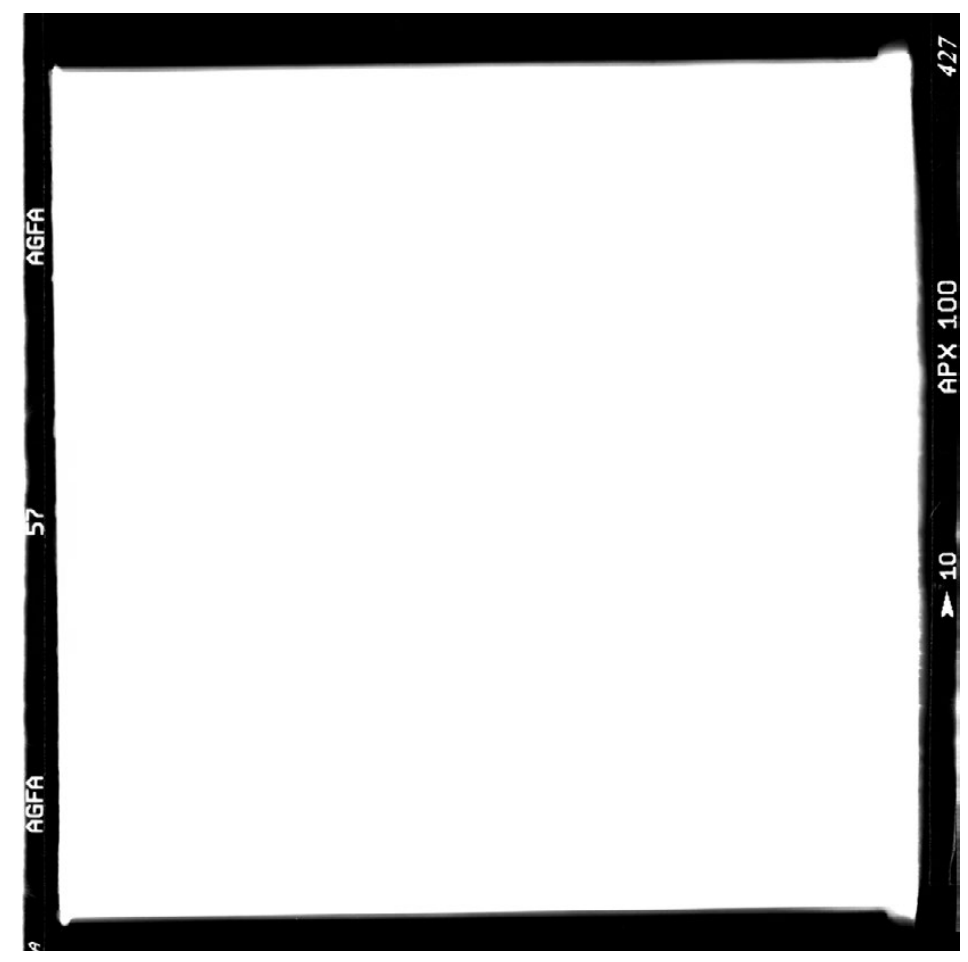

Elżbieta Janicka, Treblinka II

(10 lipca 2004). Praca z cyklu Miejsce nieparzyste (2003-2004)

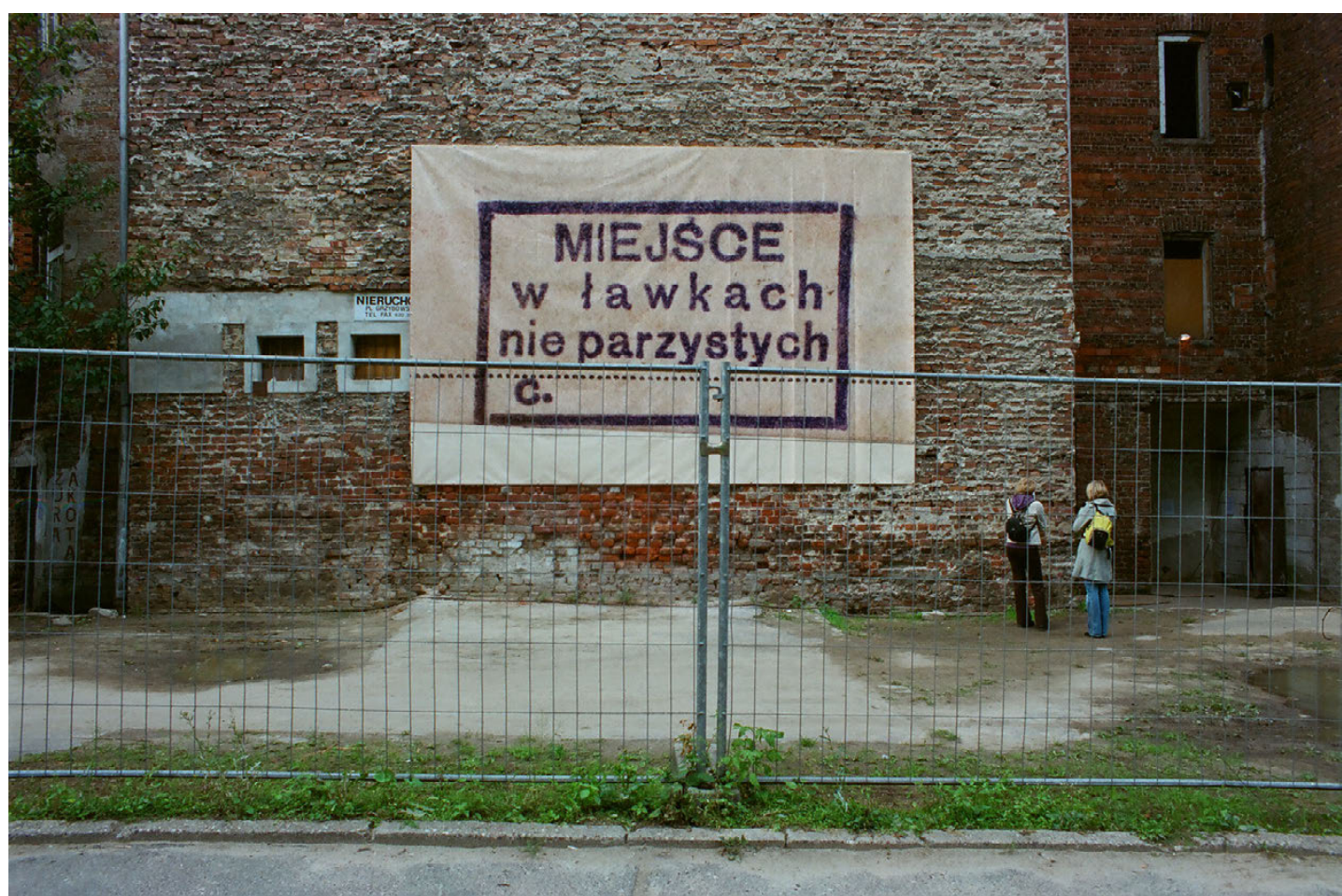

Elżbieta Janicka, Pieczątka (2008). Praca eksponowana na dorocznej wystawie Projekt Próżna zainicjowanej w 2005 roku przez Krystianę Robb-Narbutt i Krystynę Piotrowską, następnie zaś - po śmierci Krystiany Robb-Narbutt w 2006 roku - organizowanej przez Krystynę Piotrowską aż do ostatniej edycji w roku 2012 Warszawa, podwórko przy ulicy Próżnej 7/9,14 września 2008 (fot. Elżbieta Janicka)

Pieczątka pochodzi z indeksu Idess Bieżuńskiej, studentki przedwojennego Uniwersytetu Warszawskiego. Bieżuńska była jedną z tych, którym udało się przeżyć Zagładę. Po wojnie - jako Iza Bieżuńska-Małowist - zasłynęła jako wybitna uczona i wykładowczyni historii na tejże uczelni. Podziękowania za udostępnienie dokumentu zechce przyjąć Włodzimierz Lengauer 


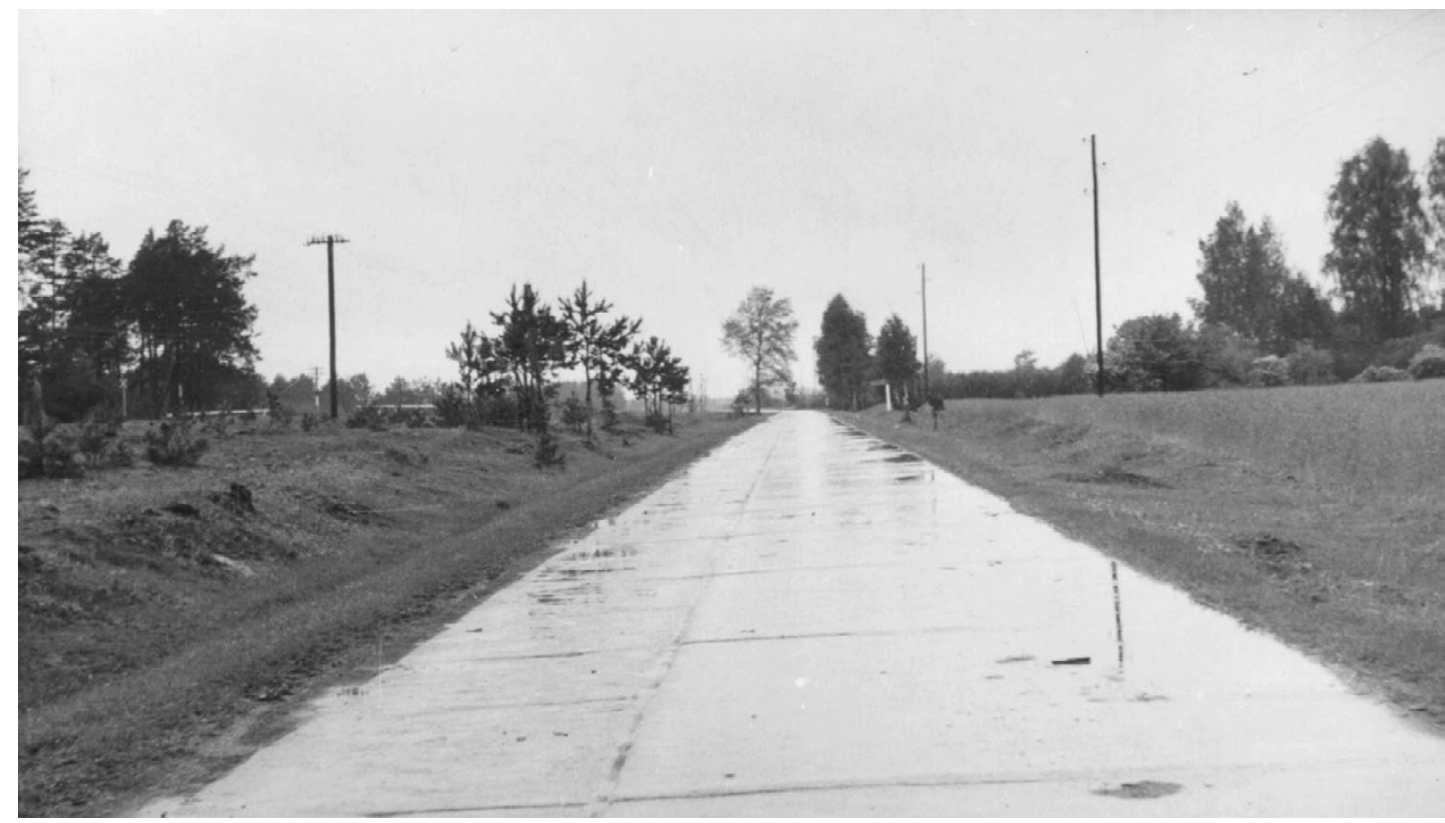

Betonowa droga Małkinia-Kosów Lacki wybudowana przez miejscowych żydowskich robotników przymusowych przed niemiecką inwazją na ZSRR 22 czerwca 1941 roku. Widok w stronę Małkini uchwycony w 1958 roku prawdopodobnie przez Adama Haupta na wysokości leśnej przecinki prowadzącej do byłych obozów. W tle widoczny zakręt, za którym betonowa droga przecinała się z torami kolejowymi, tory kolejowe zaś rozdwajały się na trakcję powszechnie uczęszczaną i bocznicę wiodącą do obu obozów. Bocznica już nie istniała w momencie wykonywania zdjęcia. Regularna trakcja kolejowa została natomiast zdemontowana po upadku Polskiej Rzeczypospolitej Ludowej, który nastąpił w roku 1989. Ten sam los spotkał stację kolejową we wsi Treblinka (fotografia z archiwum Adama Haupta, cyt. za: Radecka, 2011)

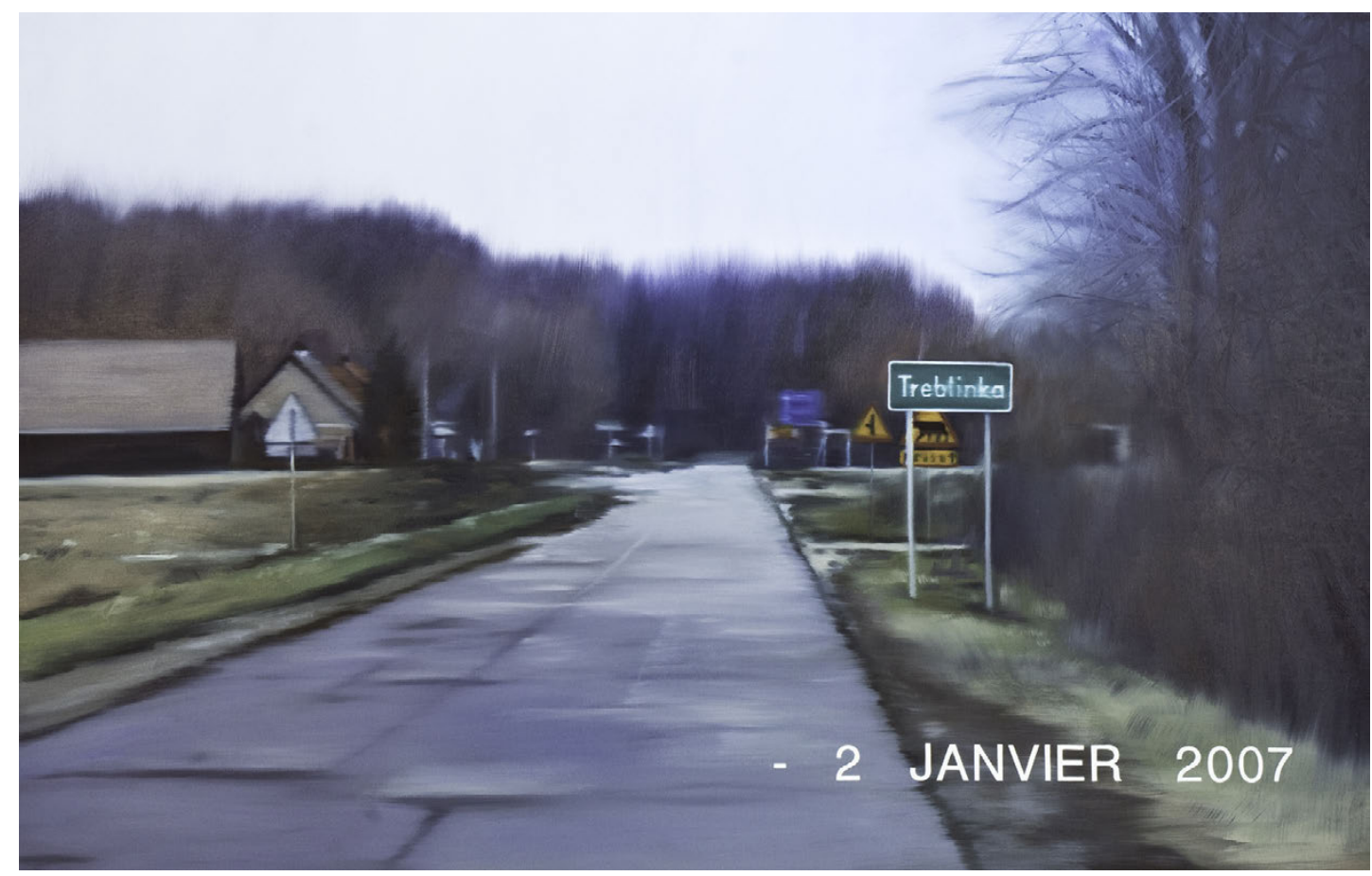

Zofia Lipecka, Environs de Treblinka 2007, olej na płótnie, 130 x 195 cm (๔ by Zofia Lipecka, dzięki uprzejmości Artystki)

Podstawą obrazu Zofii Lipeckiej jest fotografia przedstawiająca widok w stronę Małkini, wykonana przez artystkę 2 stycznia 2007 roku we wsi Treblinka. Drzewa z prawej strony odpowiadają lokalizacji nieistniejącej stacji kolejowej. 


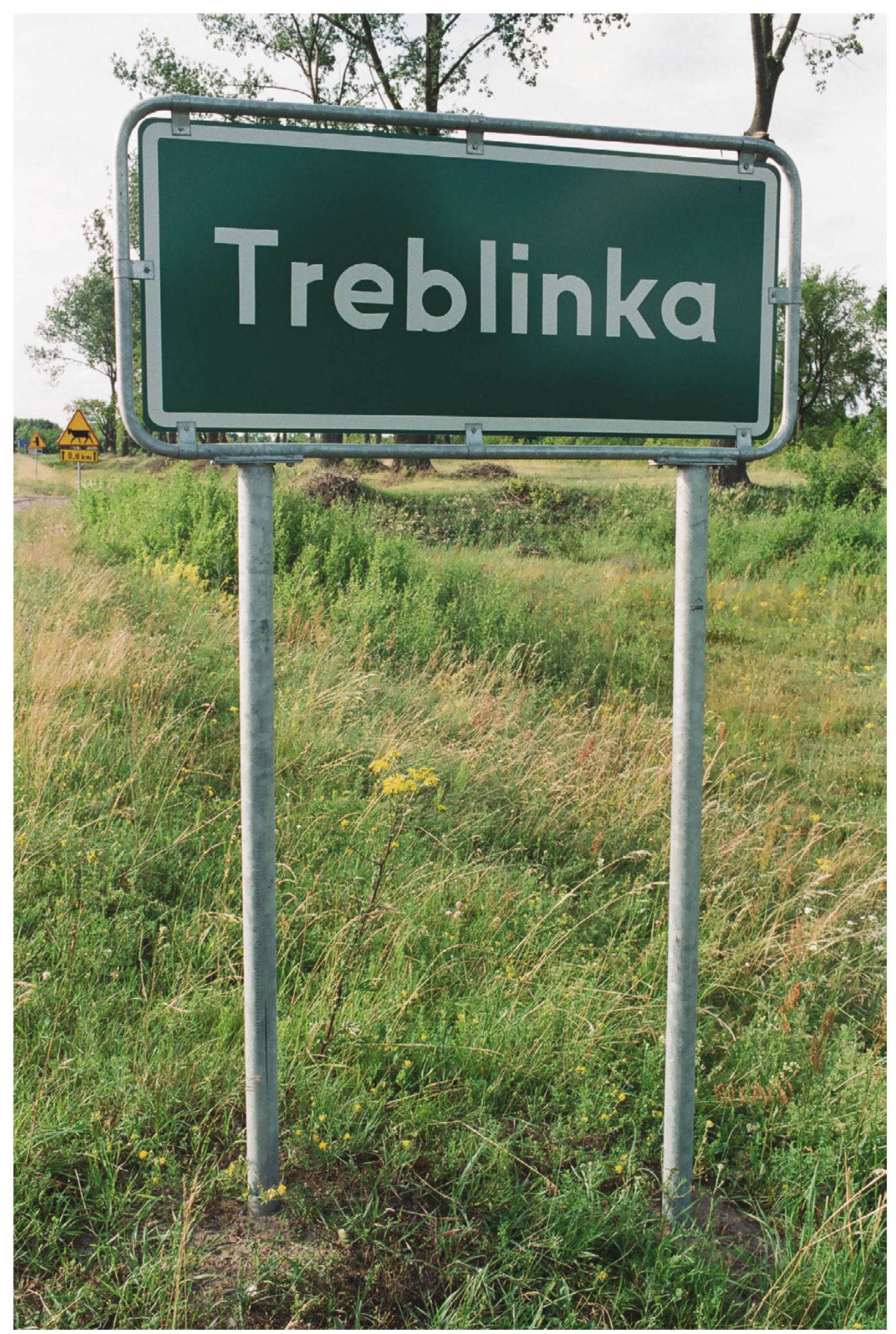

To samo miejsce trzy lata wcześniej (detal). Tablica z nazwą miejscowości na poboczu ze znakiem z krową w tle - Treblinka (wieś), 10 lipca 2004 (fot. Elżbieta Janicka) 


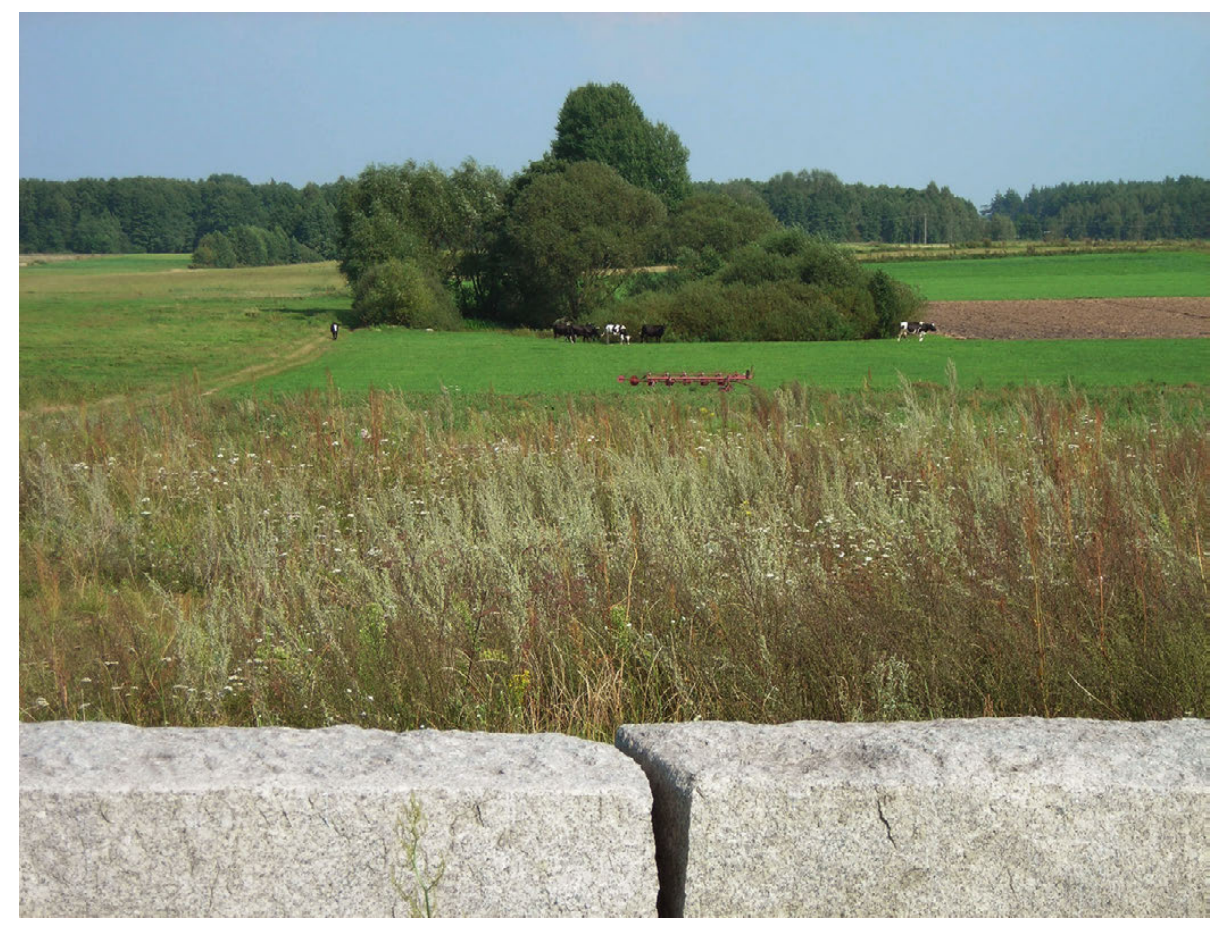

Widok w kierunku wschodnim z wnętrza stodoły Bronisława Śleszyńskiego, w której jedwabieńscy Polacy spalili żywcem jedwabieńskich Żydów 10 lipca 1941 roku. Stodoła i jej okolice stały się żydowskim grobem masowym. Szary granit stanowi część pomnika z 2001 roku autorstwa Ewy Trafnej. Umiejscowienie granitowych bloków odpowiada obrysowi stodoły - Jedwabne, 22 sierpnia 2007 (fot. Elżbieta Janicka)

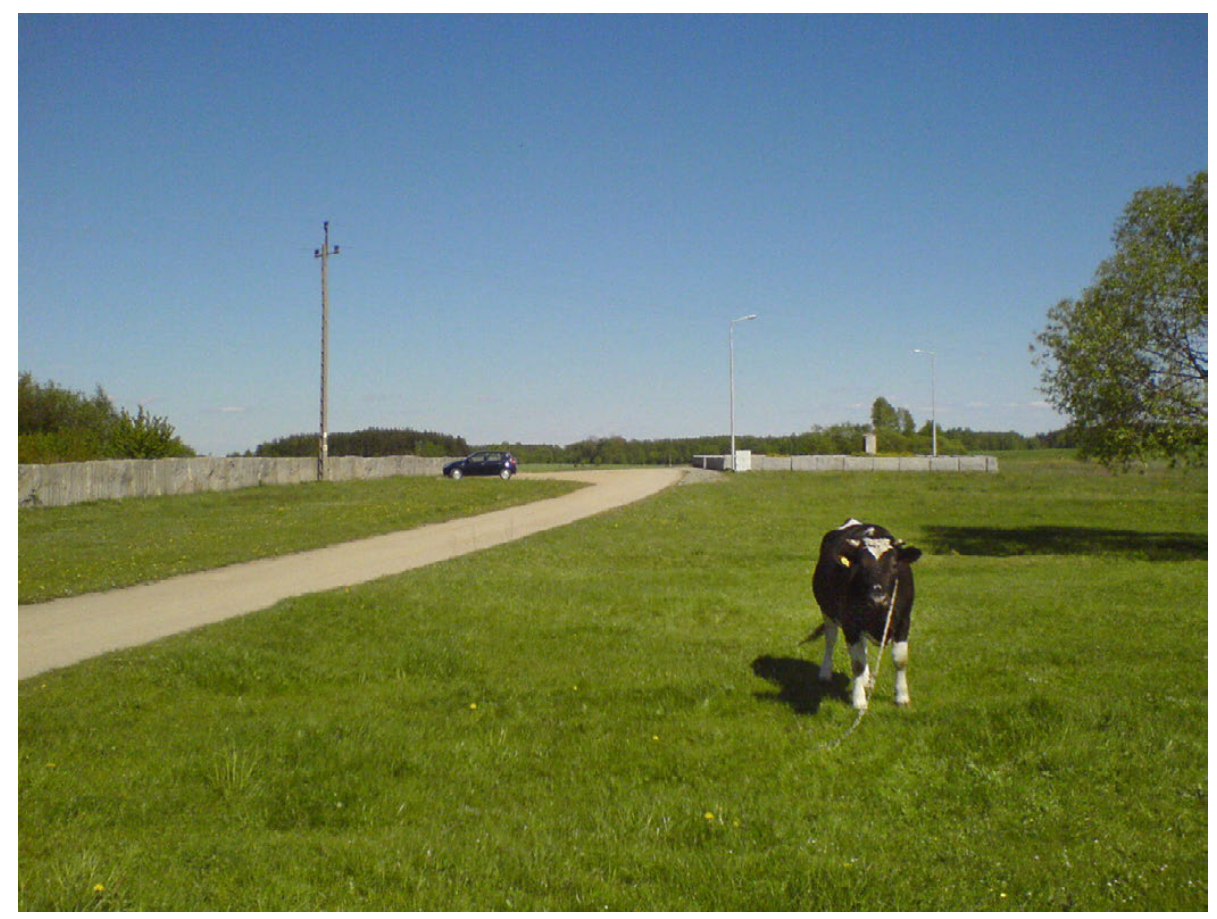

Bloki szarego granitu po prawej stronie drogi to część pomnika z 2001 roku autorstwa Ewy Trafnej. Ich umiejscowienie odpowiada obrysowi stodoły Bronisława Śleszyńskiego. Po lewej stronie drogi zarośnięty cmentarz żydowski doszczętnie obrabowany po drugiej wojnie światowej - Jedwabne, 6 maja 2014 (fot. Henryk Hollender) (๔ by Henryk Hollender, dzięki uprzejmości Autora zdjęcia) 


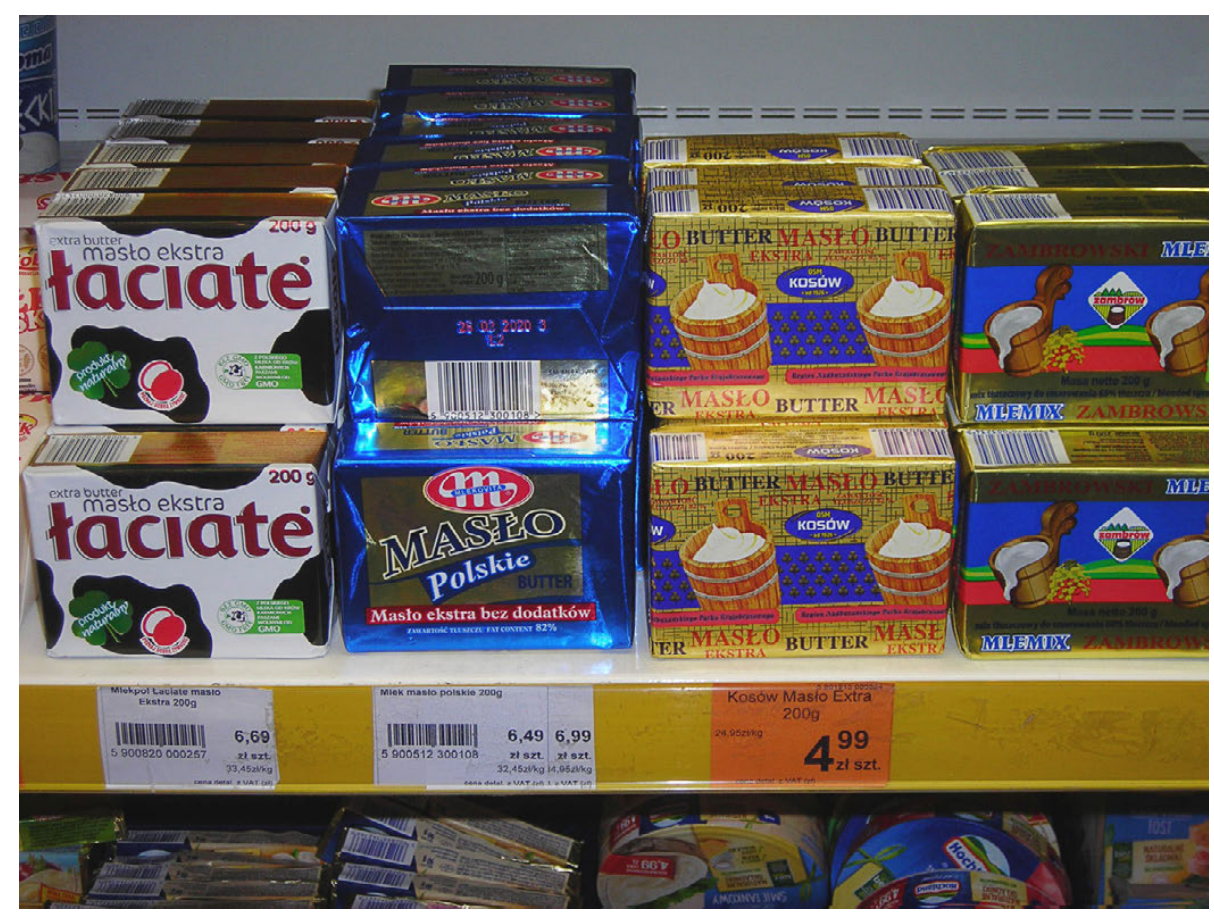

Masło z okolic Treblinki i Jedwabnego w warszawskim sklepie spożywczym - 5 stycznia 2020 (fot. Elżbieta Janicka)

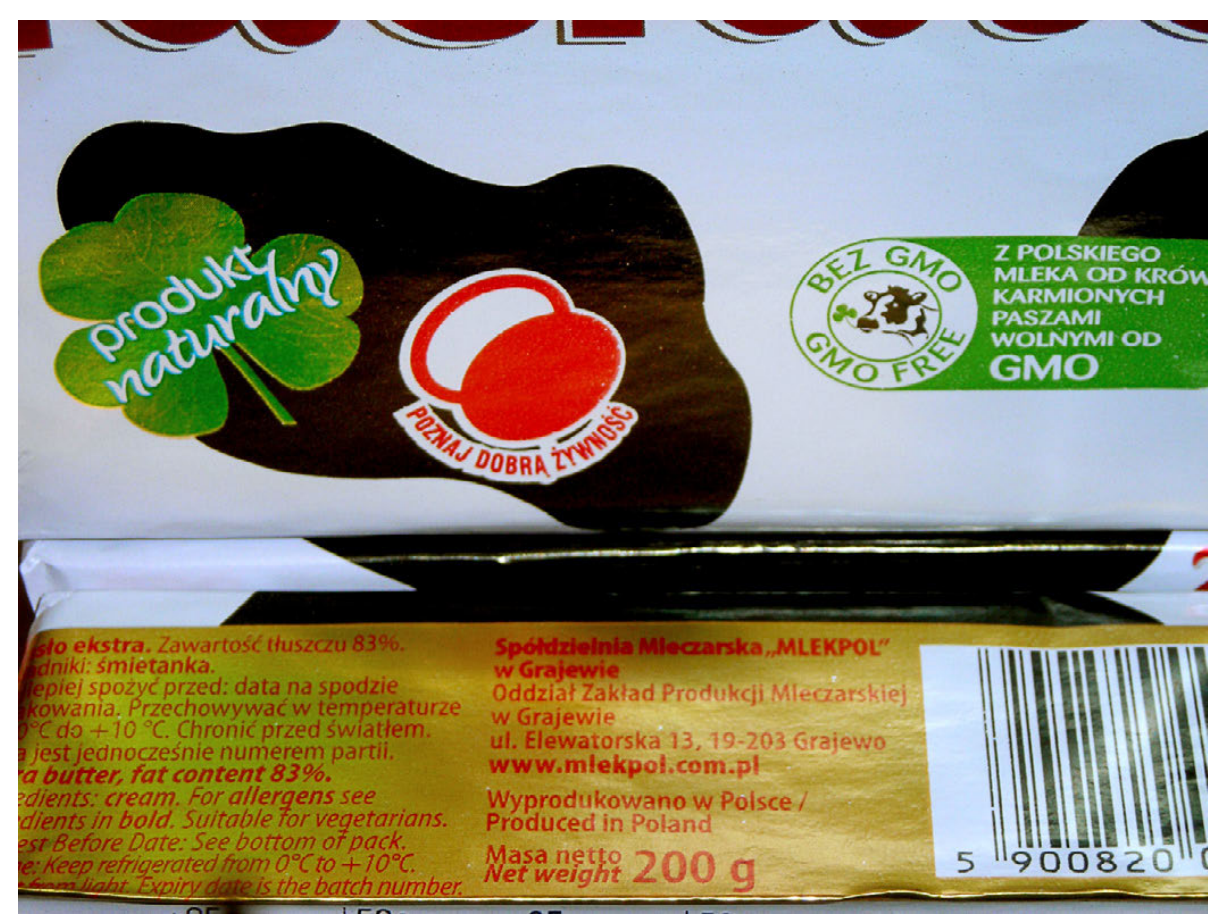

„Masło ekstra łaciate” ze Spółdzielni Mleczarskiej MLEKPOL w Grajewie. „Poznaj dobrą żywność: naturalny produkt z polskiego mleka od krów karmionych paszami wolnymi od GMO” w warszawskim sklepie spożywczym - 5 stycznia 2020 (fot. Elżbieta Janicka)

Powiat grajewski obejmuje wsie i miasteczka takie, jak Goniądz, Grajewo, Jedwabne, Kolno, Radziłów, Rajgród, Szczuczyn, Stawiski, Wąsosz, Wizna, będące miejscami masowych mordów dokonywanych przez Polaków na Żydach. Spalenie żywcem Żydów Jedwabnego 10 lipca 1941 roku było poprzedzone spaleniem żywcem Żydów Radziłowa 7 lipca 1941 roku. Masakra w Radziłowie z kolei była poprzedzona masakrą w Wąsoszu, również w stodole, 5 lipca 1941 


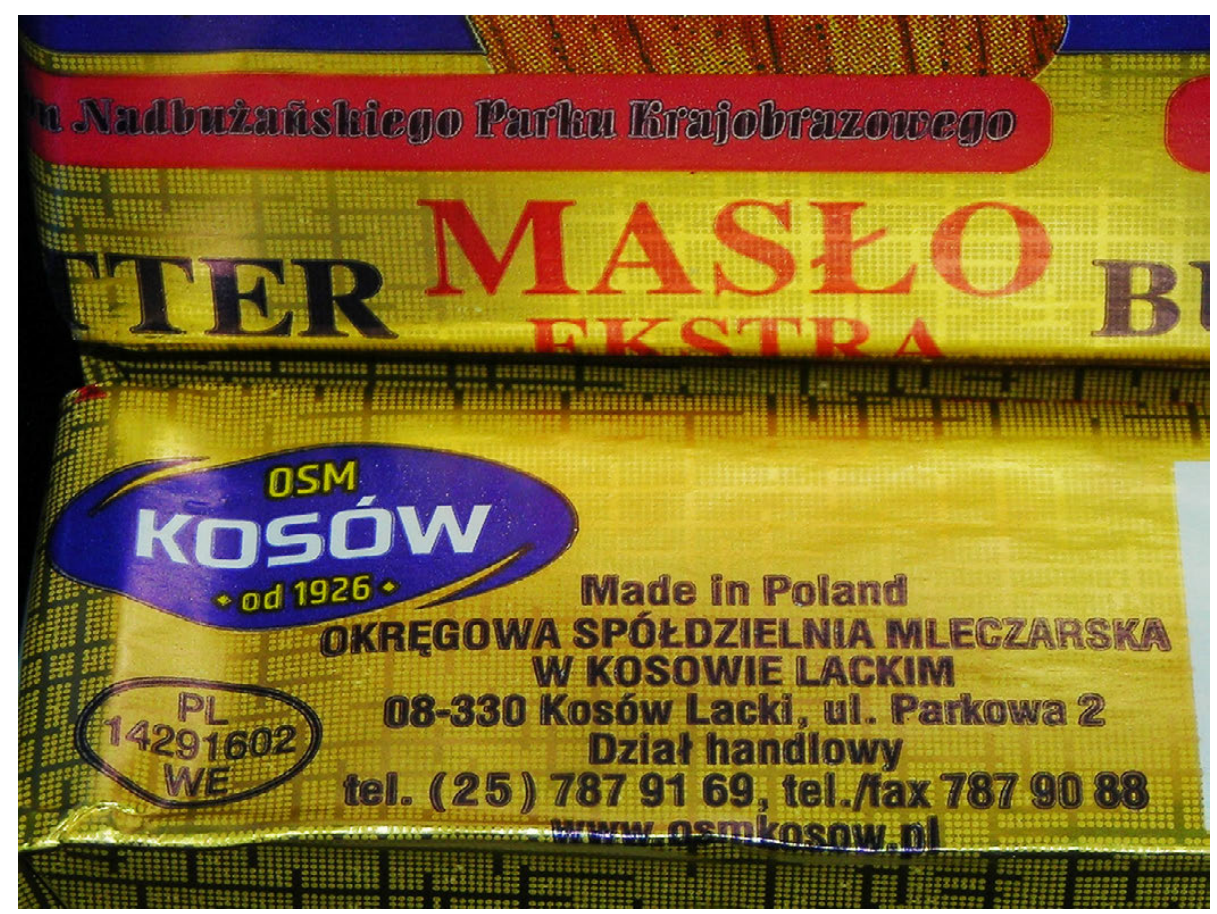

Masło ekstra z „regionu Nadbużańskiego Parku Krajobrazowego” z Okręgowej Spółdzielni Mleczarskiej w Kosowie Lackim (8 kilometrów od Treblinki II) w warszawskim sklepie spożywczym - 5 stycznia 2020 (fot. Elżbieta Janicka)

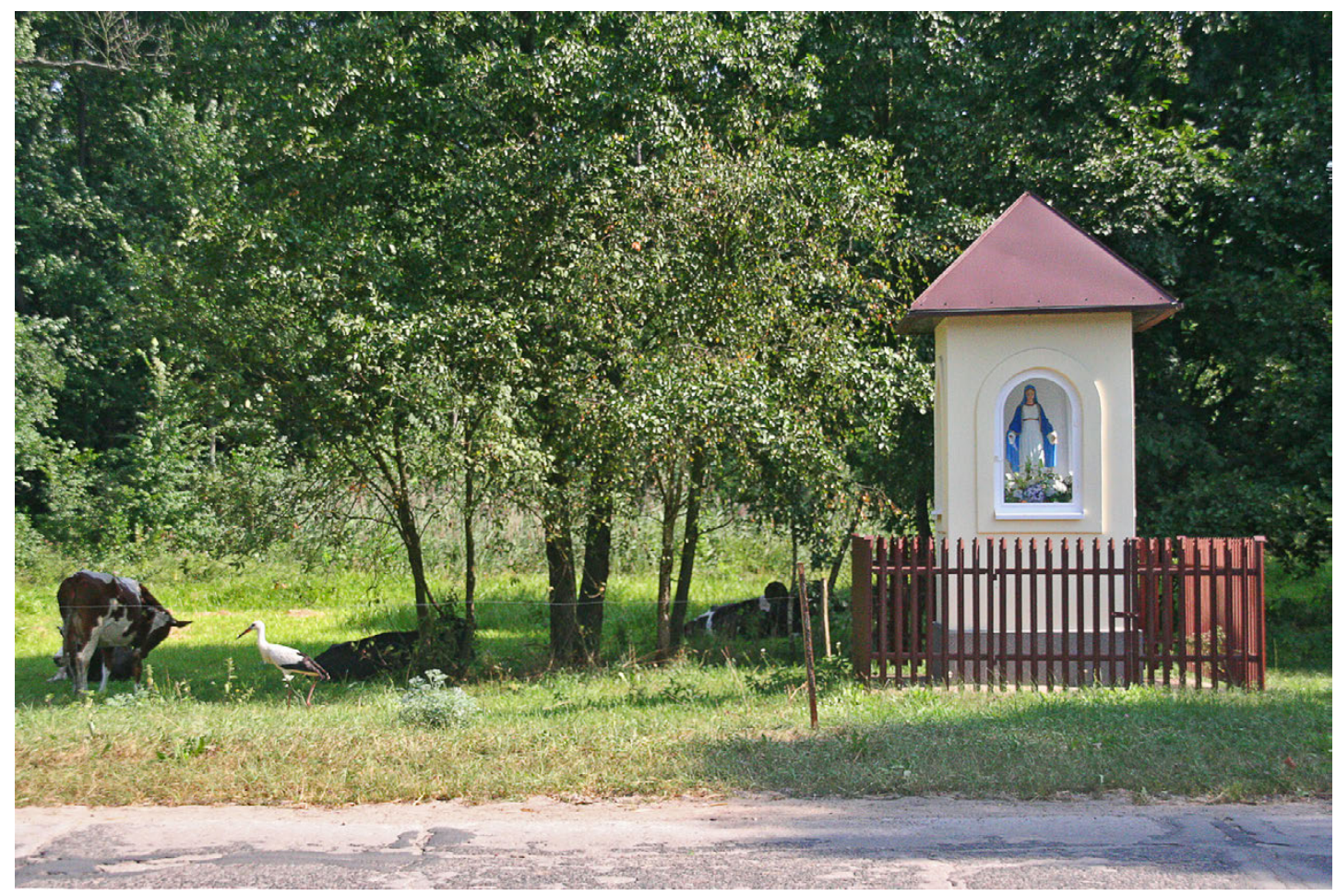

Wjazd do wsi Grądy i Poniatowo położonych między wsią Treblinka a obozem zagłady Treblinka II. Na pierwszym planie betonowa droga Małkinia-Kosów Lacki wybudowana przez miejscowych żydowskich robotników przymusowych przed niemiecką inwazją na ZSRR 22 czerwca 1941 roku - 19 sierpnia 2017 (fot. Elżbieta Janicka) 
Drogi. I nie inny niż ten, skąd wywodzili się gospodarze walczący z gospodarzami z Prostyni. Obie miejscowości leżą w promieniu ośmiu kilometrów od obozu śmierci. Prostyń kwitła przed wojną jako katolickie centrum pielgrzymkowe. Rolnicy z Kosowa Lackiego bili się po wojnie z rolnikami z Prostyni o prawo własności, a następnie utylizacji i handlu w odniesieniu do żydowskich prochów Treblinki (Canin, 2018b, ss. 235-236).

Wyroby mleczne z Kosowa Lackiego są smaczne. Innymi słowy, wyroby mleczne z Kosowa Lackiego są dobre. Sprzedawane jako żywność ekologiczna i reklamowane - bezpośrednio na opakowaniu - jako pochodzące z Nadbużańskiego Parku Krajobrazowego. Jeśli komuś nie odpowiada ich pochodzenie, to może sobie kupić masło z mleka krów pasących się na żydowskich szczątkach wokół Grajewa lub Zambrowa: odpowiednio masło ekstra łaciate i mlemix zambrowski. Ich reklamy głoszą: „zrobione z polskiego mleka”, „produkt polski”, „polskie z natury”. Wybór należy do ciebie. (Masło z Kosowa w Nadbużańskim Parku Krajobrazowym jest tańsze niż to z Grajewa w Biebrzańskim Parku Krajobrazowym, dokąd trafia mleko krów z Jedwabnego). W kategorii hortus judeorum Treblinka nie jest wyjątkiem, lecz elementem zbioru ilustrującym jego regułę. Patrzę na nią jak na pars pro toto. Jednakże - ponieważ jest ono najlepsze ze wszystkich, jakie kiedykolwiek jadłam - to na maśle z Kosowa Lackiego piekę i gotuję dla tej, która mnie wykarmiła własnym mlekiem.

\section{Łąki mojego dzieciństwa}

$$
\begin{array}{r}
\text { Drzewa mojego dzieciństwa przepłynęły ocean } \\
\text { i pozdrawiały mnie oschle z ekranu. } \\
\text { Polscy chłopi wdawali się w teologiczne spory } \\
\text { z jezuicką swadą, tylko Żydzi milczeli, } \\
\text { zmęczeni długim umieraniem. } \\
\text { Strumienie moich wakacji płynęły ostrożnie } \\
\text { przez nieznany sobie, obcy kontynent. } \\
\text { Wozy drabiniaste wiozły włosy zamiast siana } \\
\text { i skrzypiały ich osie pod puszystym ciężarem. } \\
\text { Jesteśmy niewinne, oświadczały sosny. } \\
\text { Adam Zagajewski (Zagajewski, 1988, s. 50) }
\end{array}
$$

Spostrzeżenia, które zapisałam w Hortus Judeorum, opadły mnie wszystkie jednocześnie po raz pierwszy w 2003 roku podczas podróży z Bełżca do Sobiboru PKS-em relacji Narol-Włodawa. Miałam wtedy okazję wysłuchiwać godzinami sowizdrzalskich opowieści o Zagładzie z polskiej perspektywy. Moi towarzysze podróży płci obojga nie mogli się od nich powstrzymać - ku powszechnej uciesze, wyjąwszy kierowcę autobusu, który nie zdradzał oznak uczestnictwa we wspólnej zabawie. I tak, Narola dotyczyła wojenna historia „Żydóweczki-istny-cymes z warkoczami i dzieciakiem”, zgwałconej i zabitej wraz z dzieckiem. Opowiadających było dwoje. Kobieta mówiła o ofierze „chytra Żydowica”, a podziw walczył w jej głosie o lepsze ze złością. Z Żółkiewki pochodziła opowieść o polowaniu na Żydów - publicznym i spektakularnym jak zwykle. O powo- 
jennym rabowaniu żydowskiego cmentarza w Izbicy opowiadał jeden ze sprawców, w owym czasie chłopiec, później - „za Gomułki” - dumny członek Kompanii Reprezentacyjnej Wojska Polskiego. Zapamiętał zwłaszcza zwłoki, a raczej damską torebkę osoby, o której wyrażał się „stara Żydówka”. Torebka była mała. Balowa tak jakby. Mała i pusta. „Pusta czy nie - skomentowała pasażerka w średnim wieku - wszystko na nic. Dalej nami rządzą”. „Taki Balcerowicz”20 - dodał starszy pasażer. A wszystko z towarzyszeniem rozległej panoramicznej ekspozycji i nieprzerwanej parady krajobrazu. Zrobionego z Żydów. Nafaszerowanego Żydami. Narzędzia zbrodni i wytworu zbrodni. Idyllicznego landszaftu. Imponującego. Napierającego. Zapierającego dech w piersiach. Ogrodu zagłady Polska.

Oglądając Shoah (Lanzmann, 1985) w pokoju hotelowym w Stanach Zjednoczonych, Adam Zagajewski zauważył: „Drzewa mojego dzieciństwa przepłynęły ocean / i pozdrawiały mnie oschle z ekranu" (Zagajewski, 1988, s. 50). Bo też i takie wrażenie wywiera Shoah na osobie wychowanej w Polsce. Bez potrzeby przemieszczania się do Ameryki. Bez potrzeby przemieszczania się w ogóle. Macbeth i Lady Macbeth nie potrzebowali się przemieszczać. Las Birnamski przemieścił się za nich wystarczająco skutecznie. Po tym rozpoznali to, co długo starali się wyprzeć, ale o czym nigdy nie zapomnieli tak naprawdę, a mianowicie - kim są z powodu tego, co zrobili. W wierszu Zagajewskiego jest patos i terror tego samorozpoznania, które w polskim i wschodnioeuropejskim kontekście przechodzi przez rozpoznanie w Arkadii locus horridus.

Anna Markiel, której ojciec ujawnił masakrę dokonaną przez Polaków na Żydach w jego rodzinnej Gniewczynie w 1942 roku:

Ja się tam czułam bezpieczna. [...] Poczułam się jak ktoś, kto miał przepiękny dzban i nagle widzi go w skorupach. Jeśli nawet je pozlepia, to już nie będzie to samo naczynie. Wspomnienia z dzieciństwa w Gniewczynie odgrodziłam, w tej chwili są jak bajka, jakby mnie tam naprawdę nigdy nie było. To miejsce ukochane, związane z moimi rodzicami, w którym wszystko wydawało się piękne, straciło niewinność. Powietrze pachnie mi inaczej, czuję inny wiatr w drzewach, ścieżki są dla mnie obce. Nawet stosunek do ludzi mam inny (Grochowska, 2012, s. 34).

Ewa Andrzejewska, zrozumiawszy - nie dowiadując się nawet dokładnie - co Polacy uczynili Żydom w Nowym Sączu: „Łąki przestały być dla mnie bezpieczne i beztroskie” (Sulej, 2011, s. 11). Rūta Vanagaité, odkrywszy litewskie sprawstwo zagłady litewskich Żydów: „Nie mogę już chodzić na cmentarz moich rodziców, bo ciągle przypominają mi się tamte miejsca. Nie mogę kłaść kwiatów na ich grobie, bo wiem, że w całym kraju leżą ludzie pochowani jak szczury” (Kącki, 2016, s. 21).

Niebezpieczeństwo nie przychodzi z krajobrazu. Niebezpieczeństwo jest samym krajobrazem. Krajobraz jest niebezpieczeństwem. Krajobraz dzieciństwa. Dzieciństwa Zaga-

20 Leszek Balcerowicz - ekonomista, przed 1989 rokiem członek Polskiej Zjednoczonej Partii Robotniczej, po 1989 roku premier i minister finansów, autor neoliberalnej transformacji ekonomiczno-społecznej osłanianej puklerzem mowy nienawiści dostarczanej przez polską inteligencję i Kościół, a wymierzonej w miliony ofiar neoliberalizmu flamboyant à la polonaise (zob. Ost, 2007; Kowalik, 2009; Gomułka \& Kowalik, 2011; Gomułka, 2019). Nie mając nic wspólnego z czymkolwiek, co byłoby jakkolwiek żydowskie, w potocznej wyobraźni Balcerowicz stanowi uosobienie fantazmatycznej figury Żyda. 
jewskiego. Mojego dzieciństwa. „Naszego” dzieciństwa w sensie, w jakim Dante mówił o „naszym życiu”, nostra vita. Krajobraz, którym najzupełniej dosłownie zostaliśmy wykarmieni. Z którego składamy się do tego stopnia, że nie jesteśmy w stanie odróżnić się od niego i zeń wyabstrahować. Niebezpieczeństwo to zatem „my” sami. Gdyż z czego zrobione jest - i przez kogo - to, z czego ja jestem zrobiona? To jest właśnie to, owo Das, Realne, kwestia, której dotyczy kwestia.

Najbliższe i najbardziej swojskie samounicestwia się tutaj wraz z poczuciem bezpieczeństwa i poczuciem tożsamości podmiotu samego ze sobą - tożsamości, która była dotąd nieproblematyczna. Oto das Unheimliche: radykalnie tożsame doświadczone jako radykalnie różne, radykalnie tożsame rozpoznane jako radykalnie różne. I radykalna tożsamość obydwu. Radykalnie bezpieczne rozpoznane w radykalnie zagrażającym i jako radykalnie zagrażające. Wykorzenienie, jednym słowem. Radykalna eradykacja. Egzystencjalna i esencjalna. A także wyzwolenie. Nie w sensie uwolnienia się podmiotu od samego siebie - to nie jest możliwe - lecz w sensie przejęcia nad sobą kontroli. Objęcia siebie w posiadanie. Nigdy więcej jałowego strachu. Nigdy więcej przeciwskutecznych ucieczek. Ulga niewymowna. Energia mentalna i emocjonalna uwolniona w kierunku Realnego, raz jeszcze w Lacanowskim sensie tego słowa. Łąki „naszego” dzieciństwa są niemożliwe do odzyskania... w żaden inny sposób.

O tym są dla mnie dzisiaj wersy Canto Primo:

Nel mezzo del cammin di nostra vita mi ritrovai per una selva oscura, ché la diritta via era smarrita.

(Dante, 1991, s. 26, w. 1-3)

Mi ritrovai - uparcie tłumaczone jako: zagubiłem się - dosłownie znaczy: znalazłem się. Jeśli nie: odnalazłem się na powrót / znowu. A zatem, odnalazłam się. Ponieważ prosta droga została zgubiona. Czy to nie współbrzmi z zaleceniem Nachmana z Bracławia, żeby nie pytać o drogę tego, kto ją zna, gdyż nie będzie można jej wówczas zgubić? Ni Dieu, ni maître. (Chyba że Gott mit uns). W lesie. Znajdujemy się. Ze sobą. Sam na sam.

Ahi quanto a dir qual era è cosa dura esta selva selvaggia e aspra e forte che nel pensier rinova la paura!

Tant' è amara che poco è piu morte; (Dante, 1991, s. 26, w. 4-7)

Tak. Nostra vita - o ile w ogóle - jest niemożliwa do odzyskania w żaden inny sposób ${ }^{21}$.

21 Pisząc o rzekach łez łączących swe dorzecza w piekle, kongenialna tłumaczka Dantego, Jacqueline Risset, dodawała: „Myśli się o straszliwej mapie Europy, którą nadal można oglądać w Auschwitz, gdzie sekretna sieć zajęła miejsce znanej sieci połączeń kolejowych: figurują na niej wszystkie stolice ze swoimi nazwami, lecz nie są one skomunikowane wzajemnie ze sobą - jedna i ta sama linia łączy je wszystkie, jedną po drugiej, z centralnym punktem sieci oznaczonym nazwą AUSCHWITZ" (Risset, 1991, s. 9). Długi czas uważałam to podejście za nieuprawnione i nie na miejscu. Dzisiaj myślę, że nie jest możliwe inne podejście do społecznego i kulturowego dziedzictwa. Nie dlatego, że Zagłada była ich nieuniknioną konsekwencją, lecz dlatego, że można było jej uniknąć. Prawdopodobnie nie zaczęłabym myśleć na ten temat, gdyby nie spektakularna postać mojej nauczycielki z Université Paris VII Denis Diderot, Marie Depussé (z psem). Marie Depussé wmuszała 


\section{Od Hortus ludaeorum do Herbarium Polonorum}

[B]yłem bombą, ale nieszkodliwą - brakowało detonatora. Treblinka mnie zapaliła, wybuchłem tego popołudnia z niepodejrzewaną, niszczycielską siłą. Jak to inaczej powiedzieć? Treblinka stała się prawdziwa, w jednym oślepiającym błysku nastąpiło przejście od mitu do rzeczywistości, spotkanie nazwy z miejscem zmiotło całą moją wiedzę, zmuszając mnie do rozpoczęcia wszystkiego od zera, do radyklanej zmiany spojrzenia na to, czym się do tej pory zajmowałem, do wywrócenia wszystkiego, co wydawało mi się niezbicie pewne, a przede wszystkim do wyznaczenia Polsce będącej ośrodkiem geograficznym eksterminacji należnego jej miejsca, najważniejszego miejsca. Treblinka stała się tak prawdziwa, że nie wolno było zwlekać ani chwili, poczułem, że trzeba działać już, natychmiast [czy raczej: zawładnęła mną krańcowa nagłość, pod której presją będę żył nieprzerwanie od tamtej pory - E. J.] [...].

Claude Lanzmann (Lanzmann, 2010, ss. 452)22

Oprócz myślowej progresji istnieje podstawowa, techniczna, logistyczna - by tak rzec - więź między Miejscem nieparzystym a Zielnikiem. Pierwsze fotografie roślin, jakie wykonałam, pochodzą z 10 lipca 2004 roku. Nie miały one wówczas nic wspólnego z żadną systematyczną pracą, a co dopiero jakąkolwiek konceptualizacją. Pojechałam do Treblinki, by zrobić zdjęcia i nagrania do Miejsca nieparzystego. Przez czysty przypadek - jako że czystość unosi się tu w powietrzu - było to w rocznicę spalenia żywcem Żydów z miasteczka Jedwabne przez Polaków z miasteczka Jedwabne w 1941 roku. Do Treblinki pojechałam z powodu powietrza i ziemi, lekceważąc wszystko inne jako wtórne, jako podrobioną dekorację teatralną, integralną część zestawu kommemoratywnego (Treblinka I, Czarna Droga, Treblinka II), który podejrzewałam w całości o wszystkie możliwe sprzeniewierzenia. Jedyne, czemu wierzyłam, to powietrze i ziemia. I beton.

Gdy zobaczyłam, co się dzieje tam - na betonowych płytach - fotografowanie okazało się silniejsze ode mnie. To było nagłe. Nagle dotarło do mnie, że jestem otoczona roślinami. Niemymi i dyskretnymi z pozoru, niemożliwymi do niezauważenia w istocie. Rosły wszędzie wokół. Nie jako masywy kwietne czy wśród zespołów zieleni, lecz pojedynczo. Wprost na betonie. Doskonale przeciętne i pospolite. Łatwo rozpoznawalne. Całkowicie odsłonięte. Samooczywiste. Przezroczyste. Do szpiku kości. Nie przypominały znaków zapytania. Były wykrzyknikami. Z kości i krwi.

Miałam do czynienia z fraktalem, próbką Realnego. Z biegiem czasu jeżdżenie na miejsce, przebywanie w nim, badanie jego konstytutywnych elementów poprzez fotografowanie stało się dla mnie mentalnym i emocjonalnym przymusem. Uzależnieniem

w nas studia nad całością dzieła Dantego w wersji dwujęzycznej i w tym celu organizowała nam warsztaty z Jacqueline Risset.

22 Całe zdanie w tłumaczeniu Maryny Ochab brzmi: „Treblinka stała się tak prawdziwa, że nie wolno było zwlekać ani chwili, poczułem, że trzeba działać już, natychmiast; że trzeba kręcić, rozpocząć zdjęcia jak najwcześniej, tego dnia dostałem na to pozwolenie" (Lanzmann, 2010, ss. 452). W nawiasie kwadratowym umieściłam tłumaczenie własne fragmentu cytowanego zdania. A oto całe zdanie w oryginale: „Treblinka devint si vrai qu'il ne souffrit plus d'attendre, une urgence extrême, sous laquelle je ne cesserais désormais de vivre, s'empara de moi, il fallait tourner, tourner au plus tôt, j'en reçus, ce jour-là, le mandat” (Lanzmann, 2009, s. 493). 


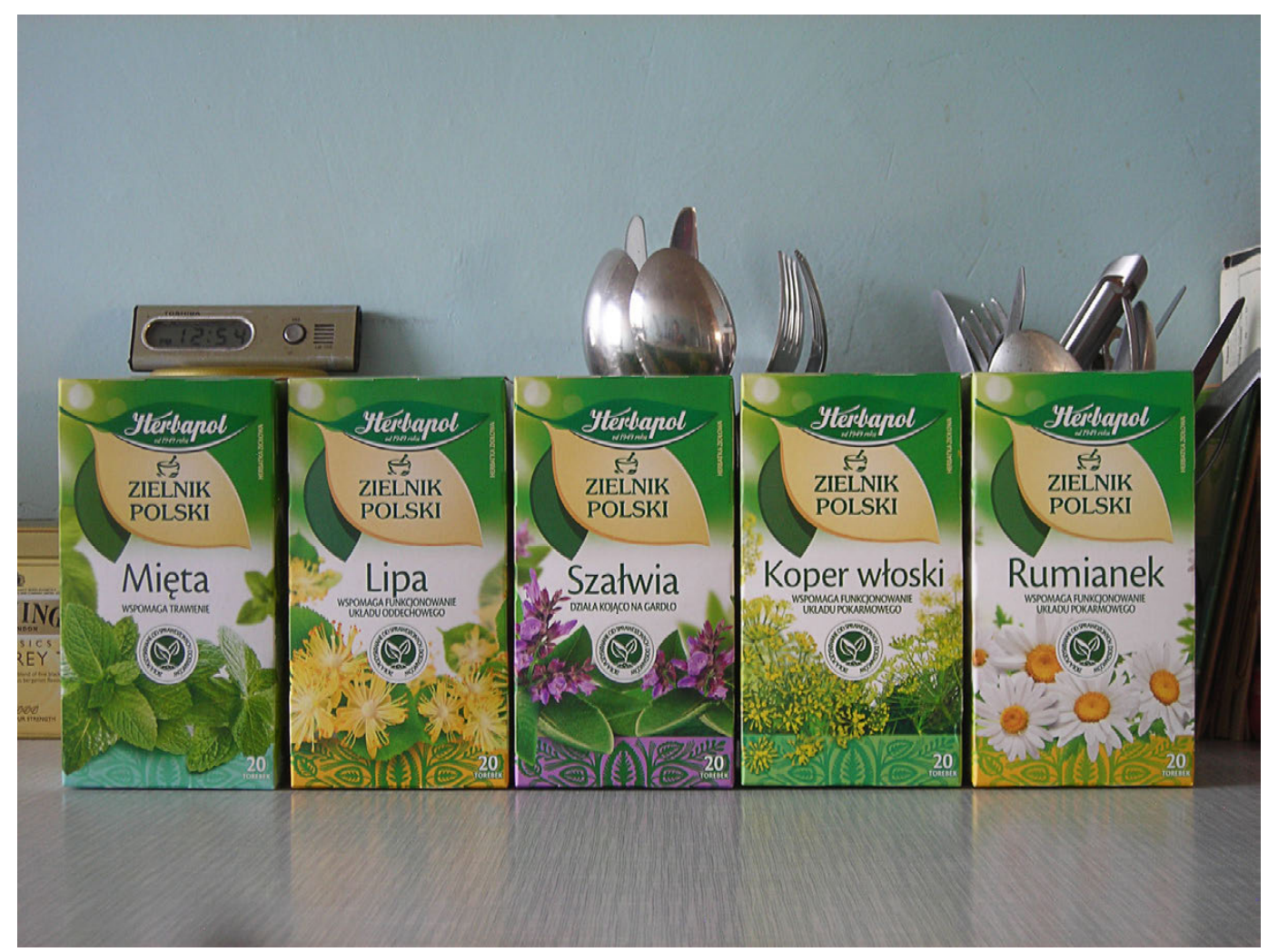

Linia herbat ziołowych Zielnik Polski (ang. Polish Herbarium, łac. Herbarium Polonorum) w kuchni autorki Warszawa, 5 stycznia 2020 (fot. Elżbieta Janicka)

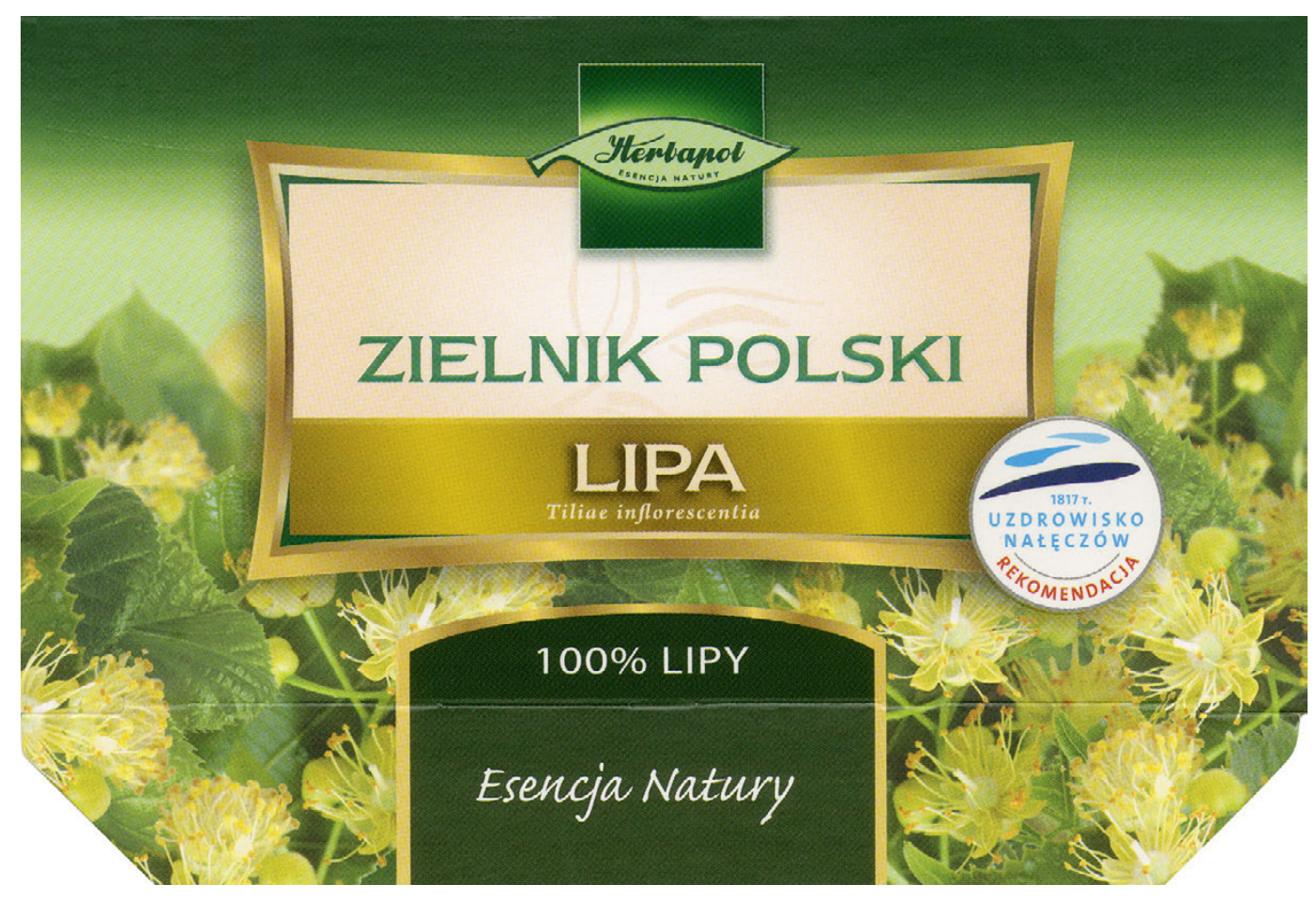

„Zielnik Polski. Lipa. Tiliae inflorescentia. 100\% lipy. Esencja natury” z rekomendacją uzdrowiska Nałęczów założonego w 1817 roku - opakowanie z 2013 roku w zbiorach autorki (fot. Elżbieta Janicka) 


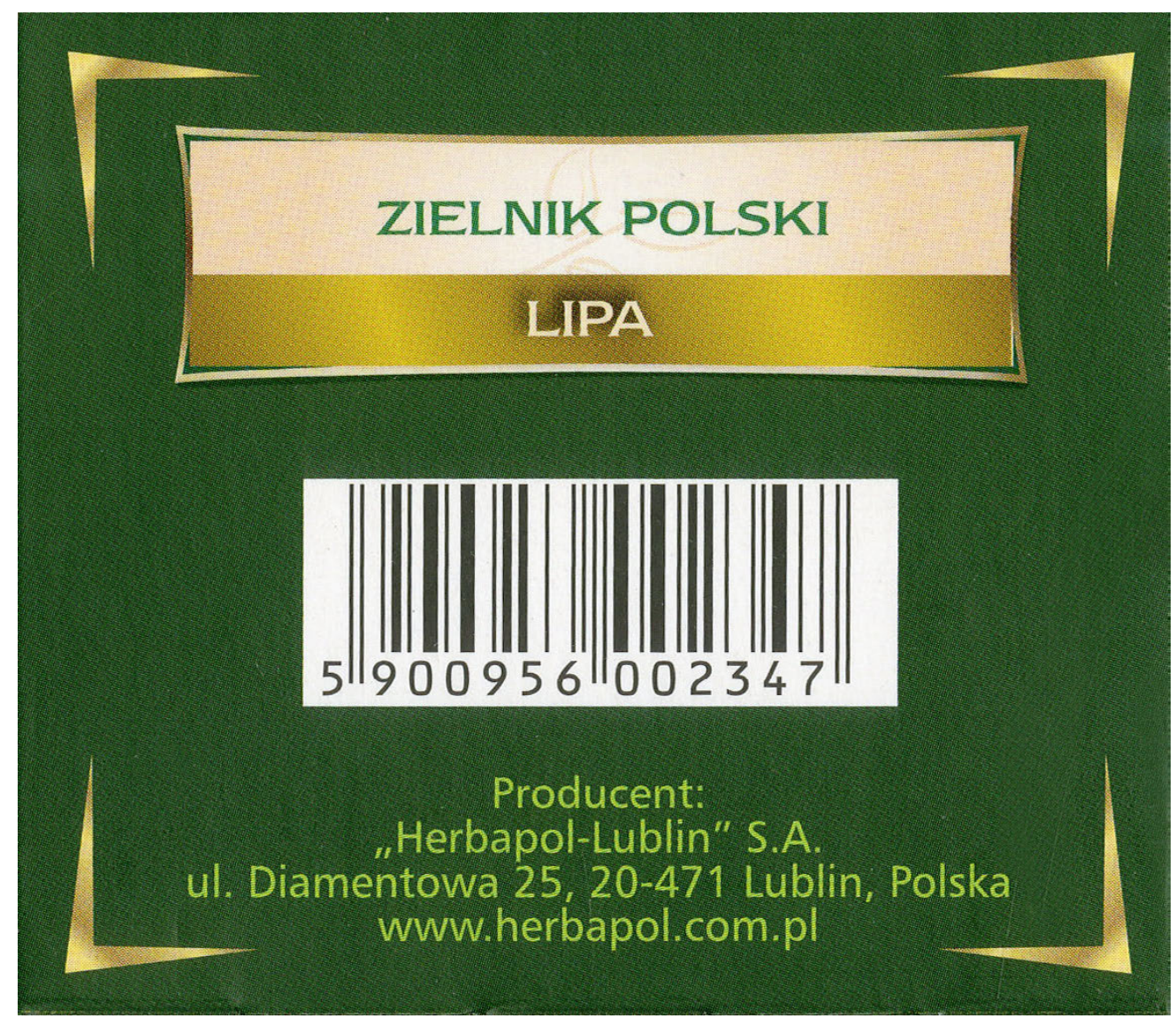

„Zielnik Polski. Lipa. Producent: «Herbapol-Lublin» S.A., ul. Diamentowa 25, 20-471 Lublin, Polska” opakowanie z 2013 roku w zbiorach autorki (fot. Elżbieta Janicka)

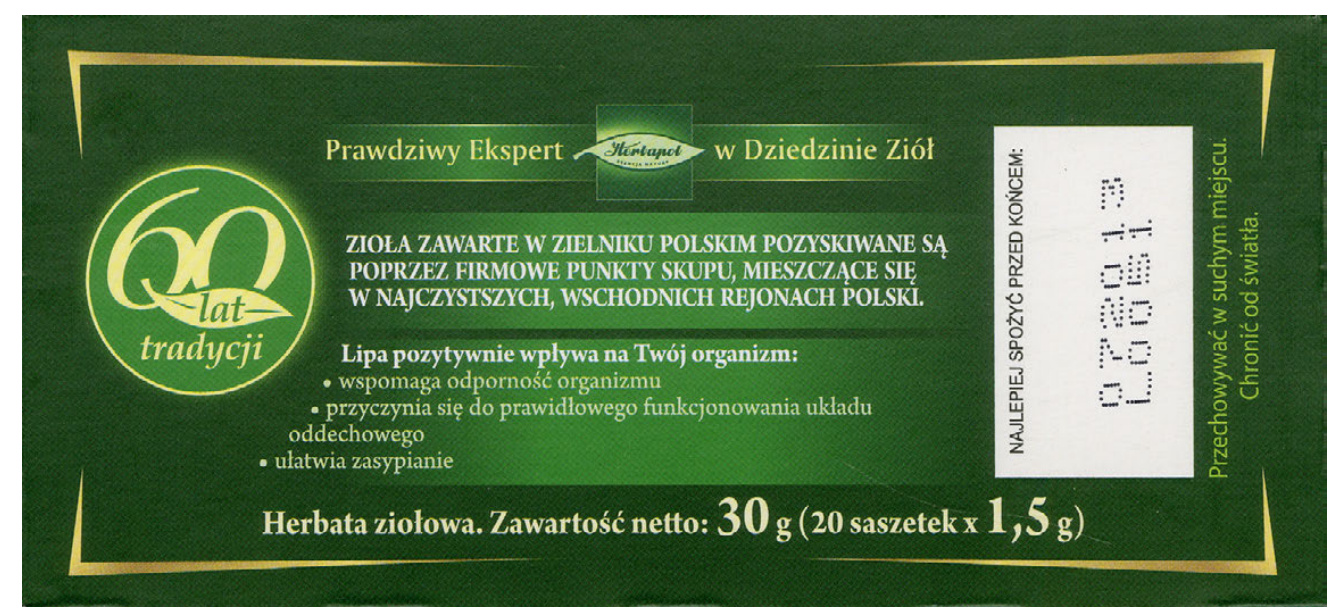

„60 lat tradycji. Zioła zawarte w Zielniku Polskim pozyskiwane są poprzez firmowe punkty skupu, mieszczące się w najczystszych, wschodnich rejonach Polski" - hasło reklamowe z opakowania Zielnika Polskiego z 2013 roku w zbiorach autorki (fot. Elżbieta Janicka)

\section{„Lipa pozytywnie wpływa na twój organizm:}

- wspomaga odporność organizmu

- przyczynia się do prawidłowego funkcjonowania układu oddechowego

- ułatwia zasypianie" 
poznawczym. Odzyskiwanie i wiwisekcja letnich ekstaz własnego - a przez to samo „naszego” - dzieciństwa nie jest zupełnie prostą sprawą. Przez długi czas operowałam poza językiem i nie będąc zdolna do ujęcia w słowa tego, co robiłam. Tylko wizualnie wiedziałam z całą pewnością, o co mi chodzi, i starałam się to wyartykułować w obrazie najlepiej, jak umiałam. Zdolności werbalizacji dobijałam się z mozołem, stopniowo.

Robiąc zakupy w spożywczym pod blokiem, zauważyłam kątem oka rząd starannych fotograficznych portretów roślin „naszego” dzieciństwa. Była to sklepowa wystawa serii herbat ziołowych: Zielnik Polski. Po łacinie: Herbarium Polonorum. I ta sama idea zielnika, którą tłumaczono - cały czas w obrębie łaciny - na pojęcia takie, jak hortus siccus (suchy ogród), hortus hiemalis (ogród zimowy), hortus mortus (martwy ogród). Na poziomie pojęciowym znalazłam się zatem pomiędzy: hortus iudaeorum a herbarium polonorum. $\mathrm{Na}$ poziomie dosłownym jednakże oba pojęcia odsyłały do jednego i tego samego, żywego i martwego - żywego martwego - uniwersum. Desygnaty obu znaków składały się były zrobione - z jednej i tej samej rzeczywistości materialnej. Były fraktalami krajobrazu Polski.

Wtedy to wydarzyt się dialog. Na Wielkanoc 2012 roku. 6 kwietnia. Na miejscu. Między kimś, dla kogo to był pierwszy raz, a kimś, kto zwykł jeździć tam i przestawać godzinami. Między kobietą a mężczyzną. Między antropolożką kultury (M. Z. - inicjały) a bibliotekoznawcą. Między profesorką a doktorem. Dla tej pierwszej był to szok jej życia.

Profesor: Wierzby tutaj?!

Doktor: Nic bardziej pospolitego niż wierzby na Mazowszu²3. Wierzba to emblemat regionu. Profesor: Hm, spodziewałam się palm.

Doktor: Palm?!

Profesor: Palm.

Doktor: I cedrów Libanu?24

23 Mazowsze to region usytuowany w sercu Polski z Warszawą jako stolicą. Jest on potocznie identyfikowany z wierzbą, folklorem łowickim i muzyką Fryderyka Chopina urodzonego w Żelazowej Woli i czerpiącego z lokalnej tradycji ludowej. Po 1945 roku ów zestaw stał się emblematem tak zwanej prawdziwej polskości, przejmując sztafetę od imaginarium mającego za ośrodek tak zwane Kresy. Zmiana ta była podyktowana geopolityczną rekonfiguracją Polski po tym, jak przestała ona być kolonialną ciemiężycielką Litwy, Białorusi i Ukrainy, wcielonych z kolei do ZSRR (tym razem wszakże jako odrębne republiki narodowe). Składowe mazowieckiej triady emblematycznej są nierozdzielne i symbolicznie równoważne. W dominującym polskim imaginarium nie ma znaczącej różnicy afektywnej między wierzbami, muzyką Chopina a łowicką wycinanką (skrzętnie skrywanego żydowskiego pochodzenia). Wystarczy wspomnieć ikonografię polskich symbolicznych towarów eksportowych: Państwowego Zespołu Pieśni i Tańca „Mazowsze” czy Międzynarodowego Konkursu Pianistycznego im. Fryderyka Chopina, słynącego ze swoich zwycięzców - jak Martha Argerich czy Krystian Zimmerman, oraz przegranych - jak Ivo Pogorelić. Najsłynniejszy pomnik Chopina - w warszawskich Łazienkach, dłuta Wacława Szymanowskiego (zaprojektowany w 1904 roku, odsłonięty w 1926, zniszczony przez Niemców w 1940, odbudowany w roku 1958) - przedstawia kompozytora siedzącego pod wierzbą. Świadom tożsamościowego ładunku wierzby, Mariusz Łukawski, profesor łódzkiej Akademii Sztuk Pięknych im. Władysława Strzemińskiego, zwykł straszyć swoich studentów: „Jeśli nie będziecie pracować dostatecznie ciężko, skończycie, lepiąc z gipsu i papier mâché wierzby płaczące i kości przodków”. Miał na myśli ulepszoną - gdyż „rozszerzoną” o kości przodków - wersję pamiątek z Polski.

24 Doktor odnosi się do wersu „Sprawiedliwy jak palma zakwitnie, jak cedr Libanu wystrzeli” (Psalm 92:13, cyt. za: Psalmy, 1883, s. 271). Jakkolwiek tłumaczeniem mojego dzieciństwa było „Sprawiedliwy zakwitnie jak palma, rozrośnie się jak cedr na Libanie” (Psalm 92:13, cyt. za: Księga Psalmów, 2003). 
Profesor: Tak - ich poczucie humoru wyraźnie nie było jednakowe. - Tak. Wierzby są tu nieendemiczne.

Nie będąc w stanie objąć rzeczy rozumem, powróciła do sprawy, spoglądając na miejsce ostatni raz przed odejściem:

Profesor: To muszą być tamte wierzby z psalmu²5.

Ona miała na szyi krzyż z Ukrzyżowanym. On miał na głowie kipę. On też przywiózł mi tę wymianę zdań z byłego obozu we wnętrzu byłego obozu (Totenlager, strefa śmierci) i ofiarował mi ją w charakterze prezentu ${ }^{26}$.

Oczywiście, że byłam oswojona z tego rodzaju imaginarium. Kwintesencją dominacji i podporządkowania. Zbiorem emblematów przemocy i wykluczenia. Kodem komunikacji pomiędzy „polskimi gospodarzami” a „żydowskimi gośćmi”. Językiem sublokatorstwa i samym sublokatorstwem jako kategorią kultury polskiej. Hanna Mortkowicz-Olczakowa, poetka, pisała o Franciszce Arnsztajnowej, poetce:

Pobudką do czynu, do pracy na polskim ugorze chciała rozciąć wiecznie krwawiący węzeł polsko-żydowskich konfliktów. Stwarzała wzniosłe metafory o cedrach Libanu, które przesadzone pomiędzy świerki północy trwają skrzepione ich mocą i sokami. W imię tułaczy, ,przybłędów”, wyznawała swą miłość do polskiej ojczyzny-matki, mimo to, że chwilami stawała się ona macochą i odpychała dzieci, „obce krwią i ciałem” (Mortkowicz-Olczakowa, 2006, s. 23).

Arnsztajnowa zginęła w warszawskim getcie. Ojciec Mortkowicz-Olczakowej, Jakub Mortkowicz, wydawca kanonu międzywojennej literatury polskiej, dobroczyńca pisarzy, odebrał sobie życie przed wojną. Jego ostatnie słowa przed śmiercią brzmiały: „Nie byŁem kupcem i nie umieram jak kupiec" (Olczak-Ronikier, 2002, s. 203). Zaiste, miała świadomość Mortkowicz-Olczakowa, o czym mówi ${ }^{27}$.

Wiedziałam o tym, podobnie jak wiedziałam o sposobach naturalizowania kulturowych konstruktów takich jak naród:

[J]asne jest, że dziedziczne mity i wspomnienia na temat krajobrazu posiadają dwa rysy charakterystyczne: zdumiewającą trwałość utrzymującą się przez wieki oraz zdolność kształtowania instytucji, w których nadal żyjemy. Tożsamość narodowa, by wziąć przykład najbardziej oczywisty, straciłaby wiele ze swego morderczego powabu bez mistyki danej tradycji krajobrazowej: jej topografii zmapowanej, opracowanej i nobilitowanej jako ojczyzna. [...] Pejzaże

25 Profesorka nawiązuje do Psalmu 137 Nad rzekami Babilonu. W oryginalnej wersji hebrajskiej mowa o topoli. Wszelako najbardziej znane i najznakomitsze literacko tłumaczenia na polski (Psałterz floriański, Psatterz Dawidów przekładania Jana Kochanowskiego czy wersja Jakuba Wujka), a także przekład Cylkowa, mówią o wierzbie i to wierzba przeszła do lokalnej żydowskiej tradycji poetyckiej jidysz i polszczyzny, jak to ma miejsce w przypadku - odpowiednio - utworów Hadasy Rubin i Bożeny Keff.

26 Por. list Henryka Hollendra do Elżbiety Janickiej z 9 kwietnia 2012 roku.

27 Wnuczka Jakuba Mortkowicza o swojej babce Janinie Horwitz-Mortkowicz i matce Hannie Mortkowicz-Olczakowej,żonie i córce Jakuba Mortkowicza: „Instynkt samozachowawczy mówit, by nie przystawać, nie rozpamiętywać, iść naprzód, nie oglądając się za siebie. [...] Przez całe życie podkreślały swoją polskość i nie chciały czy też nie umiały nazwać problemów życiowych i psychologicznych wynikających z żydowskiego dziedzictwa. [...] Podczas okupacji strach przed śmiercią mniej im chyba dolegał niż doznane poniżenia” (Olczak-Ronikier, 2002, s. 337). 


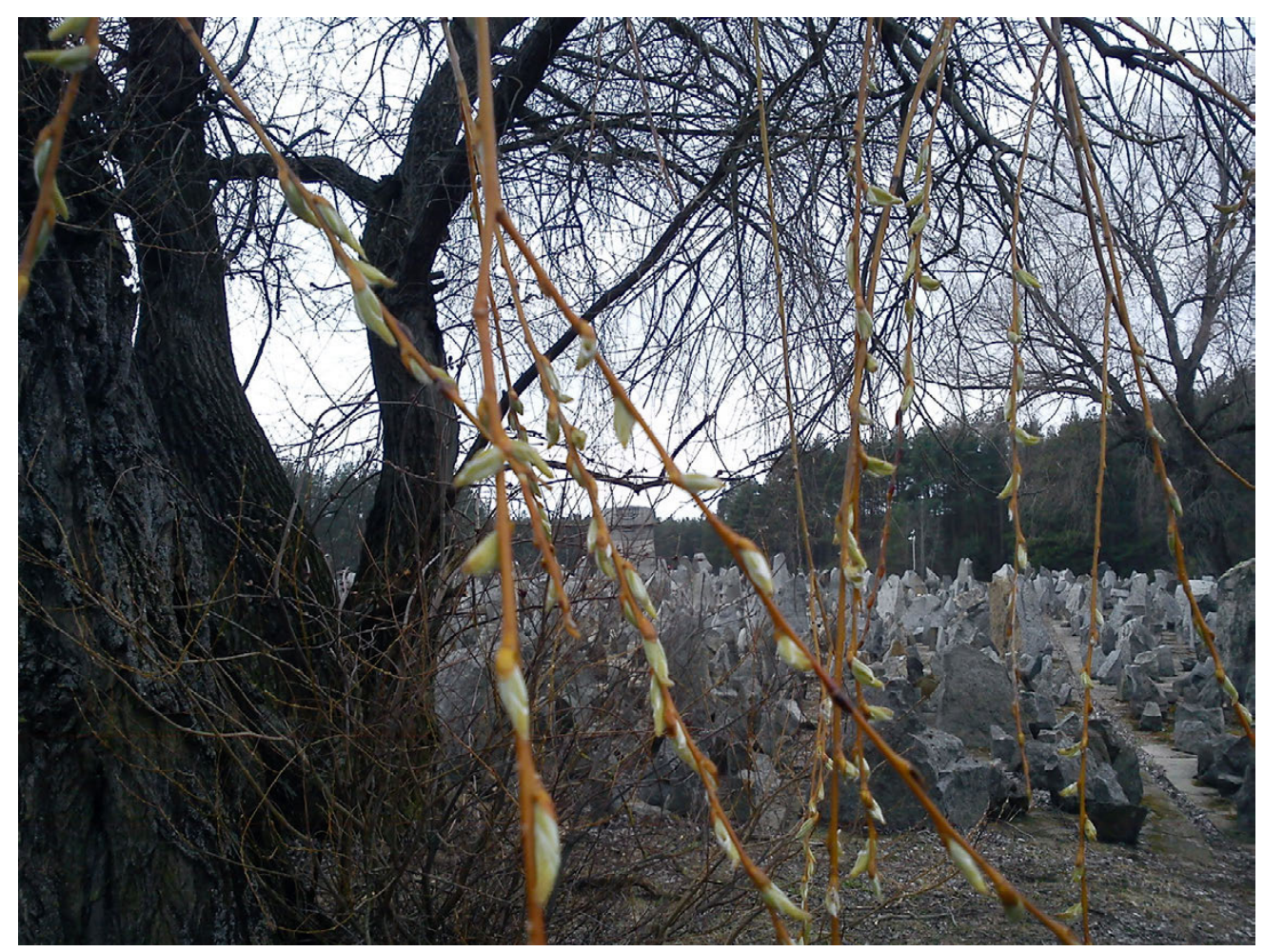

Wierzby Treblinki II. Widok w kierunku zachodnim - 6 kwietnia 2012 (fot. Henryk Hollender) (๔ by Henryk Hollender, dzięki uprzejmości Autora zdjęcia)

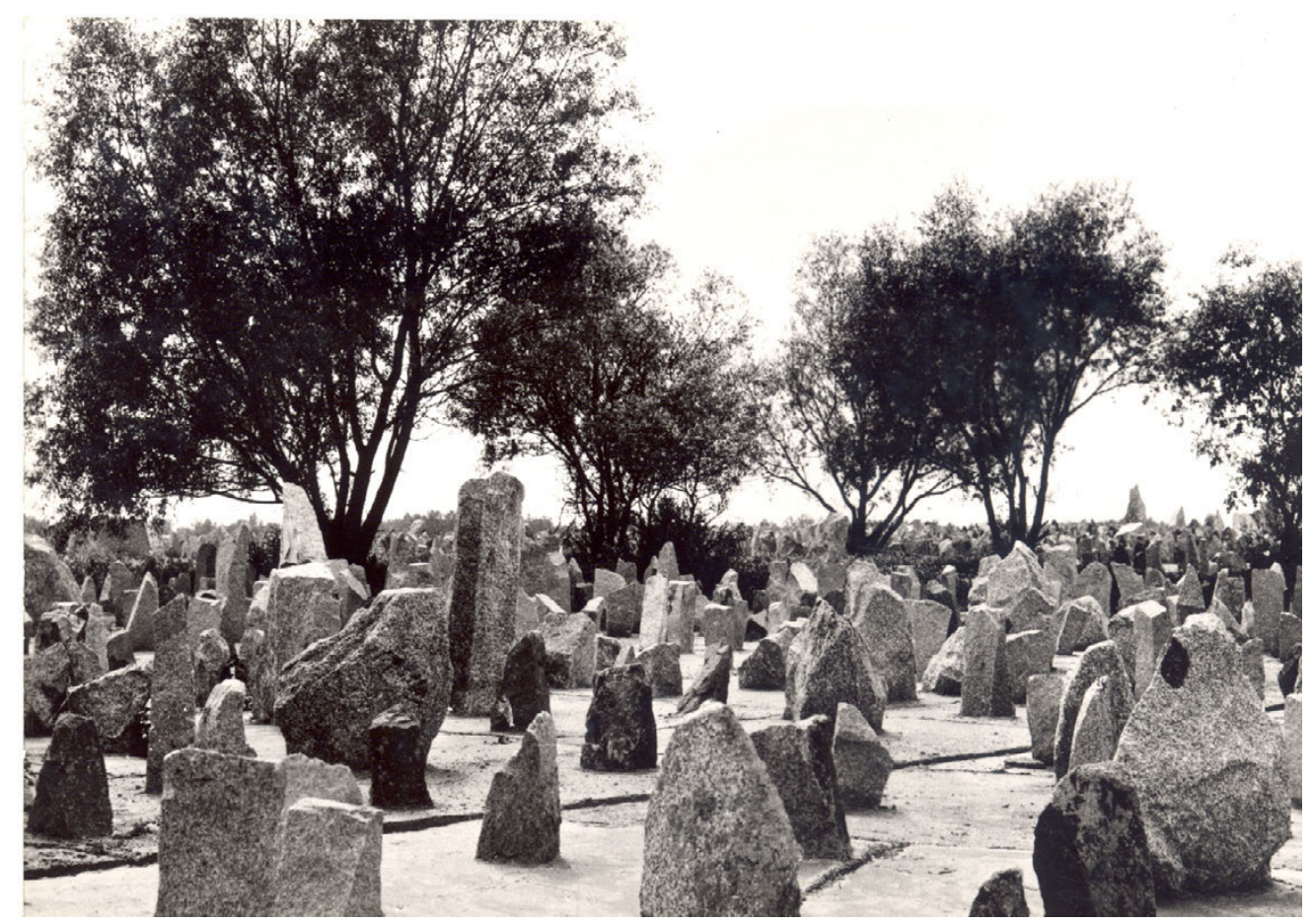

Wierzby Treblinki II w obiektywie Eustachego Kossakowskiego. Widok w kierunku wschodnim (pocztówka z lat sześćdziesiątych XX wieku, ze zbiorów Żydowskiego Instytutu Historycznego im. Emanuela Ringelbluma w Warszawie)

Na rewersie znajduje się informacja w językach polskim, angielskim, francuskim, niemieckim i rosyjskim: „Obóz zagłady 800 tysięcy ludzi z krajów Okupowanej Europy”. Biuro Wydawnicze „Ruch” na zlecenie Rady Ochrony Pomników Walki i Męczeństwa 


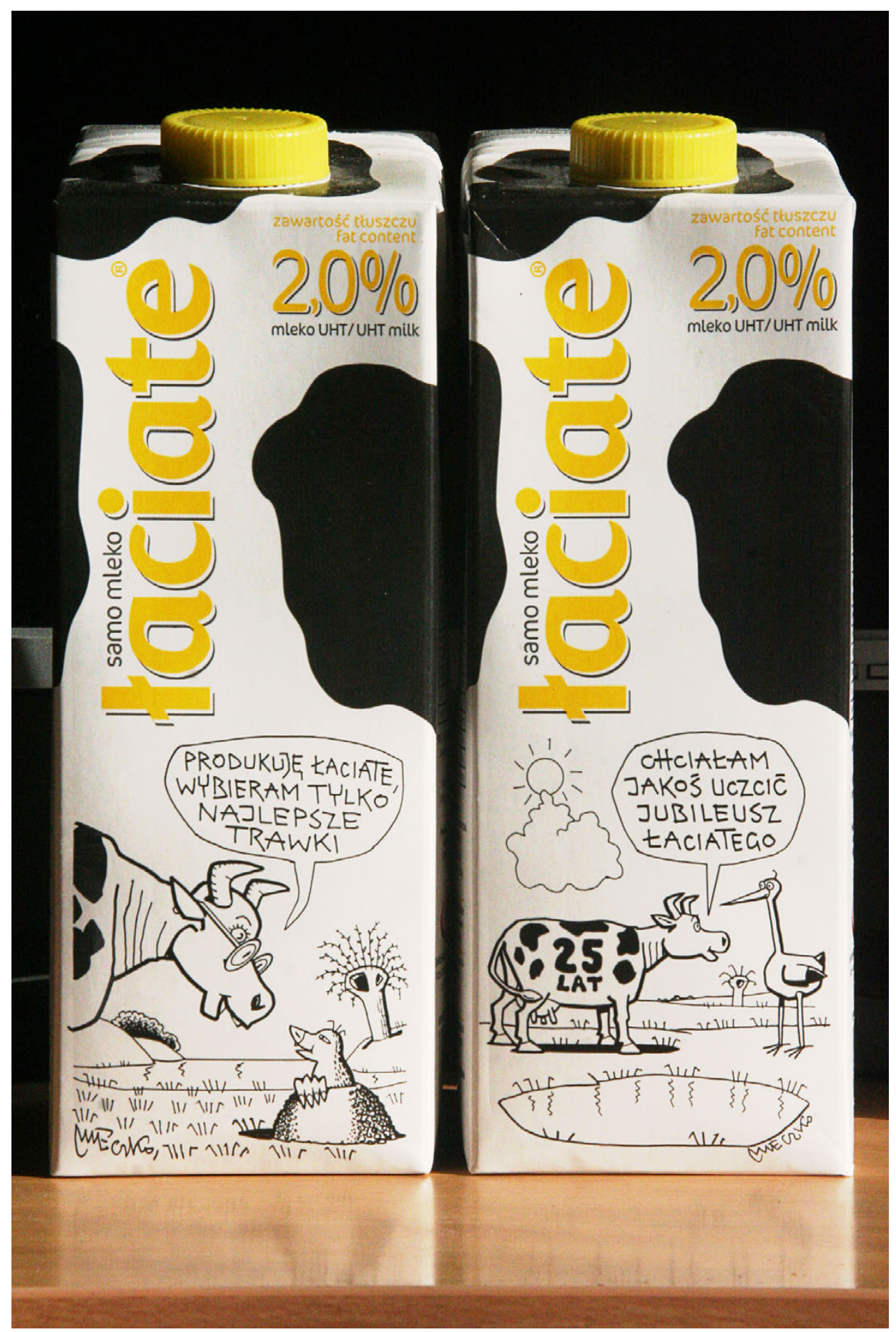

„Mleko łaciate” reklamowane jako „polskie z natury”. Kartony z jubileuszowymi rysunkami Andrzeja Mleczki z okazji dwudziestopięciolecia Spółdzielni Mleczarskiej MLEKPOL w Grajewie. Marka mleka - „łaciate” - nawiązuje do czarno-białych łat krasuli, czyli krowy uważanej za archetypalnie polską (por. hasło krasula, https://en.m.wiktionary, dostęp 31 sierpnia 2020). W swoich rysunkach Mleczko przywołuje ikony polskiego imaginarium, które nie może obejść się bez wierzby. Obecność archetypalnie polskiej wierzby w archetypalnie polskim krajobrazie jest oczywista i przezroczysta. Rysunkowa krasula nie ma potrzeby odnieść się do niej w wypowiedziach adresowanych do bociana i kreta (fot. Elżbieta Janicka) 


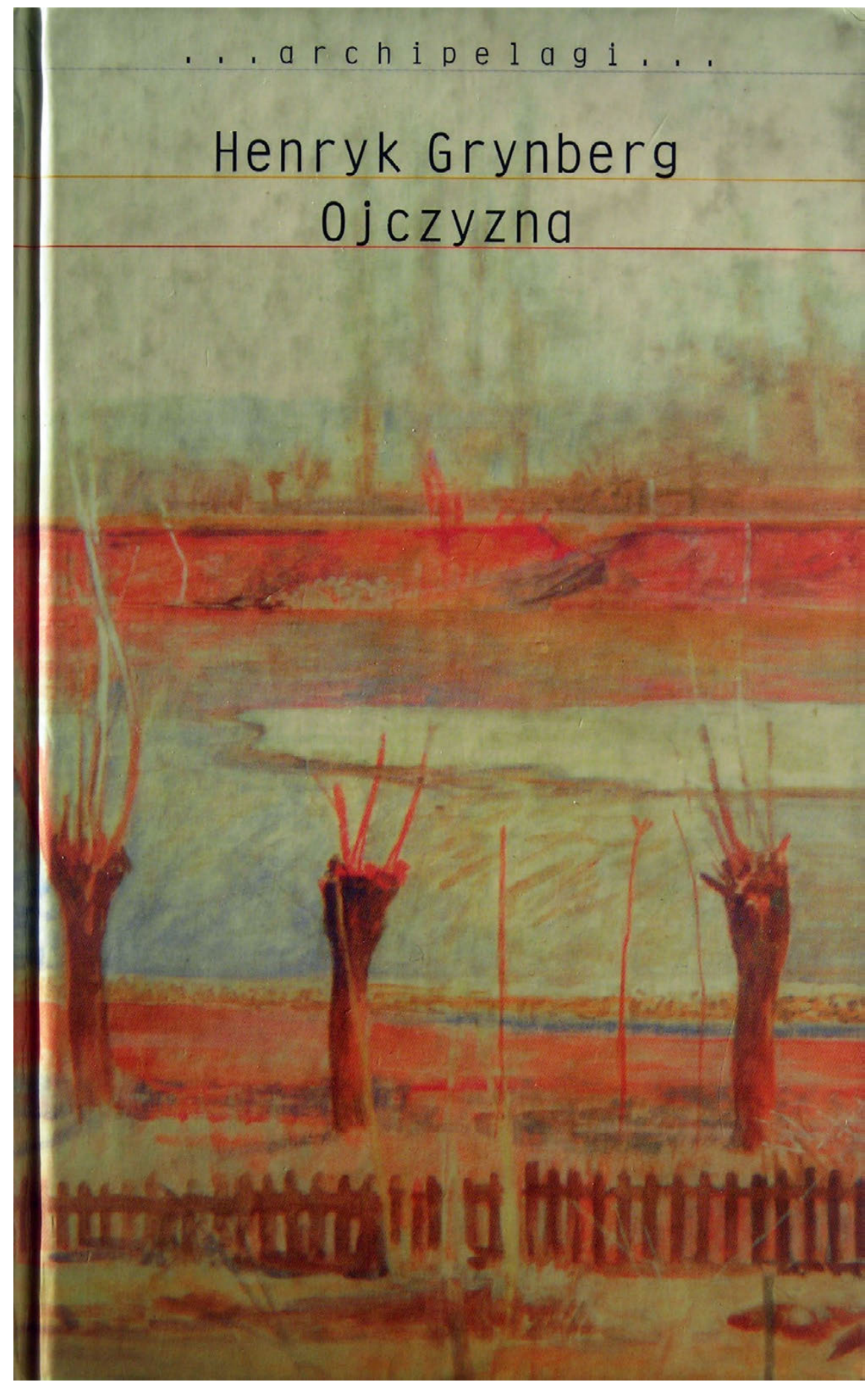

Wierzby z obrazu Jacka Malczewskiego Krajobraz znad Wisły (1904) na okładce książki Henryk Grynberga, Ojczyzna (Grynberg, 1999). Projekt okładki Maciej Sadowski (fot. Elżbieta Janicka)

Trudno natomiast oprzeć się wrażeniu, że kret wyłania się tutaj prosto z wiersza Biedny chrześcijanin patrzy na getto (1945) Czesława Miłosza, bocian zaś z hymnu, a właściwie hymnicznego lamentu Zu Pojln (1946) Abrahama Suckiewera, w którym istotną rolę odgrywają bociany pochodzące z Hymnu o zachodzie słońca na morzu (1863) Juliusza Słowackiego. Bocian to również ptak istotny dla judaizmu, na co wskazuje jego nazwa własna, a mianowicie chasyda, w liczbie mnogiej chasydim. Interesujące, że krasula - producentka mleka „polskiego z natury” czuje się w obowiązku opowiedzieć zarówno przed kretem, jak i przed bocianem 


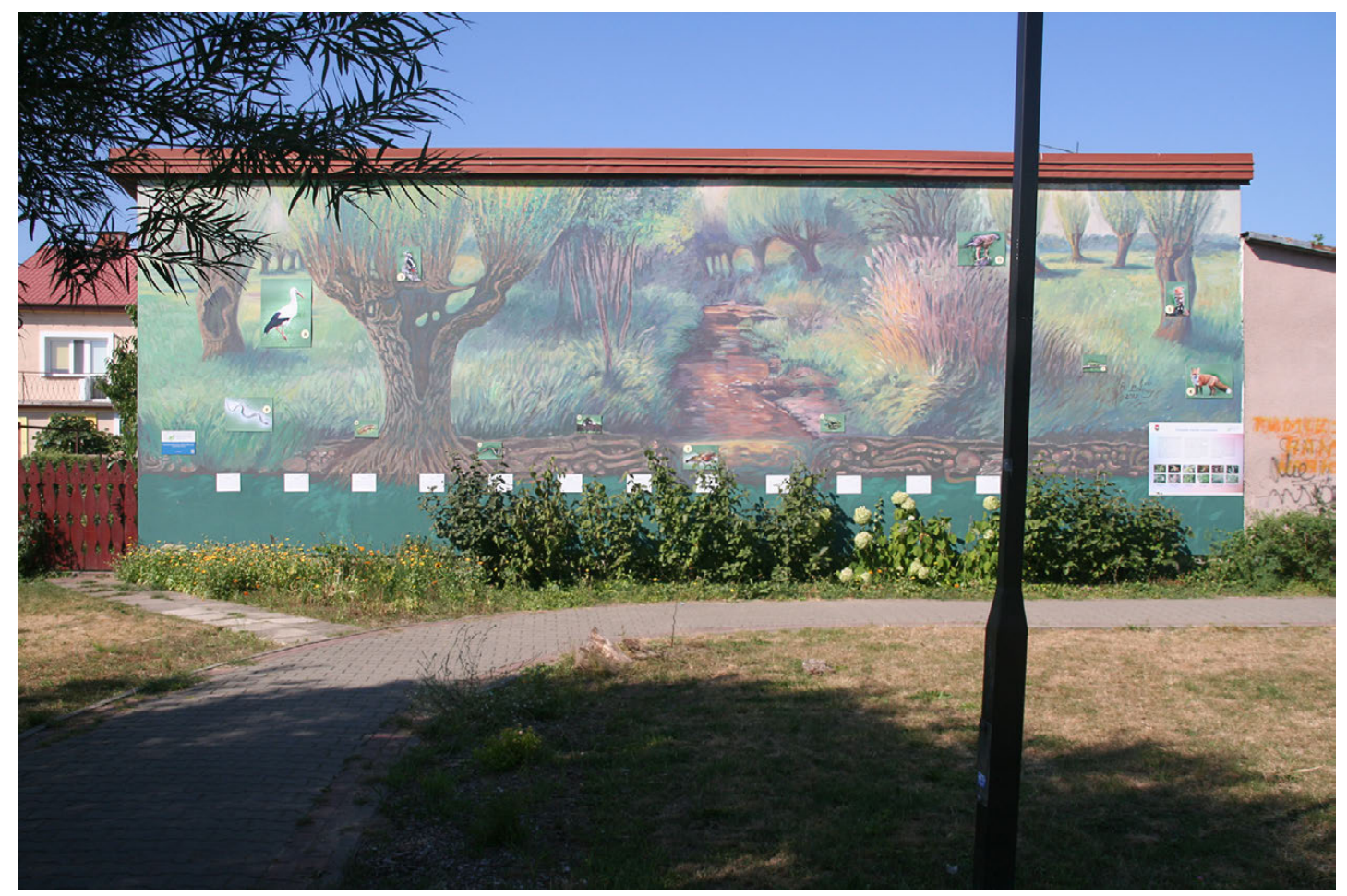

Mural zatytułowany Znaczenie wierzby w przyrodzie za dawną synagogą. W lewym górnym rogu gałęzie wierzby rzeczywistej - Kosów Lacki, 22 sierpnia 2020 (fot. Elżbieta Janicka)

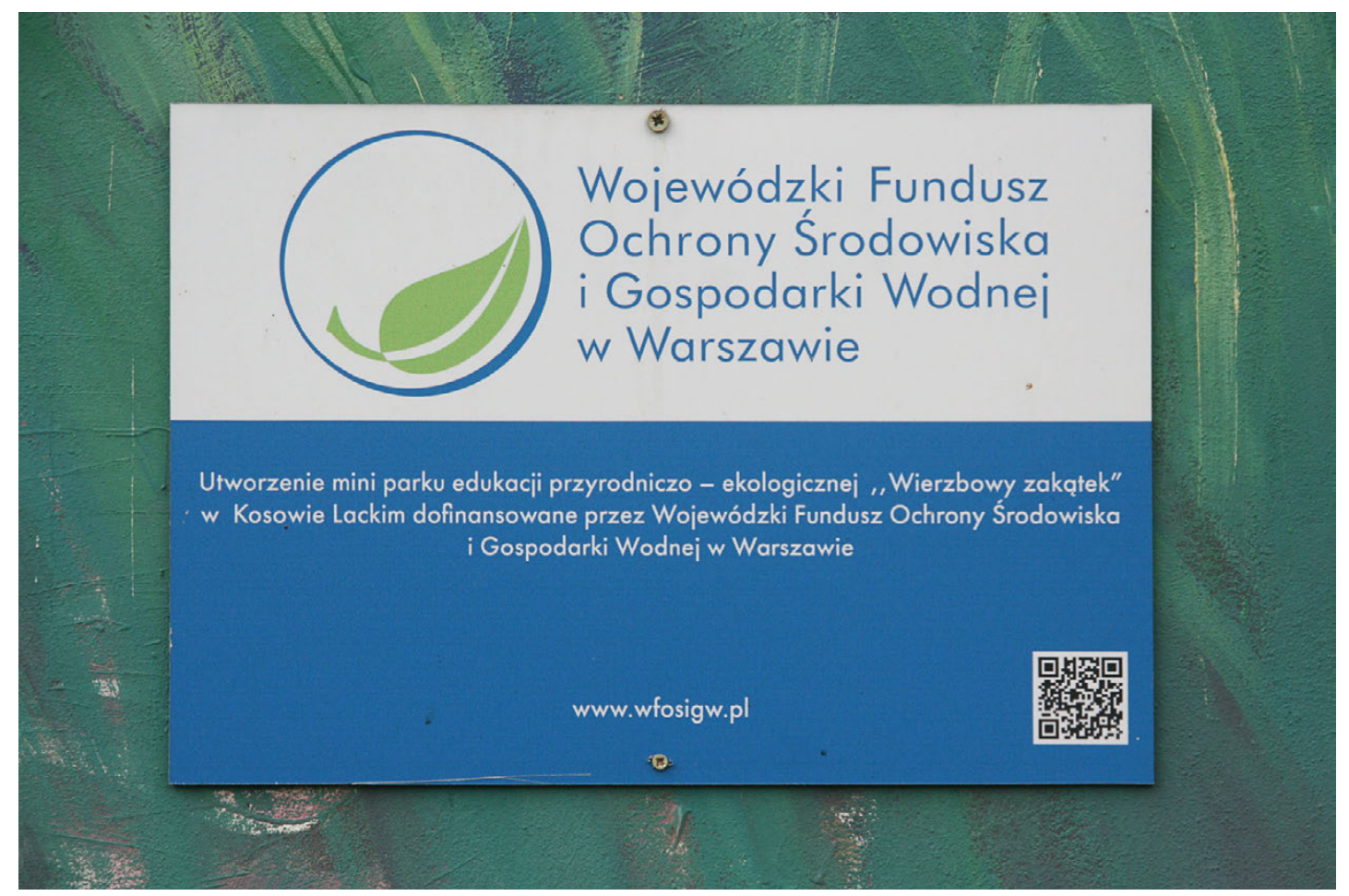

„Utworzenie miniparku edukacji przyrodniczo-ekologicznej «Wierzbowy zakątek» w Kosowie Lackim dofinansowane przez Wojewódzki Fundusz Ochrony Środowiska i Gospodarki Wodnej w Warszawie" - Kosów Lacki, 22 sierpnia 2020 (fot. Elżbieta Janicka) 


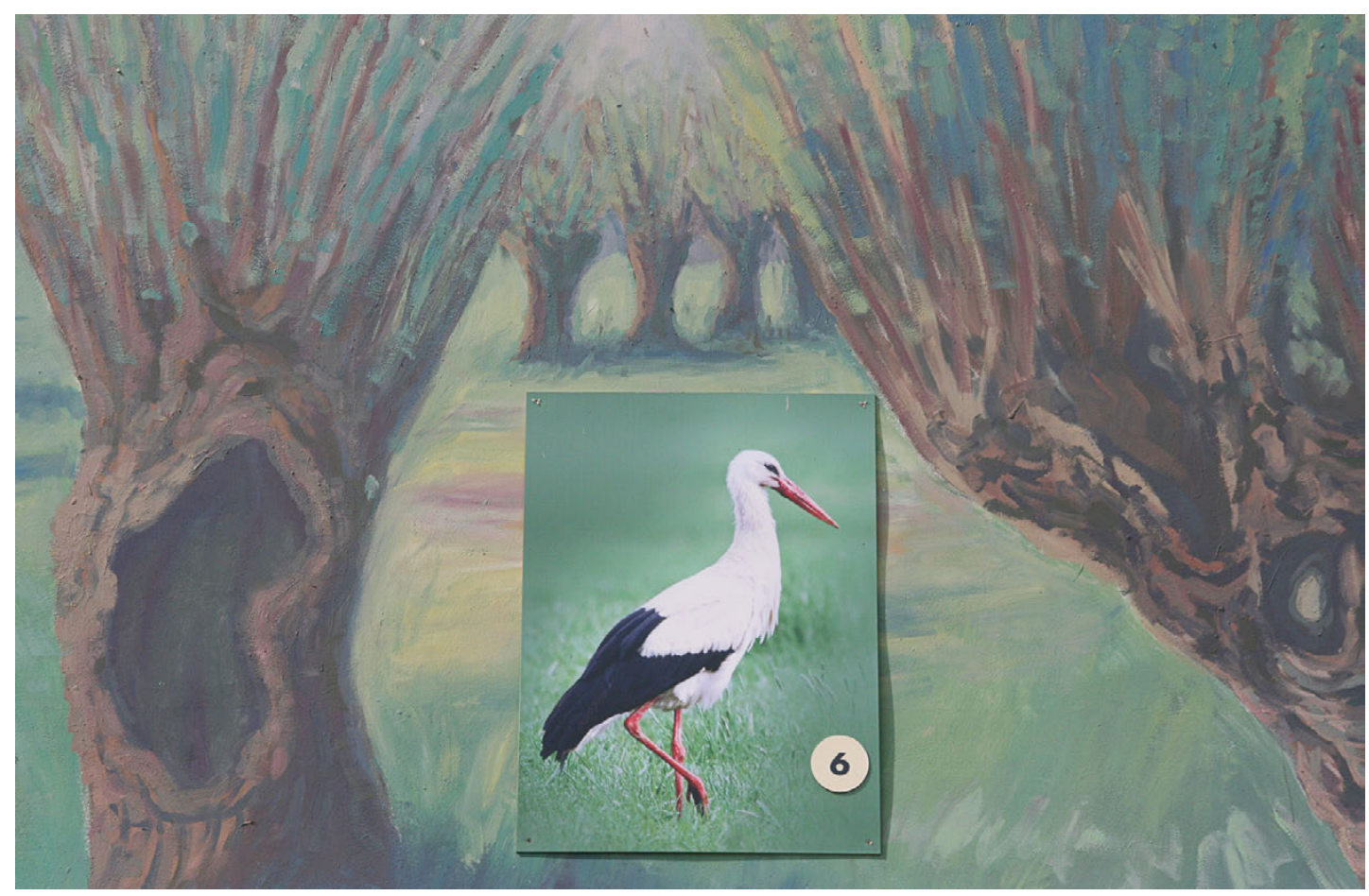

Fragment muralu Znaczenie wierzby w przyrodzie - Kosów Lacki, 28 sierpnia 2020 (fot. Elżbieta Janicka)

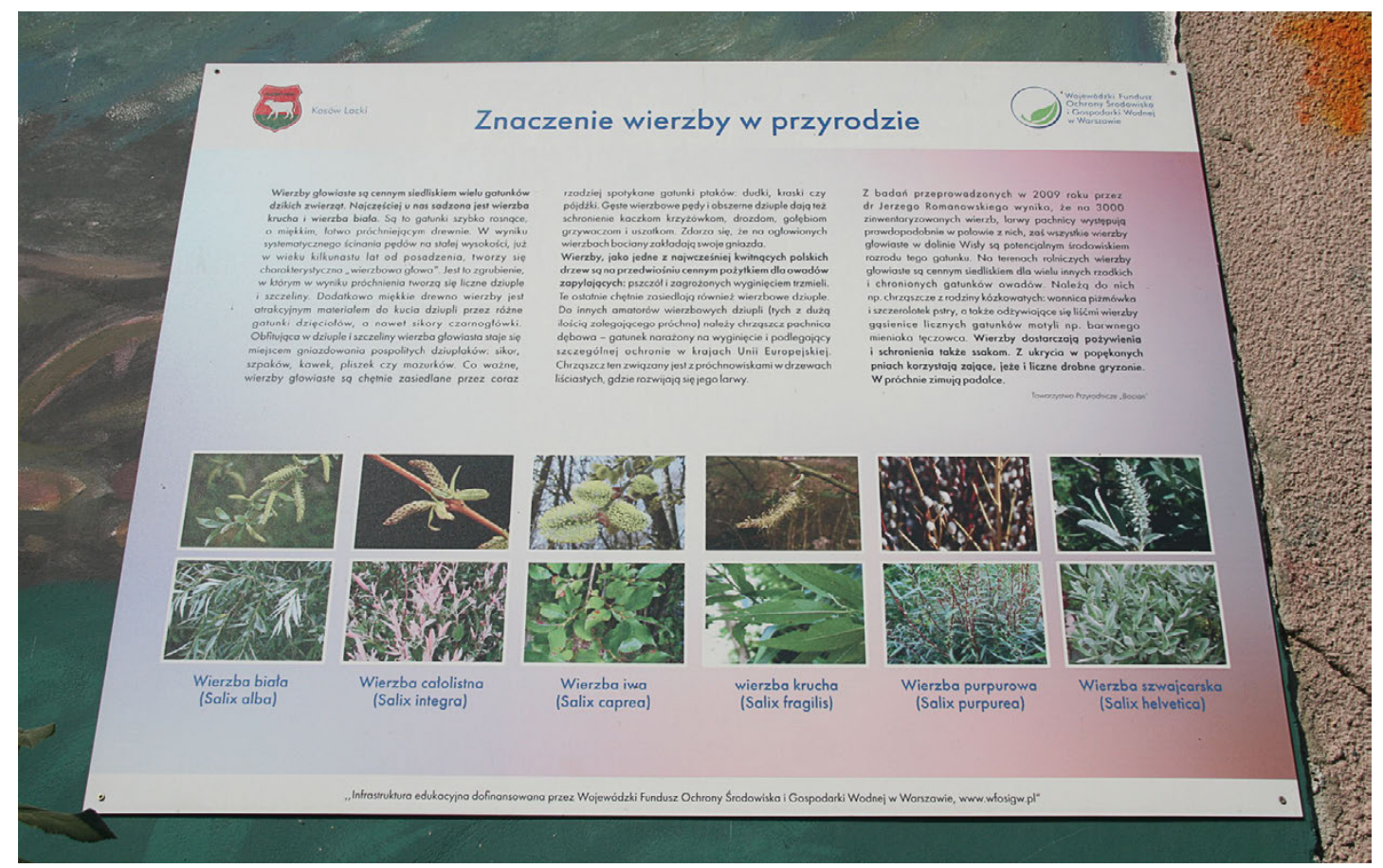

Tablica informacyjna Znaczenie wierzby w przyrodzie autorstwa Towarzystwa Przyrodniczego „Bocian” - Kosów Lacki, 22 sierpnia 2020 (fot. Elżbieta Janicka)

„Wierzby głowiaste są cennym siedliskiem wielu gatunków dzikich zwierząt”. Chodzi między innymi o ptaki niejednokrotnie będące już na wymarciu. „Wierzby, jako jedne z najwcześniej kwitnących polskich [sic!] drzew, są na przedwiośniu cennym pożytkiem dla owadów zapylających. [...] Wierzby dostarczają pożywienia i schronienia także ssakom. Z ukrycia w popękanych pniach korzystają zające, jeże i liczne drobne gryzonie. W próchnie zimują padalce".

Poza jednoznacznym stwierdzeniem tożsamości narodowej wierzby nie ma tu żadnych fantazmatycznych treści 


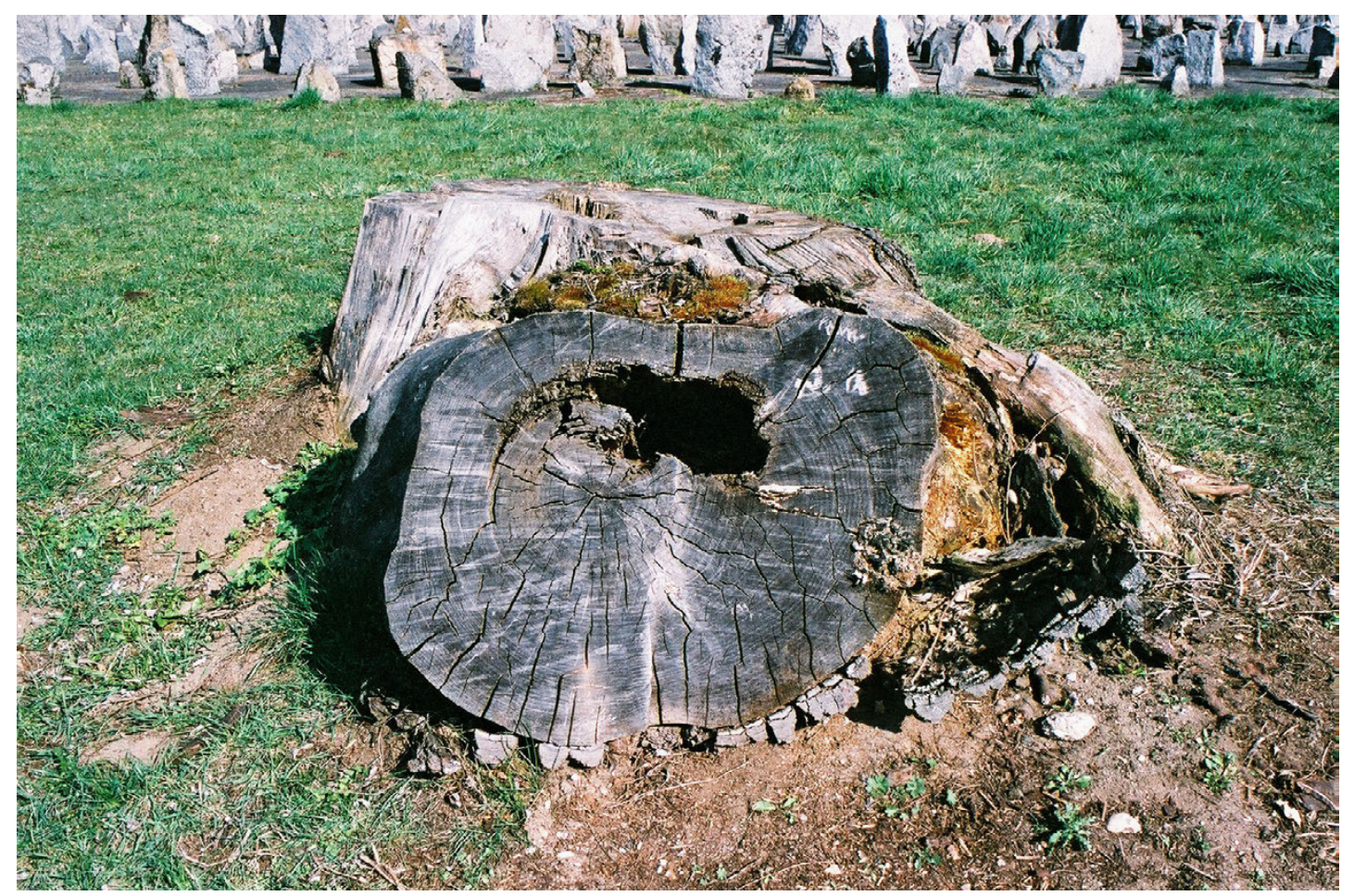

Pień wierzby obalonej przez huragan w nocy z 6 na 7 sierpnia 2010 roku - Treblinka II (d. Totenlager),

4 kwietnia 2014 (fot. Elżbieta Janicka)

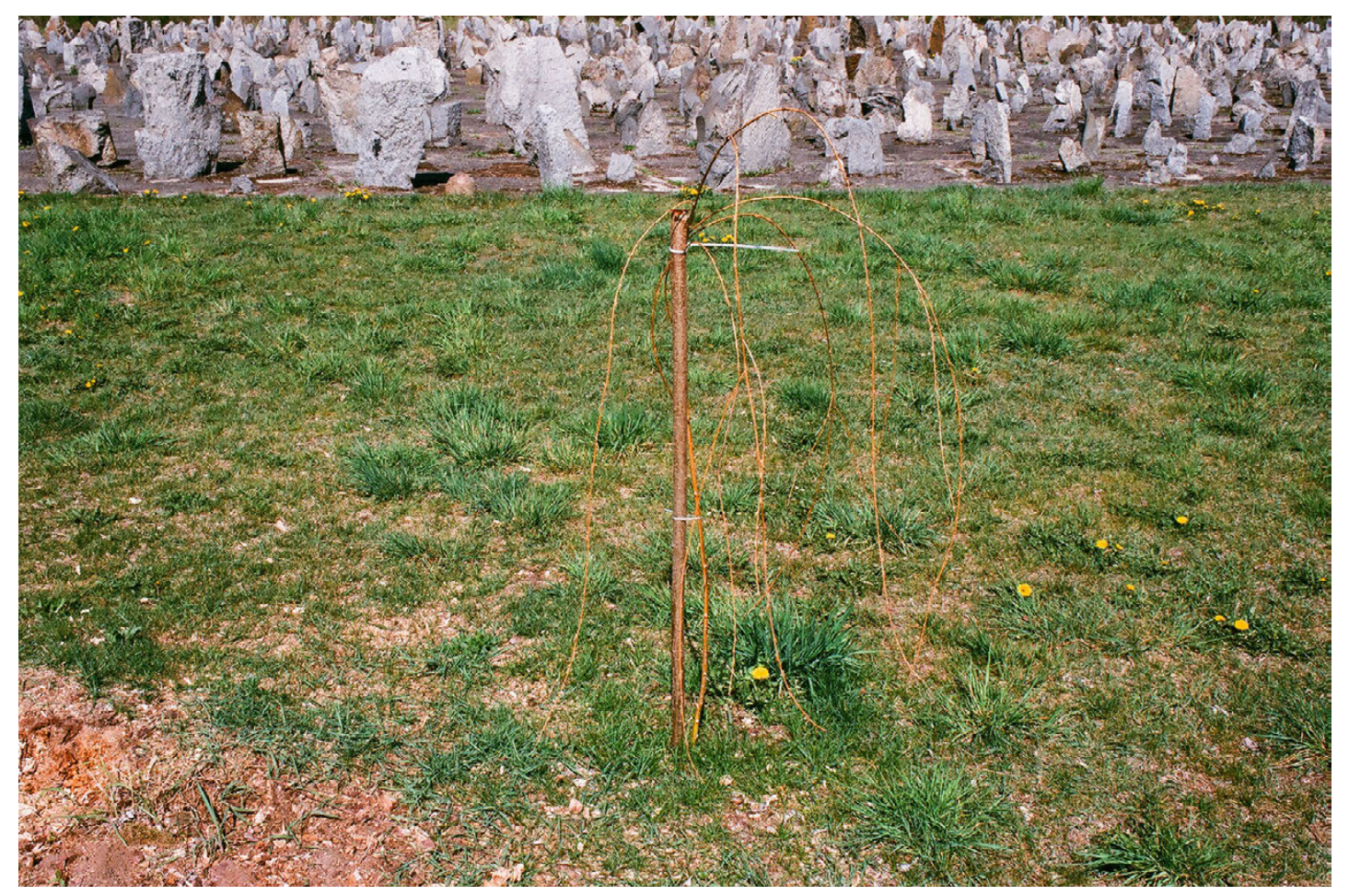

Wierzba nowo posadzona - Treblinka II (d. Totenlager), 26 kwietnia 2019 (fot. Elżbieta Janicka) 


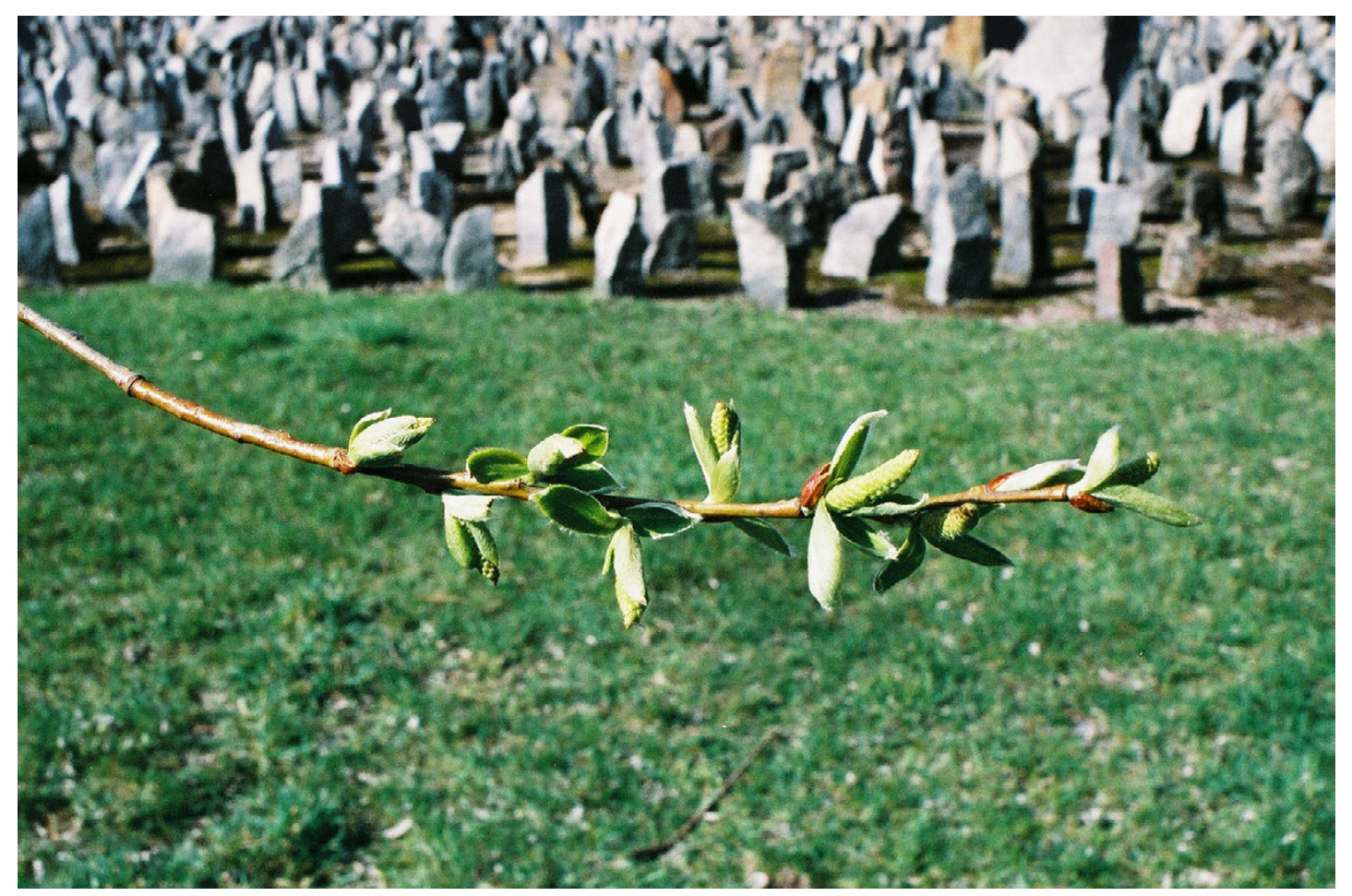

Gałąź wierzby - Treblinka II (d. Totenlager), 4 kwietnia 2014 (fot. Elżbieta Janicka)

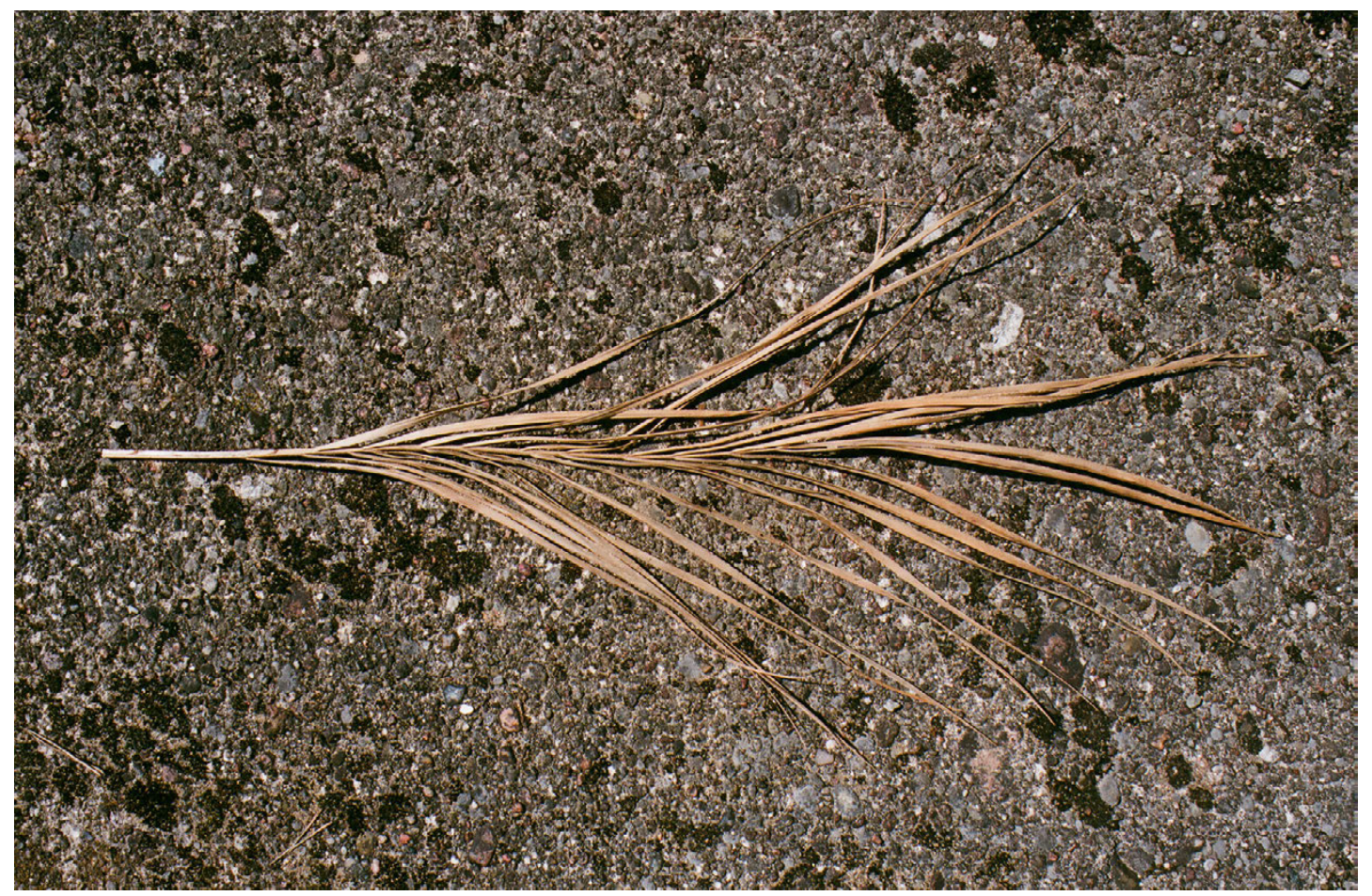

Liść palmowy odpadły od wieńca - Treblinka II (d. Totenlager), 13 lipca 2019 (fot. Elżbieta Janicka) 
potrafią być projektowane w sposób samoświadomy, by wyrażać cnoty danej wspólnoty spotecznej lub politycznej (Schama, 1995, s. 15) ${ }^{28}$.

A zatem wiedziałam o sposobach naturalizowania kulturowych konstruktów takich jak naród. Uczyłam się o antysemickiej mowie nienawiści wykorzystującej organiczną retorykę. Zgłębiałam całą tę antysemicką propagandę pełną botanicznych i zoologicznych toposów. Blut und Boden, jasne, że znałam. Jednakże Profesor była antropolożką kulturową badającą kulturę i społeczeństwo współodpowiedzialne za Zagładę, w łonie których Zagłada miała miejsce. Nie wątpiłam, że mordercze imaginarium, główne narzędzie zbrodni, było szeroko rozpowszechnione, że nigdy nie pozbawiono go prawomocności, że go nigdy nie zwalczano. A jednak. Wierzyłam (ufałam?) w hipokryzję. W zakłamany - klasowy i klasistowski - modus operandi inteligencji polskiej. Byłam w błędzie.

W encyklopedii Państwowego Wydawnictwa Naukowego znalazłam pod „endemiczny”: „przeciwieństwo... kosmopolitycznego”. Przykłady organizmów uważanych za nieendemiczne? (Kosmopolityczne organizmy, b.d.). Myszy. Szczur wędrowny. Mucha robaczyca. Wszy. Droga od Hortus Judeorum do Herbarium Polonorum została przebyta. Zamyst i zadanie Zielnika - ustanowione.

\section{Natura}

\section{Patrz pod „kultura”}

Jak dalece zieleń była częścią samego miejsca, a do jakiego stopnia - częścią projektu upamiętnienia, jeśli w ogóle? Opis techniczny sporządzony przez Danutę Oppenheim - przynajmniej ten, który zachował się w archiwum Adama Haupta - dotyczy wyłącznie Treblinki I i postuluje nasadzenia brzozy oraz jałowca. Co się tyczy Treblinki II, skłaniam się ku przekonaniu, że Oppenheim wzięła pod uwagę stan zastany - czyli wierzby - nie proponując większych zmian. Taki był duch szkoły myślenia, z której wydaje się wywodzić cały zespół projektowy: pozwolić na ekspresję miejscu jako takiemu, przy minimum interwencji czy organizacji. Jakkolwiek było: zieleń jest. I cała jest kulturową produkcją. Rodzajem mise-en-scène. In-scenizacją konceptów czy typów idealnych (Max Weber), takich jak las, łąka, odludne, odizolowane miejsce. Z których żaden nie koresponduje z tym, czym Treblinka w istocie była.

28 Zob. także Edensor, 2002, 2004. Niestety, Schama unika wszelkiej krytyki polskich narodowych mitów krajobrazowych. Sporządzony przez niego opis założenia pomnikowego w Treblince przyjmuje za punkt odniesienia upamiętnienia polskiego męczeństwa z rąk radzieckich, które zaczęły się mnożyć po 1989 roku. Należy do nich założenie pomnikowe w Gibach: „Niezliczone groby [Treblinki], niczym pomnik w Gibach, są oznaczone stojącymi nieobrobionymi kamieniami" (zob. Schama, 1995, s. 26). Schama wydaje się sugerować, że projekt dla Treblinki (1955) naśladuje projekt dla Gibów (1991), podczas gdy jest dokładnie na odwrót. Struktura tego zestawienia powiela antysemicki wzór zrównania „dwóch totalitaryzmów” fundujący tak zwaną teorię dwóch ludobójstw (double genocide theory). (W 2017 roku do głazów w Gibach dodano krzyże. Stało się tak za zgodą autora pierwotnego projektu Andrzeja Strumiłły). 
Kilka uwag na temat ostatniego z wymienionych pojęć. Nasadzenia zostały przeprowadzone w terenie - czy raczej nałożone na teren - po 1964 roku, w następstwie wzniesienia „pomnika”. Niektóre z nich najprawdopodobniej dopiero po premierze Shoah Claude’a Lanzmanna, która miała miejsce w 1985 roku. U Lanzmanna bowiem - prócz majestatycznej defilady krów mlecznych przez tory kolejowe - można podziwiać niespieszny travelling po kartoflisku, które na oczach widzów przechodzi w rząd głazów bez fazy pośredniej. Chodzi o kamienie wzdłuż południowej granicy byłego obozu. Istotnie bowiem granica obozu od wschodu i od południa biegła w poprzek pól uprawnych.

Franciszek Ząbecki, zawiadowca stacji kolejowej we wsi Treblinka oddalonej od Treblinki II o pięć kilometrów (zob. też Ząbecki, 1977), i Berek Rojzman, ocalały z Treblinki II, rozmawiając z Gittą Sereny, byli w tej sprawie jednomyślni:

- [...] Uprzedzano nas, że wchodzenie w strefę przyobozową jest zakazane i że znajduje się ona pod strażą. Niemniej jednak była tam droga, która przechodziła tuż obok obozu - wokół obozu ciągnęły się pola należące do miejscowych rolników, którzy... owszem... obrabiali je przez cały czas istnienia obozu. A więc obszar ten nigdy nie byt tak bardzo zakazany i ściśle strzeżony, jak by się wydawało.

(„O tak - powiedział Berek Rojzman - pracowali tam cały czas”. - W takim razie widzieli wszystko, co się tam działo?", zapytałam. Obaj, on i pan Ząbecki, wydawali się zaskoczeni moim zdziwieniem. „Oczywiście, że widzieli - odpowiedzieli. - Pracowali tam całymi dniami”) (Sereny, 2002, s. 131) $)^{29}$.

Według komendanta Treblinki II:

[S]etki żołnierzy i cywilów przychodziło do bramy, wystawało wzdłuż płotów, gapiło się i próbowało coś od nas kupić, gdyż powszechnie było wiadomo, że tyle dobra tu się poniewiera. Czasami nad obozem lot zniżały samoloty, aby zobaczyć, co tu się dzieje. Zadzwoniłem w tej sprawie do kwatery głównej i powiedziano mi, abym do nich strzelał. Zaczęliśmy strzelać i loty ustały. Lecz nigdy nie udało nam się skończyć z wizytami. Ludzie widzieli martwych Żydów na ziemi, widzieli, jak zabierano ich ze stacji do obozu. Robili zdjęcia. Smród obozowy czuć było dookoła z odległości paru kilometrów. Po wizycie w obozie wielu mówiło, że przez dwa tygodnie nie mogli niczego przełknąć (Sereny, 2002, s. 208).

To skłania mnie, by myśleć, że zieleń została dodana ex post w charakterze zasłony, celem wyprodukowania retrospektywnego efektu odizolowanego, odludnego miejsca.

127 tysięcy hektarów ziemi musiało zostać prawnie wywłaszczonych, by możliwe było powstanie oficjalnego państwowego upamiętnienia. Rekompensaty za wywłaszczenie przedstawiały sobą czterdzieści procent całkowitego kosztu realizacji. „[D]ziałki wykupiono od 192 właścicieli pochodzących ze wsi Grądy, Prostyń, Wólka Okrąglik i Maliszewa Nowa" (Zawadka, 2015, s. 39). Jak również Poniatowo. Już sam ten fakt uzmysławia, że Treblinka II - wyjąwszy ścisłą delimitację terytorialną obozu i obozu w obozie (Totenlager) - nie była miejscem odizolowanym i odludnym. Nie tylko w sensie przestrzennym zresztą. Jedną z nieustających trosk „panów sytuacji” (Władysław Szlengel) było maskowanie obozu przed spojrzeniem użytkowników pobliskiej drogi relacji Małkinia

29 Sereny przybyła na miejsce w 1972 roku wraz z Berkiem Rojzmanem (ocalałym), Franciszkiem Ząbeckim (w czasie wojny kolejarzem i członkiem Armii Krajowej), Wandą Jakubiuk (tłumaczką) oraz anonimowym kierowcą. 


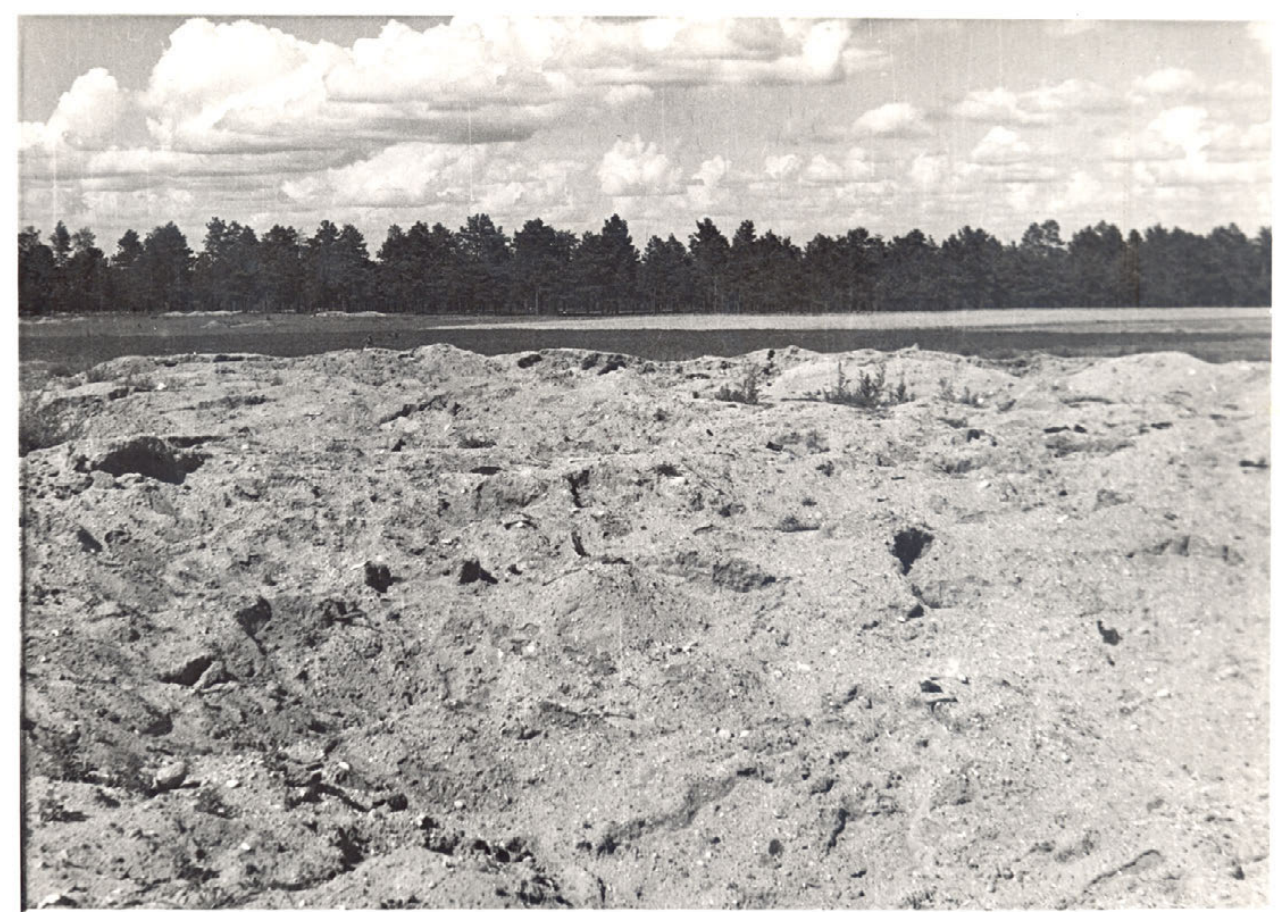

Wzorcowa poetyka Heimatphotographie zastosowana do obszaru byłego obozu zagłady Treblinka II. Widok z wnętrza strefy śmierci (Totenlager) z eksploatowanymi prochami na pierwszym planie. Druga połowa lat czterdziestych XX wieku (zdjęcie wykonane przez nieznanego fotografa towarzyszącego jednej z ekspedycji Centralnej Żydowskiej Komisji Historycznej; ze zbiorów Żydowskiego Instytutu Historycznego im. Emanuela Ringelbluma w Warszawie)

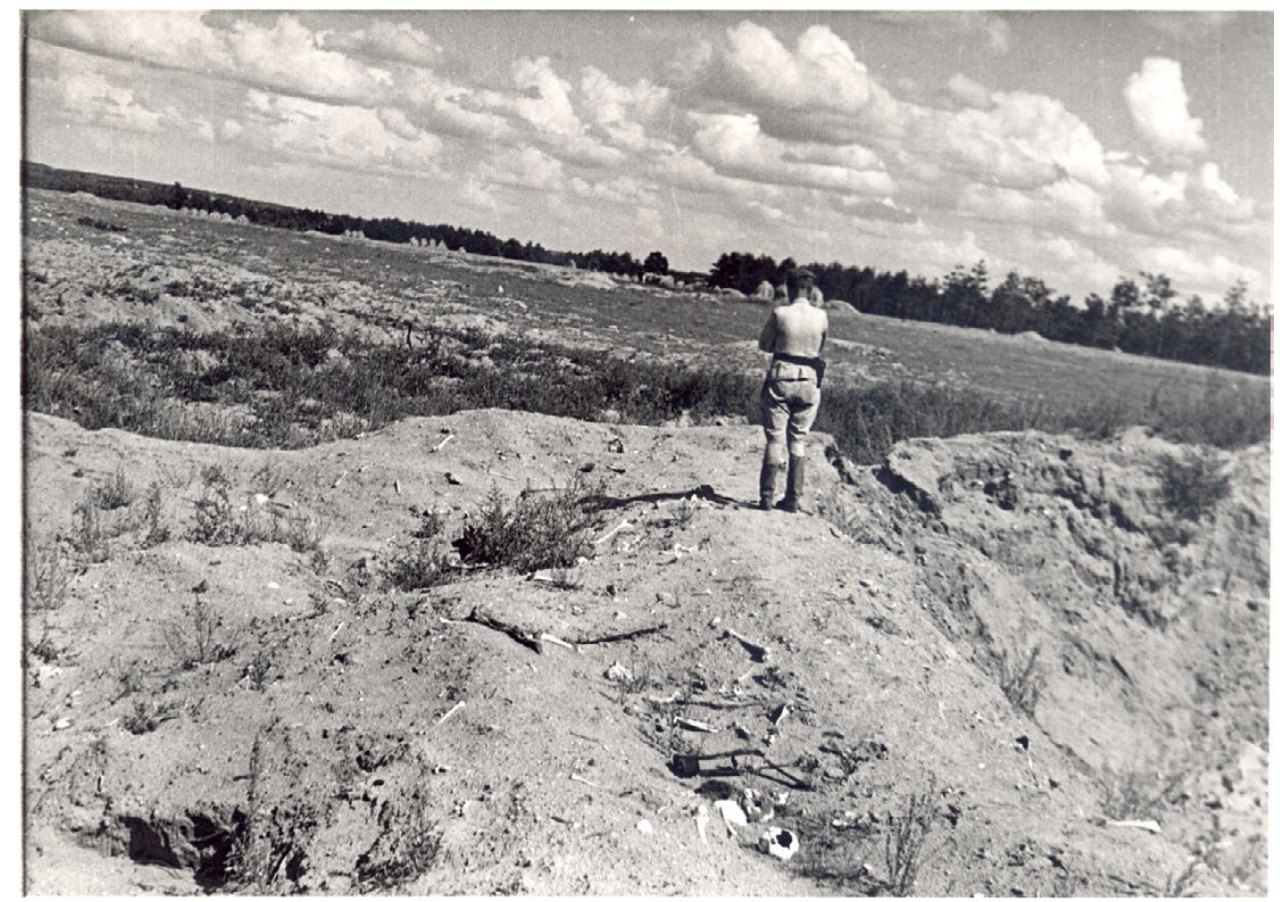

Uzbrojony żołnierz towarzyszący jednej z ekspedycji Centralnej Żydowskiej Komisji Historycznej patrzy na snopki na polach ze sterty eksploatowanych prochów z widocznymi czaszkami i kośćmi. Druga połowa lat czterdziestych XX wieku (zdjęcie wykonane przez tego samego fotografa, co powyżej; ze zbiorów Żydowskiego Instytutu Historycznego im. Emanuela Ringelbluma w Warszawie) 


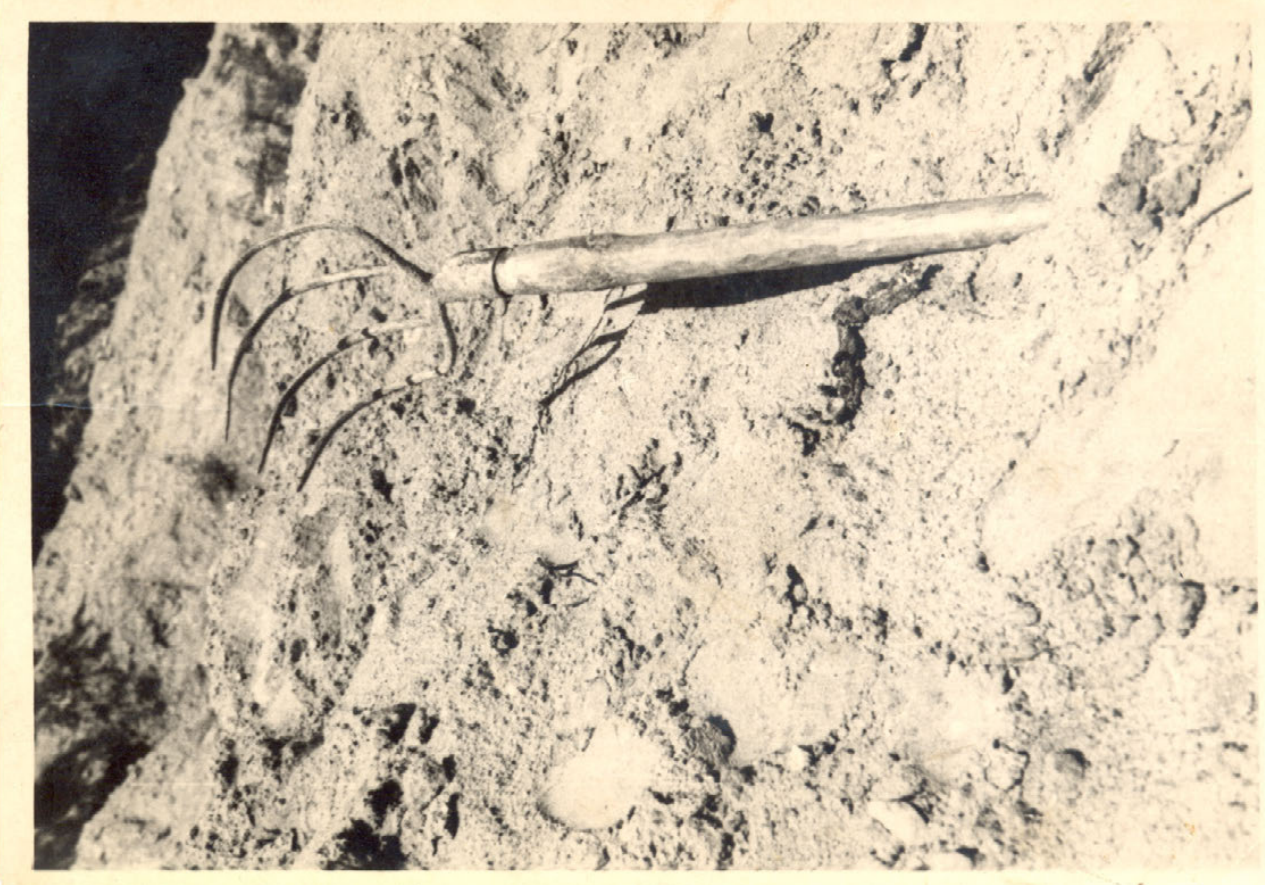

Podpis na rewersie (ołówkiem): „Treblinka / pierwsza komisja / ofiarodawca / pani Roma Byczuk” (fot. NN; ze zbiorów Żydowskiego Instytutu Historycznego im. Emanuela Ringelbluma w Warszawie)

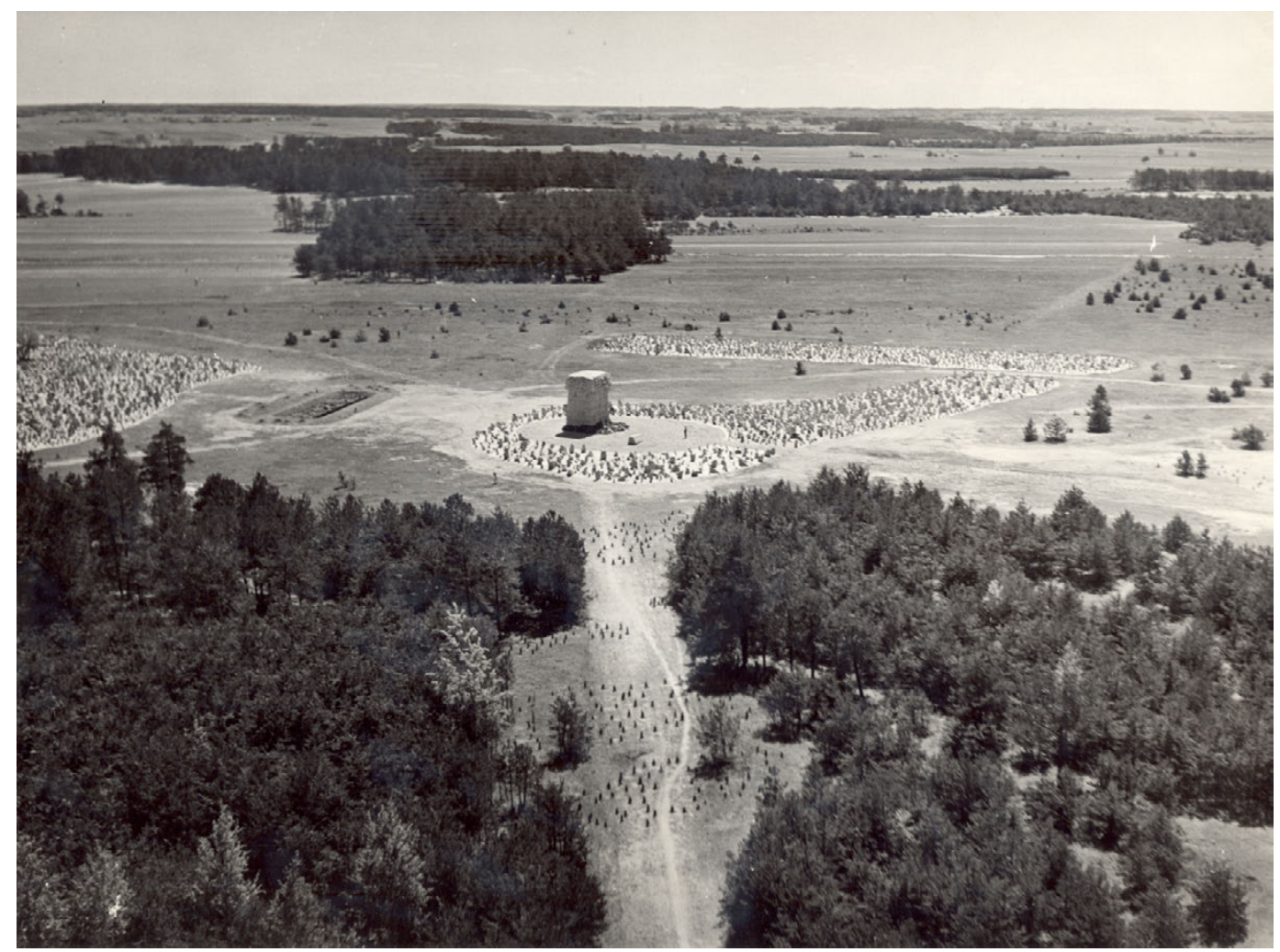

Teren byłego obozu zagłady Treblinka II w 1964 roku po ukończeniu kompleksu upamiętniającego. Przed „obiektem centralnym”, na jego osi, widoczna ludzka sylwetka dająca wyobrażenie o skali i proporcjach całości założenia. Widać także otwarty charakter otoczenia części zwanej Totenlager (fot. Franciszek Fuchs: ze zbiorów Żydowskiego Instytutu Historycznego im. Emanuela Ringelbluma w Warszawie) 
- Kosów Lacki (prowadzącej z Ostrowi Mazowieckiej do Sokołowa Podlaskiego), a też i przed spojrzeniem pasażerów pociągów z oficjalnego rozkładu, jeżdżących po torach kolejowych położonych między drogą a obozem, równolegle do drogi. Taki był zamiar, który nigdy nie został uwieńczony sukcesem.

System maskujący stosowano wszakże przede wszystkim wobec ofiar. Nigdy jednak nie on był wystarczająco gęsty ani wystarczająco wysoki. W późniejszym okresie także z uwagi na ogień i dym. Co zaś można było próbować ukryć przed wzrokiem, nie mogło zostać zatajone przed węchem i słuchem. Abraham Jakub Krzepicki był więźniem Waldkommando, które wychodziło do pracy na zewnątrz obozu i dostarczało materiału Zaunkommando odpowiedzialnemu za kamuflaż. Po ucieczce z Treblinki do getta warszawskiego w 1942 roku zeznat:

Powietrze przesączone było smrodem i krzykami. Kilometr od obozu niósł się podejrzany smród gnijących ciał, palonego mięsa, do uszu robotników z lasu dochodziły głosy kobiet i dzieci, jak krzyki ptaków, jak kwiczenie świń w rzeźni. Często zdawało się nam, że słyszymy głębokie, męskie krzyki, jakby wycie, ryczenie wołów w rzeźni (Krzepicki, 2017, s. 126).

Według śledztwa, które przeprowadził na miejscu Wasilij Grossman, krzyk mordowanych był słyszalny w sąsiedniej wsi Wólka Okrąglik. „[P]rzerażający, przeszywający, świdrujący kości, czaszkę, duszę”. „[P]rzeszywający, świdrujący mury, niebo i ziemię” (W. Gros[s]man, 1945, s. 19).

Franciszek Ząbecki mówit, że także transporty były słyszalne z daleka: „Nie z powodu odgłosów charakterystycznych dla jadącego składu, tylko z powodu ludzkich krzyków i strzałów" (Sereny, 2002, s. 131). Niezliczone świadectwa potwierdzają, że zwłoki Żydów rozciągały się wszędzie wzdłuż torów wiodących do Treblinki, jak na fotografiach Huberta Pfocha. Pfoch, austriacki socjalista i żołnierz Wehrmachtu, udokumentował masakrę Żydów na stacji kolejowej w Siedlcach (70 kilometrów od stacji kolejowej w Treblince) 22 sierpnia 1943 roku. Prócz tego zanotował w prowadzonym wówczas dzienniku:

Kiedy w końcu odjechaliśmy ze stacji - pisał Pfoch - wzdłuż torów leżało przynajmniej pięćdziesiąt martwych ciał kobiet, mężczyzn i dzieci, niektóre były zupełnie nagie. [...] Nasz pociąg jechał z[a] transportem i dalej widzieliśmy ciała po obu stronach torów - również dzieci. Mówili, że Treblinka jest „obozem do odwszawiania”. Kiedy zbliżyliśmy się do stacji Treblinka, transport znajdował się tuż obok nas. Fetor leżących wokół stacji i rozkładających się zwłok powoduje, że niektórzy z nas wymiotują. Słychać coraz głośniejsze błagania o wodę i coraz więcej bezładnej strzelaniny strażników... (Sereny, 2002, s. 137).

\section{Parametry niewymierne}

Treblinka nie była miejscem odludnym i odizolowanym także ekonomicznie i aksjologicznie. „Henryk ze łzami w oczach wyznał mi tej nocy, że grając w pokera między dwoma transportami przegrał pięćdziesiąt tysięcy dolarów, sumę wtedy fantastyczną" (Lanzmann, 2010, s. 457) 30 - mówi Claude Lanzmann o Henryku Gawkowskim, polskim

30 Nic z tego nie przedostało się do filmu Lanzmanna. Jednocześnie na plakat zwiastujący Shoah reżyser wybrał kadr z portretem Gawkowskiego, zreprodukowany następnie na okładce wersji DVD. 
maszyniście z Małkini, członku chóru kościelnego tamże, który doprowadzał transporty do bram Treblinki II i dalej - we wnętrzu obozu - do rampy wyładowczej. Jak ujął to Richard Glazar, ocalały:

Cała okolica stoi na głowie, a gdzieś pośrodku, w piachach i lasach nad zakolem Bugu, króluje Treblinka.

Tutaj ciągną spekulanci nawet z odległości 100 kilometrów. Ale przyłapany przez gorliwego wachmana włóczęga, który bojaźliwie kryje się między drzewami, jest tylko ostatnim ogniwem całego łańcucha. Wielcy spekulanci siedzą w domu, w Warszawie albo Lublinie, gdzie ponoć powstały całe organizacje wysyłające swoich ludzi z załadowanymi pojazdami do chałup wokół Treblinki. Cała okolica wzdłuż i wszerz pasożytuje na tej wielkiej rzeźni skażonej mamoną. Wszystkim zależy, żeby Treblinka istniała nadal i pozostawiała swój cenny produkt uboczny - pieniądze, złoto, diamenty (Glazar, 2011, s. 110).

Dokładnie te same mechanizmy działały w odniesieniu do getta warszawskiego i innych gett, jak również do Zagłady w ogóle. „Inaczej mówiąc: Żydzi byli okradani przed Zagładą, podczas Zagłady i po Zagładzie" (Kwiet, 2019, s. 57).

Inną częścią tej samej kwestii jest kwestia spożywcza. Była ona widoczna gołym okiem i jawna od samego początku. Jak wyraził się Calel Perechodnik w liście do żony rok po tym, jak została zagazowana w Treblince wraz z ich córką:

Tak, wiem doskonale, ciało Twoje, przecudne Twe ciało, tylekroć przeze mnie całowane, Niemcy spalili i zużyli jako nawóz naturalny. Może na Twoim popiele wyrosły kartofle, które akurat ja spożywam, może wyrosło żyto, z którego chleb akurat ja jem.

Nie chcę o tym myśleć, inaczej zwariowałbym szybko, ale chcę i muszę o tym myśleć [...] (Perechodnik, 2004, s. 256).

Perechodnik pisał swój list 19 sierpnia 1943 roku, zanim zaczęła się długofalowa polska eksploatacja i handel żydowskimi prochami. Polacy także „chcieli i musieli o tym myśleć", choć z innej perspektywy. Tak więc zasłona zieleni skrywa także to: najintymniejsze z możliwych splecenie uczestników morderstwa z zamordowanymi.

Jednakże liczne oznaki zadają kłam starannie wypracowanej iluzji fizycznej izolacji. Przeszłej i obecnej. W końcu lipca kombajny blokują leśne drogi i przez cały dzień robię zdjęcia w ich ogłuszającym łomocie. Wiosną i jesienią leśne aromaty mieszają się z zapachem obornika użyźniającego pola przysłonięte drzewami. Godne odnotowania jest interesujące odwrócenie. Podczas gdy w przeszłości tym, co bez powodzenia maskowano gałęziami drzew, był obóz, tym co bez powodzenia maskuje się gałęziami drzew obecnie, są pola uprawne. Również przydrożne znaki zakazu zbierania grzybów wyglądają bardziej niż wymownie. Pojawiają się w lesie każdego roku w drugiej połowie sierpnia. Wraz z zagorzałymi grzybiarzami.

Jeśli za kolejne elementy ciągu uznać naturę w stanie pierwotnym, przekształcenia - w tym usuwanie - natury i ponowne wprowadzenie natury w miejsce, gdzie jej chwilę przedtem nie było, pełna przepychu natura Treblinki byłaby tym trzecim. Wyróżnia ją jednak odrębność jakościowa. Różnica istoty. Dodanie zieleni wewnątrz i wokół obszaru 


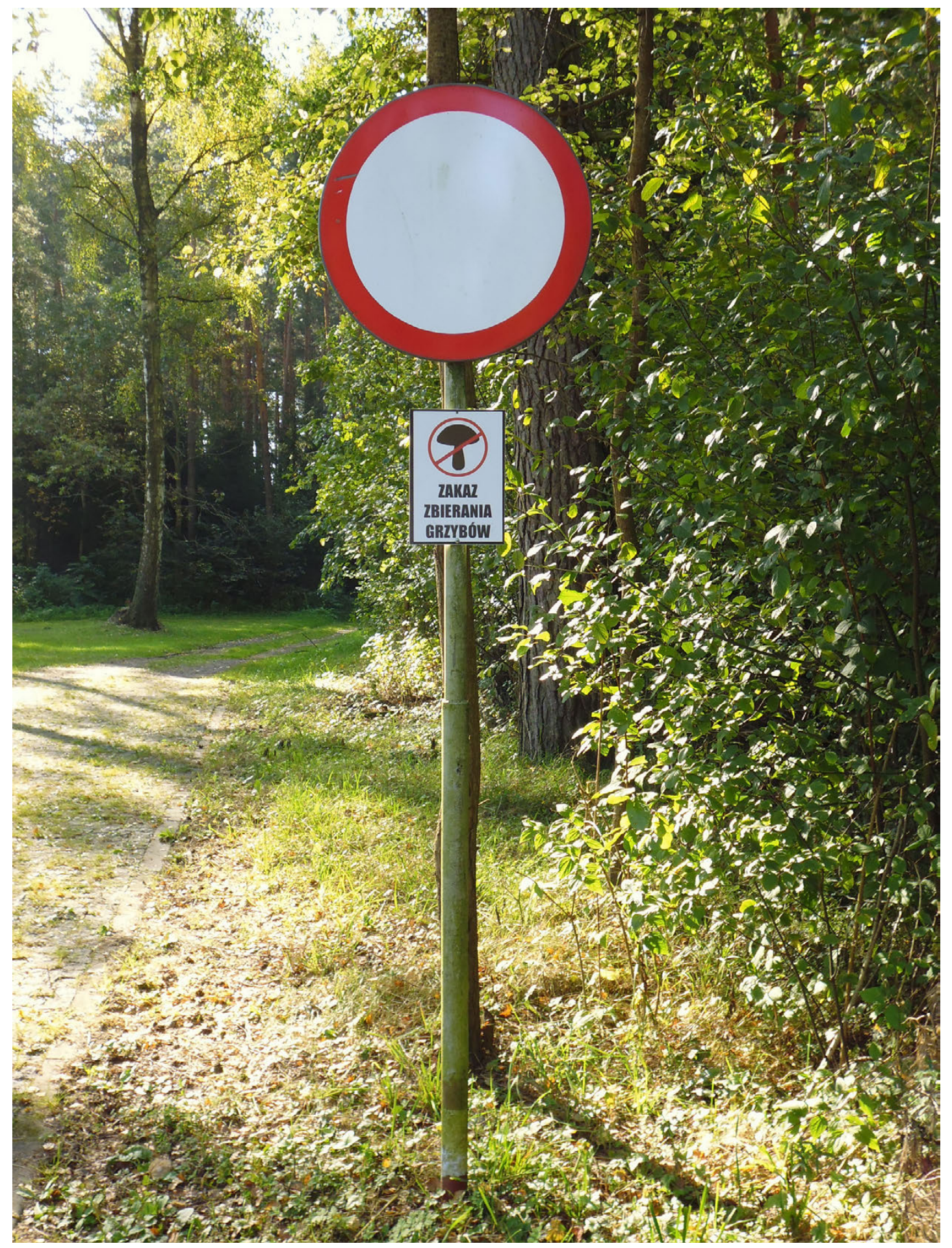

Znak zakazu zbierania grzybów - Treblinka II, 7 września 2014 (fot. Elżbieta Janicka) 


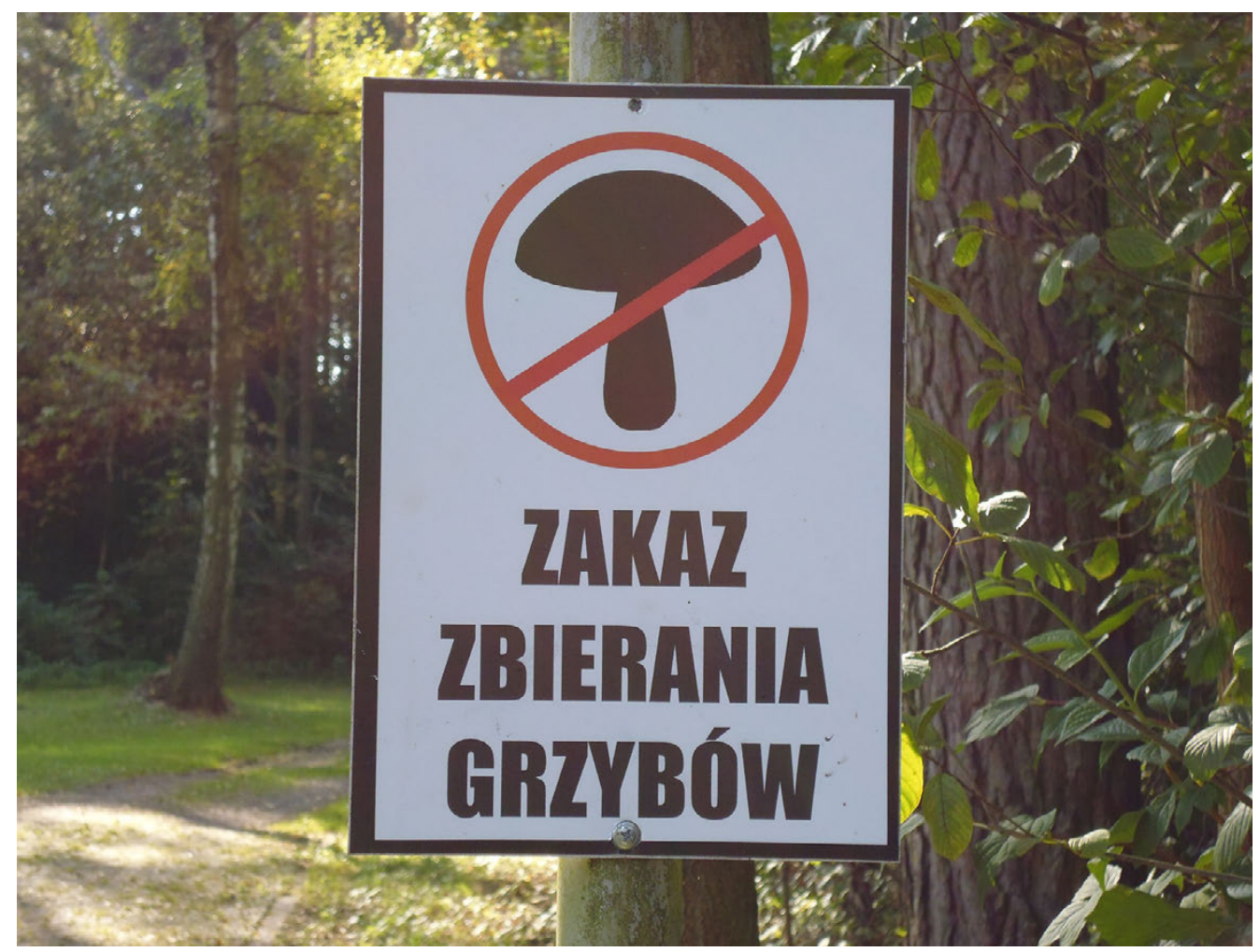

Treblinka II, 7 września 2014 (fot. Elżbieta Janicka)

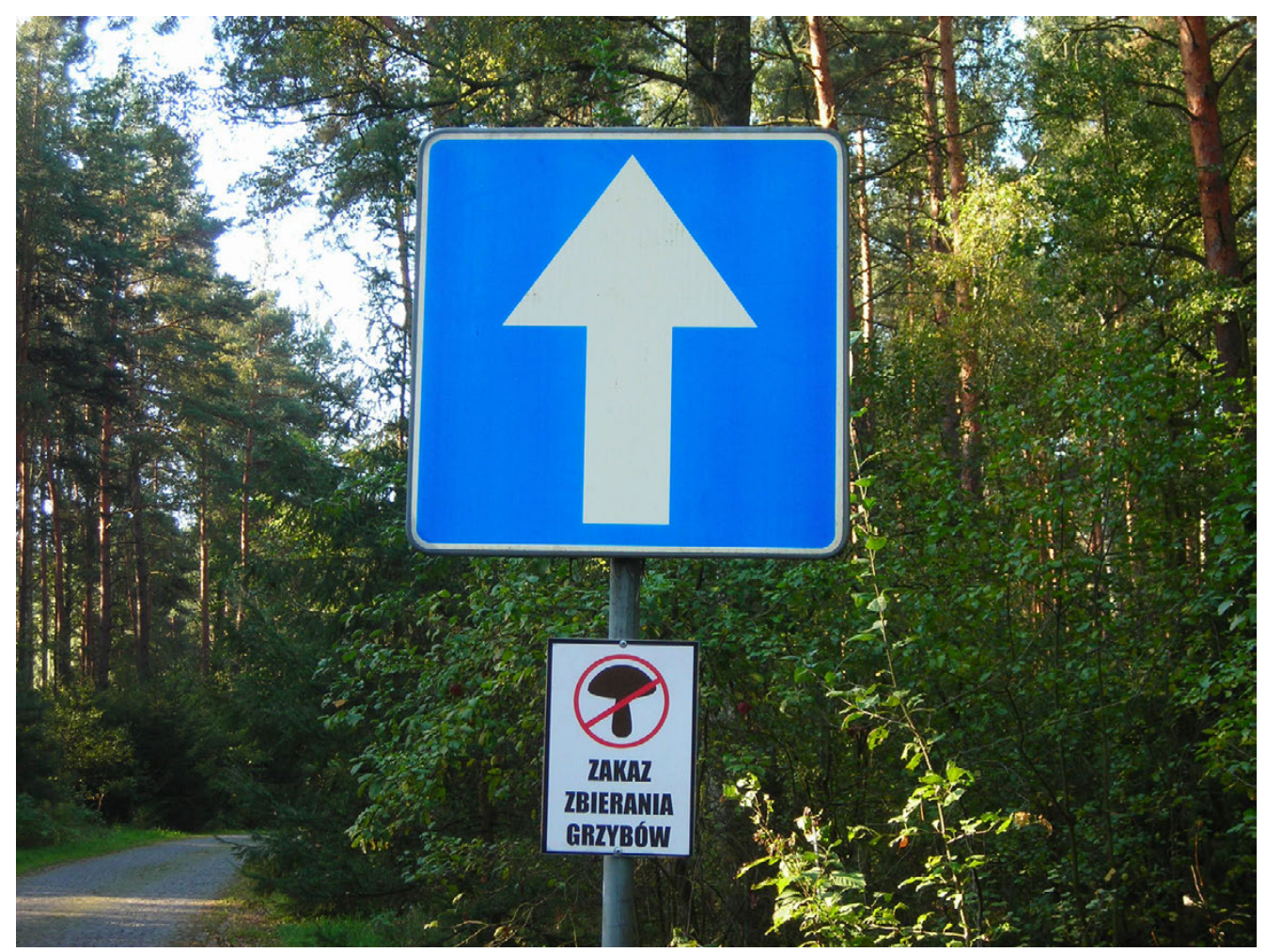

Treblinka II, 7 września 2014 (fot. Elżbieta Janicka) 


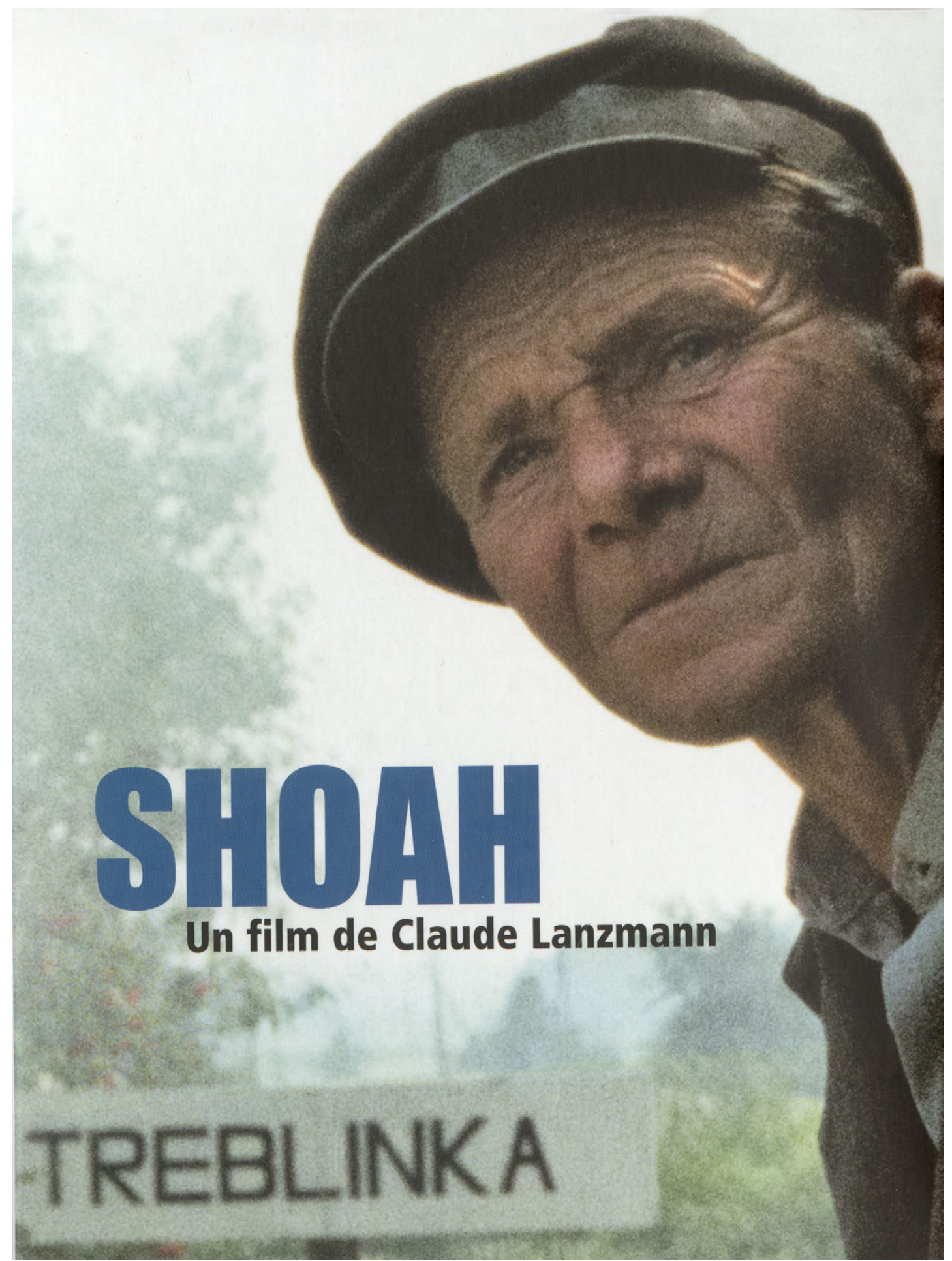

Oryginalny plakat filmu Claude’a Lanzmanna Shoah (1985) zreprodukowany na obwolucie DVD. Kadr filmowy przedstawia Henryka Gawkowskiego, maszynistę kolejowego z Małkini, który wprowadzał transporty śmierci do wnętrza Treblinki II (fot. Elżbieta Janicka) 
dawnego obozu Treblinka II zwieńczyło bowiem proces profilowania, antropogeniczną transformację terenu całkowicie antropogenicznego. Zieleń była tu ostatnim gwoździem do braku trumny.

Krajobraz kulturowy może być rozumiany jako realny, materialny obiekt. Jedna z jego definicji brzmi: „Krajobraz kulturowy to krajobraz naturalny przetworzony przez grupę kulturową. Kultura jest czynnikiem, krajobraz naturalny - medium, a rezultatem krajobraz kulturowy" (Sauer, 2014, s. 35). Nie przystaje to do rozważanego przypadku. Kultura, owszem, była tutaj czynnikiem, a krajobraz kulturowy rezultatem, wszelako medium stanowił... również krajobraz kulturowy. Był to krajobraz podwójnie antropogeniczny. Po pierwsze, został on wyprodukowany przez ludzi. Po drugie, został on wyprodukowany z ludzi. Nie ludzi jakichkolwiek, lecz kulturowo skategoryzowanych i posegregowanych. Z jednej strony Austriacy, Niemcy, Ukraińcy, Polacy jako podmiot. Z drugiej strony Żydzi jako przedmiot. Natura Treblinki jest zatem podwójnie złożonym kulturowo rodzajem natury. Naturą podwójnie kulturowego pochodzenia. Kulturą jako naturą. Ze wszystkimi tego konsekwencjami. Wszelkie próby odnoszenia się do tego faktu czy rozważania go w zdepolityzowany sposób są - nomen omen - gruntownie nieprawomocne.

\section{Naturgarten}

Klasyfikacja jest podstawą idealnej tożsamości grupowej, w której ramach grupa zostaje przeciwstawiona przeciwgrupie ${ }^{31}$. Przeciwstawienie to jest częstokroć naturalizowane i przekładane na kategorie moralne.

Pożytek z klasyfikacji - poczucie bezpieczeństwa wynikające z umocnienia poczucia tożsamości - odczuwany jest najsilniej właśnie wtedy, gdy wskazane zostanie uosobienie różnicy. W toku polskiej historii $\mathrm{W}$ tej funkcji zawsze występowali Żydzi, od średniowiecza o r g a n i z a t o r z y polskiego systemu dystynkcji (Tokarska-Bakir, 2008, s. 632).

Chrześcijański system klasyfikacji, oddzielający to, co własne/obce, użyteczne/bezużyteczne, czyste/nieczyste, nałożyt się w Europie na klasyfikacje archaiczne, wyznaczające zarówno tu, jak i wszędzie indziej nie tylko „to, co dobre do jedzenia”, ale przede wszystkim „to, co dobre do myślenia" (Tokarska-Bakir, 2008, s. 349).

Ów system elementarnych klasyfikacji wyznaczał chrześcijański sposób myślenia o sobie jako „Człowieku” i o Żydach jako kimś pomiędzy „Drugim Człowiekiem” a „Człowiekiem Niebędącym W Pełni Człowiekiem” (Tokarska-Bakir, 2008, s. 349)32. „Nosicielem i reproduktorem klasyfikacji, za pomocą których Grupa opisuje siebie i świat, jest jej język wypełniony metaforami. Działają one przez dyskretne, ale sugestywne skojarzenia

31 „Afirmacja Grupy dokonuje się tu przez wychwalanie jej «czystości», do czego najlepiej prowadzi ukazanie jej zaprzeczenia - Antygrupy. [...] Gwarancję bezpieczeństwa Grupy stwarza jej oddzielenie od Antygrupy przeprowadzane w planie osadniczym, w obiegu produktów żywnościowych i w wymianie matrymonialnej" (Tokarska-Bakir, 2008, s. 345).

32 Joanna Tokarska-Bakir podsumowuje w tym miejscu wyniki badań przedstawione w pracy Kennetha Stowa, Jewish Dogs. An Image and its Interpreters. Continuity in Catholic-Jewish Encounters (Stow, 2006), Claudine Fabre-Vassas, La bête singulière. Les juifs, les chrétiens et le cochon (Fabre-Vassas, 1994), Antona Bloka, Honour and Violence (Blok, 2001). 
w celu przeforsowania swych szczególnych definicji rzeczywistości” (Tokarska-Bakir, 2008, s. 347).

Co najmniej na tym samym poziomie co język - jeśli nie na poziomie ramowym umieściłabym imaginarium. W każdym razie nie ma znaczenia bez wartości. Semiotyczne jest aksjologiczne. I to aksjosemiotyczne dzierży prym.

Krajobrazy są kulturą, zanim staną się naturą; konstruktami wyobraźni projektowanymi na las i wodę, i skałę. [...] Powinno być jednak także przyjęte do wiadomości, że gdy tylko pewne wyobrażenie krajobrazu, mit, wizja usadawiają się w konkretnym miejscu, mają one szczególną zdolność zamulania kategorii, czynienia metafor bardziej rzeczywistymi niż ich desygnaty, stawania się de facto częścią pejzażu (Schama, 1995, s. 61).

I znacznie więcej niż tylko częścią. Ci, którzy doznali wstrząsu, widząc „drzewa swojego dzieciństwa" w Shoah, nie ujęliby tego lepiej. Tym, co ukazało się ich oczom, była ni mniej, ni więcej tylko Arkadia jako locus horridus. Dla ścisłości: tym, co zobaczyli, nie było wyjściowo idylliczne i swojskie miejsce następnie dopiero przekształcone w locus horridus, lecz miejsce z początku jedynie potencjalnie idylliczne i swojskie, które wymagało zbrodni, by stać się miejscem faktycznie idyllicznym i swojskim. Arkadia zakładała śmierć Żydów jako sam warunek swojej możliwości33. Jak wyraził się szlachcic, właściciel ziemski z Ceranowa tuż koło Kosowa Lackiego:

byt to żerujący na naszym organizmie obcy polip, którego wskutek naszego niedołęstwa nie potrafiliśmy się pozbyć. Operację przeprowadził Hitler [...]. Nie mogłem ukryć uczucia zadowolenia, gdy przejeżdżałem przez odżydzone nasze miasteczka i gdy widziałem, że ohydne, niechlujne żydowskie rudery z nieodłączną kozą przestały szpecić nasz krajobraz (Górski, nd., karta 74).

Zbawcza operacja polegała na przeprowadzeniu kategorialnego oczyszczenia w terenie. Klasyfikacja stała się ciałem. Razem z konceptualną czystością - przełożoną na naturalne i moralne kategorie - osiągnięte zostały piękno, zdrowie oraz idylliczna swojskość. Rzeczy znalazły się na swoim miejscu. To, co jest, stało się tożsame z tym, co powinno być. Ulga, której doświadcza polski szlachcic, przypomina ekstazę chiliastyczną. Zbawienie ma miejsce w sferze aksjosemiotycznej, która góruje nad rzeczywistością, pozbawiając ją wagi i znaczenia, nawet jeśli Górski opisuje również mordowanie Żydów i polski w nim udział.

Profesor z profesorsko-doktorskiej konwersacji podziela przekonanie, że - w rezultacie Zagłady - obce zostało usunięte ze swojskiego i zezłomowane w jednym wyraźnie odgraniczonym, wydzielonym miejscu. Wszystko - jak zawsze - przełożone na kategorie naturalne i moralne. Stąd szok uczonej w obliczu kwintesencji swojskości (wierzby) tam, gdzie spodziewała się kwintesencji obcości (palmy). Znajdujemy się oto w pośrodku wyobrażonego Naturgarten - naturalizacji narodu i unarodowienia natury.

33 Na temat Arkadii jako miejsca bukolicznej beztroski i miejsca paniki pierwotnej zob. Panofsky, 1955, 1971. 
Już w 1900 roku Willy Lange, jeden z czołowych teoretyków sztuki ogrodowej, wzywał do odnalezienia w architekturze ogrodowej „narodowego stylu”. Postulowany przez niego Naturgarten miał być projektowany w zgodzie z prawami natury. W latach trzydziestych jego poglądy były przesiąknięte ideologią rasistowską. Na łamach narodowosocjalistycznego czasopisma „Deutsche Kulturwacht” Lange przekonywat, że ogrody w stylu formalnym, charakterystyczne dla rasy alpejskiej, stanowią zagrożenie dla rasy nordyckiej. Twierdził również, że wyższy stopień rozwoju kulturalnego mogą osiągnąć tylko te ludy, które są zakorzenione w ziemi, w związku z tym ludy nomadyczne, takie jak Żydzi czy Romowie, nigdy nie osiągną takiego stopnia rozwoju jak Niemcy. [...] „Nasze ogrody - pisał - staną się niemieckie, jeśli idee planowania będą niemieckie, zwłaszcza jeśli będą one inspirowane krajobrazem, w którym ogród jest usytuowany" [cyt. za: Joachim Wolschke-Bulmahn, Gert Gröning, The National Socialist Garden and Landscape Ideal. Bodenständigkeit (Rootedness in the Soil), (w:) Art, Culture and Media under the Third Reich, edited by Richard A. Etlin (Chicago, IL: University of Chicago Press, 2002), s. 77]. [...] Ponadto, w ogrodach $w$ „stylu niemieckim” miały rosnąć wyłącznie rośliny uznawane za rdzennie niemieckie. Rośliny obcego pochodzenia mogły się w nich znajdować tylko wówczas, gdy przypominały wyglądem gatunki rodzime. Zabiegom tym służyła rozwijana od końca XIX wieku w Niemczech dyscyplina zwana „socjologią roślin”. W 1936 roku Albert Kraemer, jeden z jej propagatorów, przekonywał:

„Wciąż brakuje nam określonych rasowo ogrodów, które miałyby swe źródło w narodzie i krajobrazie, w krwi i ziemi. Tylko wiedza na temat rodzimej ziemi i jej świata roślin umożliwia nam i obliguje nas do projektowania zakorzenionych w krwi i ziemi ogrodów" [Joachim Wolschke-Bulmahn, Gert Gröning, The National Socialist Garden and Landscape Ideal..., op. cit., pp. 79-80] (Matczyński, 2018, ss. 68-69) 34. $^{34}$

Wierzba z profesorsko-doktorskiej konwersacji jest obiektem aksjosemiotycznym par excellence. Skoro - jako się rzekło - czystość wisi tu w powietrzu, nie zaszkodzi powtórzyć również, że profesorska wierzba jest czystym wyobrażeniem, fantazmatem. Jej kulturowa natura - by tak rzec - nie pozostawia wątpliwości. Skonstruowana i działająca przez zaprzeczenie wyobrażonej, fantazmatycznej palmie, jest ona elementem - jeśli nie emblematem - mentalnego i emocjonalnego systemu produkującego, legitymizującego i naturalizującego antysemickie wykluczenie oraz przemoc. Jest ona narzędziem zbrodni, unurzanym w żydowskiej krwi. Nic jej nie łączy zatem z fizycznie istniejącymi wierzbami, które rosną na środku Treblinki II w strefie śmierci (Totenlager). I wszystko ją z nimi łączy. I wszystko ją łączy ze wszystkim innym. Natura kulturowego pochodzenia została wyprodukowana przez aksjosemiotyczne, stąd nie może być oddzielona od aksjosemiotycznego.

Czyż nie jest Treblinka dzisiaj - czy nie jestże dzisiejsza Polska - spełnieniem, typem idealnym rasistowsko zdefiniowanego ogrodu mającego swe źródło w narodzie i krajobrazie, we krwi i ziemi? Wyjąwszy jedno. To mianowicie, że - wywodząc się z ambicji czystości kategorialnej - z czystością kategorialną nie ma ów ogród nic wspólnego. Wprost przeciwnie. Krew i ziemia, o których mowa, okazały się bowiem - a raczej stały się - żydowskie. Nici z „odżydzenia”. Stąd panika moralna prezentowana przez Profesor. Fundamentalna w swym rdzeniu. Dotycząca gruntu rzeczy. I jako taka stanowiąca temat mojej pracy. Jak to ujął Henryk Grynberg: „Polska bez Żydów? Już nigdy takiej nie będzie. Są w tej ziemi i powietrzu na zawsze. Polaków, którym trudno się z tym pogodzić, mogę

34 Por. także ogrodowo-krajobrazową bibliografię w książce Małczyńskiego. 
pocieszyć, że Żydom też nie jest łatwo" (Subbotko, 2011, s. 18). Podczas debaty jedwabieńskiej Polonia w Nowym Jorku robiła wszystko, co w jej mocy, wymachując apotropaicznymi sloganami: „Syjonistyczne bestie - Łapy precz od Polski”, „Mity o Holokauście kryją żydowskie zbrodnie”, „Żydzi zabili miliony Polaków”, „Zabierajcie z Polski swoje popioły" (Grynberg, 2012, s. 36) 35 . Daremnie.

\section{Kalos und kagathos}

Piękne i dobre. Piękne jako dobre. I na odwrót. Naturalizowane również. Zieleń w Treblince - w funkcji maskującej, zatajającej i dekoracyjnej - ma swoją wojenną historię. Pojęcie ogrodu koncentracyjnego zostało sformułowane przez Marcina Świetlickiego w latach dziewięćdziesiątych. (W analizowanym przypadku mamy do czynienia z ogrodem zagłady). Praktyka jednakże wyprzedzała konceptualizację o parę dziesiątków lat. Szeroko znane są nazistowskie plany miasta-ogrodu Auschwitz (zob. Czyżewski, 2001; Brüggemeier i in., 2005). Wszelako istniał także spontaniczny projekt ogrodowo-parkowy dla Treblinki II:

[R]ozkopują cały obóz. Wyciągają nawet ludzi z warsztatów i przydzielają ich do robót przy torach. Powstały nowe komanda, które pod obstawą opuszczają obóz i zwożą na ciężarówkach żwir, żużel i inne materiały budowlane. Kiedy przyjadą następne transporty, Treblinka będzie wyglądać jak piękny park - powiedziat ponoć ostatnio Lalka [Kurt Franz - zastępca komendanta, a potem komendant obozu - E. J.] (Glazar, 2011, ss. 107-108) ${ }^{36}$.

Jankiel Wiernik relacjonował, że wejście do nowych komór gazowych przyozdabiały „na stopniach [z] obu stron starannie ustawiane kosze z kwiatami” (Wiernik, 2003, s. 19). Jednakże ogrodnictwo w Treblince wykraczało poza funkcjonalną potrzebę zwodzenia ofiar. Oprócz warzywnika przy wschodniej granicy obozu (bliżej jej północnego krańca), w części zajmowanej przez sprawców znajdował się ogród kwiatowy otaczający ZOO:

Robiłem zagrodę z drzewa brzozowego. Był to niski parkan dookoła ogrodu kwietnego. Były w tym ogrodzie również zwierzęta i ptactwo. Dookoła było pięknie i spokojnie. Z drzewa zrobiono ławki dla wypoczynku dla niemców i ukraińców [ortografia oryginalna - E. J.]. Spokój i cisza zalegały to miejsce (Wiernik, 2003, s. 31).

\section{Richard Glazar:}

Klocki, z których zbudowano Treblinkę, tworzą szaloną mieszaninę form i barw. Nad bramą główną wisi wycięta z drewna kula ziemska i róża wiatrów. Nakładają się na nią dwa znaki runiczne SS. Budkę strażniczą zdobi artystyczna snycerka. [...]

35 „Patriotyczny polski pisarz nie mógłby dziś zatytułować swojej powieści Popioły, a tym bardziej Popiót i diament. Może więc okrzyk get your ashes out of Poland wyraża coś więcej niż ordynarny antysemityzm? Przed wojną antysemici (i nie tylko antysemici) byli przekonani,że Żydzi zagrażają polskiej tożsamości. I pod tym względem mało się zmieniło" (Grynberg, 2012, s. 38).

36 „W bydlęcych wagonach więcej trupów i półżywych niż kiedykolwiek przedtem. Nieliczni trzymają się na nogach. A jednak niektórych wybierają, żeby poprawić trochę stan zdziesiątkowanej załogi, żeby było więcej niewolników do wspaniałej rozbudowy obozu,żeby SS-Sonderkommando Treblinka mogło wykazać się rozległą działalnością, żeby droga następnych transportów z «dworca» do «łaźni» biegła wzdłuż ozdobnych rabatek przez parkowy skwer" (Glazar, 2011, s. 119). 
A jak wygląda otoczenie głównej rezydencji! Szarość wybrukowanych dróg wokół komendantury obramowują pobielone wapnem krawężniki. Obok dróg bocznych, wysypanych piaskiem o świetlistej żółtej barwie, widnieją mozaiki z kolorowych kamieni - prawdziwy kalejdoskop (Glazar, 2011, ss. 143-144).

Wrażliwość estetyczna i chłonność w obcowaniu z naturą zostały odnotowane w relacjach sprawców w ogólności, a sprawców „Zagłady od kul” (Patrick Desbois) w szczególności:

Wielu pamiętało widok drzew, roślin, kwiatów. Wspominali dźwięki i zapachy. [...] Jeden ze sprawców spędził jakiś czas, objaśniając sądowi trwałe wrażenie, jakie zrobił na nim konkretny kwiat (Kwiet, 2019, s. 46).

W niektórych okolicach, mordercy woleli do mordowania Żydów miejsca, które w dochodzeniach w sprawie zbrodni wojennych i na procesach opisywali jako Kuschelgelände, tagodnie falujące pochyłości - co tłumaczy się jako „kameralne”, „zaciszne”, a nawet „przytulne” (Kwiet, 2019 , s. 44).

Komendantem Treblinki II był Hauptsturmführer Franz Stangl, nazista austriacki, wcześniej jeden z wykonawców Akcji T4 oraz komendant obozu zagłady w Sobiborze. Stangl definiował się jako „katolicki oficer SS” (Sereny, 2002, s. 238 ). „Wyróżniony oficjalną pochwałą jako najlepszy komendant obozu w Polsce” (Sereny, 2002, s. 199), uwijał się w pocie czoła niczym istny Franz Budowniczy: „Zakładałem ogrody, budowałem nowe baraki, nowe kuchnie, wszystko nowe, zatrudniałem fryzjerów, krawców, szewców, stolarzy” (Sereny, 2002, s. 174). Znajdował upodobanie w „świeżych warzywach” z obozowego warzywnika - „Sami je hodowaliśmy” (Sereny, 2002, s. 148). Wspominał specjalnie kalafiory. Był dumny z Kurt-Seidel-Strasse, osiemsetmetrowej, dwupasmowej, betonowej drogi wybudowanej wewnątrz obozu z jego rozkazu pod jego oknami, podobnie jak z kwiatów i wiecznie zielonych krzewów, którymi ją obsadzono wiosną 1943 roku (zob. Ziesing, 2004). Dekady później nadal sławił powaby obozowego ZOO (sarna, lisy, gołębie, dwa pawie): „Było tam mnóstwo pięknych ptaków [...] oraz ławki i kwiaty. [...] Nie jest łatwo [...] teraz to wszystko opisać, lecz wyglądało to naprawdę pięknie" - wyznał (Sereny, 2002, s. 144). Po buncie więźniów „chciał odbudować Treblinkę, jeszcze piękniejszą niż kiedykolwiek przedtem" (Sereny, 2002, s. 217) ${ }^{37}$. Będąc kwestią klasyfikacji, piękno tkwi w oku patrzącego.

Nawiązując do koncepcji ogrodu zagłady, zdecydowanie nie podpisuję się pod wywodem Zygmunta Baumana z Nowoczesności i Zagłady. Bauman łączy ideę ogrodnictwa i logikę ogrodu z nowoczesnością, którą z kolei obciąża odpowiedzialnością za eksterminację osób z niepełnosprawnościami i za eksterminację Żydów ${ }^{38}$. Bauman nie wziął

37 Umiłowanie, jakie Stangl żywił dla piękna natury, towarzyszyło mu w dalekiej Brazylii: „Różowo-biały dom z jasnymi kwiatami na podwórku wygląda, jakby był przeniesiony z austriackiego krajobrazu. [...] Na ścianie bawialni wisi ładny obraz z austriackim pejzażem, na telewizorze postawiono wazon z suchymi kwiatami górskimi" (Sereny, 2002, s. 33).

38 Wywód Baumana jest również kontrfaktyczny, ponieważ według nazistowskich architektów ogrodowych, orędowników „endemicznie germańskiego” Naturgarten: „Powstałe w tym duchu ogrody miały się cechować nieregularnością oraz dopasowywać się do otaczającego je krajobrazu. Wycinanie i podcinanie roślin traktowano jako przejaw antropocentryzmu i z tego powodu czynności te były zabronione” (Małczyński, 2018, s. 69). Ogrody 
pod uwagę, że eksterminacja osób z niepełnosprawnościami wzbudziła sprzeciw Kościołów chrześcijańskich i została przerwana, podczas gdy eksterminacja Żydów była prowadzona bez niczyjego sprzeciwu do samego końca nazistowskiego panowania oraz przynajmniej w Polsce - kontynuowana po upadku niemieckiego nazizmu i ustaniu niemieckiej nazistowskiej okupacji. Tym samym Bauman zbagatelizował antysemityzm. Zlekceważył też równoległość - zorientowanej na eksterminację - ewolucji dwóch typów antysemityzmu: tak zwanego przednowoczesnego (teologicznego) i nowoczesnego (ideologicznego). Co więcej, typy te uznał za istotowo odmienne, jeśli nie przeciwstawne - jakkolwiek absurdalnie by to brzmiało. Zignorował chrześcijańskie pochodzenie antysemityzmu i jego prymarną, pierwotną ramę, jaką stanowi chrześcijaństwo. Oszczędził także autorytet Kościoła katolickiego i innych Kościołów chrześcijańskich ${ }^{39}$. Zignorował wreszcie epistemologiczne, estetyczne i etyczne implikacje odarcia ludzkiego myślenia z krytycznego imperatywu. Imperatywu wyartykułowanego przez... nowoczesność.

\section{Reprezentacja}

Jako postmarksista i poststrukturalista Foucault zalecał, aby nie zwracać uwagi na znaczące, czyli na reprezentację. Zanim ponownie zalegitymizował pytanie o reprezentację, poziom wyżej za sprawą koncepcji dyspozytywu, oznajmiał:

Znaczenia nadawane roślinom przez ludzi były postrzegane jako ich nieodłączne cechy. Nowa „historia naturalna”, która zrodziła się w połowie XVII wieku, oddzielała świat rzeczy od świata znaków. [Innymi słowy, nowa historia naturalna odłączała znaczone od znaczącego - E. J.]. Jak pisze Foucault: „Wszelka mowa naniesiona przez czas na rzeczy zostaje zepchnięta na rubieże" [Michel Foucault, Stowa i rzeczy. Archeologia nauk humanistycznych, przet. Tadeusz Komendant, Gdańsk 2006, s. 123]. To w wyniku owej „puryfikacji”, która odarła przedmioty z ich znaczeń, zrodził się problem reprezentacji. Nagie rzeczy zostały wyłożone na stół lub umieszczone pod mikroskopem: zaczęły być mierzone, obserwowane i systematyzowane na podstawie swych cech zewnętrznych. W tym kontekście zaczęły powstawać i funkcjonować zielniki. „Dokumentami tej nowej historii - pisze Foucault - nie są inne słowa, teksty bądź archiwa, ale określone przestrzenie, gdzie zestawia się rzeczy: zielniki, kolekcje, ogrody" [ibidem, s. 124] (Małczyński, 2018, s. 186).

utrzymane $\mathrm{w}$ „stylu formalnym” - innymi słowy ogrody w stylu francuskim - miały być typowe dla rasy alpejskiej i stanowić zagrożenie dla „rasy nordyckiej”.

39 Niesłusznie. Omawiając zabijanie ludzi z niepełnosprawnościami, Sereny pisze: „Nie ma też najmniejszych wątpliwości, że Hitler był i pozostał do samego końca świadom, jak wielką siłę w Niemczech reprezentuje Kościół. [...] Wybuch wojny stworzył warunki, w których Hitler - jak zapowiedział w 1935 roku - zająt się «rozwiązaniem problemu». Lecz nawet działania wojenne nie wystarczyły, aby odwrócić uwagę Kościołów od tego ciemnego procederu, którego ukrywanie na dłuższą metę i tak nie było możliwe" (Sereny, 2002, ss. 53-54).

Jednocześnie wspomniany Franz Stangl na każdym etapie swej kariery przywiązywał wagę do zaleceń Kościoła katolickiego. Składały się nie między innymi: wezwanie do pomocy nazistom sformułowane przez arcybiskupa Wiednia, kardynała Theodora Innitzera, przedwojenne i wojenne nauczanie papieży oraz - last but not least - dyspensa, którą otrzymał od swojego spowiednika, by zasilić szeregi NSDAP i SS. Po wojnie funkcjonariusze Kościoła katolickiego chronili go oraz pomogli mu zbiec z Europy i ujść przed sprawiedliwością. 
Wchodząc do wnętrza megalitycznego słonecznego zegara Treblinki po raz pierwszy, miałam wrażenie, jakbym wstępowała w szczelinę między rzeczą a jej reprezentacją. Ilekroć tam jestem, wstępuję i kroczę - a raczej czołgam się - pomiędzy.

Reprezentacja to mediatyzacja. Jest cała konstrukcją czy - z Marksowskiej perspektywy rzecz ujmując - produkcją. W ramach i na gruncie reprezentacji nie ma nic neutralnego. Co jest skonstruowane/wyprodukowane, jest do kwestionowania i powinno być kwestionowane. Ponieważ reprezentacja jest grząskim, chybotliwym gruntem, permanentne wątpienie i stawianie w stan podejrzenia czynią ją - jeśli nie bezpieczniejszą i stabilniejszą - przynajmniej bardziej poddaną kontroli. Albo mniej poza kontrolą. I to jest miejsce, w którym usiłowałam pozostawać. Szereg decyzji podjętych w odniesieniu do Zielnika wymaga zatem sproblematyzowania, wyjaśnienia i usprawiedliwienia.

\section{Wybór fotografii}

Dlaczego reprezentacja raczej niż powstrzymanie się od (re)akcji? I dlaczego fotografia? Podróżując z Bełżca do Sobiboru - między stacją początkową Narol a stacją końcową Włodawa - patrzyłam przez okno autobusu na krajobraz daleki i ruchomy. W Treblince był on nieruchomy i bliski. I nie było okna. Mogłam go dotknąć. Miałam go na wyciągnięcie ręki. Pod ręką. Innymi słowy: poruszał się, a potem przestał. Znajdowałam się już nie przed nim czy wobec niego, lecz w nim. We wnętrzu stop klatki. Co więcej, byłam jego częścią. Bez instancji pośredniczących. Sięgnąć po aparat fotograficzny znaczyło uciec się do zapośredniczenia. Powołać instancję pośredniczącą. Instancja, o której mowa, była zrobiona ze szkła. Musiałam przez nie spojrzeć. Operacja przypominała akt przywrócenia okna. Odtworzenia dystansu. Czym też w istocie była. Wszelako chodziło o dystans nie w sensie warstwy izolacyjnej, lecz warstwy problematyzacji.

Tym, co skłoniło mnie do sięgnięcia po aparat fotograficzny, była również konieczność przywrócenia principium individuationis. Odróżnienie przedmiotu od podmiotu jest fundamentalnym wymogiem poznawczym. Samym warunkiem możliwości poznania. Sięgnięcie po aparat jest aktem konstruowania/produkowania przedmiotu i podmiotu. Wraz z ustanowieniem przedmiotu i podmiotu, dyspozytyw optyczny ustanawia odległość między nimi, pozwalając na jej zmniejszanie lub zwiększanie oraz inne poznawcze gesty.

Chodziło o to samo principium individuationis, które tak gwałtownie zaatakował Claude Lanzmann:

Nawet jeśli umiem patrzeć, nawet jeśli jestem obdarzony wyjątkową pamięcią wzrokową, spektakl świata czy świat jako spektakl odsyła zawsze do zubożającego, moim zdaniem, rozdzielenia, do abstrakcyjnej separacji, które uniemożliwiają zdziwienie i entuzjazm, odbierają realność zarazem przedmiotowi i podmiotowi. [...] Była Treblinka i halucynacyjny wstrząs o niekończących się konsekwencjach wywołany spotkaniem z nazwą i miejscem, odkryciem przeklętego imienia na zwykłych drogowskazach i tablicy dworcowej, jakby nic się tam nigdy nie stało. [...] Wreszcie mityczne zwierzę, które pojawiło się w snopie światła moich reflektorów po wyjeździe z patagońskiej wsi El Calafate i dosłownie przeszyło mi serce oczywisto- 
ścią, że jestem w Patagonii, że w tym momencie Patagonia i ja jesteśmy razem prawdziwi. To właśnie jest inkarnacja (Lanzmann, 2010, ss. 501-502).

„Być razem prawdziwi”. „Razem stać się prawdziwi”. Inkarnacja według Lanzmanna zachodzi, kiedy podmiot - w obliczu przedmiotu - może mówić o „naszej wspólnej obecności” (Lanzmann, 2010, s. 174). „Nasza wspólna obecność” to w oryginalnej wersji językowej „notre commune présence” (Lanzmann, 2009, s. 192), którą angielski tłumacz przełożył - ryzykownie, lecz odkrywczo / odkrywczo, lecz ryzykownie - na „our mutual presence” (Lanzmann, 2012, s. 179), czyniąc "naszą wspólną obecność” „naszą wzajemną obecnością".

Wobec zadania, by napisać o Zielniku, zdałam sobie sprawę, że niemal nic z piętnastu lat mojego doświadczenia terenu nie jest w stanie przedostać się przez barierę werbalizacji, chyba że przyjęłabym za swój język wcielenia i objawienia. Ten, w który osuwa się Lanzmann, ilekroć przychodzi mu mówić o Treblince. Z ontologicznych przyczyn nie było to możliwe. Ontologiczne nie znaczy ontyczne. A jednak.

W mojej pracy nad Zielnikiem wcielenie i objawienie przeważały, roszcząc sobie niemal prawo wyłączności. Ilekroć docierało to do mnie, wymuszałam na sobie oddzielenie się od doświadczanego przedmiotu i doświadczającego podmiotu, to znaczy od siebie samej. Świadomość oznacza imperatyw kategoryczny utrzymania rzeczy i jej możliwych (sic!) reprezentacji w polu refleksji. A zatem, nawet jeśli wcielenie i objawienie - w trybie immersji - dominowały, mój tekst odnosi się do „spektaklu świata czy świata jako spektaklu" i relacjonuje zreflektowane, którego dopracowałam się ex post. Ontologiczne parametry, tak się składa, przesądzają, że mam prawo mówić o moim doświadczeniu Treblinki w kategoriach wcielenia tylko w najbardziej dosłownym, pokarmowo-trawiennym sensie tego słowa. Ontologiczne jest polityczne.

$\mathrm{Na}$ potrzeby Zielnika - podobnie jak na potrzeby Miejsca nieparzystego - wybrałam fotografię analogową, którą opisuje formuła Zbigniewa Dłubaka: „Powstaje ona poza nami jako fizyczny kontakt materii z materią" (Dłubak, 1973/2013, s. 156). W swoim rdzeniu analogowa fotografia stanowi połączenie bezpośredniego z pośrednim. Bezpośrednie polega na zjawiskach takich, jak styk, dotyk, odcisk, ślad. Pośrednie polega na zjawisku odbicia (refleksu, refleksji). Zasada bezpośredniości łamanej przez pośredniość odpowiadałaby dwoistemu charakterowi światła. Z tym, co jest stykiem, korespondowałaby jego korpuskularna - materialna - definicja. Z tym, co jest odbiciem (refleksem, refleksją) - definicja światła jako fali.

Pojęcia abstrakcyjne - z pojęciem pojęcia włącznie - wywodzą się z fizycznych, namacalnych zjawisk (Derrida, 1972, 1986). Fotografia jest medium reflektywnym, które w ślad za ustanowieniem podmiotu umożliwia jego re-ustanowienie, czyli ustanowienie ponowne na poziomie, który nazwałabym zreflektowanym, podbudowanym refleksją. Tą samą refleksją, która stanowi cienką warstwę ochronną umożliwiającą rodzajowi ludzkiemu istnienie (przetrwanie?) w środowisku esencji i egzystencji, konieczności i przy- 
padku. Ochronę niecałkowitą i nieostateczną, lecz jednak realną. $\mathrm{Na}$ antypodach znieczulenia czy ucieczki. Jeśli byłam w stanie rozpocząć i prowadzić systematyczną i metodyczną wiwisekcję krajobrazu, to dlatego, że byłam chroniona przez - czy może uzbrojona w - optyczny dyspozytyw aparatu.

Inną zaletą fotograficznego zielnika jest to, że nie wymaga on niszczenia roślin. Jednocześnie, jak każdy środek reprezentacji, fotografia uprzedmiotawia wszystko, cokolwiek, i każdego/każdą, ktokolwiek znajdzie się przed obiektywem. Jednakże, jak każde medium - a nawet bardziej niż media niemechaniczne (za sprawą ostentacyjnej widoczności technicznego dyspozytywu), fotografia jest praktyką i meta-praktyką, mediatyzacją i traktatem o mediatyzacji jednocześnie. Autoanalityczny i autokrytyczny potencjał równoważy jej działanie uprzedmiotawiające.

Dyspozytyw fotograficzny jest obiektem, a raczej zespołem obiektów, lecz nie ma nic wspólnego z obiektywnością. Jego obiektyw powinien nosić nazwę subiektywu. Obiekty zwane maszynami nie mają nic z obiektywności. Są ludzkimi konstrukcjami wynikającymi z ludzkich potrzeb i odpowiadającymi im, obsługującymi ludzkie interesy, sformatowanymi według parametrów ludzkiej percepcji. Percepcji, która także jest medium skonstruowanym i sformatowanym przez psychofizjologię i kulturę. I traktatem o mediatyzacji również. Jeszcze jednym. A nie mówię tu już o własnościach światłoczułego podłoża, którymi miałam okazję się zajmować w pracach przypisywanych do medializmu. W wypadku Herbarium to, co znajduje się przed obiektywem/subiektywem, jest obiektem będącym także kulturową konstrukcją/produkcją. Naturą pochodzenia kulturowego. Cały proces jest zatem rozpięty między wszystkimi tymi zapośredniczeniami a końcowym efektem - czyli fotografiami - między dokumentacją a interpretacją. Przy czym interpretacja nie dotyczy samego tylko rezultatu procesu, lecz pojawia się na samym jego początku i uczestniczy w nim, stając się jego cześcią.

\section{Heimatphotographie - wersja polska}

Nie ma historii fotografii bez Heimatphotographie. Skodyfikowana w Niemczech na początku XX wieku, następnie zaś włączona do państwowego aparatu propagandowego III Rzeszy ${ }^{40}$, zachwyciła polskie środowisko fotografów zawodowych z Janem Bułhakiem na czele w przededniu drugiej wojny światowej. W 1935 roku, niezwłocznie po tym, jak jej niemiecki promotor Paul Lüking opuścił Polskę, Bułhak przetłumaczył i opublikował manifest Heimatphotographie i począł głosić polską „fotografię ojczystą”:

40 Początki Heimatphotographie sięgają Heimatschutzstil - ruchu ochrony tzw. ojczystego krajobrazu, którego podŁoże stanowił neoromantyzm i wczesne europejskie koncepcje ekologiczne połączone z ideą narodową. Jako estetyka - w tym styl obrazowania - nie stronił on od polityki. Wytwarzał mianowicie wizerunek krajobrazu ojczystego za pomocą albumów i innych fotograficznych publikacji opartych na założeniu, że niektóre pejzaże i tematy są specyficznie narodowe. Wczesnym przykładem Heimatschutzstil i Heimatphotographie jest album Die Entstellung unseres Landes (1905) autorstwa Paula Schultzego-Naumburga, architekta, malarza i publicysty, który w 1930 roku wstąpił do NSDAP jako poczesny orędownik architektury nazistowskiej i wiodący krytyk modernizmu (Schultze-Naumburg, 1905; zob. Leśniakowska, 1994). 
Dzisiejsza fotografia ojczysta rodzi się niewątpliwie z prądów zdrowego nacjonalizmu, nurtujących cała Europę, z pragnienia, by wszystko, co własne, narodowe, poznać, zobrazować, pokazać, a następnie - pomnożyć wywyższyć, rozwinąć, wzbogacić. Dzisiejsza fotografia dobrowolnie zaprzęga się w służbę idei mocarstwowej, służbę idei państwa, zespolonego ściśle z narodem i ojczyzną (Bułhak, 1938a, s. 3).

Przyjęta przez ruch definicja narodu była etniczno-religijna, co znaczy: rygorystycznie wykluczająca. Esencję polskości, zagrożoną przez obce elementy oraz nowoczesność, uosabiała katolicka szlachta polska. Ona to zasłużenie władała i wspaniałomyślnie czuwała nad chłopskimi niewolnikami wyznań chrześcijańskich w idyllicznym krajobrazie tak zwanych polskich Kresów złożonych z Litwy, Białorusi i zachodniej, a nierzadko także wschodniej, Ukrainy.

Jak chodzi o Bułhaka:

Kierując miejskim archiwum fotograficznym w Wilnie, fotografował dzielnicę żydowską i żydowskie cmentarze, podobnie jak wiejskie chaty białoruskie i litewskie. Inność stanowiła dla niego jednak problem. Dla Bułhaka Żyd jest raz „długobrodym patriarchą” [Jan Bułhak, Kraj lat dziecinnych, red. Jolanta B. Kucharska (Gdynia: ASP Rymsza, 2003), s. 27], innym razem występuje w takim oto - sporządzonym już w czasie drugiej wojny światowej - opisie: „[M]iasteczko było nędzne, zażydzone i jak wszystkie w naszym kraju doprowadzone przez rządy zaborcze do upadku" [ibid., s. 34]. Na przykładzie rozumowania artysty widać, jak przyciągający mit i odpychający stereotyp stanowią awers i rewers etnonacjonalizmu.

Bułhak sporządzał wizerunki inności po to, by uzasadnić przekonanie o polskiej wyższości. [...] Ta zaś rodzi się z obcowania z ziemią, która pozostaje w najściślejszym sensie polska i szlachecka, co Buthak opisuje w takim na przykład fragmencie, jednym z wielu podobnych:

„Jak na pewnych gatunkach drzew przebywają określone odmiany owadów, jak pewne obszary leśne i gruntowne są terenem bytowania tych, a nie innych typów zwierzęcych, podobnież utworzyły się ściśle zespolone ze sobą kompleksy życia roślinnego i ludzkiego. Jednym z takich przyrodzonych kompleksów jest osobliwy polski organizm psycho-biologiczny, nie mający podobnych sobie w całej Europie - dwór wiejski i osoba zamieszkująca ten dwór szlachcica polskiego na kresach. [...]

[N]ie jako pasożyt przybłęda, wybierający źródło największego zarobku, osiadt on na ziemi i rządzit jej dostatkami. [...] Stał się panem w najlepszym znaczeniu tego pojęcia, panem ziemi rodzącej, obfitej i pięknej. A takie państwo obudza uczucia prawe i dobre [...]. Są to uczucia, które dać może jedynie tradycja i rasa, to wielkie słowo, zbyt często obecnie lekceważone w stosunku do ludzi, aczkolwiek bardzo poważnie traktowane w odniesieniu do zwierząt. [...] Przez kilkaset lat szlachcic sam jeden bronił ojczyzny i odpierał jej wrogów. Nie brali w tym udziału ani chłop, ani mieszczanin, tem mniej niemiecki rzemieślnik-kupiec lub żydowski handlarz-pośrednik" [Jan Bułhak, Wędrówki fotografa w słowie i obrazie, t. Vl: Człowiek twórca krajobrazu (Wilno: Wydawnictwo "Przegląd Fotograficzny", 1936, ss. 5, 12-13] (Janicka \& Żukowski, 2016, ss. 34-36) ${ }^{41}$.

Uruchamiając propagandę Heimatphotogaphie w wersji polskiej, Bułhak nie szczędził krytyki własnemu postępowaniu sprzed objawienia: „[]]ako artysta polski nie miałem racji, bo byłem zbyt wyłączny i zbyt mało znający Sprawę Polską, Ziemię Polską, Przeszłość Polską” (Bułhak, 1938b, s. 202). Przepraszał za to, że myślał o krajobrazie, „zapominając zupełnie o jego - polskiej prawdzie, o tym, że to wszystko jest nasze i polskie"

41 Fragmenty te zostały pominięte $\mathrm{w}$ angielskim tłumaczeniu opublikowanym $\mathrm{w}$ tym samym roku przez tego samego wydawcę. 
(„Sprawozdanie ze Zjazdu Delegatów”, 1937, s. 205). Odtąd w swoich tekstach i fotografiach odmalowywał Polskę jako państwo narodowe, którym Polska wówczas nie była. Aby nim się stać, potrzebowała dopiero Zagłady i dalszych czystek etnicznych. Przedstawiając Polskę jako Polskę dla Polaków, Bułhak podpisywał się pod stanowiskiem, że to, co niepolskie i niekatolickie, stanowi „żerujący na naszym organizmie obcy polip”, „szpecący nasz krajobraz”, jak wyraził się cytowany już szlachcic z okolic Treblinki. „Obcy polip". Innymi słowy, szkodliwy element do usunięcia. Im prędzej, tym lepiej. Wyobrażenie Polski jako Polski dla Polaków działało jak środek produkcji Polski dla Polaków, dopingując, jeśli nie przynaglając, do jej ustanowienia.

Moje zetknięcie z Heimatphotographie - by tak rzec, osobiste - miało miejsce w Kielcach, mieście najsłynniejszego, jakkolwiek dalece nieodosobnionego pogromu po Zagładzie. Gdy przyjechałam tam w październiku 2010 roku, dom przy ulicy Planty 7, w którym zaczęło się zabijanie, mieścił siedzibę kieleckiego oddziału Polskiego Towarzystwa Fotograficznego ${ }^{42}$. Wewnątrz odwiedzający mogli podziwiać dokonania Kieleckiej Szkoły Krajobrazu i otrzymać ulotkę autorstwa jej nestora. Utrzymując, że polski program fotografii patriotycznej de facto wyprzedzał niemiecką Heimatphotographie, Paweł Pierściński oznajmiał:

Kraina polska to szczególny region, odrębny od innych krajów, a przy tym szczodrze wyposażony w tradycje kulturowe i srogo doświadczony przez historię splecioną z losami narodu. Cierpiącej Ojczyźnie szczególny hołd składają artyści, dokumentując urodę swej ziemi. [...] ZIEMIA KIELECKA JEST POMNIKIEM POLSKIEGO KRAJOBRAZU. Ziemia ta jest wartością odrębną wśród krajobrazów świata. [...] Ziemia świętokrzyska przyjmuje swoje dzieci. Mnożą się mogiły powstańców i partyzantów walczących o wyzwolenie narodowe, a cmentarzyska graniczą z bezimiennymi grobami (Pierściński, b. d., s. 1, 5, 9) ${ }^{43}$.

Na wypadek, gdyby ktokolwiek zaczął się zastanawiać nad pochodzeniem owych anonimowych pochówków, autor spieszy z prewencyjnym zapewnieniem: „Mamy prawo do

42 Zlokalizowany wewnątrz sklepik oferował między innymi dobrami Świętokrzyski Magazyn Kulturalno-Artystyczny „Dedal”. Jego wydanie numer 2(209) z 2006 roku nosiło tytuł Polacy i Żydzi razem w kulturze. Na pierwszej stronie okładki widniał uszkodzony zwój Tory ukazany do góry nogami na tle polskiej flagi. Całość została sfotografowana przez Pawła Pierścińskiego. Ostatnią stronę okładki zdobił obraz olejny przedstawiający transakcję pogromu kieleckiego z 1946 roku: Żydów już zabitych oraz jeszcze żywych, lecz bitych na śmierć na ulicy Planty 7, nadzorowanej przez skrzypka na dachu, a raczej na balkonie budynku mieszczącego wówczas maleńką kielecką gminę żydowską. Gdy piszę te słowa, Świętokrzyski Magazyn Kulturalno-Artystyczny „Dedal” leży na moim biurku. Otwiera go wypowiedź Jana Pawła II na temat miłości emanującej z Krzyża w kontekście pogromu kieleckiego. Zamykają natomiast przepisy na specjały kuchni żydowskiej, deklaracja żydowskiej wdzięczności dla tak zwanych polskich Sprawiedliwych wśród Narodów Świata („Nie wiem, czy my, Żydzi, wobec tragedii innego narodu, zdolni bylibyśmy do takiego poświęcenia”) oraz kolekcja zatytułowana Szmoncesy. Aj waj, czyli humor żydowski). Przykład. Chrześcijanin w konfesjonale: „To grzech, że wykantowałem Żydka?”. Odpowiedź księdza: „Synu, to cud!”.Jest też artykuł o Zagładzie, wywiad z ówczesnym dyrektorem Żydowskiego Instytutu Historycznego w Warszawie i - dla symetrii - drugi, z dziennikarzem negującym polskie sprawstwo pogromu kieleckiego. Czytelnikom nie oszczędzono nawet przedwojennej fotografii przedstawiającej żydowską dziewczynkę w polskim stroju ludowym. Zaiste, niczego tam nie zabrakło. Publikacja została sfinansowana przez Ministerstwo Kultury w ramach programu „Promocja czytelnictwa i rozwój sektora książki”. Wskutek zidentyfikowania mnie jako obcej pismo sprzedano mi za podwójną cenę z komentarzem: „Nie sposób was nabrać”.,Wy" w liczbie mnogiej. Miało to niejaki związek z faktem, że zaprotestowałam i zaczęłam się targować, gdy w pierwszej chwili kazano mi zapłacić trzykrotność ceny wyjściowej.

43 Chodzi o Pisanie krajobrazów - maszynopis w archiwum autorki (Pierściński, b.d.). Według zapewnień autora tekst podsumowuje przemyślenia zebrane w dwóch monografiach: Czas krajobrazu. Antologia tekstów z lat 1975-2004 (Pierściński, 2004) i Pagór (Pierściński, 2005). 
dumy z przynależności do naszej Ojczyzny” (Pierściński, b.d., s. 9). Duma. Przynależność. Ojczyzna wolna lub nie, lecz nieodzownie cierpiąca. Mam to wszystko dawno i daleko za sobą. Co innego rzeź, która z tego wszystkiego wynikła. Zostawić ją za sobą, oznaczałoby legitymizację i przedłużenie logiki mordu.

\section{Zielnik jako zasada}

Zielnik jest zbiorem opartym na typologii, a więc klasyfikacji. Ta zaś wymaga selekcji i segregacji (Eco, 2009)44. Dyskryminacji, jednym słowem. Discriminatio znaczy 'różnicuję', 'rozróżniam, 'rozgraniczam'. Zasada dyskryminacji jest własnością ludzkiego myślenia. Warunkiem samej jego możliwości i jednocześnie zabójczym niebezpieczeństwem, śmiertelnym zagrożeniem aż po destrukcję jego biologicznego podłoża: istot ludzkich. Ludzie zamieszkują w tej szczelinie, jak zamieszkują w szczelinie między rzeczą a jej przedstawieniem. Rozróżnianie jest rewersem utożsamiania i na odwrót. Transkategorialne - będące hybrydą tożsamego i różnego - jest kwalifikowane jako monstrualne.

Klasyfikacja polega na przyporządkowaniu do kategorii niemożliwych do wyobrażenia w inny sposób niż przez opozycję do przeciwkategorii. Kategoryzacja stanowi zasadę konstytuującą pojęcia takie jak czystość i nieczystość. Czystość to przynależność. Nieczystość - nieprzynależność. Opozycja czyste/nieczyste

[w]yznacza - lub racjonalizuje - kontury dychotomicznego podziału zbiorowości ludzkich, a niekiedy także stanowi zasadę budowy hierarchii społecznych. [...] Zasięg stosowania tego pojęcia [a raczej: tej opozycji - E. J.] wskazuje, jak bardzo splecione są ze sobą w ludzkiej wyobraźni dwa porządki: biologiczny i społeczny, naturalny i kulturalny (Geremek, 1987, s. 175) ${ }^{45}$.

Mary Douglas odkryła, że w opozycji czyste/nieczyste nie ma nic naturalnego. Brud jest kulturową konstrukcją: „Biologowie myśleli, że brud w postaci wydzielin ciała wywołuje uniwersalne uczucie niesmaku. Powinni pamiętać, że nie ma czegoś takiego jak brud; ani jedna rzecz nie jest brudna w oderwaniu od systemem klasyfikacji, do którego nie pasuje" (Douglas, 2002, s. XVII). Czystość i nieczystość nie są kategoriami opisowymi, lecz normatywnymi. Innymi słowy, brud tkwi w oku patrzącego.

Jak już zostało powiedziane, opozycja czystość/nieczystość produkuje następne opozycje takie jak piękno/brzydota, gust/bezguście, wyższość/niższość, swojskość/obcość, bezpieczeństwo/niebezpieczeństwo. Czystość i nieczystość - ich matryca - są postrzegane jako wzajemnie się wykluczające. Równie często są naturalizowane i esencjalizowane jako... dobro i zło. Innymi słowy, jako kategorie moralne. Tak skonstruowanemu złu przydzielona zostaje rola niebezpieczeństwa, zagrożenia. Po czym podlega ono eksternalizacji. Jako zagrażające oraz obce zostaje następnie zdefiniowane jako to, co musi zostać wyeli-

44 Zwłaszcza rozdziały: 10. Listy mirabiliów, ss. 152-163; 11. Kolekcje i skarbce, ss. 164-199; 12. Wunderkamera, ss. 200-215; 13. Definiowanie przez listę cech i definicja istotowa, ss. 216-229.

45 Geremek odnosi się do prac takich, jak Louis Dumont, Homo Hierarchicus. Essai sur le système des castes (Dumont, 1967) i Louis Dumont, David Francis Pocock, Pure and Impure (Dumont \& Pocock, 1959). 
minowane w imię bezpieczeństwa, swojskości i czystości rozumianej jako cel moralny i estetyczny. Cel usprawiedliwiający wszystko jako - w najgorszym razie - mniejsze zło.

Bezpieczeństwo, swojskość, czystość, niewinność, piękno, zdrowie. Przechodzące jedno w drugie. Częstokroć wymienne. Wyobrażane jako naturalne i moralne jednocześnie. Tłumaczone na koncept idyllicznego krajobrazu. Podczas gdy wyroby mleczne z Kosowa Lackiego reklamują się swym pochodzeniem z Nadbużańskiego Parku Krajobrazowego, herbatki ziołowe Zielnik Polski kuszą potencjalnego nabywcę: „Zioła zawarte w Zielniku Polskim pozyskiwane są poprzez firmowe punkty skupu, mieszczące się w najczystszych, wschodnich rejonach Polski”. Za zgodność z prawdą: Herbapol-Lublin S.A., ulica Diamentowa 25, 20-471 Lublin, Polska. Wszystko to jest opowieścią o klasyfikacji z czystością kategorialną jako jej źródłową ambicją.

Klasyfikacja, typologia, przynależność do kategorii. Oto co leży u podstaw idei kolekcji (zob. Elsner \& Cardinal, 1994; Pomian, 1987, 2012). Zielniki są jednym z jej przejawów. Z tych samych przesłanek wynika również miejsce zwane Treblinką. Nie przez przypadek Linneusz, poza tym że ustanowił nowy system taksonomii botanicznej, był jednym z pierwszych, którzy zaczęli konstruować „ludzkie rasy” na podstawie kolorów skóry. Trudno było opowiedzieć się za zasadą bardziej obciążoną niż zasada zielnika. Po dokonaniu wyboru coś zatem musiało zostać przedsięwzięte. Musiały zostać wdrożone środki zaradcze. Jednocześnie z działaniem musiałam podjąć przeciwdziałanie.

\section{W stronę hybrydyzacji}

Purity and danger. Czystość i zagrożenie. Czystość jako zagrożenie. Czystość to zagrożenie. Starając się pozostać tego świadoma, starałam się też podążać za wszystkim, co mogło prowadzić ku hybrydyzacji typologii, rozszczelnieniu reguł klasyfikacyjnych. Moim celem było wprowadzić nieco powietrza do szczelnego systemu, szczelnego ładu, który - jako zasada - doprowadził do szczelnych pojemników, których fundamenty są wyczuwalne dla bosej nogi pod cienką warstwą trawy na jasnej polanie Treblinki. Pierwsza z moich decyzji odnosiła się do zasad organizacji materiału. Postanowiłam odbiec od porządku typowego zielnika (synchronicznej prezentacji według stopni taksonomicznych: typu, klasy, rzędu, rodziny, rodzaju, gatunku) na rzecz reżimu innego rodzaju, łączącego linearne i cyrkularne, diachroniczne z synchronicznym. Sukcesja obrazów następuje więc zgodnie z sukcesją miesięcy i dni. Podczas gdy lata - jakkolwiek odnotowane - nie mają wpływu na jej porządek.

Na myśli, czy przed oczami, nie miałam konkretnego modelowego zielnika - fotograficznego lub nie. Znałam rysunki i malarstwo Marii Sybilli Merian - przełożone na czarno-białe oraz kolorowe miedzioryty, poczynając od jej trzytomowego Blumenbuch (1675-1680) przez dwa tomy Der Raupen wunderbare Verwandelung und sonderbare Blumen-Nahrung 
(1679-1683) aż po Metamorphosis insectorum surinamensium (1705) (Zemon Davis, 2012). Studiowałam Zielnik Stanisława Wyspiańskiego (1896) składający się z rysunków, które artysta sporządzał na łąkach w pobliżu Krakowa, a także w samym centrum miasta: Ogrodzie Botanicznym, ogrodach franciszkanów i dominikanów, na Plantach, na skałach Smoczej Jamy (Gołubiew i in., 2007). Egzaminowałam Zielnik Elizy Orzeszkowej (1887-1898), zawierający zasuszone rośliny z rejonu Grodna (zob. Kielak, 2004) i skomentowany przez autorkę $\mathrm{w}$ duchu klasistowskiego oraz kolonialnego nacjonalizmu bliskiego poetyce Blut und Boden. W łódzkiej szkole filmowej słuchałam wykładów Lecha Lechowicza na temat dziewiętnastowiecznej brytyjskiej fotografii przyrodniczej, w tym fotogramów natury. Następny w kolejności byt nurt Neue Sachlichkeit z monumentalną fotograficzną kolekcją roślin Karla Blößfeldta (Zob. Blößfeldt, 1929). Wreszcie w moim horyzoncie pojawił się Notes botaniczny Romana Kobendzy (1930-1952) prowadzony na szklanych kliszach za pomocą kamery wielkoformatowej w kolejnych oddziałach Ogrodu Botanicznego Uniwersytetu Warszawskiego (Kobendza \& Sokołowska, 2012).

Był też Zielnik Róży Luksemburg (1913-1918) z naturalnymi roślinami (Luksemburg, 2009) oraz dwie prace Aliny Szapocznikow znacznie mu bliższe, niż ktokolwiek mógł przypuszczać: Zielnik - Autoportret (1971) i seria Zielnik I-XVI (1972) (Gołubiew \& Rottenberg, 1998, ss. 106-112). Pierwsza będąca poliestrowym odlewem dorosłego kobiecego ciała trawionego rakiem, które było jej własnym ciałem. Druga złożona z poliestrowych odlewów dorosłego ciała męskiego należącego do jej adoptowanego syna. W obu wypadkach odlewy wyjściowo trójwymiarowe zostały sprasowane, zredukowane do dwóch wymiarów i nałożone na polichromowane drewno. Szpocznikow przetrwała getto w Pabianicach, getto łódzkie, obóz koncentracyjny Bergen-Belsen (dokąd została wywieziona via Auschwitz) oraz Theresienstadt. Jako pomocnica własnej matki, lekarki pediatry, spędziła ten czas wśród ciał umierających i martwych. W Zielniku mówiła o ciele na podstawie własnego doświadczenia. Andrzej Wajda, często głuchy i ślepy na rzeczywistość, zuniwersalizował Zielnik. Zarazem jednak określił go jako „groźny i zdumiewający ślad" (Wajda, 1996), którym Zielnik Szapocznikow istotnie jest.

\section{Matronki}

Zachętą do rozszczelnienia systemu systematyzacji (sic!) był mi przykład dwóch kobiet. Marii Sybilli Merian i Róży Luksemburg. Merian przedstawiała rośliny wraz z owadami w różnych stadiach ich rozwoju. Była naturalistką i mimetystką urodzoną i wychowaną w tradycji martwej natury:

Jednak w odwzorowywaniu owadów z natury Maria Sybilla Merian miała inny cel. Ćmy i gąsienice z jej Raupen nie były tylko dodatkiem ożywiającym (lebendig) obrazy kwiatów, jak w przypadku bukietów i wiązanek malowanych przez jej ojczyma Marrela czy jego studenta Abrahama Mignona. [...] Czas w jej rysunkach płynąt nie po to, żeby ukazywać ogólną przemijalność rzeczy czy cykl roczny najcenniejszych kwiatów, lecz aby oddać konkretny i ciągły proces zmian. Jej owady nie służyły metaforycznym przesłaniom, jak u wielu malarzy martwej natury, a w szczególności u nauczyciela jej ojczyma w Utrechcie, Jana Davidsza de Heema 


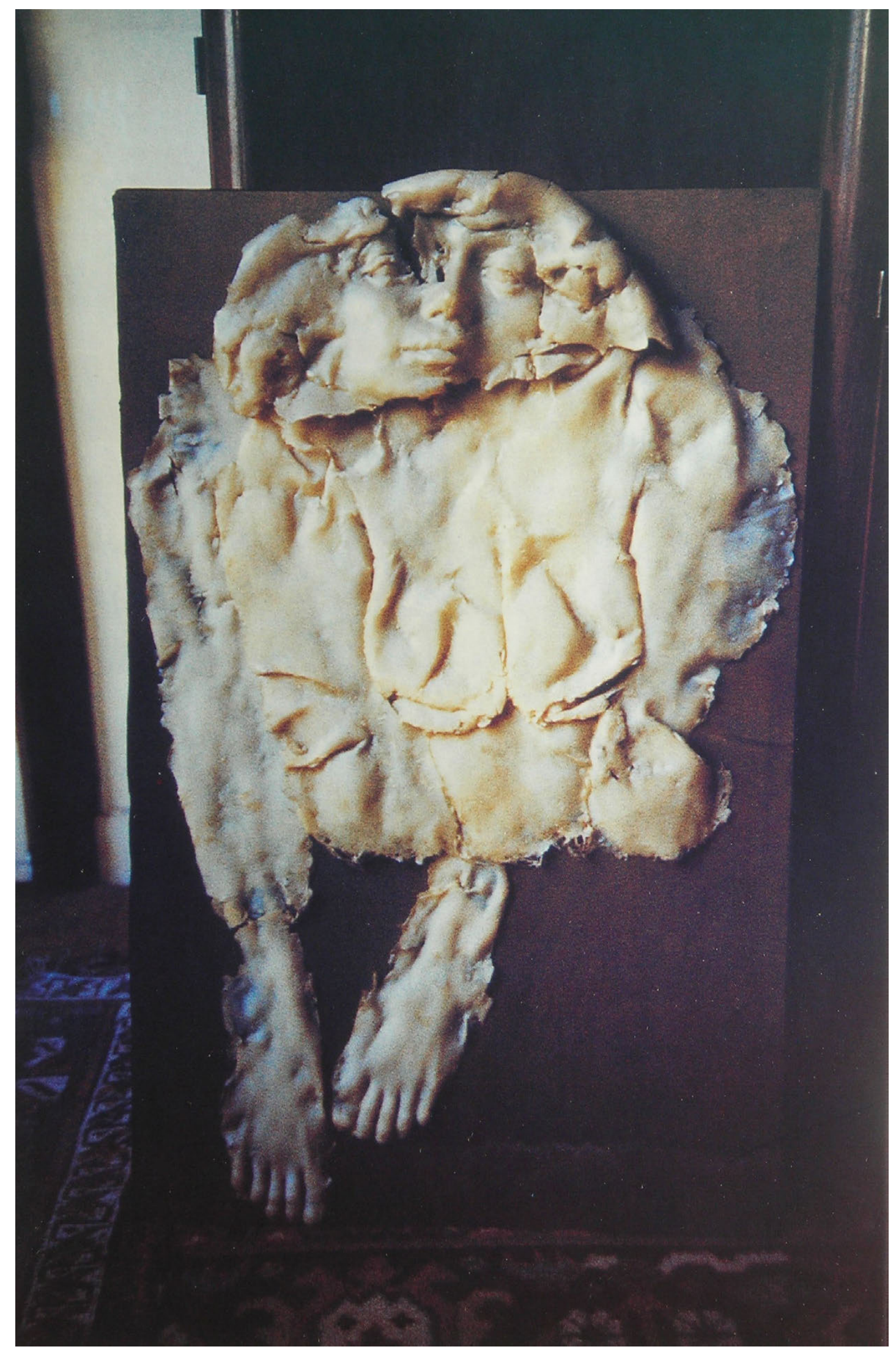

Alina Szapocznikow, Zielnik - Autoportret (1971). Poliester, drewno polichromowane, 81 x 52 × 5 cm. Własność Ceres Franco (fot. Jolanta Gola) (๔ by Jolanta Gola, dzięki uprzejmości Autorki zdjęcia) 


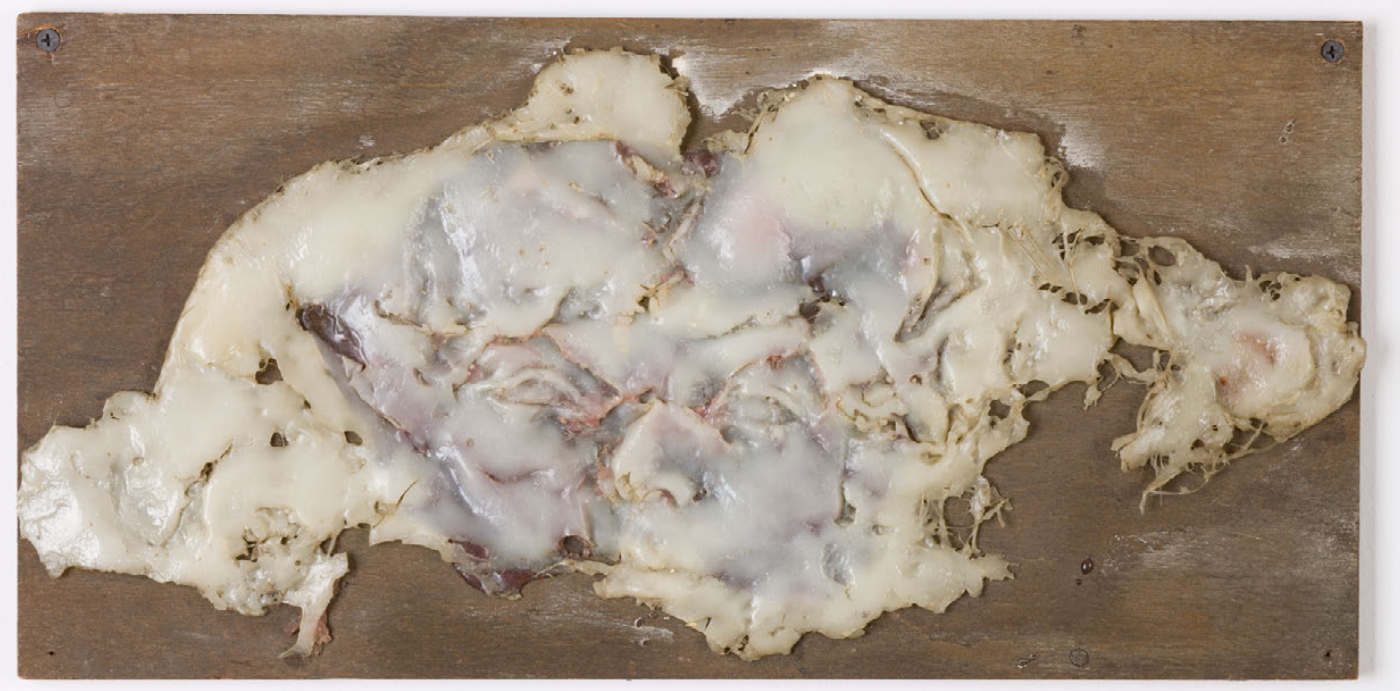

Alina Szapocznikow, Zielnik XI (1972). Poliester, drewno polichromowane, 24 × 38 × 2 cm, nr inw. MNK II-rz-1666. Własność Galerie Loevenbruck (fot. Muzeum Narodowe w Krakowie) (๔ by Muzeum Narodowe w Krakowie, dzięki uprzejmości Placówki). Specjalne podziękowania zechcą przyjąć Hervé Loevenbruck i Alexandra Schillinger

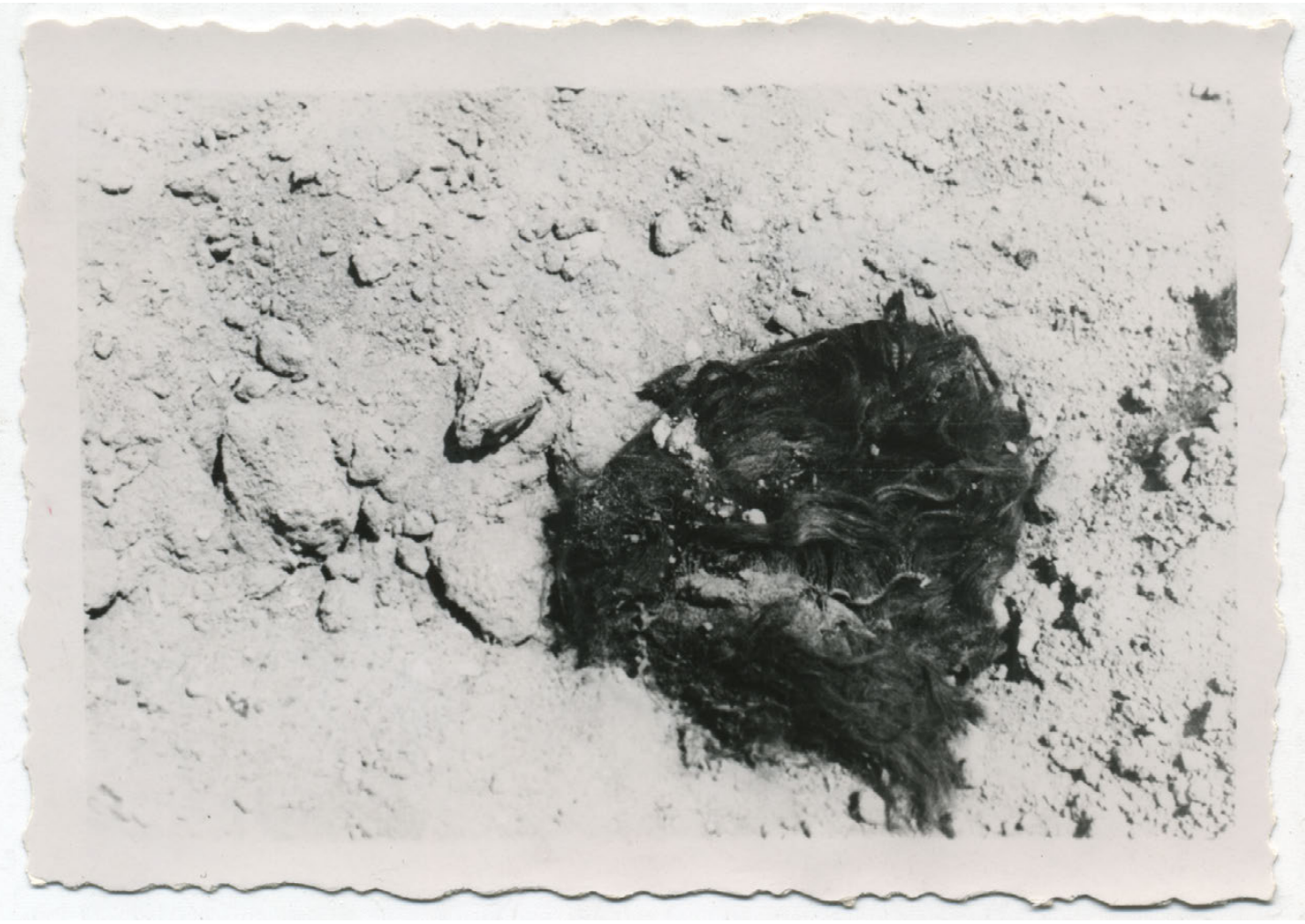

Podpis na rewersie (ołówkiem): „Włosy ze skórą ścięte. 18 czerwca 1947”. Teren byłego obozu zagłady Treblinka II (fotograf nieznany; ze zbiorów Žydowskiego Instytutu Historycznego im. Emanuela Ringelbluma w Warszawie) 
(motyl jako symbol wskrzeszonej duszy, mucha jako symbol grzeszności etc.) (Zemon Davis, 2012, ss. 156-157).

Prace Merian są uważane za część rękodzielniczej tradycji kobiet, które zajmowały się nauką, nie posiadając akademickiego wykształcenia. Jako botaniczka i entomolożka Merian była orędowniczką zmiany w obrębie dominującego arystotelesowskiego systemu klasyfikacji. Poszukiwała nowych podstawowych kryteriów klasyfikacyjnych. W jej pracach

[u]kład kolejnych obrazków raczej nie pasował do żadnego z ówcześnie stosowanych kryteriów klasyfikacyjnych - botanicznych czy entomologicznych. Rośliny pospolite nie poprzedzały koniczyn, za którymi, jak w tradycyjnych układach herbalistycznych, następowały krzewy i drzewa; roślin drzewiastych nie oddzielono od trawiastych, jak w nowszych koncepcjach; nie grupowano razem podobnych owoców i roślin. [...] Także gatunki owadów, które umieściła poza „rzędem lepidoptera” (nazwa nadana później przez Linneusza), nie znalazły się wszystkie w jednej grupie: metamorfozy pszczót i os, chruścików, much i wciornastek często przedstawiała na tych samych rysunkach, co przemiany ciem i motyli, ponieważ obserwowała ich gąsienice czy czerwy żerujące na tych samych roślinach.

Cel Merian po prostu wykraczał poza sztywne ramy jakiejkolwiek klasyfikacji. Interesowała ją seria wydarzeń - „W tomie tym znajdziecie ponad sto transformacji [Verwandlungen]" napisała w 1683 r. - i by przedstawić je należycie, należało przekroczyć granice między rzędami i umieścić królestwo roślin i zwierząt na tym samym rysunku (Zemon Davis, 2012, ss. $160-161)^{46}$.

Natalie Zemon Davis podkreśla transgresyjny pierwiastek indywidualnych narracji Merian i nazywa ją „artystką-naukowcem” [an artist-scientist], „artystką-naturalistką, która wcześniej skutecznie broniła się przed wszelkimi systemami klasyfikacji”, ,kobietą, której nie można było przyszpilić” (Zemon Davis, 2012, ss. 175, 171, 173) ${ }^{47}$. Ponadto „Merian

46 „Jednakże brak logiki klasyfikacyjnej nie oznaczał, że układ jej pracy był «chaotyczny»” (Zemon Davis, 2012, s. 161). Pracując nad swoim opus magnum, ,[z]robiła przerwę w przygotowywaniu obrazów dla rytowników [...], żeby za opłatą zrobić rysunki do książki innego autora" (Zemon Davis, 2012, s. 186). Chodziło o dzieło Georga Everarda Rumpfa poświęcone skorupiakom, muszlom i minerałom z wyspy Amboina. „Wykonała je w objaśniającym stylu Rumpfa, a nie we własnym: rzędy muszli, krabów i kryształów z literami i numerami odnoszącymi się do tekstu. D’Amboinische Rariteikamer została opublikowana w roku 1705, tym samym co jej własna księga, i pokazuje, do jakiego stopnia jej sposób przedstawiania natury był jej wyborem, a nie kwestią umiejętności czy panującego zwyczaju. [...] Pogłębiając rozdźwięk między własnym systemem a stosowanymi ówcześnie klasyfikacjami, na sześciu rysunkach umieściła dodatkowo jaszczurki, węże, żaby i ropuchy” (Zemon Davis, 2012, ss. 186, 187).

47 „Mary Louise Pratt opisała pracę europejskich naturalistów, którzy w czasach Linneusza i później wyruszali za granicę, kształtując w ten sposób «nowy rodzaj [...] świadomości planetarnej wśród Europejczyków»: «Formy życia na naszej planecie miały być, jedna za drugą, wyplątane z zawikłanych sieci swego środowiska i ponownie wplecione w utworzone przez europejski umysł systemy globalnej jedności i porządku. Oko - oświecone, męskie, europejskie - które ustanowiło system, mogło oswoić ('udomowić) nowe miejsca/widoki zaraz po zetknięciu się z nimi, włączając do języka systemu». Pratt sugeruje, że ta wizja świata jest jednocześnie «niewinna i władcza», wspomagająca europejską ekspansję gospodarczą, ale ogranicza się do nazywania i klasyfikowania [Mary Louise Pratt, Imperial Eyes: travel writing and transculturation (London and New York, Routledge, 1992, ss. 31, 33-34)]. Metamorfoza Merian z pewnością stanowi część wczesnych etapów tego projektu europejskiego patrzenia i opisywania. Ale jej ekologiczne spojrzenie i dłoń pozostawiają wiele swobody owadom i roślinom surinamskim, tak żeby mogły rozwijać się w ramach ich własnego otoczenia i powiązań" (Zemon Davis, 2012, s. 188). Merian zachowała lokalną nomenklaturę. W swoich opisach pełnych realiów holenderskiego systemu niewolniczego na Surinamie często odnosi się do afrykańskich oraz indiańskich niewolników, których tymczasowo posiadała podczas dwuletniego pobytu w tym kraju. Jej komentarz do Flos pavonis, „pawiego kwiatu", mówi o wyzysku, nieludzkim traktowaniu niewolników - mężczyzn i kobiet - o samobójstwie jako sposobie unikania i aborcji jako środku niereprodukowania niewolniczego statusu. Merian napisała: ,Stucham kobiet afrykańskich", co - według Zemon Davis - naruszało ustalony porządek kolonialnego spotkania (Zemon Davis, 2012, ss. 194 i następne). 
najwyraźniej traktowała swe książki jako przedłużenie pracy fizycznej i obserwacji” (Zemon Davis, 2012, s. 212).

W spuściźnie Róży Luksemburg natomiast znajduje się osiemnaście zeszytów, z których siedemnaście zawiera 370 starannie zebranych, zasuszonych i zidentyfikowanych roślin. Składają się one na zielnik, nad którym pracowała od maja 1913 roku. Więziona w Berlinie, Wronkach, Breslau oraz na wolności. Na okładce przedostatniego z zeszytów odnotowała: „Zeszyt XVII / Breslau Strafgefängnis / 13 października 1918 -”. Zamordowana zaś została 15 stycznia 1919 roku. Ostatni zeszyt jest nie mniej znaczący. Luksemburg zatytułowała go Geologische und Botanische Notizen (Breslau):

Zwiera on wyimek Das natürliche System z opublikowanego po raz pierwszy w 1876 r. w Kilonii, później w 1880 r. w Berlinie podręcznika A. W. Eichlera Sylabuss der Vorlesungen über spezielle und medizinisch-pharmazeutische Botanik. Rosa Luksemburg korzystała z wydania berlińkiego z 1880 r. [...]

O swoich studiach geologicznych pisała 24 listopada 1917 r. z więzienia w Breslau w liście do Luise Kautsky (żony Karla Kautsky’ego): „Geologia całkowicie mnie pochłonęła, niesamowicie mnie interesuje i uszczęśliwia. Boję się, gdy pomyślę, jakie krótkie to moje życie, a ile jeszcze można byłoby się nauczyć" (Luksemburg, 2009, s. 370) ${ }^{48}$.

Nie jestem pewna, czy moje studia przynależą do dziedziny geologii szczęściodajnej. Lecz także się boję.

Co do Luise Kautsky, to w czasie wolnym (od bycia żoną Karla Kautsky’ego) była ona socjaldemokratyczną polityczką i radną Berlina z ramienia Niezależnej Socjaldemokratycznej Partii Niemiec (Unabhängige Sozialdemokratische Partei Deutschlands). Deportowana jako Żydówka podczas drugiej wojny światowej, zginęła w Auschwitz II Birkenau w 1944 roku. A co do Zielnika Róży Luksemburg, to stał się on obiektem zainteresowania medycyny sądowej w poszukiwaniu jej martwego ciała. Jako potencjalne źródło DNA. Zdumiewający związek ze sposobem, w jaki myślała o zielniku Alina Szapocznikow: jako ściśle związanym, jeśli nie wręcz tożsamym ze szczątkami cielesnymi.

Róża Luksemburg jest matronką mojej pracy, także jako mistrzyni myślenia krytycznego. Nie znaczy to, że nie podzielała niektórych przekonań czy nawyków myślowych swojego czasu, zwłaszcza w odniesieniu do własnego polskiego habitusu - w przeciwieństwie do tego, co się w Polsce na ten temat sądzi. Są one widoczne chociażby w jej korespondencji z Leo Jogichesem. Jednakże w całokształcie jej opus vitae to analiza i krytyka wzięły górę. Przede wszystkim i nade wszystko była bowiem świadoma zagrożenia, jakie dla emancypacji gatunku ludzkiego i jego istnienia oraz wspótistnienia z ekosystemem stanowi kapitalizm sprzężony z polityką tożsamości. Ta sama Róża Luksemburg, której uczono mnie nienawidzić jako autorki słów:

Moi rodacy zarzucają mi, że nie chcę niepodległości mojej ojczyzny! A ja przecież nie chcę zabijania. Nie chcę krwi. [...] A gdyby tak, na przykład, wreszcie po wielkim rozlewie krwi powstała wolna Polska, to byłaby z pewnością kapitalistyczno-klerykalna. I jaka byłaby z tego

48 Komentarz edytorski bez tytułu. 


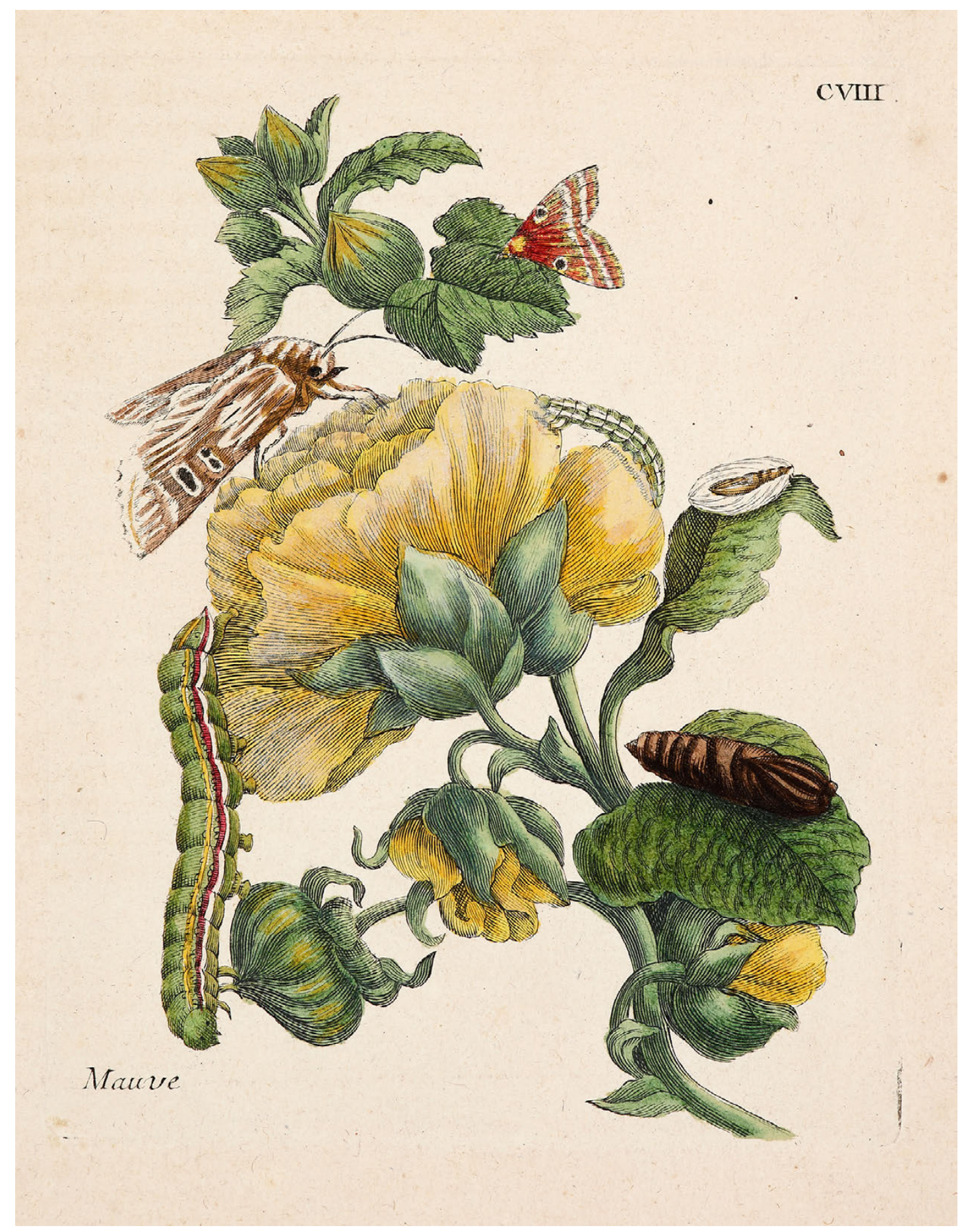

Maria Sibylla Merian, Ślaz i stadia rozwoju powszelatka malwowca - miedzioryt kolorowany akwarelą i gwaszem z kolekcji Kunstkabinett Strehler (dzięki uprzejmości Anny Król z Muzeum Sztuki i Techniki Japońskiej Manggha) 


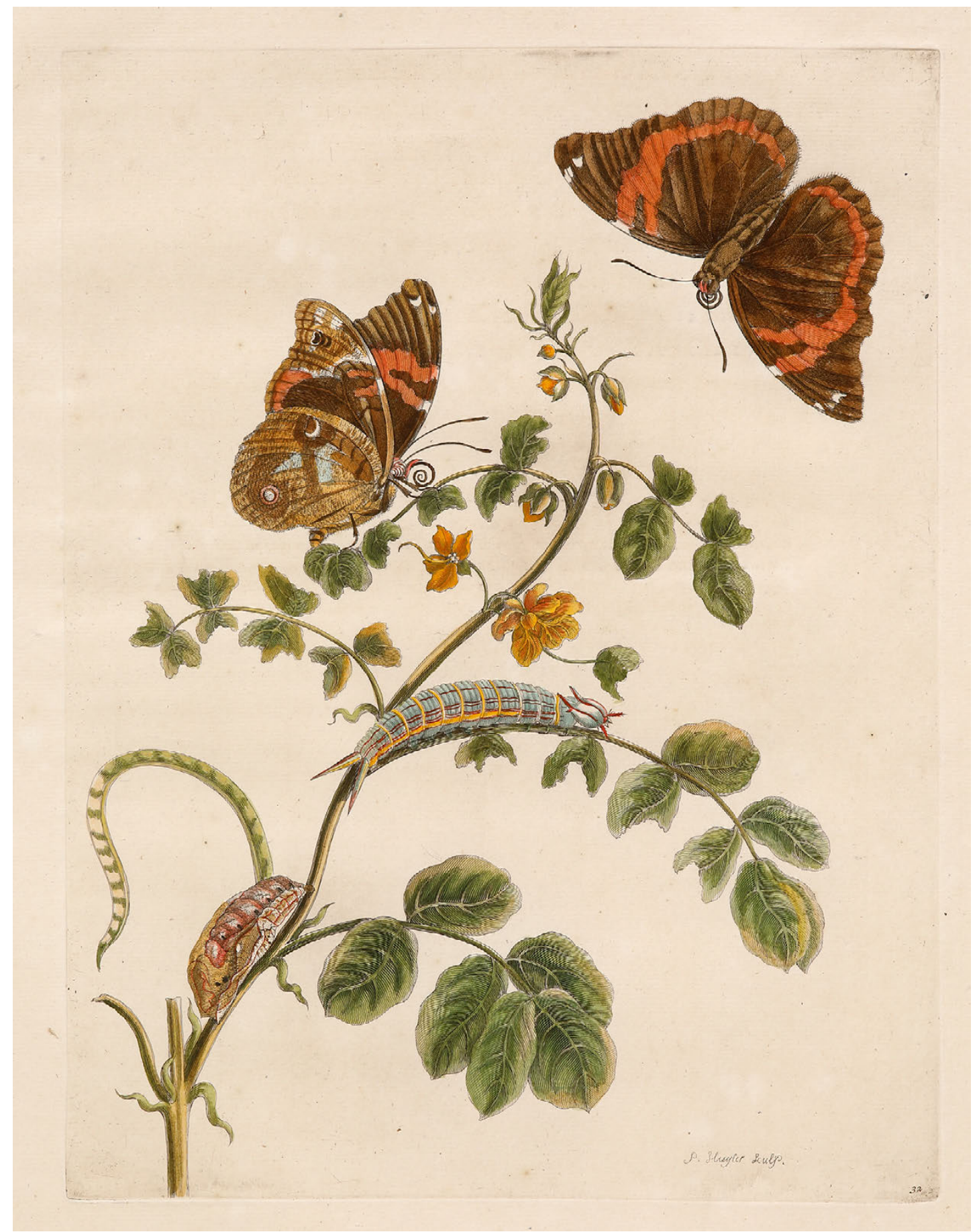

Maria Sibylla Merian, Straczyniec i stadia rozwoju motyla z rodziny Opsiphanes - miedzioryt kolorowany akwarelą i gwaszem z kolekcji Kunstkabinett Strehler (dzięki uprzejmości Anny Król z Muzeum Sztuki i Techniki Japońskiej Manggha) 


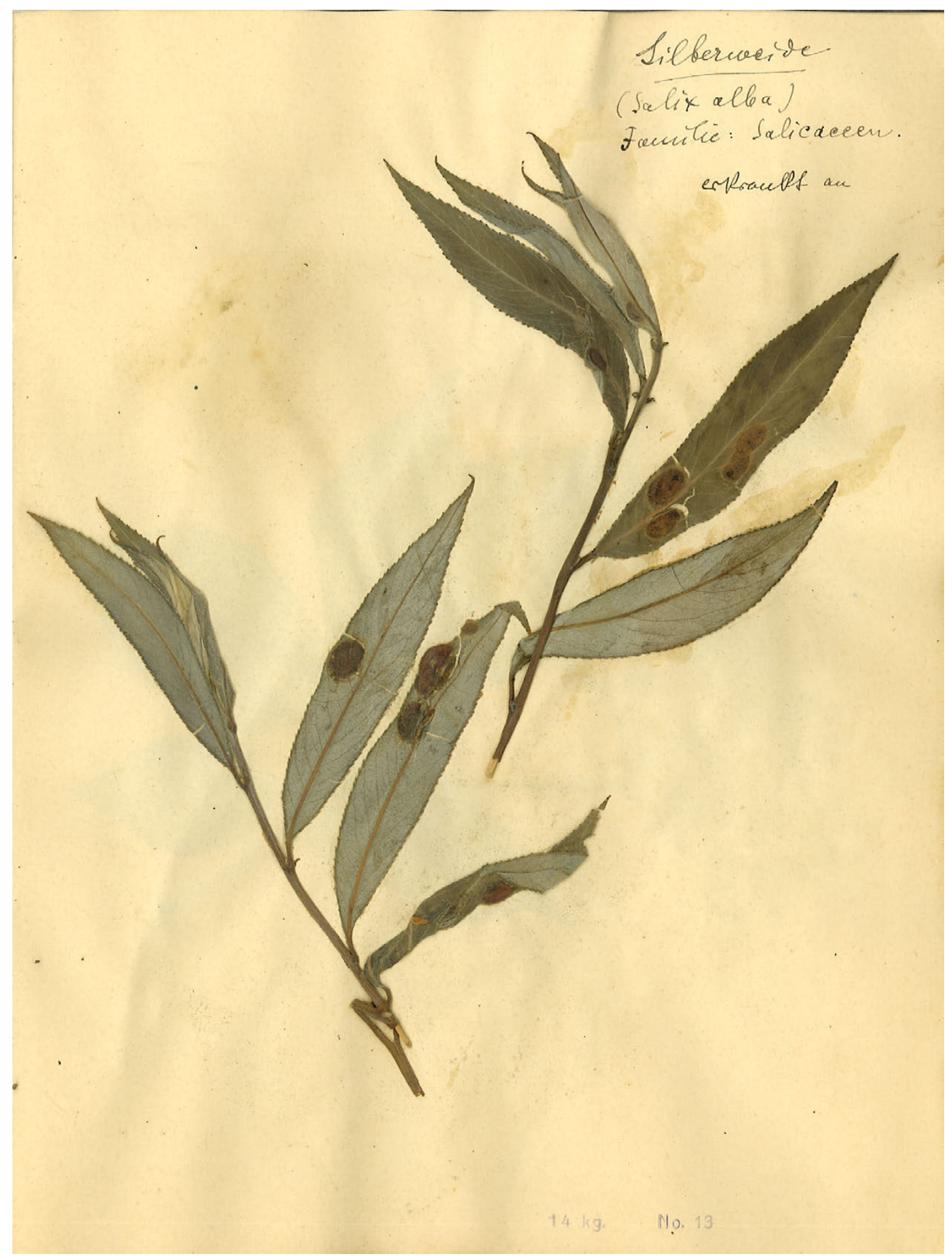

Salix alba, czyli wierzba biała, z zeszytu czwartego (1-8 czerwca 1913) Zielnika (1913-1919) Róży Luksemburg (akta Róży Luksemburg w zbiorach Archiwum Akt Nowych, pierwotnie w Archiwum KC PZPR) 


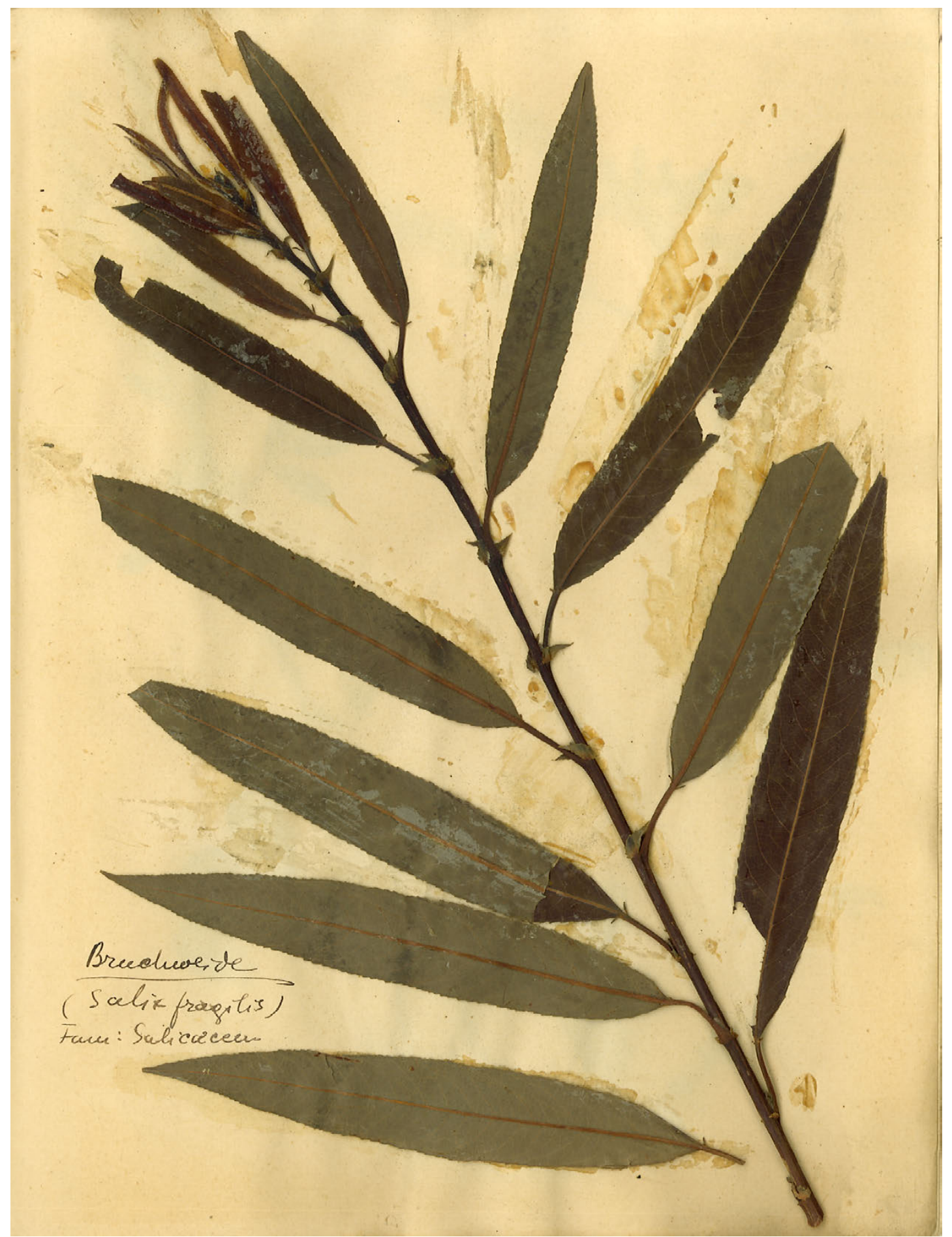

Salix fragilis, czyli wierzba krucha, z zeszytu piątego (10-20 czerwca 1913) Zielnika (1913-1919) Róży

Luksemburg (akta Róży Luksemburg w zbiorach Archiwum Akt Nowych, pierwotnie w Archiwum KC PZPR) 


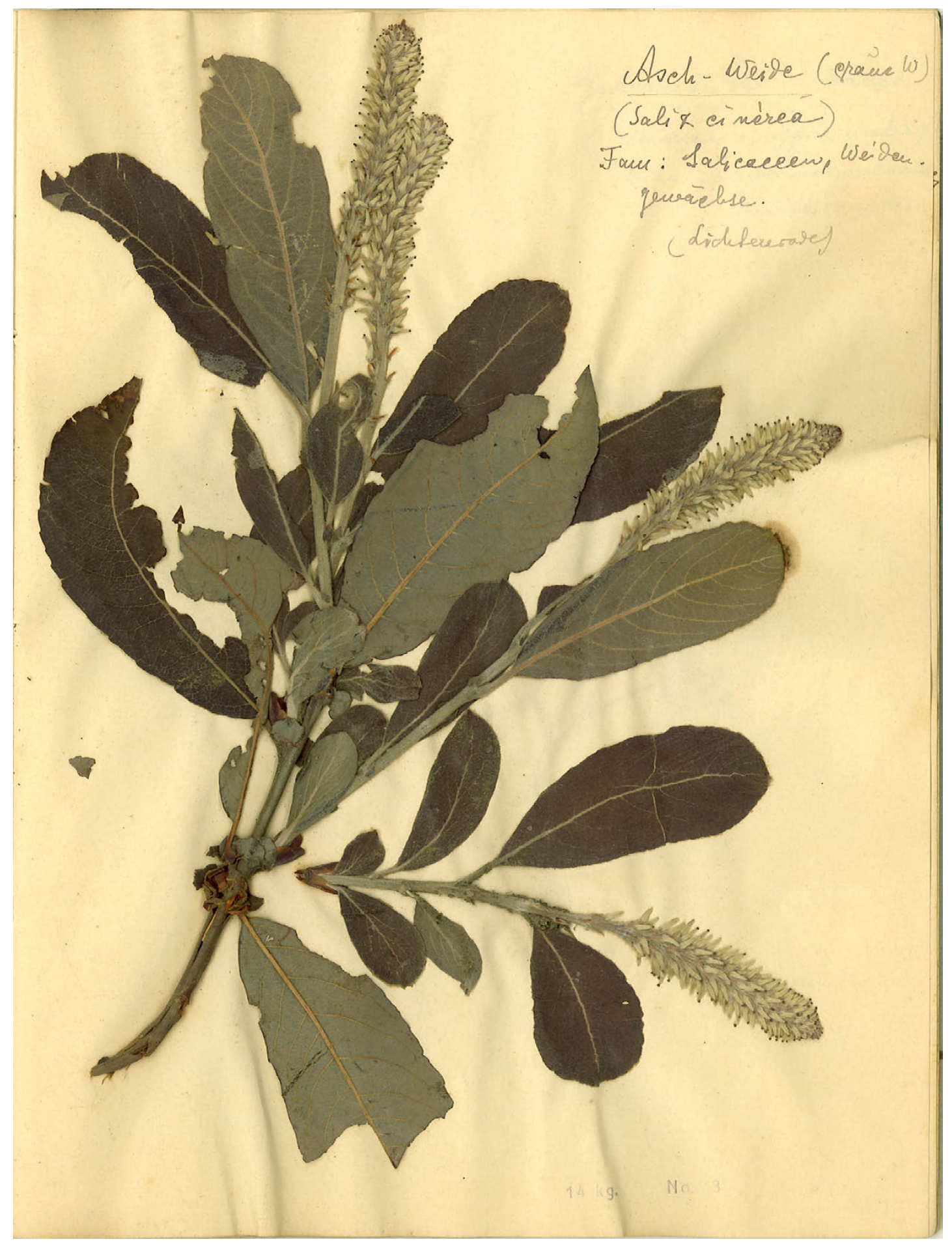

Salix cinerea, czyli wierzba szara, z zeszytu dziewiątego (9-31 lipca 1913) Zielnika (1913-1919) Róży

Luksemburg (akta Róży Luksemburg w zbiorach Archiwum Akt Nowych, pierwotnie w Archiwum KC PZPR) 


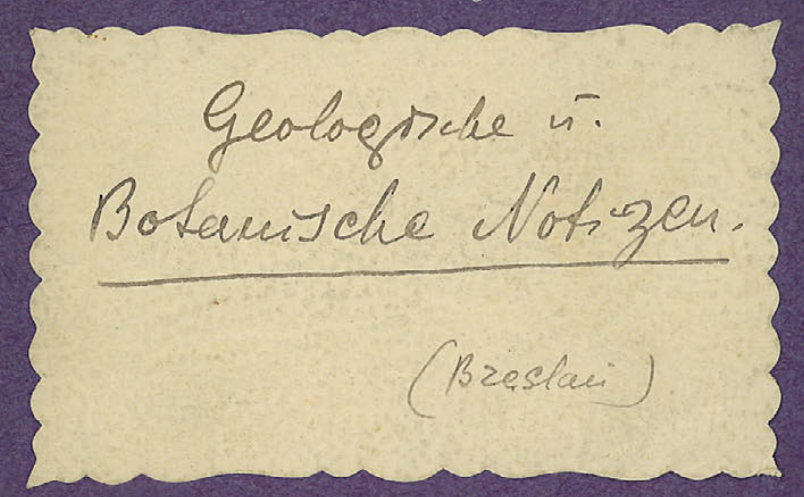

Notatki geologiczne i botaniczne (Breslau) - okładka zeszytu osiemnastego Zielnika (1913-1919) Róży Luksemburg (akta Róży Luksemburg w zbiorach Archiwum Akt Nowych, pierwotnie w Archiwum KC PZPR) 
korzyść dla uciemiężonych? Gdyby w takiej Polsce nawet gwarantowano ludowi jaką taką egzystencję, to wskutek pobożności i konserwatywnego usposobienia naszego ludu Polska taka stałaby się niedostępną twierdzą dla idei socjalistycznej (zob. Luxemburg, 1905/b.d.).

Róża Luksemburg została skrócona o głowę przez innych - niemieckich - patriotów, gdy tylko pierwsza wojna światowa dobiegła końca. Ledwie zdążyła ujrzeć zaranie wolnej Polski skąpanej we krwi Żydów i innych mniejszości. Wszelako wiedziała. Jej słowa sprawdziły się w odniesieniu do kapitalistycznej i klerykalnej Polski międzywojennej. Prawdziwe okazały się także w odniesieniu do Polski powojennej - formalnie socjalistycznej. I prawdziwe pozostają w odniesieniu do Polski po 1989 roku, kapitalistycznej i klerykalnej na powrót. Wzory kultury działają z siłą przymusu. Działają jak prawa fizyki dopóty, dopóki nie zostaną rozpoznane, sproblematyzowane i nie zaczną być zwalczane. Luksemburg rozpoznała wzór. Sto lat później kraj jej urodzenia pamięta jej to. I odpłaca nienawiścią.

\section{Transgresja}

To Merian i Luksemburg dodały mi odwagi, by rozleglej rozejrzeć się po otoczeniu i złamać reguły. Dlatego też niektóre rośliny pojawiają się w Zielniku dwukrotnie. W stadium kwiatu i w stadium owocu. Jednocześnie dla niektórych gatunków niektóre stadia mogą nie być reprezentowane. Jest to przypadek kwitnącego maku. Najbardziej udało mi się do niego zbliżyć w dniu, w którym ujrzałam makowy płatek płonący żywcem dosłownie zamieniający się $w$ popiół - na rozpalonym betonie Treblinki. Nie miałam refleksu, by udokumentować to, co widziałam. Patrzyłam na spektakl obracania się w niebyt, oniemiała i obezwładniona.

Złamanie reguł oznaczało także rozszerzenie wyjściowego projektu herbarium o bestiarium, ossuarium oraz lapidarium w ślad za naturalnymi/kulturalnymi realiami miejsca. W krok za rzeczywistością, która powinna być widziana, badana, opisywana i odzwierciedlana przez pryzmat nie tylko botaniki, lecz także zoologii. Wszak czyż na terenie obozu nie wzniesiono ZOO na obraz i podobieństwo Arki Noego ${ }^{49}$ ? Czyż miejsce to nie jest i dzisiaj pełne ptaków, do których obozowe SS miało szczególny sentyment? W albumie fotograficznym, który ludzkość dziedziczy po Kurcie Franzu - zastępcy, a później następcy Franza Stangla - widnieje też lisi pyszczek. Podobny do tego, który powitał Teresę Alter na progu lasu (T. C. Masson, 2016). Co zaś tyczy się saren z ZOO, zdarza mi się widywać cienie i słyszeć tętent kopyt ich następczyń, gdy pracuję. Ziemia drży przez chwilę, kiedy przebiegają. Napotkałam też ich czaszki w południowej części byłego Totenlager. W liczbie dwóch. Jedną dorosłą i jedną dziecięcą. Stąd ossuarium.

Ossuarium obejmuje wyraźne fragmenty szkieletów zwierzęcych i drzazgi kostne ludzkiego pochodzenia. Jeden ząb ludzki także. Jakkolwiek - w optyce „panów sytuacji” - żywa istota, do której należał ząb, nie była postrzegana i nie została zamordowana

49 Zob. malarskie reprezentacje Arki Noego w Szaleństwie katalogowania Umberto Eco (Eco, 2009, ss. 152-163). 
jako istota ludzka. Uniwersalistyczne kategorie były jej i jej podobnym dostępne jedynie warunkowo. 0 ile w ogóle. Czy zatem powinnam powiedzieć: drzazgi kostne żydowskiego pochodzenia i żydowski ząb? Czy reprodukuję gest wykluczenia, mówiąc w ten sposób? Zwłaszcza, że zakwalifikowanie ich jako ludzkich - „Ludzie ludziom zgotowali ten los"50 - zamazałoby, jeśli nie wymazało, realia zbrodni, służąc interesom współodpowiedzialnych za nią społeczeństw i kultur. Jakkolwiek by było, niepasujące nigdzie kości w formie drzazg tkwią w rdzeniu ossuarium. Niektóre z nich białe, gdyż nietknięte ogniem. Niektóre z nich czarne, osmalone. Ossuarium dokumentuje pomieszanie ludzkiego ze zwierzęcym. Jednakże porównując stan szczątków, można zobaczyć różnicę w potraktowaniu, jakiemu zostały poddane. Pośmiertna obojętność względem pozostaŁości zwierzęcych staje tu naprzeciw wojennej nazistowskiej i powojennej polskiej agresji wobec szczątków ludzkich, zdefiniowanych jako szczątki żydowskie.

Jeden z ocalałych z Treblinki, Jechiel Rajchman, zaświadczał:

Członki zwłok spalonych na rusztach na ogół się nie rozpadały. Oddzielano spalone głowy, nogi, kości itd. Brygada popielna musiała je potrzaskać specjalnymi drewnianymi kijami przypominającymi żelazne topaty, którymi tłucze się żwir na drogach. Inne narzędzia również podobne były do tych, których używa się do prac przy piachu i kamieniach. Obok stosów popiołu rozstawiono druciane siatki o małych oczkach: przesiewano przez nie rozbite popioły w taki sposób, w jaki oddziela się piach od żwiru. To, co nie przeszło przez oczka, rozbijano powtórnie. Do tego służyły blachy rozłożone nieopodal. [...] Ostatecznie "gotowy" popiół musiał być czysty, bez najdrobniejszych kosteczek i tak delikatny jak popiół z papierosa (Rajchman, 2011, s. 61$)^{51}$.

Identyczny - jeden do jednego - zestaw narzędzi był używany przez powojennych polskich eksploratorów i eksploatatorów złóż Treblinki. Obok wspomnianych już zwykłych narzędzi rolniczych. Proces technologiczny wdrożony przez Polaków po 1945 roku w pięciu innych obozach zagłady nie byt inny.

W myśl zasady hybrydyzacji w skład projektu weszło również konwersatorium: kolekcja czy nagromadzenie dialogów zasłyszanych przeze mnie nad betonem. Utrzymane w poetyce zimnej mowy nienawiści, stanowią one żywą pamięć miejsca w szczególności, a Zagłady w ogólności. Jako rodzaj mogą być łączone z „żydowskim kabaretem” - praw-

50 Henryk Grynberg i Marek Zaleski debatowali, czy ludzie zrobili to ludziom (Zaleski w ślad za Nałkowską) (zob. Zaleski, 2000), czy też ludzie zrobili to Żydom (Grynberg) (zob. Grynberg, 1984a), podczas gdy Kinga Dunin oznajmiła, iż - jak chodzi o polski udział w Zagładzie - Polacy zrobili to Żydom, jeśli nie Polacy ludziom (Dunin, 2004).

Formuła Zofii Nałkowskiej z 1946 roku „Ludzie ludziom zgotowali ten los” miała wyjściowo potencjał rewolucyjny. Jednakże polska kultura dominująca wykorzystała ją, by zatrzeć tożsamość ofiar. Dlatego też w Polsce nigdy dosyć przypominania, że „popioły były konkretne i żydowskie, a zbrodnia nie «przeciwko ludzkości», lecz przeciwko Żydom” (Grynberg, 1984b, s. 133). „Dzisiaj już wiemy na pewno, że podmiot i dopełnienie tego zdania mają inny zakres znaczeniowy, niż nam się wydawało i niż byśmy sobie tego życzyli” (Gross, 2003, s. 119) „Krytyka uniwersalizmu humanistycznego jako fałszywego uniwersalizmu pozostaje w mocy tam, gdzie uniwersalizacji nie towarzyszy wyraźne wskazanie tożsamości ofiar oraz źródeł, mechanizmów i społeczno-kulturowej legitymacji antysemityzmu,z którą wiąże się konieczność delegitymizacji nie tylko antysemityzmu, lecz także uprawomocniającej go kultury. Innymi słowy, krytyka ta pozostaje w mocy wszędzie, gdzie uniwersalizacji nie towarzyszy wskazanie na nierówne warunki dostępu do uniwersalności” (Janicka, 2014-2015, s. 182).

51 Por. także historię Forschungstation der Aktion Reinhardt w Chełmnie nad Nerem (Kulmhof am Ner) oraz Sonderkommando 1005 odpowiedzialnego za zacieranie śladów ciał zamordowanych Żydów (Spector, 1990). 
dziwym „kabaretem Treblinka” - którego aktorzy, straciwszy rodziny w komorach gazowych i sami bliscy zagazowania, występowali w obozie zagłady w 1943 roku przed wysoce rozbawioną załogą SS oraz żydowskimi więźniami, którzy stracili rodziny w komorach gazowych i sami byli bliscy zagazowania (dla odmiany) ${ }^{52}$. Niczym skecze z historycznego „kabaretu” obecne wymiany zdań odnoszą się do realiów miejsca - z majestatyczną profesorsko-doktorską uwerturą na czele. Choć były w tym miejscu także inne rozmowy.

\title{
VI. Niezapominajki
}

\author{
Niezapominajki \\ to są kwiatki z bajki! \\ Rosną nad potoczkiem, \\ patrzą rybim oczkiem. \\ Gdy się płynie tódką, \\ śmieją się cichutko \\ i szepcą mi skromnie: \\ „Nie zapomnij o mnie”.
}

Piosenka dziecięca do słów Marii Konopnickiej (1842-1910) śpiewana często przez Symchę Rotema „Kazika” (1924-2018)

W naszym kraju od 2002 roku, w dniu 15 maja obchodzimy Święto Polskiej Niezapominajki. [...] Wszyscy znamy tę [...] roślinkę.

„Wiadomości Zbąszyńskie” 2015 (Michalczak, 2015)

Sierpień 2005 roku. Warszawa. Biegłam. Jak zawsze. Już zresztą spóźniona. Na Rondzie ONZ stały dwie kobiety. Dwie turystki z zagranicy. W sportowym obuwiu wskazującym najprawdopodobniej na Stany Zjednoczone. Trzymały mapę, obie razem, i obracały ją we wszystkich kierunkach, zmagając się z wiatrem. Mieszkałam kiedyś na Śliskiej. Mieszkałam na Platynowej. Okolicę znam jak własną kieszeń. Każdy krawężnik. Każdy załom muru. Rzecz nie mogła długo potrwać. Dlatego zapytałam.

52 „Na wieczornym apelu Lalka już czeka z nową atrakcją. - Ponieważ w niedzielę po południu nie pracujemy, zorganizujemy teraz coś wesołego, jakiś kabaret, muzykę, śpiew, skecze, boksowanie" (Glazar, 2011, s. 126). Zob. także Wiernik, 2003, ss. 26, 29. Słynna na całą okolicę była niewolnicza orkiestra Artura Golda, podobnie jak spontaniczne koncerty na głosy improwizowane nocą przez ukraińskich strażników nadzorujących teren z wież strzelniczych. (Opowieść o obozowej orkiestrze usłyszałam 23 września 2020 roku od właściciela Przedsiębiorstwa Handlowo-Usługowego „Agro” na terenie starego cmentarza żydowskiego w Kosowie Lackim przy ulicy Szkolnej 23. Właściciel pochodzi ze wsi Guty. Urodził się w roku 1948. O orkiestrze słyszał od matki i siostry. Jego rodzina miała pole uprawne przy samym obozie). 
To nie było moje pytanie. Lecz była to jej odpowiedź. Po polsku. Z dykcją, jakiej nikt nie ma, jeśli naprawdę nie musi.

- Mieszkaliśmy przy Twardej 25. Tatuś miał gabinet przy Ogrodowej. Był też więziony na Pawiaku. Mam na imię Teresa. Właściwie Klara. Klara Teresa. A to jest moja córka. Simone.

Nie wiedziałam, ale się dowiedziałam. Że mam ucho szmalcownika. Nieomylne. Śmiercionośne. Rozpoznałam ją ${ }^{53}$.

Jak później objaśniała: „Aryjska strona. [...] Było to dla Żydów miejsce krańcowo niebezpieczne” (T. C. Masson, 2016, s. 8). „Każda napotkana osoba mogła być niebezpiecznym wrogiem, który mógł nas natychmiast zdradzić" (T. C. Masson, 2016, s. 47). UrodziŁam się po aryjskiej stronie. Po aryjskiej stronie wychowałam. Biały dzień. Ciemność przed oczami. Łoskot skrzyżowania. Ogłuszające bicie serca. Chwyciłam się kurczowo człowieka, który stał przede mną. Uścisk Teresy byt równie mocny. W tej samej sprawie, która jest dwoma różnymi sprawami - tak różnymi, że nigdy się nie zejdą - wybuchłyśmy głośnym płaczem.

Simone urodziła się w Kanadzie. Dorastała w Stanach Zjednoczonych. Podróż do Polski była dla niej pierwszym zetknięciem z Europą, choć niewątpliwie stąd pochodziła staromodna obrączka ze złota, którą nosiła na serdecznym palcu. Była to ślubna obrączka jej babci, Hanki - Bubełe, Bubu - która ją wychowała. Bo Teresa musiała uciekać. Odkąd Teresa skończyła dwa lata, walczyła na wojnie. Z Niemcami. Z Polakami ${ }^{54}$. Przez sześć lat. Cały czas na froncie. Zwyciężyła.

Cena za to zwycięstwo, za moje istnienie, tak ciężko wywalczone i zdobyte, nie jest mała; przez całe życie okupuję je bólem i bólem okupują je wszyscy, którzy mnie kochają teraz i którzy mnie kochali w przeszłości, [...] przede wszystkim zaś moja córka [...] (T. C. Masson, 2016, s. 37).

Teresa zwyciężyła. A potem musiała uciekać.

[W]szystko na rzecz i w służbie daremnego wysiłku zaprzeczania i katorżniczej pracy usiłowania, mającej na celu poskromienie niemożliwego do poskromienia naporu myśli, uczuć

53 W okupacyjnej polszczyźnie „rozpoznać” nie znaczyło 'zidentyfikować kogoś już wcześniej spotkanego', lecz 'zidentyfikować kogoś jako fantazmatycznego Żyda'.,Rozpoznawanie” tych, którzy walczyli o przeżycie po tzw. aryjskiej stronie, było morderczym antysemickim rytuałem praktykowanym indywidualnie i zbiorowo, dla pieniędzy i „bezinteresownie”. Tych, którzy czynili to dla pieniędzy, biżuterii i innych dóbr, nazywano „szmalcownikami”. „Szmalcownictwo” stanowiło nieformalną, lecz popularną i intratną wojenną profesję. Szantaż polegał na alternatywie: pieniądze albo śmierć (przez wydanie polskiej policji lub władzom niemieckim). Obie formy „rozpoznawania” - „bezinteresowna” i dla pieniędzy - stanowiły śmiertelne niebezpieczeństwo dla ofiar. Pierwsze pociągało za sobą drugie. Odarcie Żydów z pieniędzy, biżuterii i innych rzeczy nie było drobnym przestępstwem. Oznaczało bowiem pozbawienie ich wszelkiej szansy przeżycia. Warunkiem możliwości skorzystania z polskiego „biznesu pomocy” (ang. business of help, helping business), było bowiem posiadanie znacznych środków finansowych. Jako mała dziewczynka Teresa musiała stawiać czoła szmalcownikom płci obojga, będącym niekiedy jej rówieśnikami, zarówno w wojennej Warszawie, jak i na prowincji.

54 „Myślę tu o wspaniałej kreacji literackiej Jerzego Kosińskiego, jaką jest Malowany ptak; oczywiście, nie był on dobrym i miłym człowiekiem; nie był [tym, kogo w jidysz nazywa się] a mensz; rozmawiałam z nim, wiem [...] Lecz to, co napisał, choć nieprawdziwe w odniesieniu do jego własnej przeszłości, było zdumiewająco dokładne jako opis tego, co wydarzyło się w Polsce w tamtych smutnych i dziwnych czasach" (T. C. Masson, 2016, s. 17). 
i obrazów, których nie wyeliminował nawet podejmowany całe życie wysiłek pozbycia się ich na zawsze (T. C. Masson, 2016, s. 13).

Uciekała długo. Miała sześćdziesiąt pięć lat, gdy uległa wypadkowi:

Nic z tego wydarzenia nie pamiętam, podobnie jak nie pamiętam nic z następnych trzech miesięcy pobytu w szpitalu, wyjąwszy paranoiczny epizod, z którego nie mogłam się wydostać przez trzy czy cztery dni, uwięziona wewnątrz śmiertelnego strachu i obrazów Umschlagplatzu (T. C. Masson, 2016, s. 14).

To wtedy postanowiła pojechać tam, czyli przyjechać tu.

Między kaszą gryczaną z jajkiem sadzonym a czarnym kotem chłepcącym na stole kefir z filiżanki ujrzałam pocztówkę. Wypisaną 24 czerwca 1940 roku. Wysłaną dzień później. Z Warszawy do Nowego Jorku. Z wołaniem o pomoc. Lieber Bruder. Deutsches Reich. Deutsche Post OSTEN. Dwa zielone znaczki z Hindenburgiem. Nadawca Szajna Roza Fuleder. Twarda 25 mieszkania 12. Po trzech miesiącach z okładem Niemcy zarządzili utworzenie getta. Twarda znalazła się w tak zwanym małym getcie. Dwa lata później przed Jom Kipur stali na Umschlagplatzu55. Roza. Jej mąż Josef. Obok nich ostatnia z córek pozostała przy życiu: Hanka. W płaszczu. Ze swoją córką Teresą - wówczas Klarą - lat pięć. Ukrytą na plecach. Pod płaszczem. „Małe dzieci były całkowicie bezużyteczne, a więc całkowicie zbędne, narażone na niebezpieczeństwo nawet bardziej niż starzy ludzie" (T. C. Masson, 2016, s. 15):

55 Warszawska Umsiedlungsaktion czy Grossaktion była częścią Aktion Reinhardt, przemysłowej eksterminacji Żydów Generalnego Gubernatorstwa i Okręgu Białystok przez Niemców oraz ich pomocników. Wielka Akcja rozpoczęła się 22 lipca 1942 roku po tym, jak getto zostało otoczone przez Litwinów, Łotyszy i polską policję. Z samego początku więźniowie getta byli zabierani na Umschlagplatz z miejsc zamieszkania. Po tygodniu procedura została przejęta przez Niemców i ich ukraińską asystę, ponieważ Żydowska Służba Porządkowa, początkowo zmuszona przez Niemców do prowadzenia łapanki, nie wykonywała niemieckich rozkazów z wystarczającą gorliwością. Następnie, nadal w pierwszej połowie sierpnia, selekcja zaczęła być prowadzona bezpośrednio na Umschlagplatzu, gdzie wszyscy musieli się uprzednio zebrać. Jest wielce prawdopodobne, że w opowieści Teresy pojawia się czwarta faza Wielkiej Akcji - tzw. kocioł - skoro rodziny Fuleder i Alter są w tym czasie deportowane, mimo iż - zważywszy ich kapitał społeczny i status materialny - najprawdopodobniej były wyposażone w niezbędne zezwolenia na tymczasowe pozostanie przy życiu. Co więcej, Teresa używa określenia „Wielka Selekcja” i wspomina o dodatkowym, osobnym rozkazie. Rozkaz taki został wydany 5 września 1942 roku po siedmiu tygodniach nieprzerwanych masowych wywózek Żydów Warszawy do komór gazowych Treblinki.

Kocioł był wymierzony precyzyjnie w tych, którym wcześniej pozwolono pozostać przy życiu wraz z rodzinami (robotnikom przymusowym, lekarzom i pielęgniarkom, urzędnikom Gminy Żydowskiej i jej instytucji, jak również funkcjonariuszom Żydowskiej Służby Porządkowej). Tak zwana Wielka Selekcja czy Wielka Redukcja selekcja w selekcji, redukcja w redukcji - była prowadzona w co najmniej kilku punktach kontrolnych zaimprowizowanych w różnych miejscach w rejonie Umschlagplatzu. Trudno o obraz bardziej dokładny niż ten, który zapamiętała Teresa: upał, tłum, śmiertelny strach, strzelanie do ludzi, rodzice usiłujący przeszmuglować dzieci (lub porzucający je). W obliczu Wielkiej Redukcji niejednokrotnie zdarzało się, że więźniowie getta odbierali życie sobie i swoim bliskim. Lekarki ze szpitala dziecięcego otruły niemowlęta, które miały pod swoją opieką i podały morfinę starszym dzieciom, by oszczędzić im świadomości w chwili, gdy będą zabijane w tóżkach przez Niemców oraz ich ukraińskich, litewskich i łotewskich pomocników. Roza Ripin-Fuleder, babka Teresy, była najprawdopodobniej wśród 2648 osób zastrzelonych podczas kotła. Sześćdziesiąt innych popełniło samobójstwo. 339 umarło tak zwaną naturalną śmiercią z powodu nieludzkich warunków przetrzymywania, częstokroć pod gołym niebem, w kwartale ulic Smocza, Gęsia, Zamenhoffa, Szczęśliwa, Plac Parysowski. 54.269 osób zostało wywiezionych do Treblinki. Wszystko to w ciągu pięciu dni selekcji w obrębie selekcji.

Kocioł trwał od 6 do 11 września. Jom Kipur przypadał 21 września. Niemcy postanowili zakończyć Umsiedlungsaktion tego właśnie dnia przez rozstrzelanie zdecydowanej większości (2020 z 2400) funkcjonariuszy Żydowskiej Służby Porządkowej. Kocioł wypadał między Leil Selichot a Erew Rosz ha-Szana poprzedzającymi Sobotę Sobót. Prawdopodobnie dlatego pamięć Teresy kojarzyła opisywane wydarzenia z Jom Kipur. 
W mojej pamięci [...] panuje niesamowita cisza, gdy widzę dziadka, jak stoi wysoki naprzeciw stołu, ze skamieniałą twarzą, z wyprostowanym karkiem, jak gdyby patrzył gdzieś ponad. Babcia stoi obok niego, wyglądając na o wiele niższą. Wówczas rozlega się nagły, bardzo głośny wystrzał z broni palnej i babcia upada. Musiałam wspiąć się po ciele matki, bo patrzę z wysokiej perspektywy. Dziadek podnosi babcię, lecz jej głowa zwisa, i czuję, jak moja matka krzyczy i wyje. Wtedy żołnierz zaczyna szturchać dziadka końcem karabinu, żeby go odepchnąć od stołu i wepchnąć do kolumny ludzi przesuwającej się wolno, teraz wiem, do pociągu do Treblinki, a całe ciało mojej matki skręca się i wyje z bólu, który czułam każdą komórką mojego ciała. [...]

Matka zawsze mówiła, że najgorszą dla niej chwilą w czasie wojny, był wybór między próbą ratowania mnie a pospieszeniem na ratunek jej ukochanym rodzicom. Wiem, że nigdy nie mogła odsunąć od siebie czy uciec od tego koszmarnego momentu. W chwili, gdy całe jej ciało krzyczało z rozpaczy, czułam ten krzyk (T. C. Masson, 2016, ss. 15-16) ${ }^{56}$.

Przed Jom Kipur 1942 były liczne inne dni Wielkiej Akcji. W pierwszym okresie najprawdopodobniej jeszcze na Twardej:

Pamiętam stalowo siwe włosy, wydatne kości policzkowe, ciemne oczy, smutną piękną twarz, drapiące ubranie. To była moja babcia, matka mojej matki; pomieszczenie było ciemne, z brudną podłogą z surowych desek. Przypuszczam teraz, że była to kryjówka moich dziadków, gdzie wszyscy razem siedzieliśmy. Starzy ludzie i dzieci nie mieli legitymacji pracowniczych związanych z niewolniczą pracą w szopach; musieli więc nieustająco przebywać w ukryciu, a w razie odnalezienia zostaliby natychmiast zamordowani. Ta kryjówka znajdowała się pod podłogą jakiegoś budynku, ponieważ byłam uciszana i napominana, żeby się pod żadnym pozorem nie poruszyć: pamiętam uczucie paraliżującego strachu i odgłos butów oraz walenia nad nami, czasem krzyki bólu i strachu. [...] Jak chodzi o mojego dziadka, z tamtego czasu pamiętam tylko kogoś bardzo dużego, kto musiał się ścieśnić i zgarbić, żeby przejść przez otwór. Jaskrawo pamiętam go natomiast potem, na Umschlagplatzu (T. C. Masson, 2016, s. 12).

I był jeszcze jeden dzień. Ojcem Teresy, mężem Hanki, był Eljasz Alter, Elek, doktor medycyny (numerek życia), wówczas już zapewne w ostatniej siedzibie żydowskich szpitali na Umschlagplatzu. W sprawie pozostałej rodziny Alterów i Fulederów dwoił się i troił brat Eljasza, Badza, Żydowska Służba Porządkowa (numerek życia także). Teresa pamiętała Badzę sprzed wojny, jak podrzuca ją wysoko do góry i łapie na powrót radośnie. Potem pamiętała go już tylko w trwodze.

Także tamtego dnia, gdy Wujek Badza wtargnąt w pędzie, a mama z tatą, zabierając mnie ze sobą, pospieszyli w panice za nim, ku szerokiej kolumnie ludzi poganianych pejczami przez uzbrojoną straż do oczekującego pociągu. Moi dziadkowie (rodzice ojca) i siostry mojej matki z mężami, wszystkie moje ciotki i wujowie, wyjąwszy Wujka Badzę, zostali zabrani i byli ładowani do bydlęcych wagonów. Wszyscy mieli przy sobie walizki i ciężkie tłumoki z rzeczami. [...] Ojciec i Wujek Badza stali nieopodal i cicho płakali; nie mogli nic zrobić. Nagle Wujek

56 Było to doświadczenie typowe wśród tych, którzy przeżyli kocioł i inne wywózki. Henryk Makower, lekarz Żydowskiej Służby Porządkowej, straciwszy w kotle całą rodzinę, pozostał zatrzaśnięty na resztę życia w podobnym momencie: „Tłumaczę się sam przed sobą ze swego postępowania, wiem, że takie były realia, ale wtedy miałem tylko uczucie rozpaczy i w ogóle nie myślałem. Dwie nieprzespane noce i dwa dni największego nerwowego napięcia po 7 tygodniach wysiedlenia i po 3 latach wojny, to trudno sobie wyobrazić. W każdym razie nie ulega wątpliwości, że tego wielkiego egzaminu życiowego jako syn i brat nie zdałem. [...] To nie jest tylko czarna plama w moim życiu, które było dotychczas uczciwe i porządne, ale jest to stały wyrzut sumienia, trapiący mnie w każdej chwili, gdy widzę przed oczyma moje drogie twarze. Widzę je często w dzień, w nieprzespane noce, we śnie" (Makower, 1987, ss. 125, 127). 
Badza zerwał się, mówiąc, że wie, co zrobić. I nigdy więcej go już nie zobaczyliśmy (T. C. Masson, 2016, ss. 19-20).

Przy herbacie Earl Grey i szarlotce (szara reneta, rodzynki, orzechy włoskie, kruche ciasto, kruszonka) ujrzałam na fotografii twarz Rozy (Twarda 25 mieszkania 12), która na żeliwnej blasze kuchennego pieca robiła grzanki ze starego chleba moczonego w ersatzu kawy dla swojej wnuczki Teresy, wówczas jeszcze Klary. Grzanki francuskie to się nazywało. Gettowy delikates. Zobaczyłam Elka. Zobaczyłam siostry Fuleder: Hankę, Rut i, szczególnie przez Hankę ukochaną, Ester. To po Ester dostała Simone swoje hebrajskie, drugie imię. „Ona także jest ocalałą” (T. C. Masson, 2016, s. 37). (Simone Esther. Nie Ester. Ester nie przeżyła). W trzyczęściowym garniturze, wyprostowany - faktycznie wysoki na fotograficznym tle malowanym w gotyckie ruiny i tajemnicze chaszcze, trwał, patrząc prosto w obiektyw, dziadek Teresy - wtedy jeszcze Klary - Josef, właściciel majątku w Golubiu Dobrzyniu, gdzie się urodziła.

Teresa i Simone przestały przyjeżdżać podczas Wielkiej Recesji, gdy dom Teresy i jej żony Debory w Kalifornii został zajęty przez bank, który dokonał przejęcia ich banku. Jako prawniczka Teresa stała się niezmordowaną rzeczniczką właścicieli domów postawionych w tej samej sytuacji, kolejnej grupy społecznej ubezwłasnowolnionej przez turbokapitalizm, którego nienawidziła. Już sam turbokapitalizm by wystarczył. Ale to nie było wszystko. To była opcja dwa w jednym. Teresa nie odpuszczała nawet na chwilę. Jej odpowiedź brzmiała zawsze tak samo:

- Nie mogę przyjechać. To jest Deutsche Bank.

Z Nowej Zelandii przyjechał natomiast Jeffrey. Ojciec Simone. Niegdysiejszy mąż Teresy. Ekspert od sanskrytu i Freuda. Działacz na rzecz praw zwierząt. Urodzony i wychowany w Stanach Zjednoczonych. Rodzina z Buchary. Bez wstępów zapytał o Twardą 25, choć wiedział już, że nie istnieje. Większość czasu spędziliśmy tam właśnie, w łoskocie Ronda ONZ. Jeff był w Polsce bardzo krótko, więc nie chciał trwonić czasu na rzeczy nieistotne. Chciał zrozumieć coś, co i tak rozumiał, bo kochał Teresę i Simone.

One same przyjechały, gdy Teresa zaczęła czuć się gorzej, słabła. Późną jesienią 2014 roku. We trzy. Teresa. Simone. Deborah. W Warszawie akurat otwierało się coś, co zapowiadano jako Muzeum Historii Żydów Polskich, a co w ostatniej chwili przemianowano na Muzeum Polin. Muzeum Polska. Teresa myślała zrazu, że to żart. Jednakże w środku, na dole, gdzie umieszczono wystawę główną, z rozpoznawanej stała się tą, która rozpoznaje. Tak powiedziała: „Poznaję. To jest Polska. Polska, z której uciekaliśmy, nie czekając już nawet na pogrom kielecki. Ta sama. Nic się nie zmieniła" ${ }^{57}$. Simone miała przy sobie

57 „Tuż przed otwarciem spotkałyśmy młodego mężczyznę, który pracował dla Muzeum, i gdy powiedziałyśmy, że mama przyjechała do Warszawy na otwarcie, że przeżyła getto warszawskie jako dziecko, usłyszałyśmy, że nie zostaniemy dopuszczone do inauguracyjnego przyjęcia, ponieważ nie można oczekiwać - przecież - że zaproszenia obejmą «wszystkich ocalałych», którzy mogliby wrócić i chcieć być obecni” (S. E. Masson, 2016, s. 3) 
na kartce kadysz w wersji świeckiej wydrukowany z Internetu. Kartka się przydała. Z pewnością nie był to pierwszy kadysz zmówiony w tym miejscu, pod ziemią ${ }^{58}$.

Teresa chciała pożegnać się z rodziną. Spróbować przynajmniej. Całe życie nie była w stanie. Poszłyśmy na Umschlagplatz. Pojechałyśmy do Treblinki. U wejścia, na ścieżce, na środku, siedział lis pochłonięty gruntowną toaletą. Nasze nadejście zignorował. Nie przeszkadzał sobie. W końcu jednak wstał. Przyglądał nam się długo. Bardzo długo. Uczynił kilka niespiesznych kroków w stronę ściany lasu. Zatrzymał się. Raz jeszcze zlustrował nas dokładnie. Po czym wkroczył dostojnie w zarośla wzdłuż północnej granicy byłego obozu.

Po drodze Simone chciała wiedzieć, czy na miejscu rosną niezapominajki. Powiedziałam, że tak. Zgodnie z prawdą.

- Pokażesz mi?

- Wiosną rosną. Teraz jest koniec października.

Niezapominajki były ulubionymi kwiatami Hanki. W ich widoku zawierało się wszystko i wszyscy. Golub Dobrzyń. Kutno. Rodzice Roza i Josef. Siostry Ester i Rut. Studia w Liège z powodu numerus clausus w Polsce. (W Liège Hanka spotkała Elka. Tam się w sobie zakochali). Dalej więc także rodzina Alterów, właściciele majątku w Pławnie. I Pławno. I Twarda 25 mieszkania 12. Jeszcze jako szczęśliwe czasy, kiedy wszyscy żyli, byli. A potem... Wielka Akcja. I cała reszta.

Gdy lis się oddalił, Simone podjęła decyzję.

- To pokaż mi, proszę, miejsce, w którym rosną, gdy jest wiosna.

Widziałyśmy się wówczas po raz ostatni. Teresa umarła niecałe dwa lata później nad Zatoką San Francisco. Jej prochy zostały rozsypane w cieśninie wiodącej do Pacyfiku.

58 W miejscu dzisiejszego Muzeum Polska znajdowała się ostatnia siedziba Judenratu (od końca 1942 roku) oraz kamienica o adresie Zamenhoffa 38. W podwórkach kamienicy istniały co najmniej dwa domy modlitwy. „Chone Shmeruk, historyk literatury, który spędził część dziecinstwa w tym domu, zapamiętał jedną salę modlitwy należącą do chasydów z Kocka, i drugą utrzymywaną przez grupę krawców [por. My Warsaw is gone... Professor Chone Shmeruk interviewed by Monika Adamczyk-Garbowska, „Więż” 1998 (numer specjalny: Under one heaven: Poles and Jews), ss. 326-333]. [...] Możliwe, że jeden z opisanych przez Shmeruka domów modlitwy pozostat czynny po rozpoczęciu nazistowskiej okupacji i zamknięciu warszawskiego getta. Takie miejsce modlitwy widział w tej kamienicy Hillel Seidman, historyk i działacz żydowskiej społeczności ortodoksyjnej. W styczniu 1943 roku, pięć miesięcy po wielkiej akcji likwidacyjnej, Seidman został zaproszony do odwiedzenia tego miejsca przez grupę studentów jesziwy, którzy poprowadzili go do ukrytego wejścia przez szereg strychów i zamkniętych pomieszczeń znajdujących się w sąsiednich domach, aby ostatecznie wskazać mu właz do bunkra ukryty w piecu znajdującym się w kamienicy przy Zamenhofa 38. Seidman opisuje świetnie zaopatrzoną kryjówkę, posiadającą dostęp do wody i elektryczności, w której trwały wciąż studia religijne [por. Hillel Seidman, Du fond de l'abîme: journal du ghetto de Varsovie (Paris: Plon,1998), ss. 180-188]. Nieomal pewne jest, że bunkier ten został zniszczony trzy miesiące później, krótko po wybuchu powstania w getcie warszawskim. Pierwszego dnia walk, 19 kwietnia 1943 roku, kamienicę podpalili naziści; wiadomo, że wewnątrz zginęło wiele osób [por. B. Schieb, M. Voigt, \& F. Weinstein, Aufzeichnungen aus dem Versteck: Erlebnisse eines polnischen Juden 1939-1946 (Berlin: Lukas Verlag, 2006), s. 526]" (Matyjaszek, 2016, s. 28). Podczas Gross Aktion Warschau w 1942 roku więźniowie getta kryli się - i modlili - także w budynku dawnych Koszar Wołyńskich, które po Wielkiej Akcji stały się ostatnią siedzibą Judenratu. 


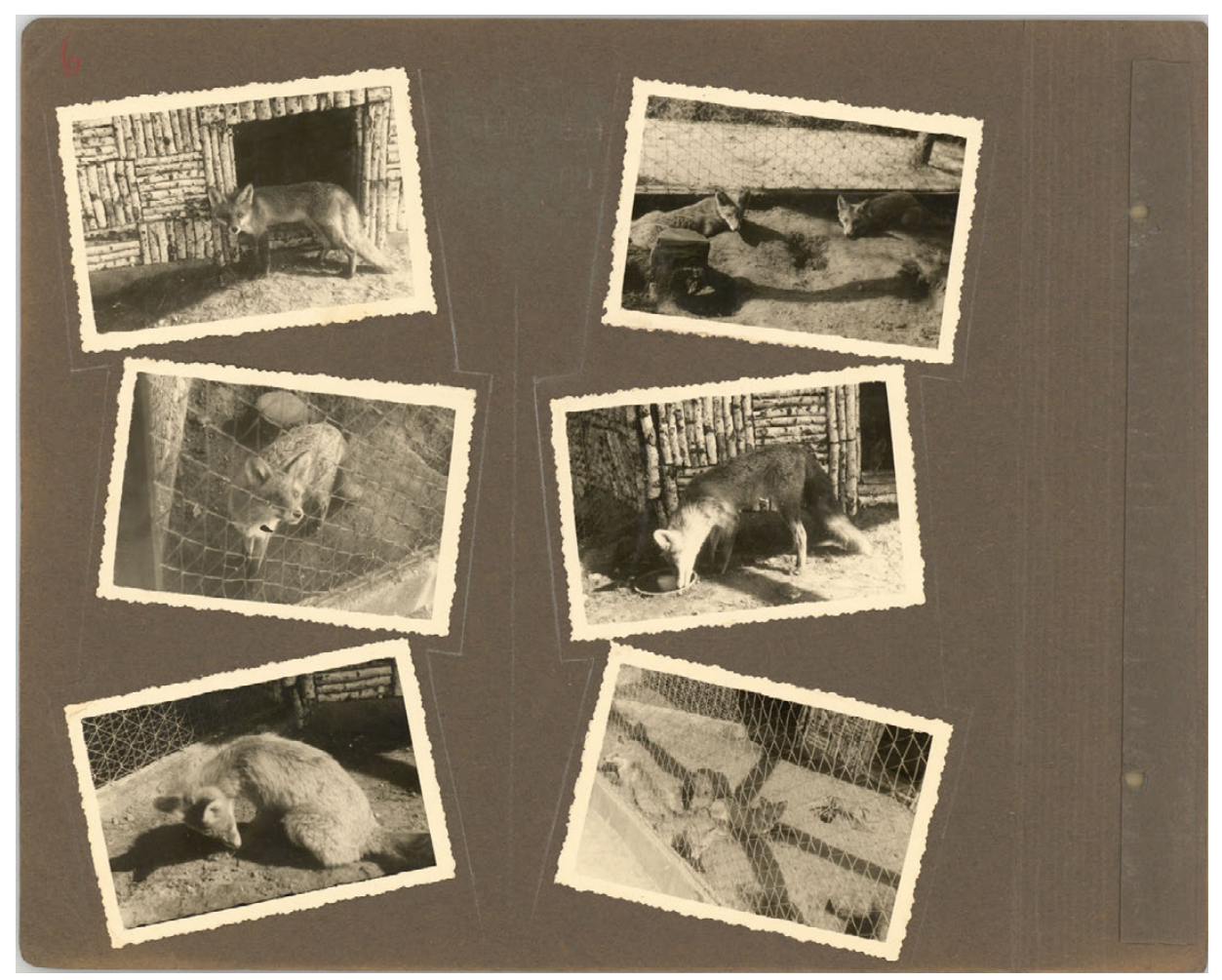

Lisy uwięzione w ZOO na terenie Treblinki II w obiektywie Untersturmführera SS Kurta Franza, zastępcy i następcy komendanta obozu Hauptsturmführera SS Franza Stangla, rok najprawdopodobniej 1943 - karta szósta albumu fotograficznego Kurta Franza (z zasobu Staatsanwaltschaft Düsseldorf, dzięki uprzejmości Landesarchiv Nordrhein-Westfalen Abteilung Rheinland - RWB 18244a_0006). Specjalne podziękowania dla Katrin Stoll

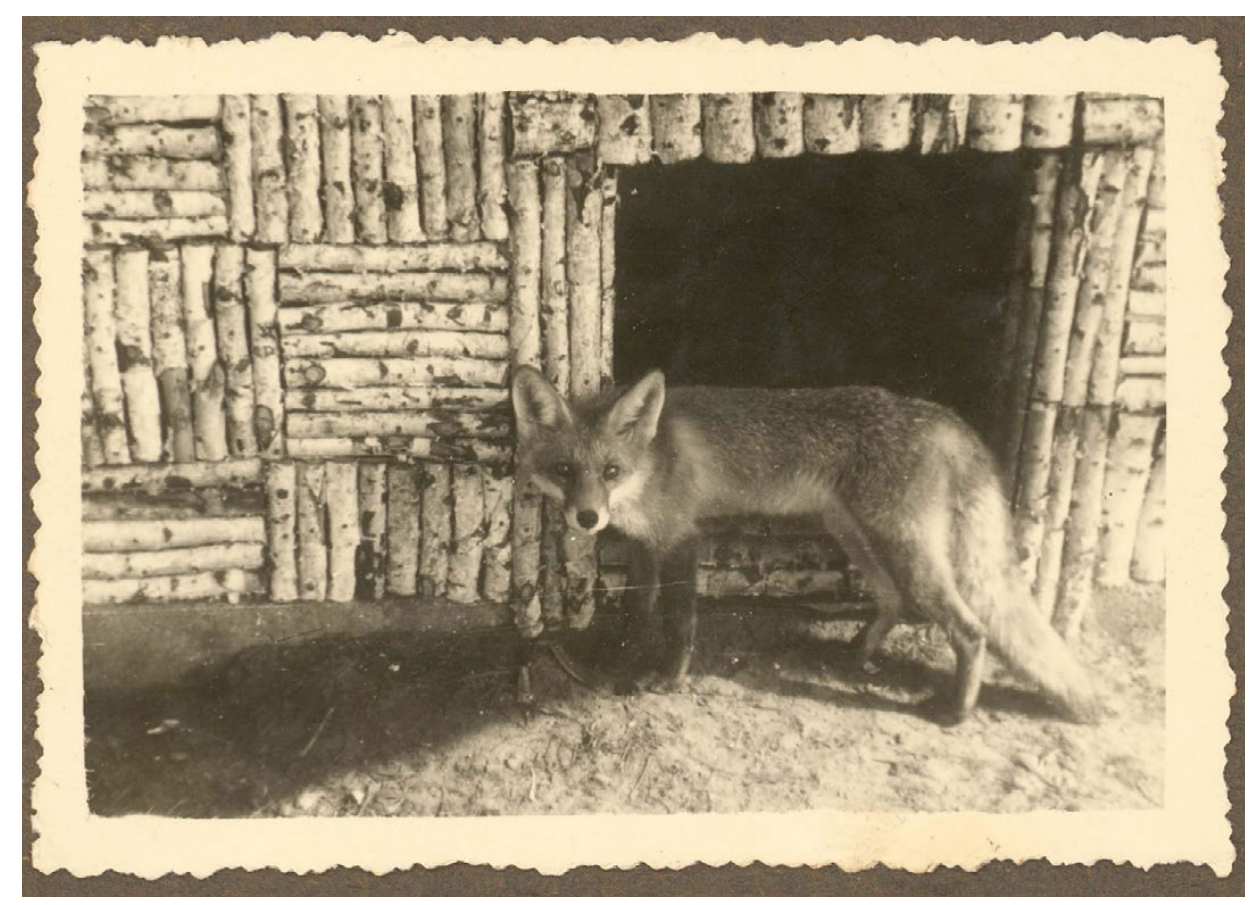

Pierwsze z sześciu zdjęć z karty szóstej albumu fotograficznego Kurta Franza - Treblinka II, rok najprawdopodobniej 1943 (fot. Kurt Franz) (z zasobu Staatsanwaltschaft Düsseldorf, dzięki uprzejmości Landesarchiv Nordrhein-Westfalen - Abteilung Rheinland - RWB 18244b_0033). Specjalne podziękowania dla Katrin Stoll 


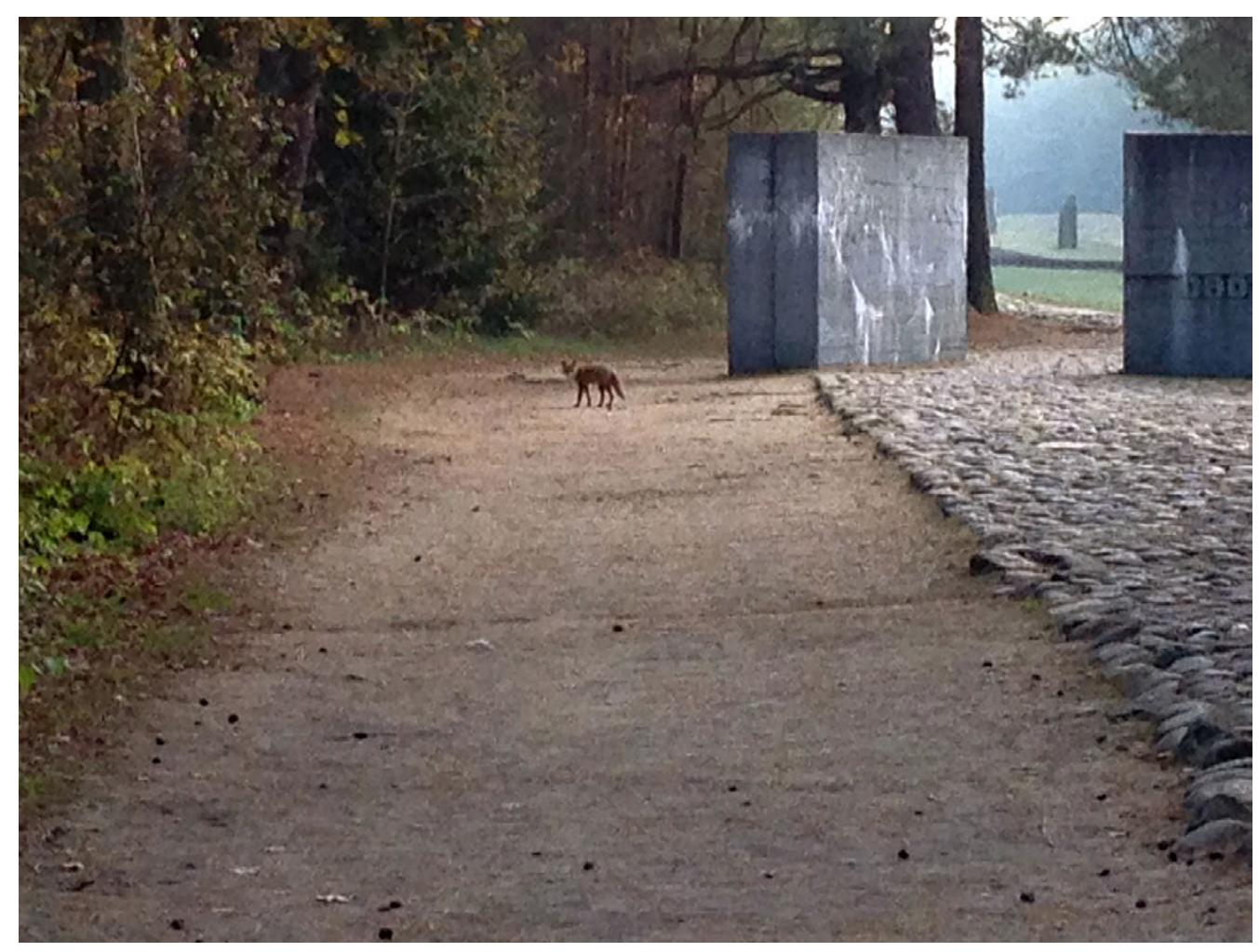

Lis u wejścia na teren byłego obozu zagłady - Treblinka II, 30 października 2014 (fot. Simone Esther Masson) (๔ by Simone Esther Masson, dzięki uprzejmości Autorki zdjęcia)

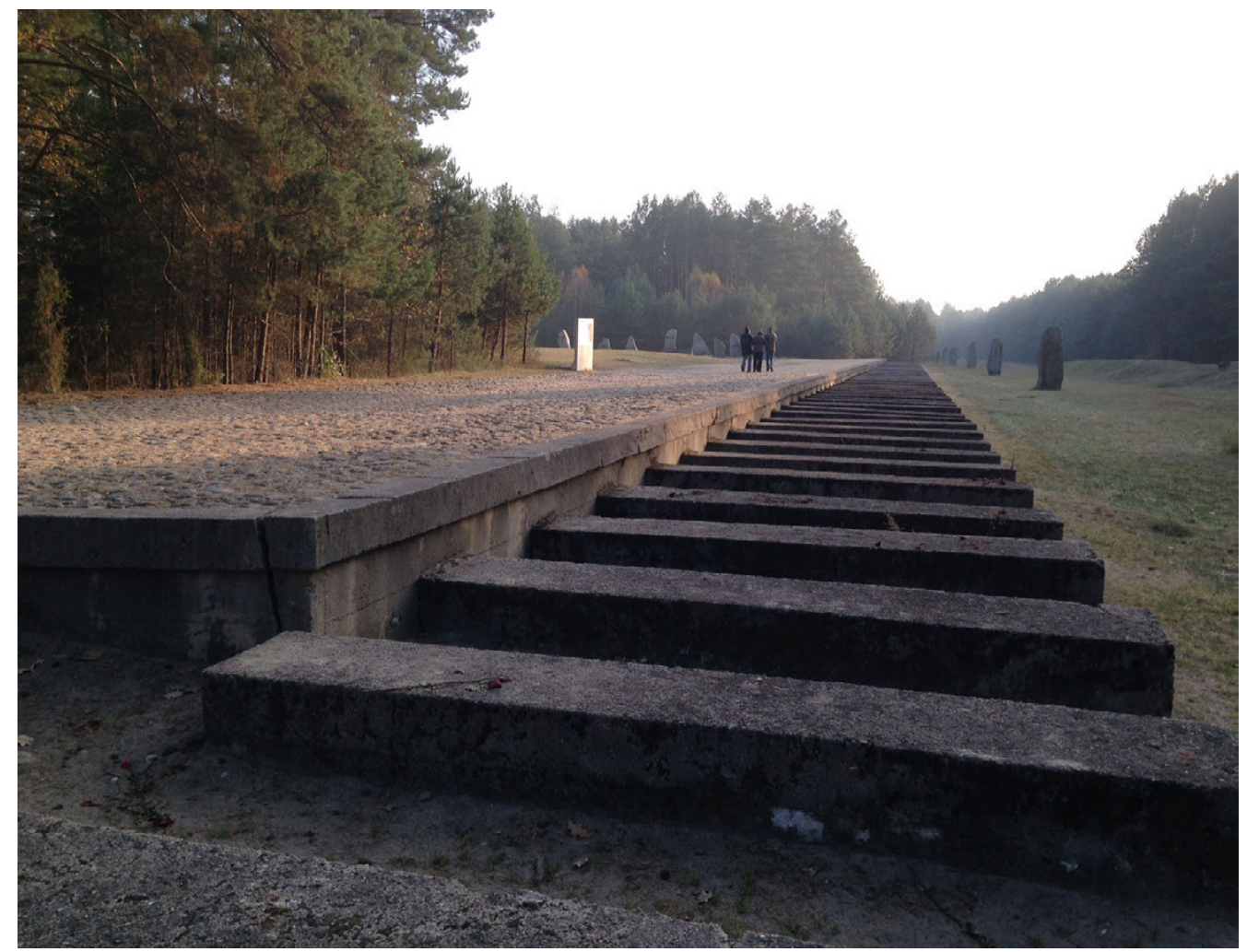

Klara Teresa Alter z córką Simone Esther Masson (z prawej) i Elżbietą Janicką (z lewej) - Treblinka II, 30 października 2014 (fot. Deborah Kenoyer) (๔ by Deborah Kenoyer, dzięki uprzejmości Autorki zdjęcia) 


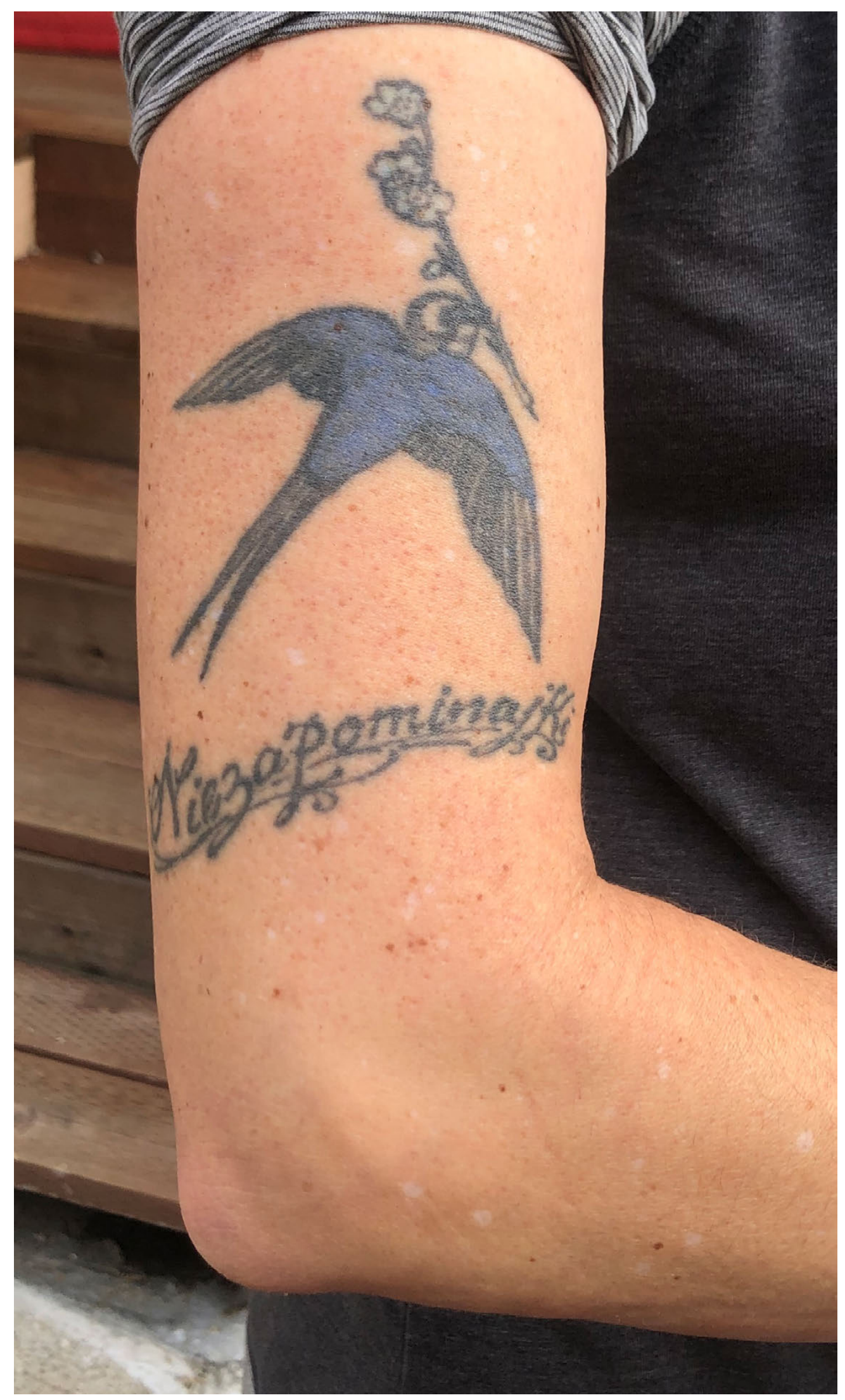

Tatuaż Simone Esther Masson - Oakland, CA, 21 marca 2020 (fot. Jaime Beth Levy) (๔ by Jaime Beth Levy, dzięki uprzejmości Autorki zdjęcia) 


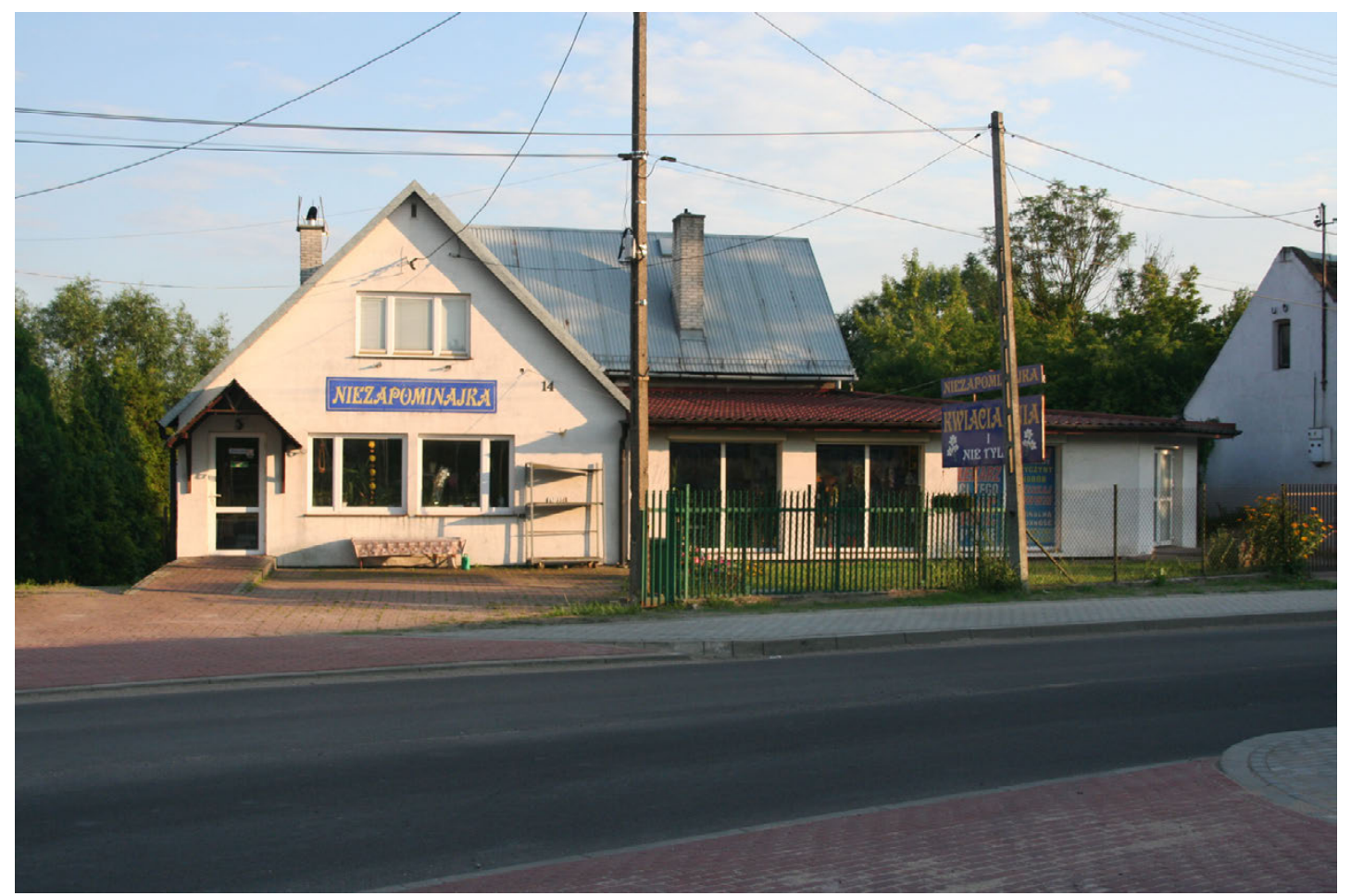

Kwiaciarnia „Niezapominajka” przy drodze wylotowej na Treblinkę - Nurska 14, Małkinia Górna, 15 lipca 2020 (fot. Elżbieta Janicka)

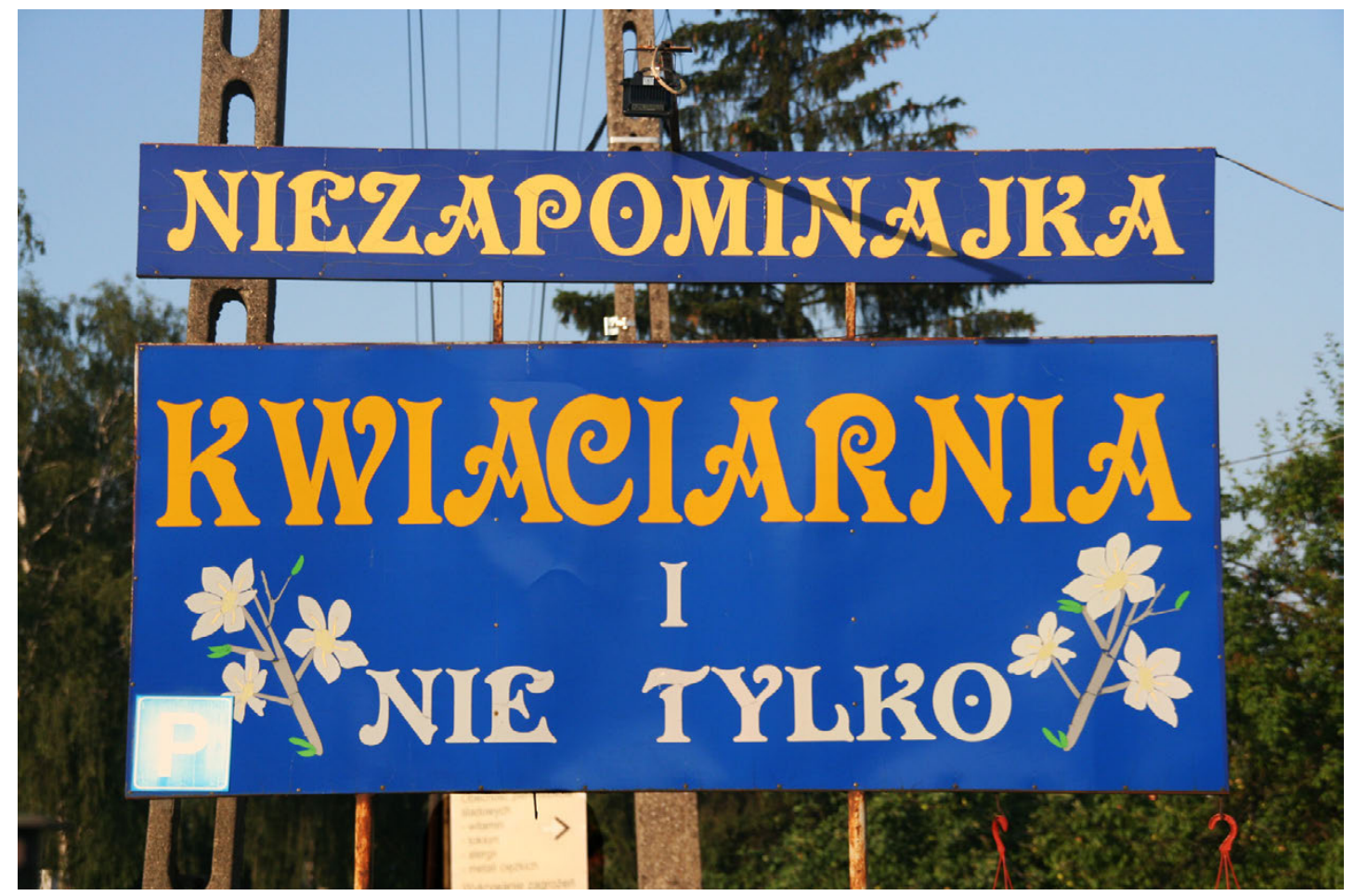

Szyld kwiaciarni „Niezapominajka” - Nurska 14, Małkinia Górna, 15 lipca 2020 (fot. Elżbieta Janicka) 
Zanim wyjechały, przyjrzałam się tatuażowi na ramieniu Simone. Była to jaskółka trzymająca w dziobie łodyżkę drobnych bladoniebieskich kwiatków z żółtym środkiem. I jedno słowo pod spodem. Po polsku. Niezapominajki.

Niezapominajki to są kwiatki z bajki.

\section{Kolejny wycinek}

\section{Lapidarium}

Przedostatnią część projektu stanowi lapidarium. Można w nim widzieć nawiązanie do fuzji botanicznego z geologicznym, jaką przeprowadziła Róża Luksemburg. Wszelako jeszcze jeden argument należy przywołać na tym skrzyżowaniu. W Internecie została upubliczniona spuścizna Krzysztofa Junga. Będąc wizjonerem sztuki ciała, Jung praktykował także rysunek i malarstwo. Zostawił po sobie ponadto archiwum fotograficzne zawierające między innymi fotograficzne szkice i studia do obrazów. Lata temu w katalogu jego pośmiertnej retrospektywy natrafiłam na zdjęcie, które zrobił mu Wojciech Karpiński 16 sierpnia 1991 roku (Sitkowska, 2001, s. 211). W klapkach (szczegół ważny z uwagi na rodzaj kontaktu z podłożem, jaki zapewniają), z aparatem w dłoniach, Jung klęczy na betonie Treblinki wśród kamieni. Najpewniej w tylnej części byłego Totenlager.

Obserwacja natury inspirowała najważniejsze z jego prac. Znana była jego namiętność do owadów, płazów i gadów, z którymi dzielił życie i mieszkanie. Treblinka zaś jest prawdziwym vivarium udzielającym schronienia wielu z nich. Zwłaszcza beton i szczeliny rozdzielające betonowe płyty zaskarbiły sobie uznanie płaziej i gadziej publiczności. Przez wszystkie te lata zastanawiałam się, co też takiego Krzysztof Jung, tak czuły na wszelkie drgnienie ożywionego świata, zobaczył przez obiektyw aparatu. Jaki rodzaj miejsca napotkał? Dowiedziałam się tego w końcu dzięki nowo powstałej stronie w Internecie.

Rezultatem podróży Junga do Treblinki było pięć fotograficznych studiów (Jung, b.d.). Dwa z nich są formalnymi wariacjami na temat krajobrazu, uchwyconymi okiem rzeźbiarza lub projektanta przestrzeni. Dwa inne wydają się przypadkowe. $\mathrm{Na}$ jednym to, co wydaje się najważniejsze - menora z megalitu - pojawia się zdecydowanie z lewej strony, destabilizując spojrzenie i cały proces percepcji. Drugie wydaje się zupełnie pozbawione punktu centralnego. To wrażenie utrzymuje się do momentu, w którym widz wytyczy środek obrazu i zacznie mu się przyglądać. Oba kadry okażą się wówczas skonstruowane wokół roślin. Jung wybrał gatunki postrzegane zazwyczaj jako zbyt pospolite i przeciętne, by zasługiwały na bycie centrum czegokolwiek: szczaw (Rumex acetosella) i mniszek pospolity (Taraxacum officinale) w stadium dmuchawca. 
Ostatnie ze studiów polega na portrecie większego, ciemnego kamienia otoczonego przez kilka mniejszych, jasnych. Scena - niczym fraktal - powtarza główny wzór upamiętnienia: megalityczna bryła główna w otoczeniu głazów pobocznych. Innymi słowy, Krzysztof Jung nadał organicznemu i mineralnemu równorzędny status, uznając je za konstytutywne dla miejsca w równym stopniu. Jego artystyczne wybory związane z naturą nie chybiały celu. Mając takich poprzedników, nie mogłam być już bardziej pewna własnego gestu.

Materialny związek lapidarium z miejscem jest bezpośredni. Za sprawą żwirowni obsługiwanej przez obóz pracy niewolniczej Treblinka I i usytuowanej między dwoma obozami. A także za sprawą łączącej obozy Czarnej Drogi. Obie te części dzisiejszego pejzażu Treblinki zawierają kamień - surowy materiał naturalnie nieruchomy, kulturowo przemieszczalny i z zapałem przemieszczany. Kamienie są rozmaitego pochodzenia. Najbliższy związek z miejscem ma żwir z pobliskiego wyrobiska. Posłużył on za podkład pod Czarną Drogę, która swe imię wywodzi właśnie od jego czerni, żywo kontrastującej z otaczającym „piaskiem o świetlistej żółtej barwie”, jak pisał Richard Glazar (Glazar, 2011, s. 144) $)^{59}$.

Nawierzchnię Czarnej Drogi stanowią jednakże kamienie z nieco dalszej okolicy: z Kosowa Lackiego, miasteczka ze wspomnianą już mleczarnią, byłego sztetla od wciąż aktualnego El Greca. Wśród kamieni Czarnej Drogi dominuje granit polny. (Po łacinie by się powiedziało granites arvus). Użyty materiał nie był jednakże całkiem surowy. Przed potłuczeniem na kawałki kamienne bloki były polerowane i rzeźbione. Ich źródło stanowiły żydowskie cmentarze Kosowa Lackiego: stary przy ulicy Szkolnej i nowy przy drodze do Sokołowa Podlaskiego. Choć zmarli nie ruszyli się z miejsca, cmentarze te nie wyróżniają się dzisiaj z otoczenia za sprawą powojennego polskiego wkładu w dzieło

59 Wasilij Grossman pisze: „Popioły zwłok wyrzucano poza ogrodzenie obozu [Treblinka II - E. J.].W tym też celu zmobilizowano chłopów z Wólki [Okrąglik - E.J.]; tadowali popioły na wózki-wywrotki, które następnie opróżniali wzdłuż drogi, wiodącej do obozu Nr 1. Dzieci więźniów rozrzucały te popioły po drodze. Czasami znajdowały w tych popiołach monety lub złote zęby. Dzieci te nazywano «dziećmi czarnej drogi». Droga ta na skutek rozsypywania po niej popiołów, stała się czarna jak wstążka z krepy” (W. Gros[s]man, 1945, s. 27). Dokonana przez Grossmana rekonstrukcja nie jest dokładna. Gospodarze - Grossman nazywa ich więźniami, którymi ci nie byli - nie mogli przedostawać się na teren Treblinki II pod niemieckim panowaniem. W rzeczywistości gospodarze z Wólki Okrąglik i okolicznych wsi - wraz z dziećmi, z którymi miałam okazję rozmawiać po latach - systematycznie eksploatowali pola prochów Treblinki II po wycofaniu się Niemców.

W końcu lat dziewięćdziesiątych „Na zlecenie Rady Ochrony Pamięci Walk i Męczeństwa została także poddana analizie próbka ziemi z tzw. Czarnej Drogi. Istniało podejrzenie, że może ona zawierać prochy ludzkie, jednak badania nie stwierdziły obecności szczątków organicznych" (Zawadka, 2015, s. 52).

Relacja Grossmana o Treblince figuruje także w Czarnej księdze, którą współredagował z Ilją Erenburgiem (Erenburg \& Grossman, 2020; W. Grossman, 2020). Artykut z YIVO Encyclopedia of Jews in Eastern Europe (Ro'i, 2010) nie wspomina, że oryginalna wersja Czarnej księgi - koncepcji Erenburga i Grossmana - pomijała te spośród materiałów zebranych przez Żydowski Komitet Antyfaszystowski, które dotyczyły litewskiego i ukraińskiego udziału w Zagładzie. Podobnie w Życiu i losie, w relacji dotyczącej Zagłady od kul w jego rodzinnym Berdyczowie, Grossman obciążył Niemców wyłączną odpowiedzialnością za mord na Żydach, oszczędzając jego ukraińskich uczestników - zarówno cywilnych, jak mundurowanych (W. Grossman, 2009). Ten sam wzór operacja oszczędzająca nie-niemieckich aktorów wydarzeń - manifestuje się w jego relacji na temat Treblinki. 
unicestwienia, zainaugurowane przez Niemców podczas wojny ${ }^{60}$. Bo Czarna Droga powstała właśnie wtedy. Z żydowskich nagrobków.

Osobą, która się jeszcze w tym nie połapała, jest dyrektor Muzeum Walki i Męczeństwa w Treblince, Edward Kopówka, który w swym referacie naukowym pisze: „Kamienie zbierano na okolicznych polach" (Kopówka, 2013b, s. 54). Co może być prawdą, jeśli żydowskie cmentarze zakwalifikuje się jako pola, jak to powszechnie miało miejsce w powojennej Polsce. Trzeba przyznać, że Edward Kopówka nie jest specjalistą od historii obozu zagłady Treblinka II. Jego specjalność stanowi historia obozu pracy niewolniczej Treblinka I. Wszelako nie wydaje się, by to coś pomagało. Opisując likwidację obozu pracy, Kopówka wyraża się jasno:

Polaków zamknięto w baraku, natomiast teren zajmowany przez Żydów SS-mani i strażnicy otoczyli kordonem. Wszystkim Żydom rozkazano wyjść z baraków i położyć się twarzą do ziemi. W żydowskiej części obozu było wówczas około 550 osób, w tym kobiety i dzieci. Około 17 osób, niezbędnych fachowców, odłączono od tej grupy i zatrzymano w obozie. Pozostałych więźniów [żydowskich - E. J.] strażnicy wyprowadzali małymi grupkami do lasu i tam rozstrzeliwali (Kopówka, 2013b, s. 59).

W konsekwencji: „Zbiorowe mogiły upamiętniono 112 krzyżami betonowymi o wys. $1 \mathrm{~m}$, a w miejscach mogił pojedynczych ustawiono 12 krzyży” (Zawadka, 2015, s. 46). Ostatecznie, jak pisze Kopówka, podczas likwidacji obozu „Rozstrzelano również około 20 polskich więźniów, w tym kobiety i dzieci” (Kopówka, 2013b, s. 60). I być może dlatego dyrektor patronuje instalacji dalszych krzyży. „Obecnie liczba krzyży wzrosła do 140” (Kopówka, 2013b, s. 60). Jako gospodarz miejsca gości też drogę krzyżową polskiej młodzieży i inne katolickie praktyki religijne na terenie Treblinki I.

Pomysłodawcami Czarnej Drogi byli niemieccy i austriaccy naziści. Wykonawcami zaś żydowscy więźniowie obozu pracy niewolniczej Treblinka I. W myśl rozkazu mieli oni kłaść fragmenty nagrobków napisami do ziemi. Niektórzy jednak dali radę uczynić odwrotnie. Starałam się udokumentować rezultat wszystkich anonimowych usiłowań zwieńczonych „sukcesem”, pamiętając o tych - niepoliczonych i już nie do policzenia które się nie powiodły.

Kładzenie okruchów i większych kawałków macew inskrypcją do góry było aktem niesubordynacji okupionym ryzykiem natychmiastowej śmierci. Buntem przedsięwziętym dla samego gestu. Intencją pozostawienia wiadomości bez cienia nadziei, że zostanie ona rozpoznana jako taka i odebrana przez integralnie wrogie otoczenie (zob. Krze-

60 „W Kosowie były dwa cmentarze żydowskie: starszy, co najmniej XVIII-wieczny - na terenie ówczesnego Kosowa Ruskiego, oraz nowy - na południe od Kosowa Lackiego. Obydwa zostały doszczętnie zniszczone podczas II wojny światowej" (Canin, 2018b, s. 239, przyp. 201). Retoryka przytoczonego przypisu jest typowa dla polskiego dyskursu antysemickiego, który pomija tożsamość sprawców tam, gdzie w zbrodnie na Żydach uwikłani byli Polacy. Inny wariant polega na przypisywaniu całej odpowiedzialności Niemcom, a więc na zacieraniu polskiego kontekstu danego przestępstwa. Retoryka ta zaczęła zanikać po debacie jedwabieńskiej z 2000 roku, po czym została na powrót zalegitymizowana po akcesji Polski do Unii Europejskiej w roku 2004. Przypisy do książki Canina zostały opracowane przez troje autorów. Udało mi się ustalić, że autorką przypisu 201 nie (sic!) była Ewa Koźmińska-Frejlak. Na temat żydowskich cmentarzy w Kosowie Lackim por. także Krzysztofa Bielawskiego Zagłada cmentarzy żydowskich (Bielawski, 2020, ss. 37, 47). 
picki, 2017, s. 125). Odsyła to bezpośrednio do polskiego kontekstu Zagłady. Niemiecki nazistowski modus operandi znacząco różnił się od lokalnej chrześcijańskiej - polskiej katolickiej - tradycji destruowania żydowskich cmentarzy i recyclingu macew. Mam na myśli zwyczaj kładzenia ich inskrypcją do góry z zamiarem ich uwidocznienia. Dlaczego Niemcy mieli obiekcję w stosunku do czegoś, co było zwyczajne dla Polaków? „Może ich te hebrajskie litery denerwowały? I paradoksalnie dzięki temu macewy są świetnie zachowane. Zdarza się nawet, że przetrwały na nich kolorowe polichromie" (Kowalska, 2012, s. 21).

Zagłada Żydów bywa zazwyczaj opisywana w kategoriach masowego zabijania. Ten opis, choć zgodny z prawdą, jest obarczony ryzykiem rozmycia faktu, że masowe zabijanie wymagało indywidualnego zabicia każdej osoby zdefiniowanej jako Żyd w jakikolwiek sposób przez kogokolwiek chrześcijańskiego pochodzenia. Trzeba zatem nieustannie uważać i bez przerwy problematyzować sposób, w jaki myślimy o eksterminacji. Czy też - bardziej wprost - trzeba myśleć o eksterminacji w sposób wahadłowy. Przechodząc od zbiorowego do indywidualnego i na odwrót.

Ginąc indywidualnie, Żydzi - podobnie jak ich niemieccy i polscy wrogowie - byli w pełni świadomi, że są celem ataku jako zbiorowość definiowana z zewnątrz według najrozmaitszych, lecz zbieżnych kryteriów: teologicznych, ideologicznych, „naukowych”. Wszystkie one były kryteriami kulturowymi, nie wyłączając aspirujących do obiektywizmu i naukowości utopii rasistowskich. Niezależnie od kryteriów definicyjnych, nosiciele żydowskiego piętna byli postrzegani jako zdatni jedynie do usunięcia - biologicznie i kulturowo. Temu też mieli okazję świadkować podczas Akcji Reinhardt, patrząc na niemiecką nazistowską i polską katolicką furię zniszczenia - wykraczającą dalece poza morderstwo i kradzież - wymierzoną także w ślady ich istnienia, indywidualnego i zbiorowego. Bo Zagłada to sytuacja, w której śmierć nie wystarcza.

Czarna Droga jest traktatem o unicestwieniu: biologicznym i kulturowym, indywidualnym i zbiorowym. Litery, sylaby, kilka słów, jedno imię. Konotują jednostkowy charakter gestu sprzeciwu: jednostkową decyzję, za którą stało istnienie poszczególne wystawiające się na ryzyko natychmiastowego nieistnienia. Jednocześnie zaś odsyłają do jednostkowej abnegacji właściwej przyjętej formie ekspresji. Oto bowiem jednostki odarte z imion, wyrażające siebie poprzez pozostałości imion innych, nieznanych sobie jednostek. Rzecz jasna, ten sposób wyrazu był wyborem bez wyboru, czyli tym, co Lawrence L. Langer nazwał a choiceless choice (Langer, 2015, s. 94). Był to wybór jedynego dostępnego sposobu artykulacji podmiotowości w świecie opartym na negacji zasady, że „Każdy człowiek ma imię" (Zelda). I właśnie dlatego przyjęcie tej formy ekspresji - gdzie jednostka abdykuje, wpisując się w zbiorowość - jest obciążone krańcowym ryzykiem potwierdzenia reguł podyktowanych przez oprawcę, który narzuca ofierze tożsamość niezależnie od jej autodefinicji. 


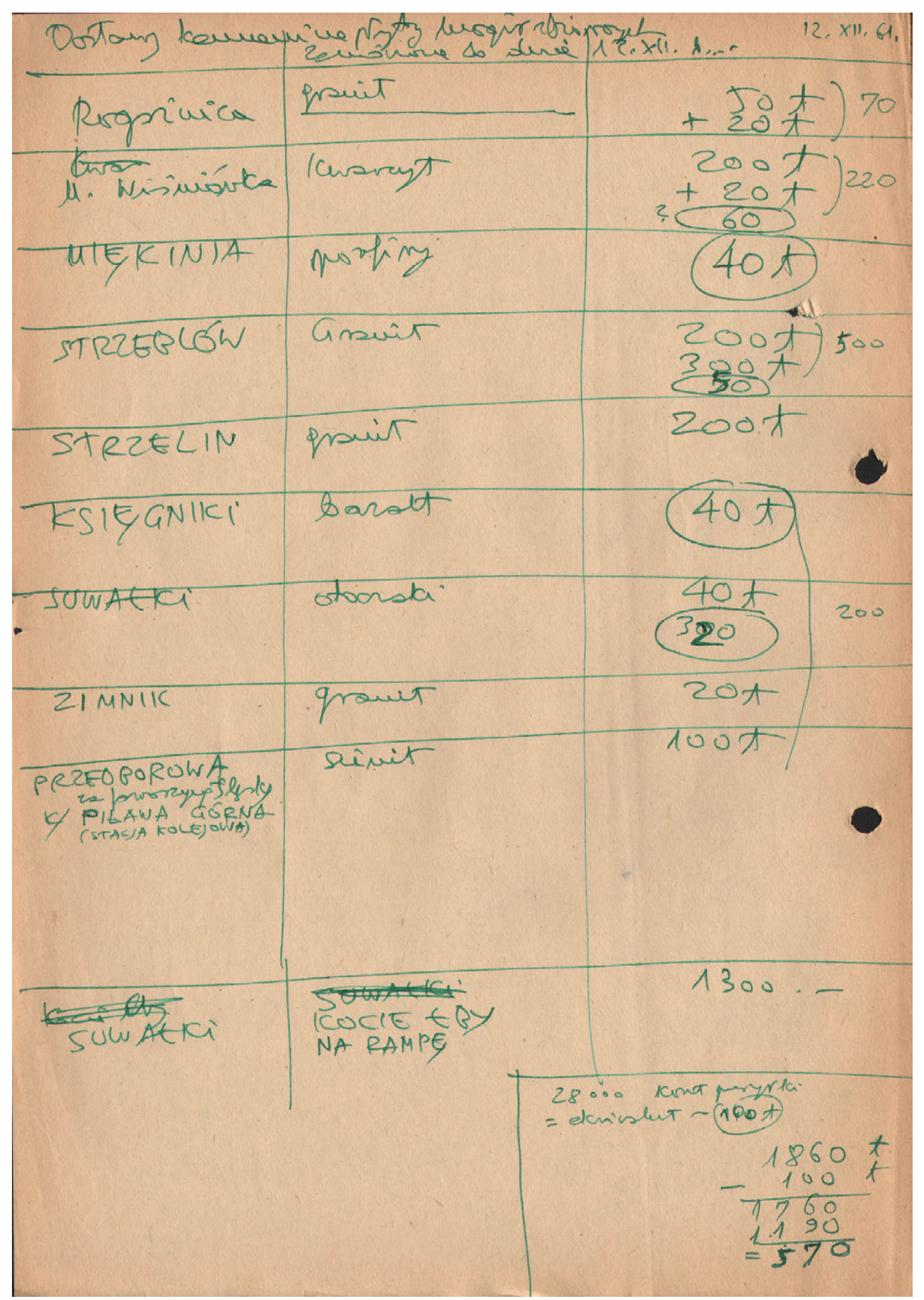

Dostawy kamieni na płyty mogik zbiorowych - zestawienie odręczne autorstwa Adama Haupta datowane na 12 grudnia 1961 roku (dokument z archiwum Adama Haupta, cyt. za: Radecka, 2011) 


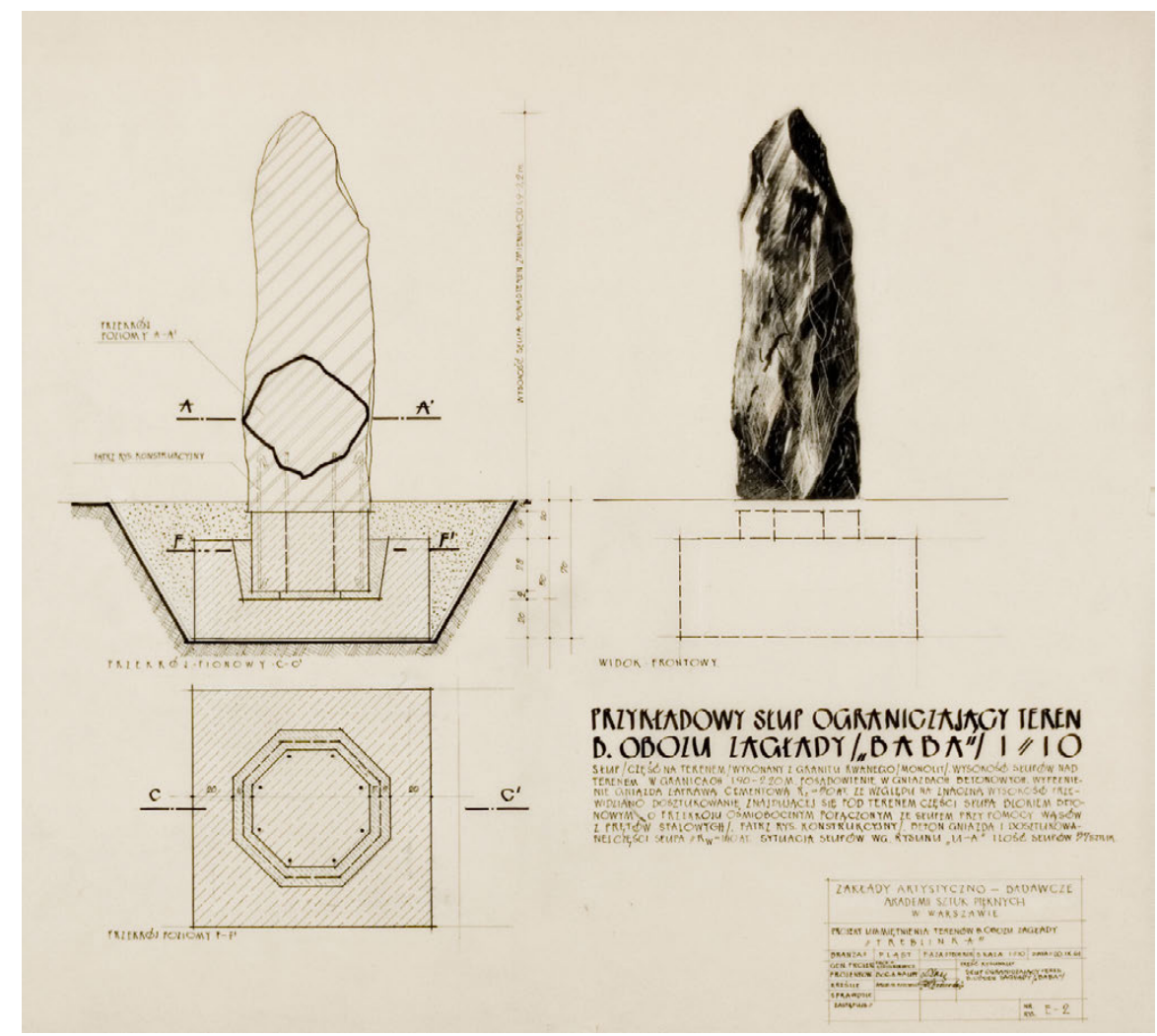

Przykładowy słup ograniczajacy teren b. obozu zagłady (,baba”). Metryka dokumentu głosi: „Zakłady Artystyczno-Badawcze Akademii Sztuk Pięknych w Warszawie. Projekt upamiętnienia terenów b. obozu zagłady «Treblinka». Gen. proj. Franciszek Strynkiewicz. Projektow. Adam Haupt. Kreślił Henryk Kitowski. 20 września 1961” (dokument z archiwum Adama Haupta, cyt. za: Radecka, 2011)

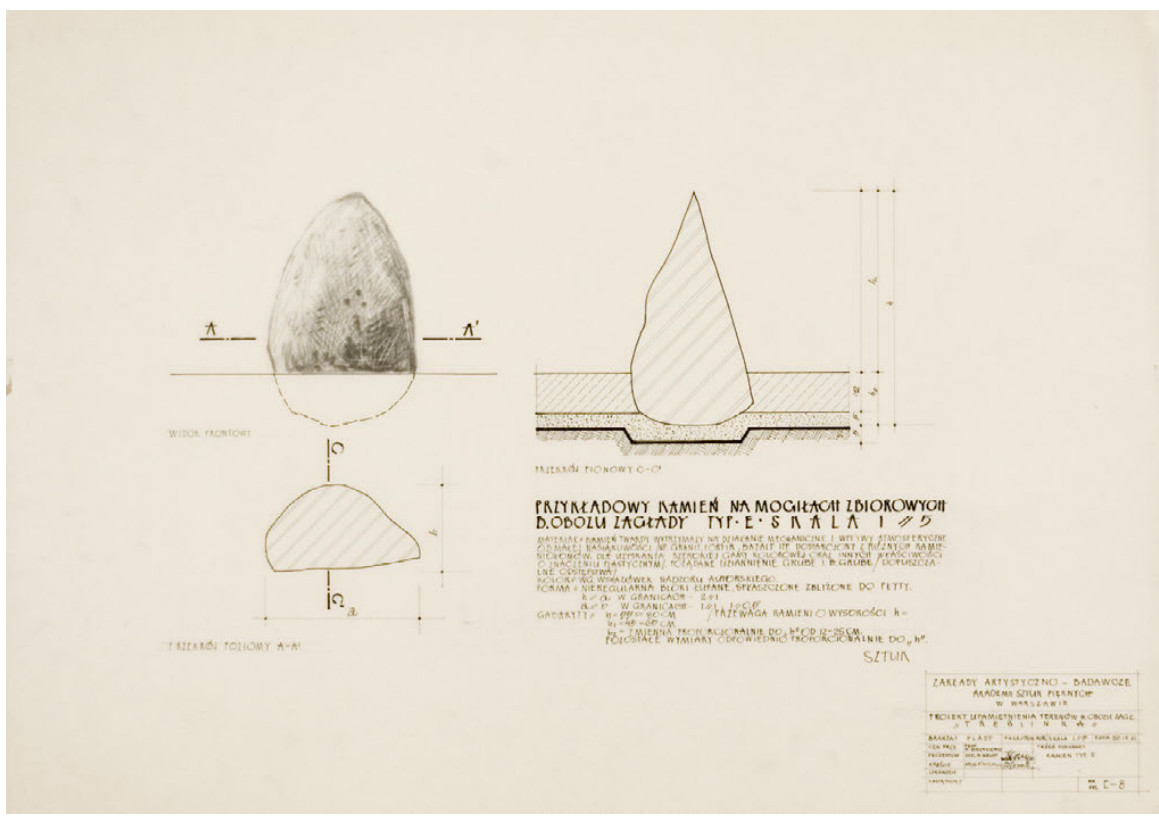

Przykładowy kamień na mogiłach zbiorowych b. obozu zagłady. Typ E. Metryka dokumentu głosi: „Zakłady Artystyczno-Badawcze Akademii Sztuk Pięknych w Warszawie. Projekt upamiętnienia terenów b. obozu zagłady «Treblinka». Gen. proj. Franciszek Strynkiewicz. Projektow. Adam Haupt. Kreślił Henryk Kitowski. 20 września 1961" (dokument z archiwum Adama Haupta, cyt. za: Radecka, 2011) 


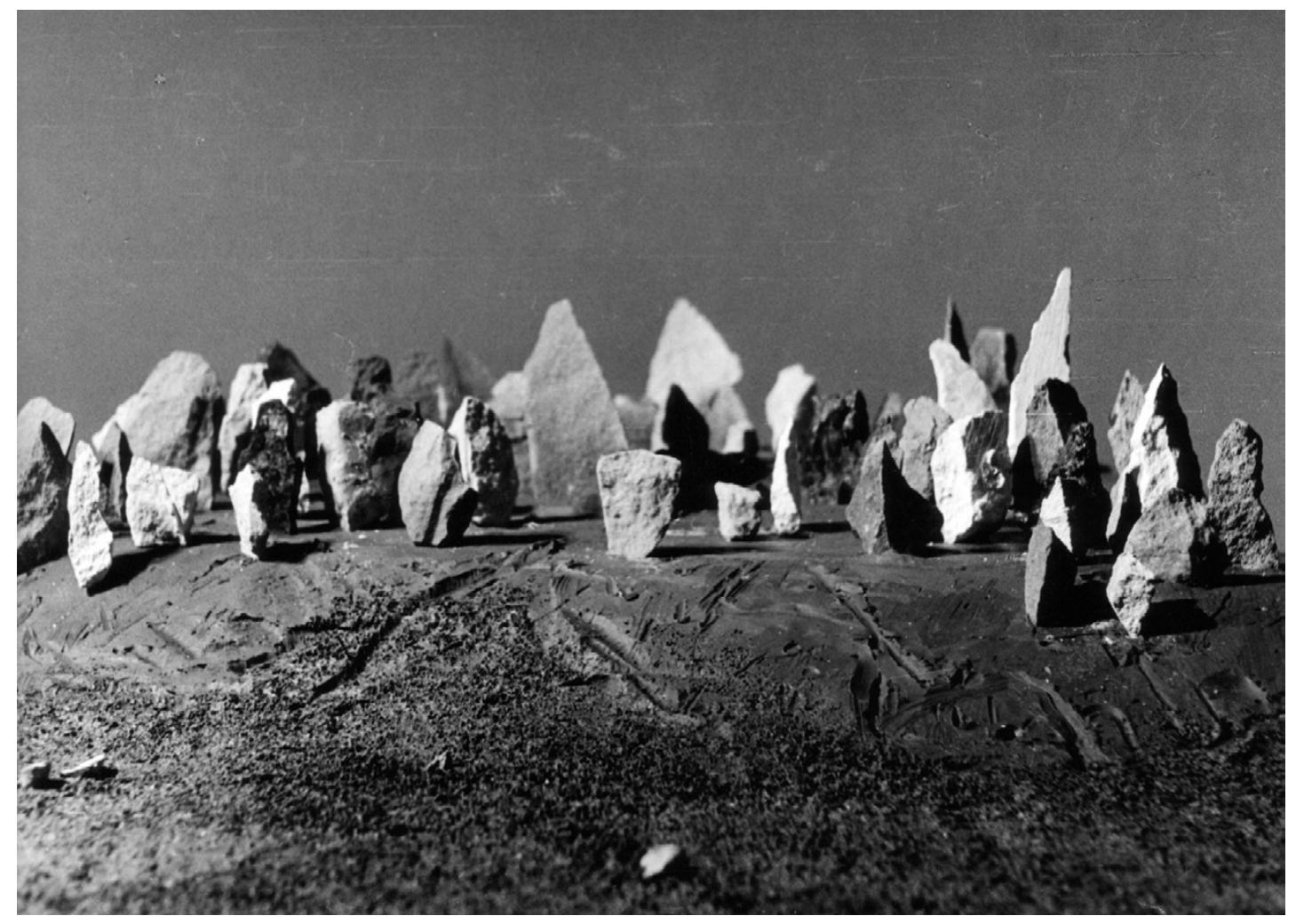

Sporządzona przez Adama Haupta makieta rozmieszczenia kamieni sfotografowana prawdopodobnie przez Adama Haupta w 1960 roku (fotografia z archiwum Adama Haupta, cyt. za: Radecka, 2011)

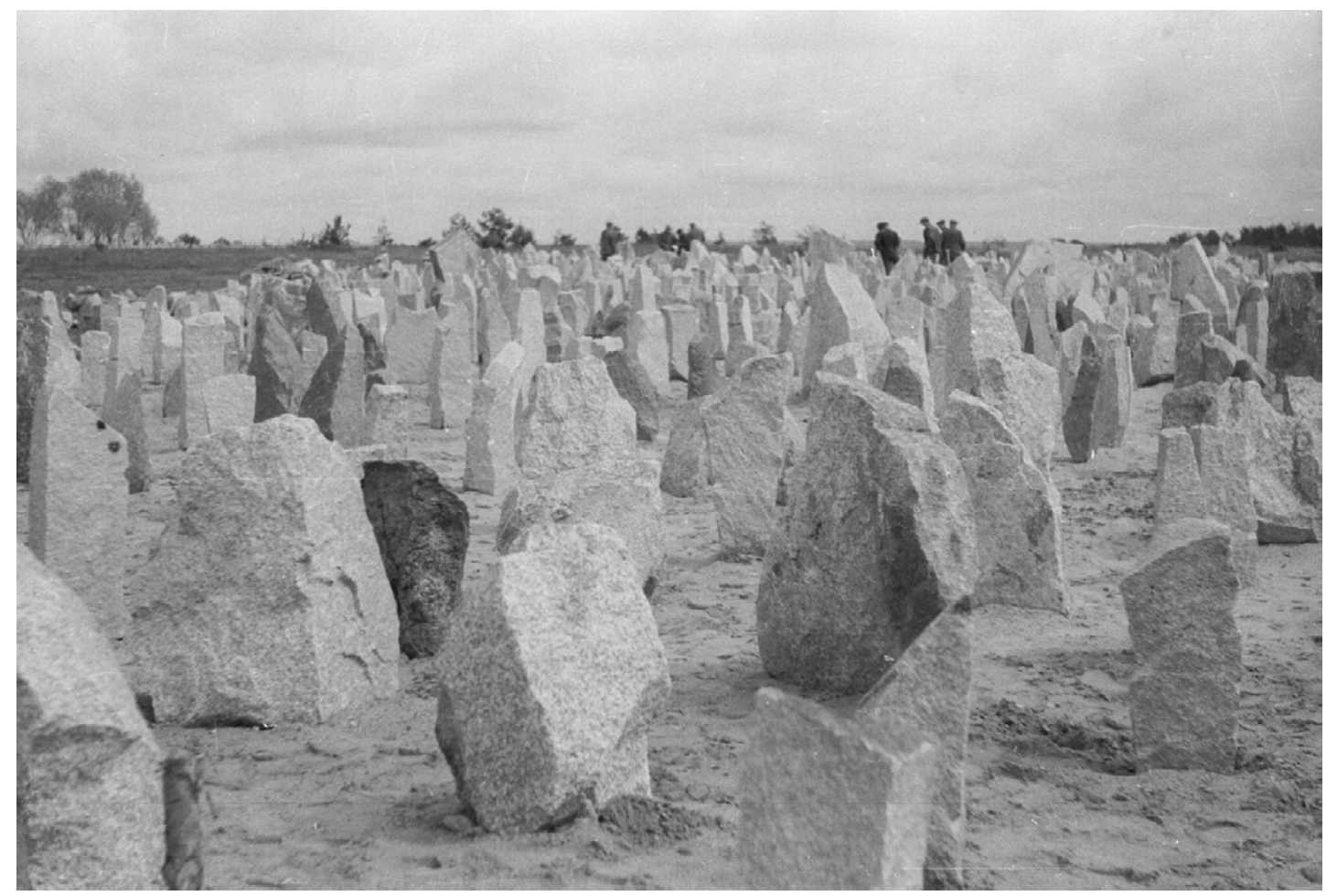

Skupisko prochów i innych szczątków w południowej części strefy śmierci (Totenlager) sfotografowane w 1963 roku prawdopodobnie przez Adama Haupta. Rozdysponowane kamienie przed wylaniem betonu. W tle widoczne otaczające wierzby skupisko III (fotografia z archiwum Adama Haupta, cyt. za: Radecka, 2011) 


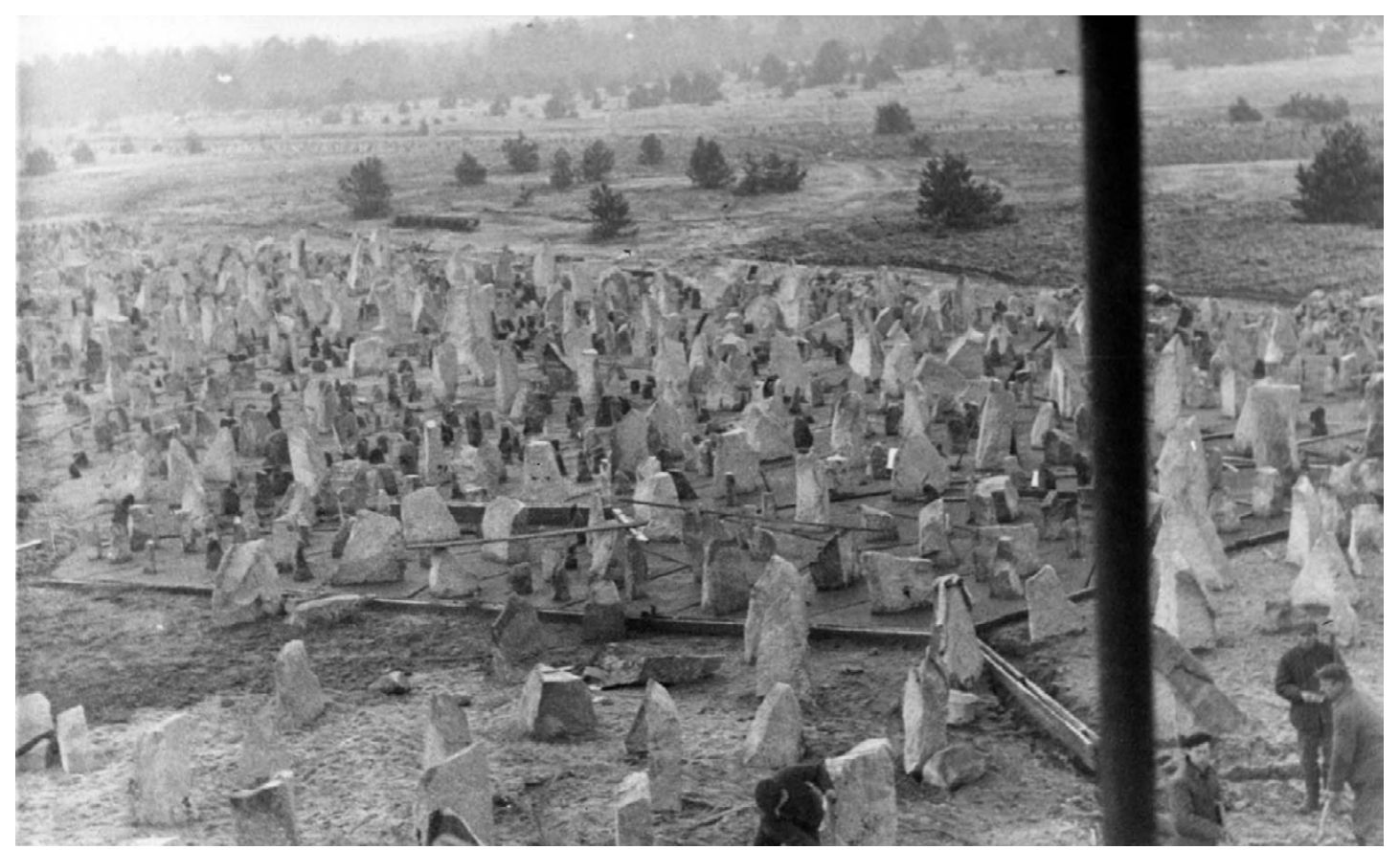

Kolejne stadia robót sfotografowane w 1963 roku prawdopodobnie przez Adama Haupta. Na drugim planie widać gotową betonową płytę. Na pierwszym planie beton zostanie dopiero wylany (fotografia z archiwum Adama Haupta, cyt. za: Radecka, 2011)

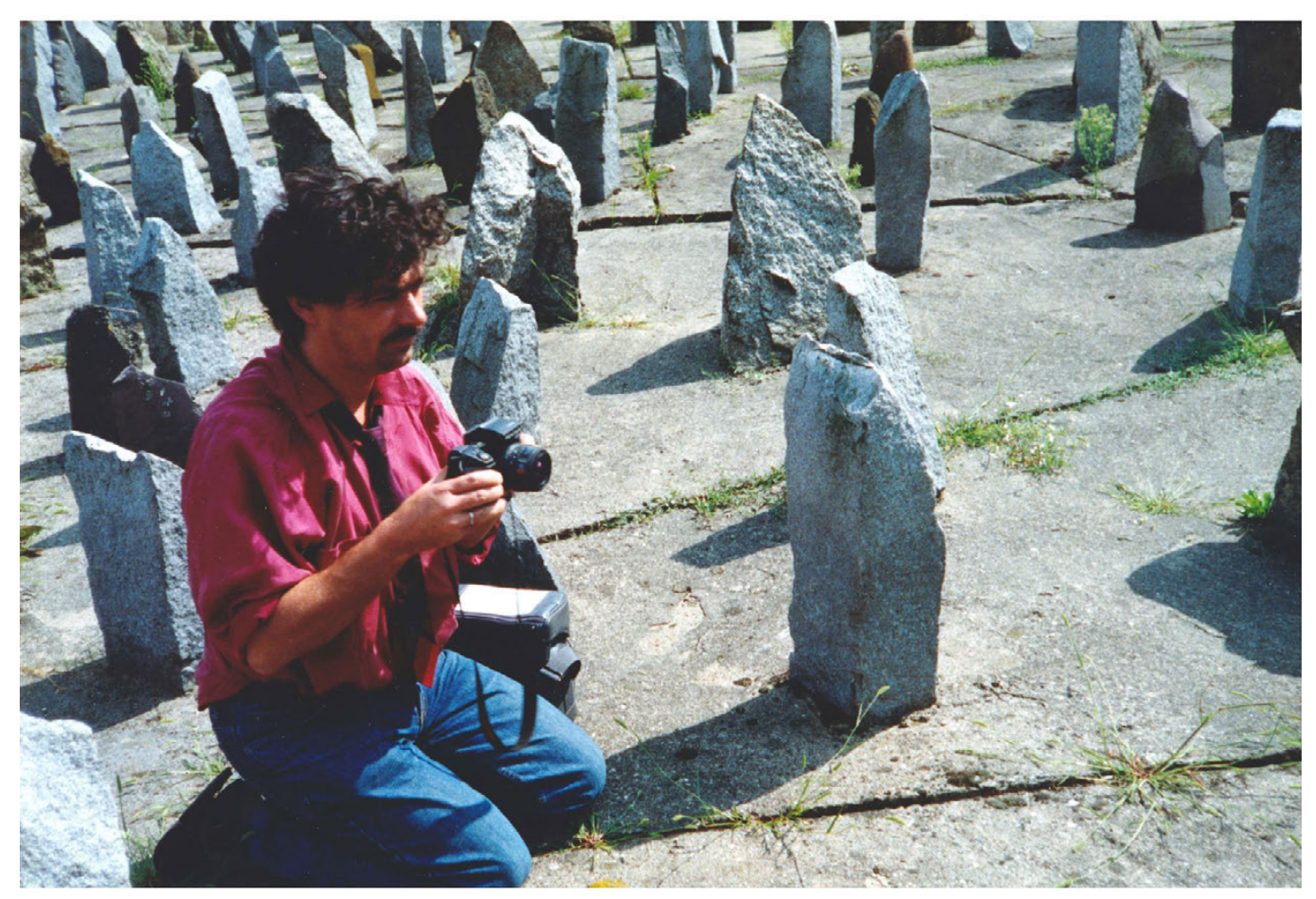

Krzysztof Jung - Treblinka II, 16 sierpnia 1991 (fot. Wojciech Karpiński) (@ by Wojciech Karpiński, dzięki uprzejmości Autora zdjęcia). Specjalne podziękowania dla Doroty Krawczyk-Janisch 


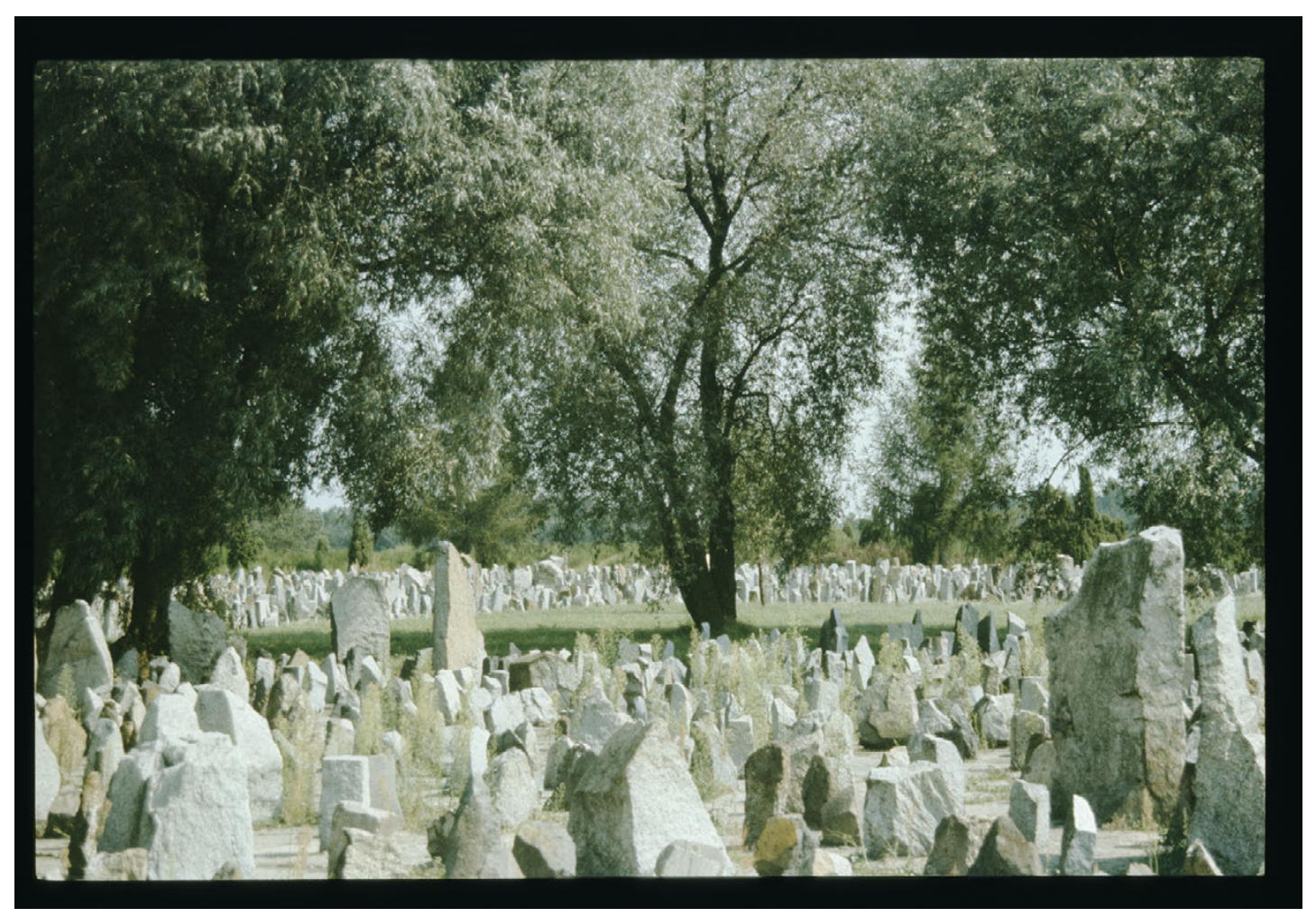

Wierzby Treblinki II w dniu 16 sierpnia 1991. Widok w kierunku wschodnim (fot. Krzysztof Jung) (๔ by Dorota Krawczyk-Janisch i Wojciech Karpiński, dzięki uprzejmości Obydwojga)

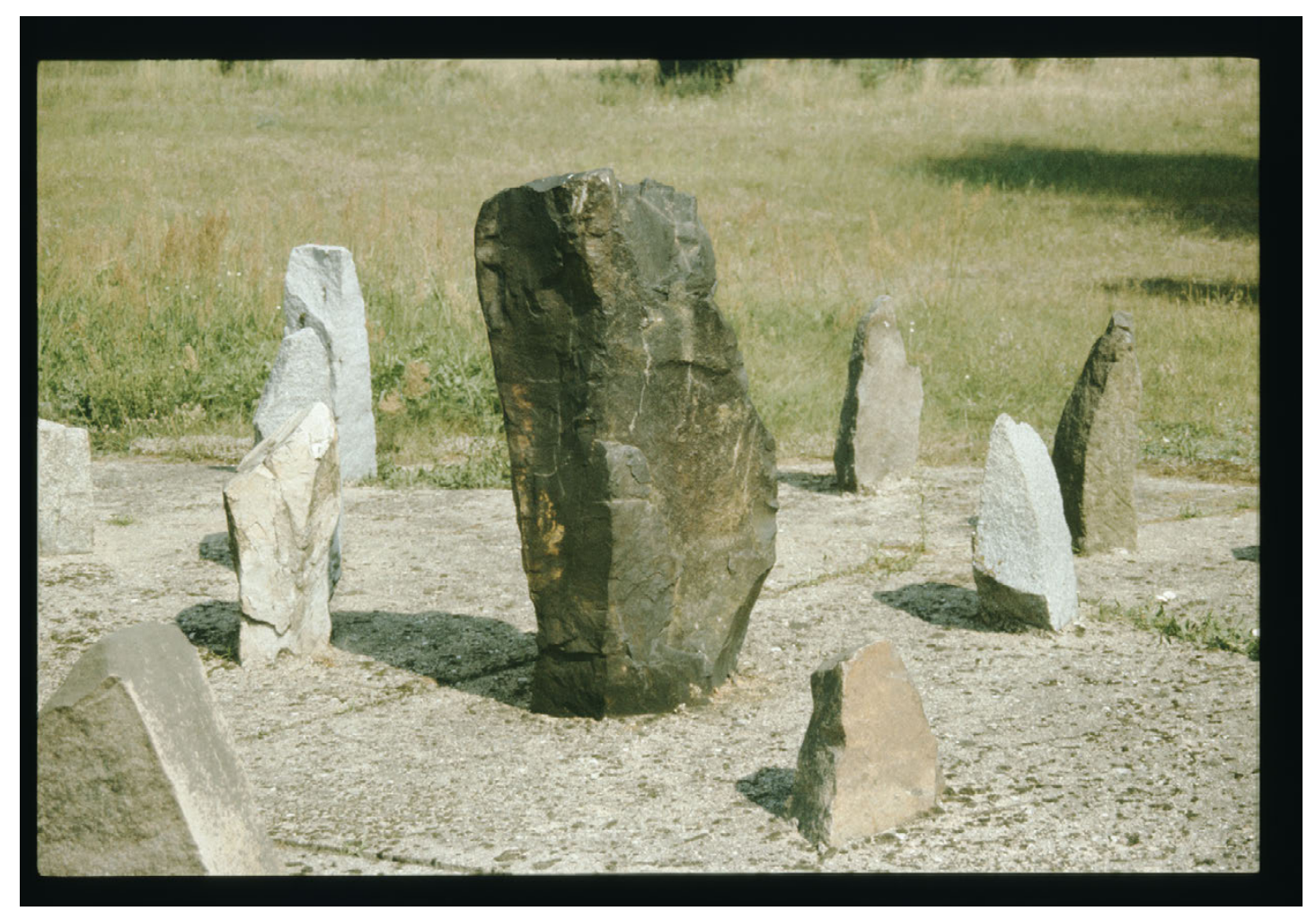

Kamienie z przykrywy mogił II spomiędzy byłego „Lazaretu” a lokalizacji komór gazowych, w połowie długości południowej krawędzi obozu - Treblinka II, 16 sierpnia 1991 (fot. Krzysztof Jung) (๔ by Dorota Krawczyk-Janisch i Wojciech Karpiński, dzięki uprzejmości Obydwojga) 


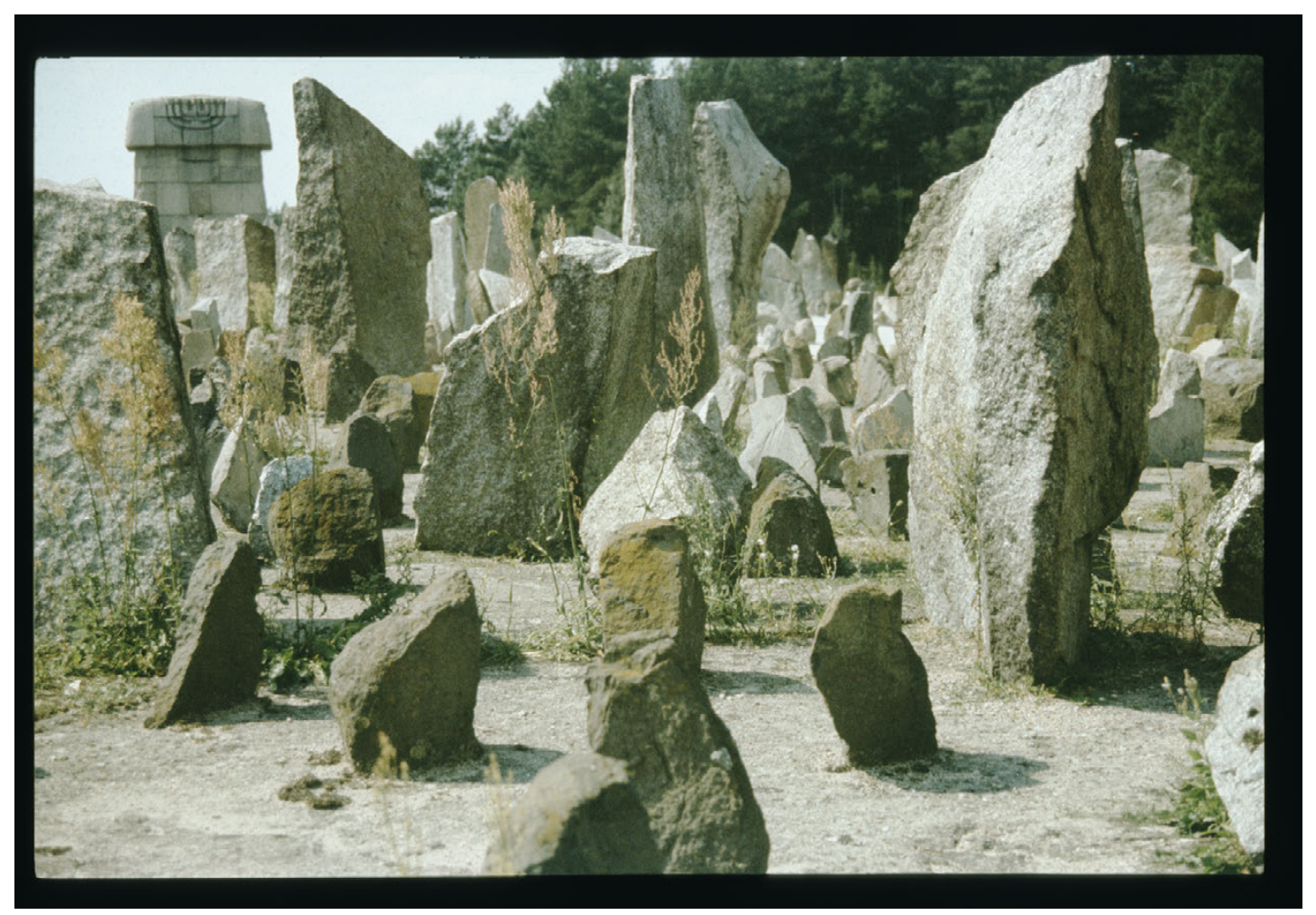

Rumex acetosella, czyli szczaw polny - Treblinka II, 16 sierpnia 1991 (fot. Krzysztof Jung) (๔ by Dorota Krawczyk-Janisch i Wojciech Karpiński, dzięki uprzejmości Obydwojga)

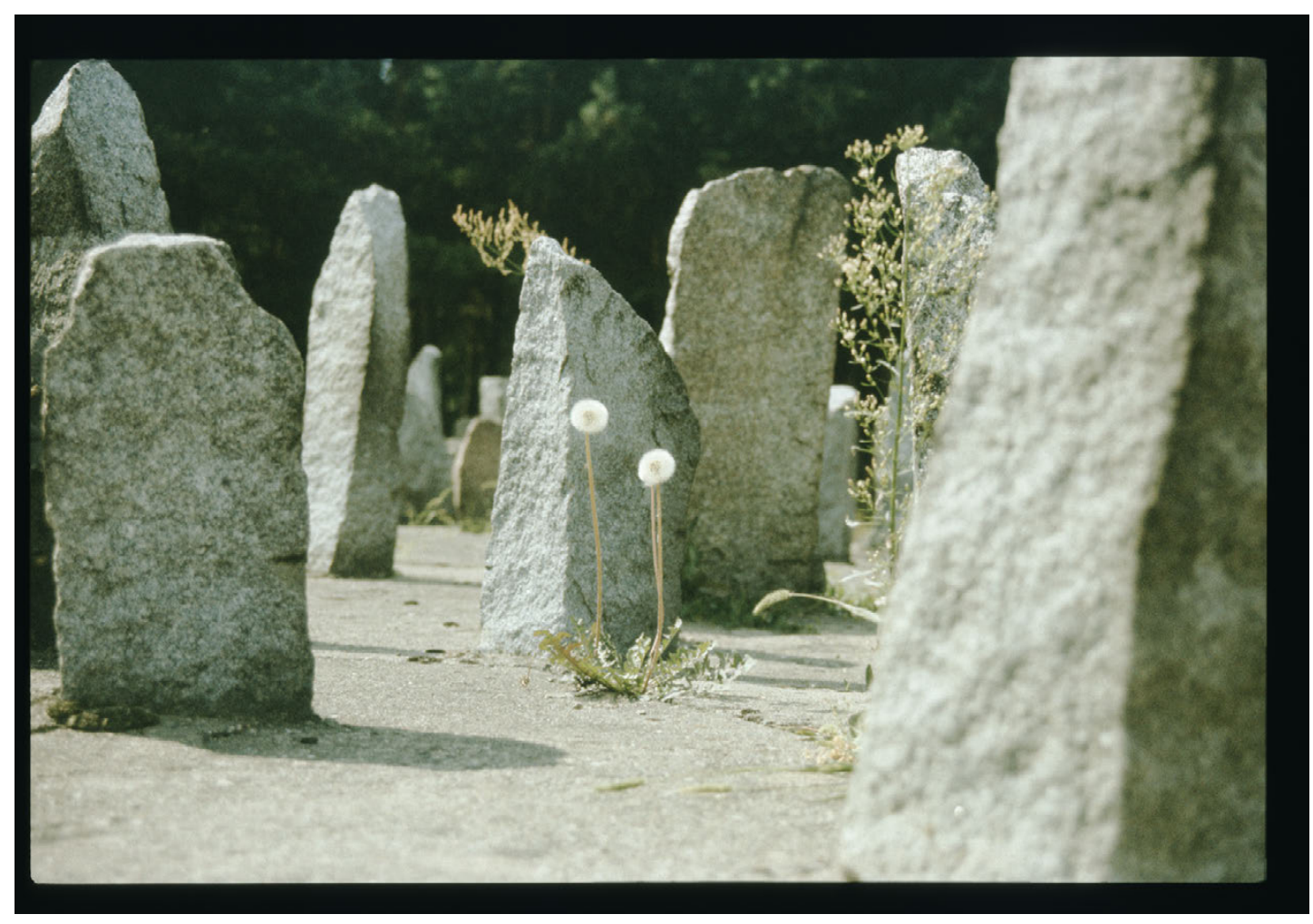

Taraxacum officinale, czyli mniszek lekarski - Treblinka II, 16 sierpnia 1991 (fot. Krzysztof Jung) (๔ by Dorota Krawczyk-Janisch i Wojciech Karpiński, dzięki uprzejmości Obydwojga) 


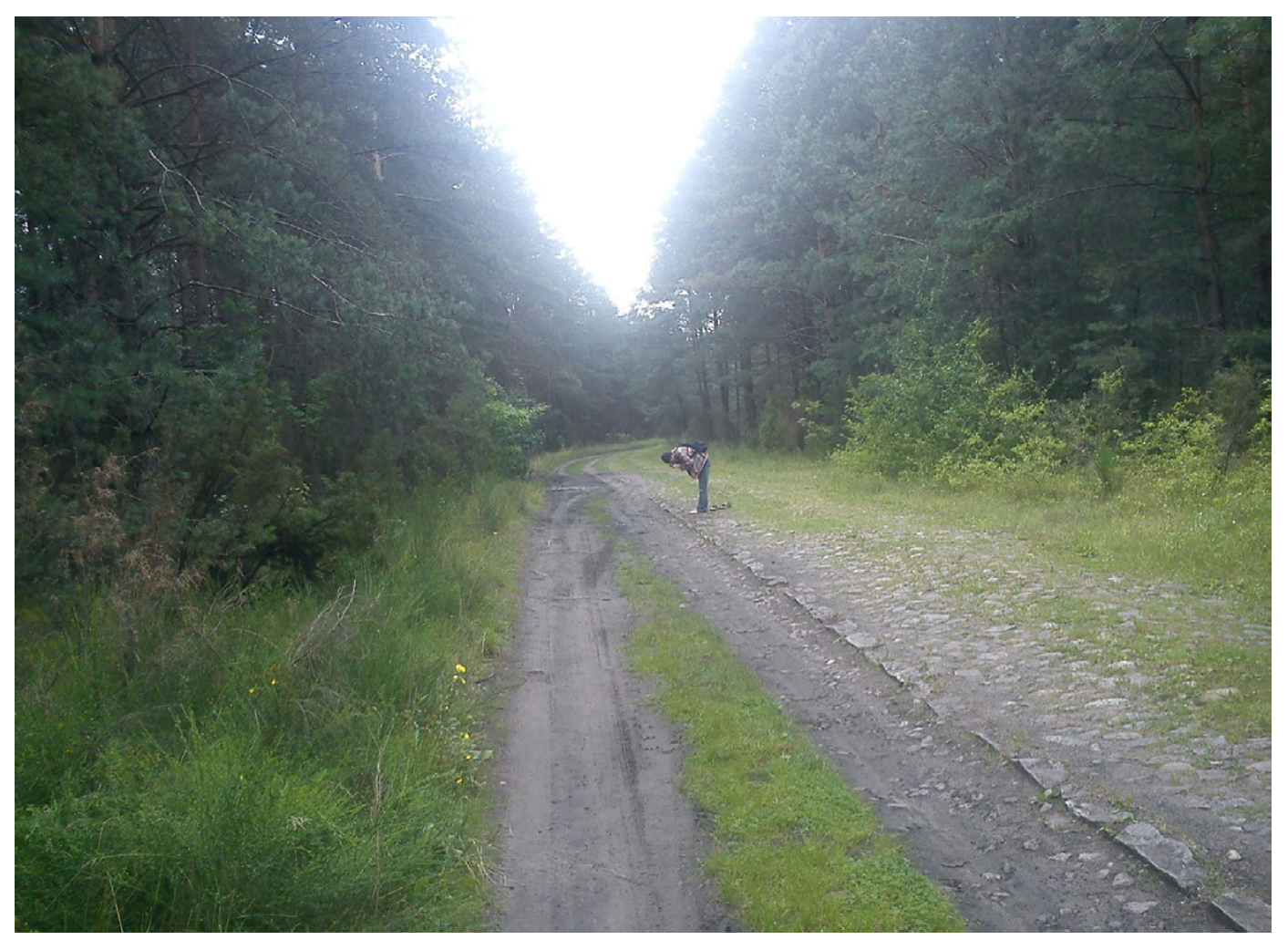

Arie (1) - Czarna Droga, 14 sierpnia 2011 (fot. Henryk Hollender) (๔ by Henryk Hollender, dzięki uprzejmości Autora zdjęcia)

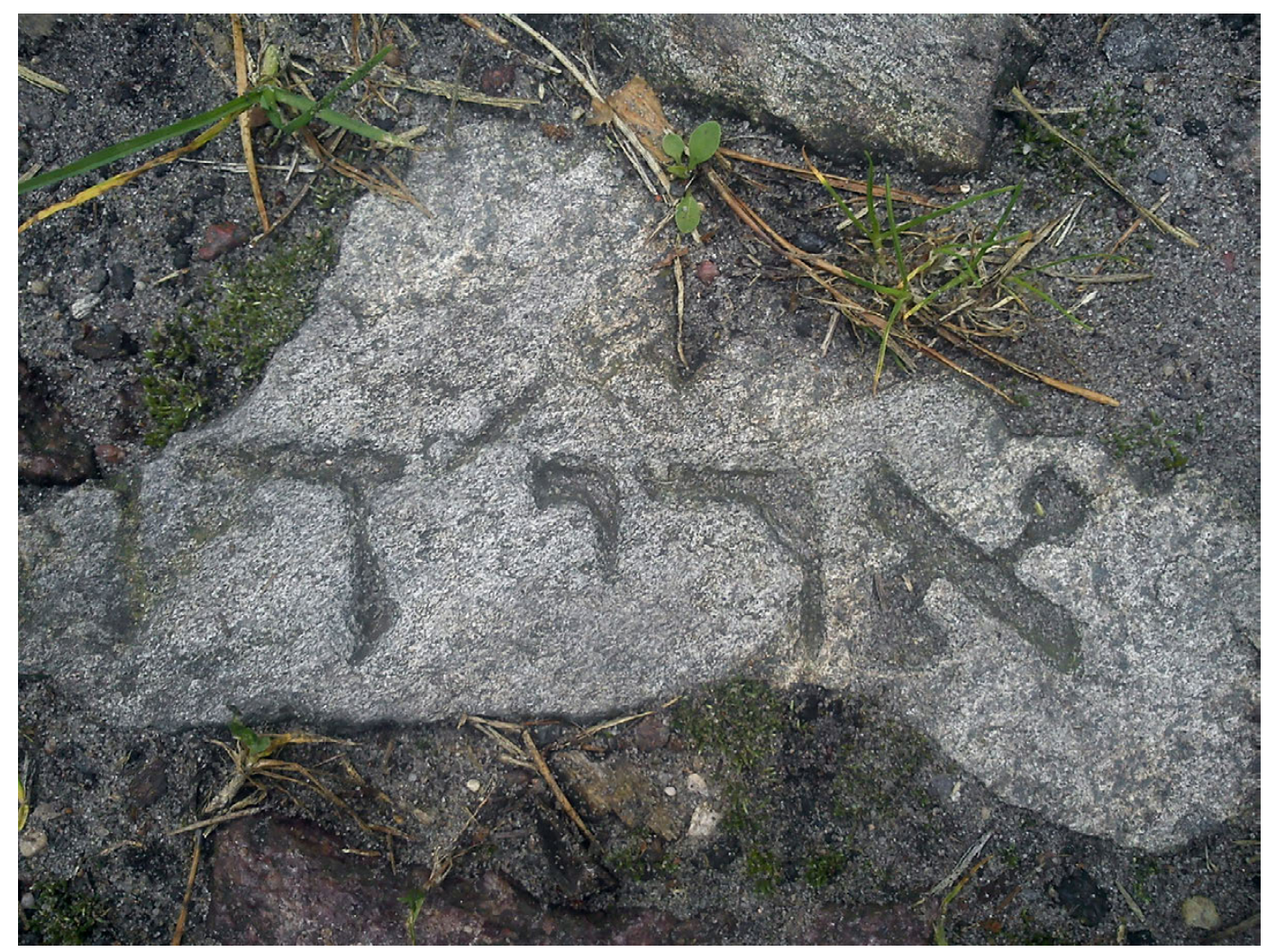

Arie (2) - Czarna Droga, 14 sierpnia 2011 (fot. Henryk Hollender) (๔ by Henryk Hollender, dzięki uprzejmości Autora zdjęcia) 


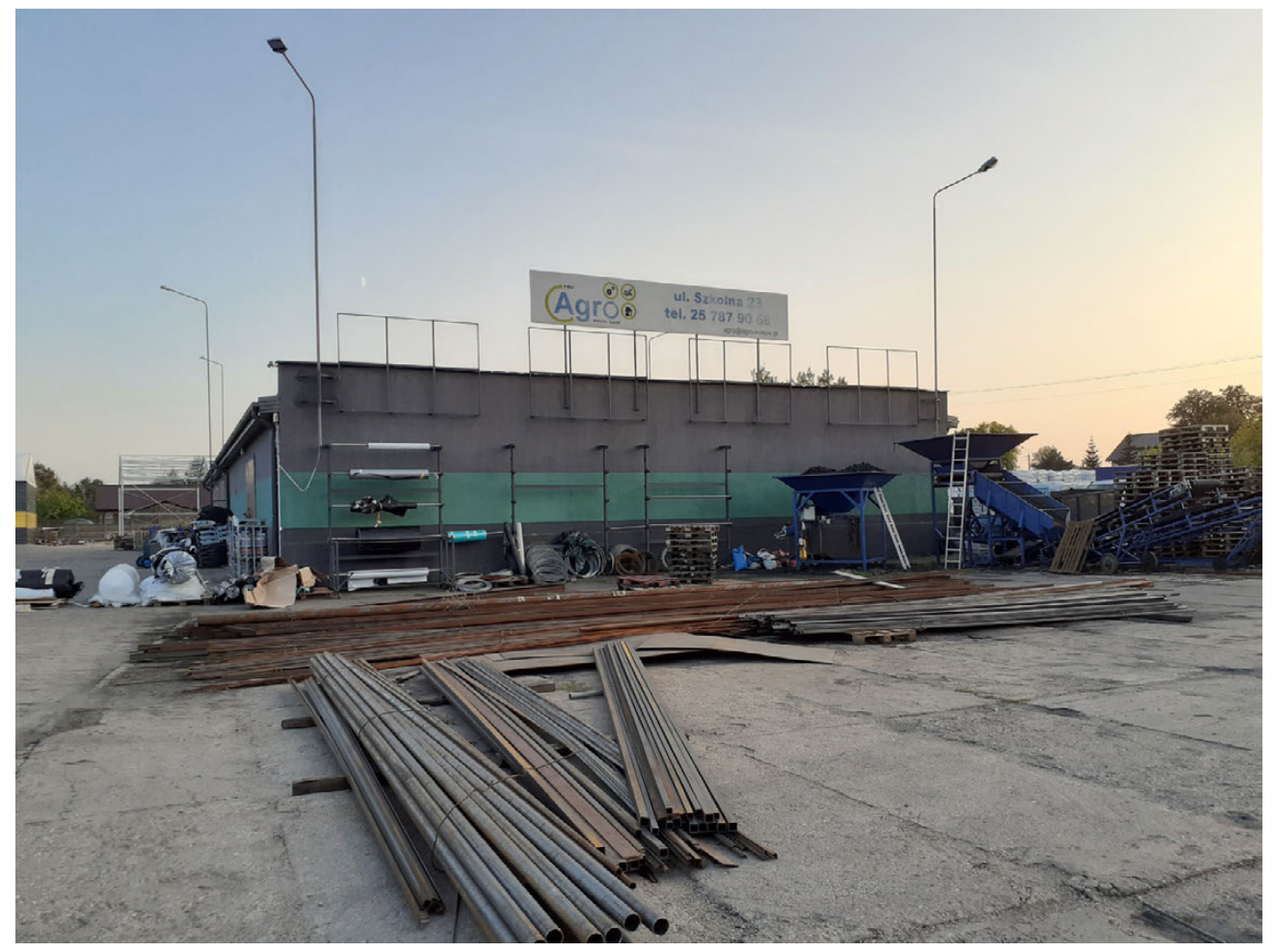

Stary cmentarz żydowski, część frontowa. Obrabowany z macew z rozkazu Niemców w czasie wojny, po wojnie zamieniony przez Polaków w Gminną Spółdzielnię (GS) z piekarnią i rozlewnią piwa, obecnie w rękach prywatnych - Kosów Lacki, ulica Szkolna 23, 23 września 2020 (fot. Elżbieta Janicka). Specjalne podziękowania dla Marii Cyranowicz i Zbigniewa Chłusa za walną pomoc w realizacji materiału na terenie starego cmentarza

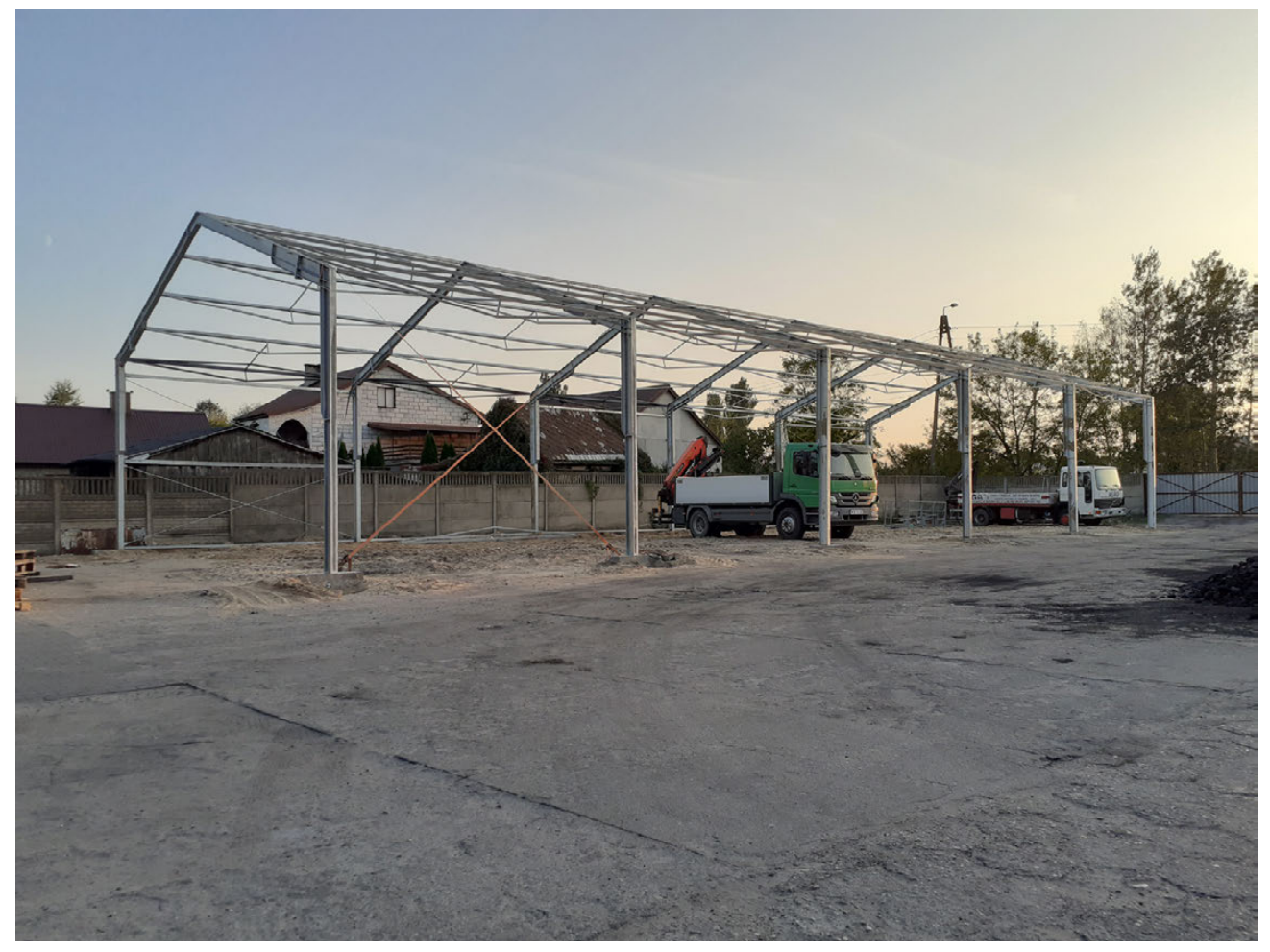

Stary cmentarz żydowski, część tylna. Z prawej strony kadru tylne wejście od ulicy Towarowej, graniczącej z cmentarzem od zachodu - Kosów Lacki, ulica Szkolna 23, 23 września 2020 (fot. Elżbieta Janicka) 


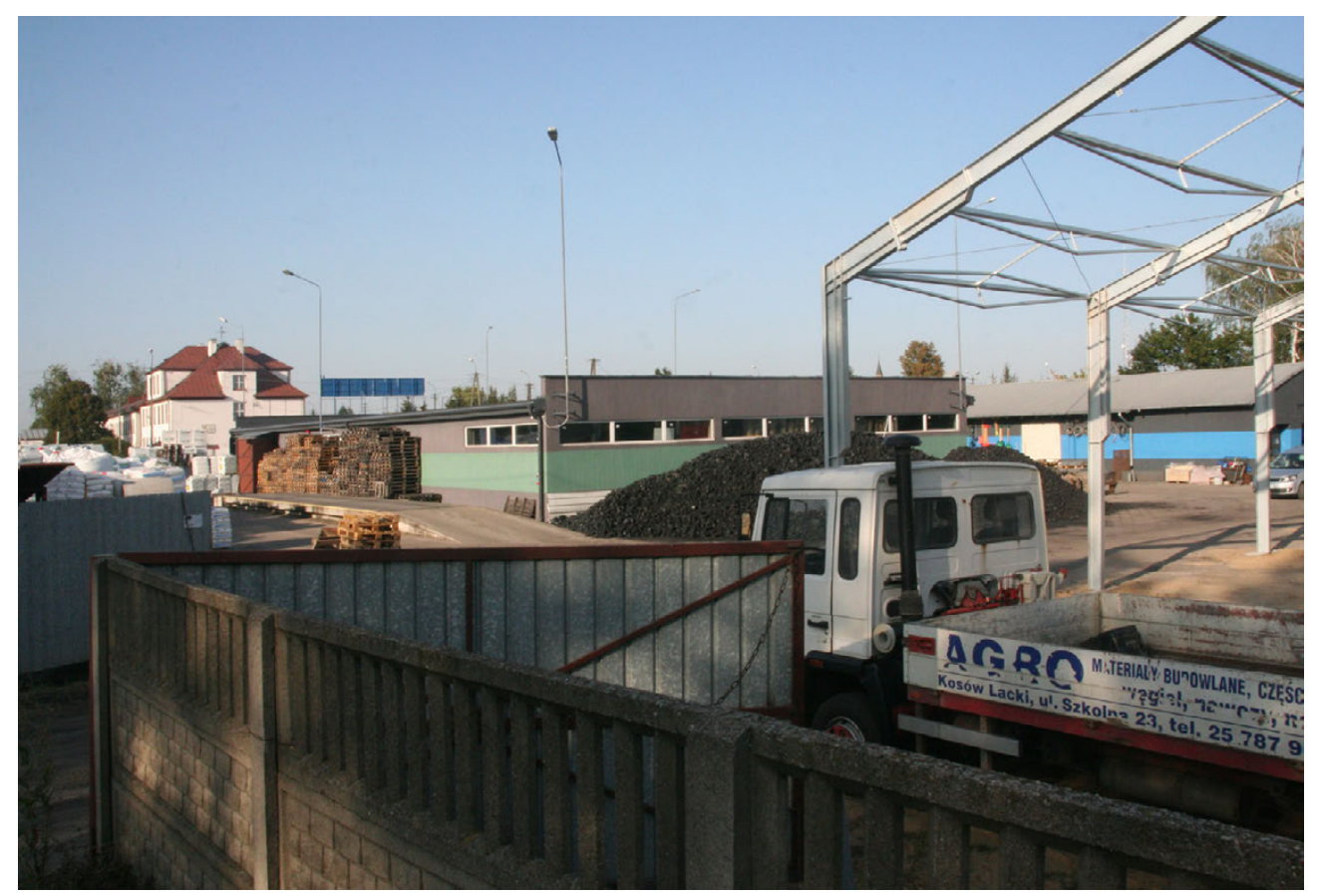

Stary cmentarz żydowski. Widok zza tylnego wejścia od ulicy Towarowej. Biały budynek po drugiej stronie ulicy Szkolnej to przedwojenna szkoła, dziś szkoła podstawowa im. Stefana Kardynała Wyszyńskiego. Na frontowej, południowej ścianie budynku widoczna tablica z nazwą placówki. Z prawej strony białego przęsła najbliżej centrum obrazu widoczna wieża kościoła rzymskokatolickiego pod wezwaniem Narodzenia Najświętszej Maryi Panny - Kosów Lacki, ulica Szkolna 23, 23 września 2020 (fot. Elżbieta Janicka)

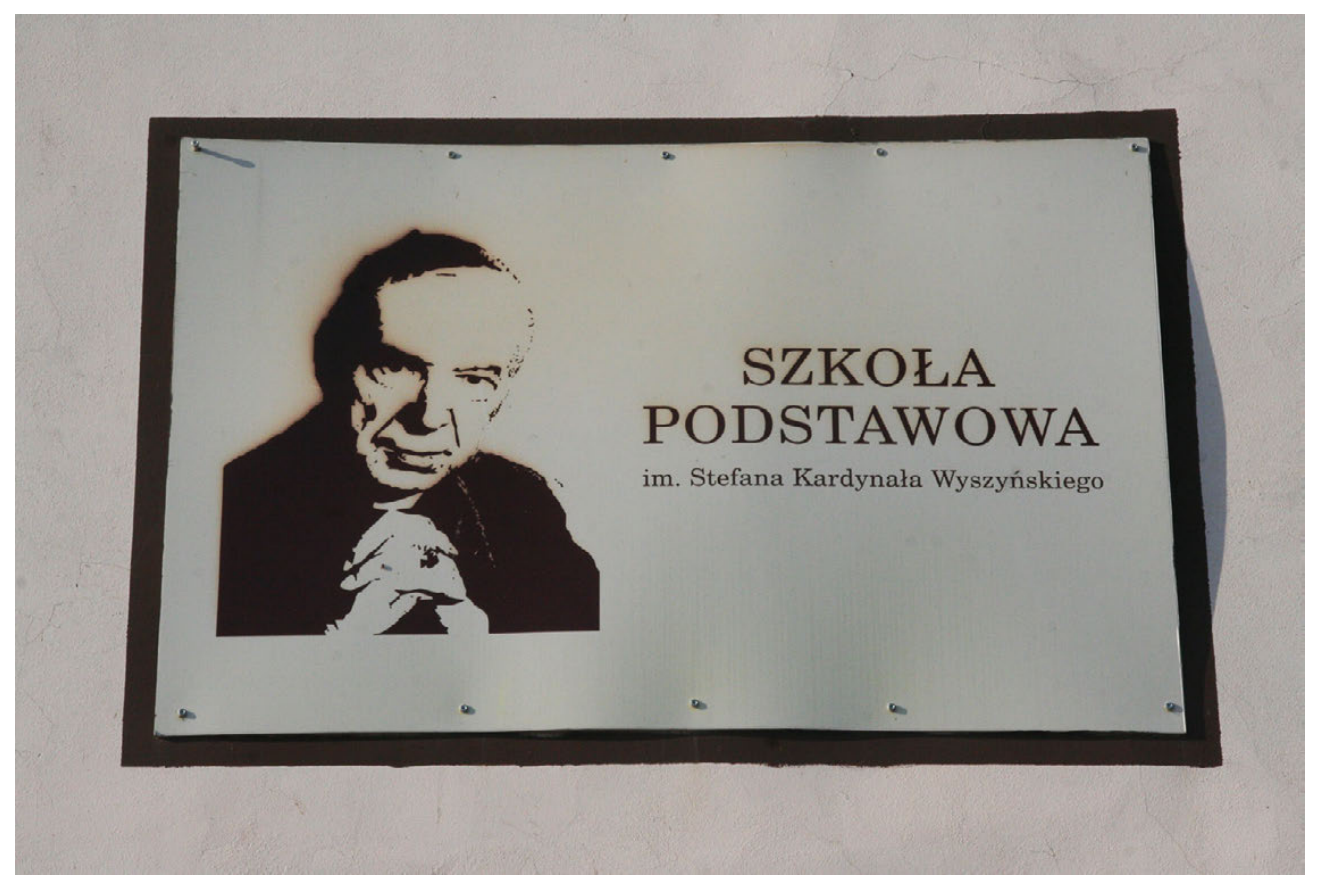

Tablica z nazwą na południowej, frontowej ścianie budynku szkoły naprzeciwko starego cmentarza żydowskiego. Urodzony w pobliskiej Zuzeli, a zatem również w okolicy Treblinki, Stefan Wyszyński, był powojennym liderem Kościoła rzymskokatolickiego w Polsce. W okresie powojennych pogromów na Żydach odmówił ogłoszenia, że chrześcijańska legenda o żydowskim mordzie rytualnym jest kłamstwem. Następnie zaś zachował milczenie podczas kolejnych antysemickich nagonek oraz rasowego „czyszczenia” kraju w latach czterdziestych, pięćdziesiątych i sześćdziesiątych - Kosów Lacki, ulica Polna 1, 23 września 2020 (fot. Elżbieta Janicka) 


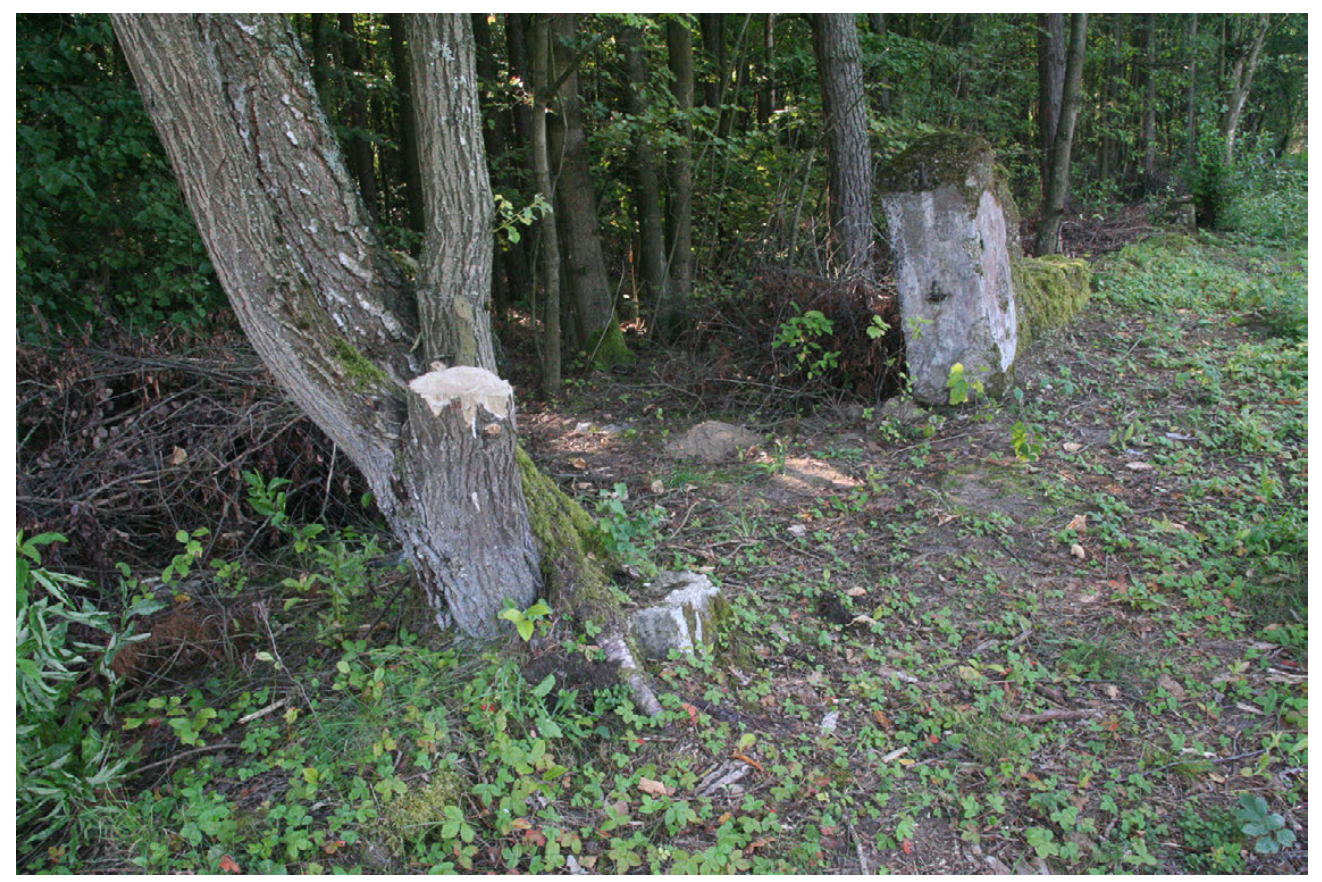

Brama nowego cmentarza żydowskiego. Obrabowany z macew z rozkazu Niemców w czasie wojny, po czym spontanicznie, oddolnie przekopany i po wojnie „zalesiony w czynie społecznym” przez Polaków. Brama cmentarza to jedyne, co pozostało z jego północnego muru od strony miasteczka - południowe peryferie Kosowa Lackiego przy starej drodze na Sokołów Podlaski (za rondem, obok stacji benzynowej zwanej przez mieszkańców miasteczka CPN-em, mimo iż państwowa Centrala Produktów Naftowych przestała istnieć w 1994 roku), 12 września 2020 (fot. Elżbieta Janicka). Specjalne podziękowania dla Henryka Hollendra za walną pomoc w realizacji materiału na terenie nowego cmentarza latem

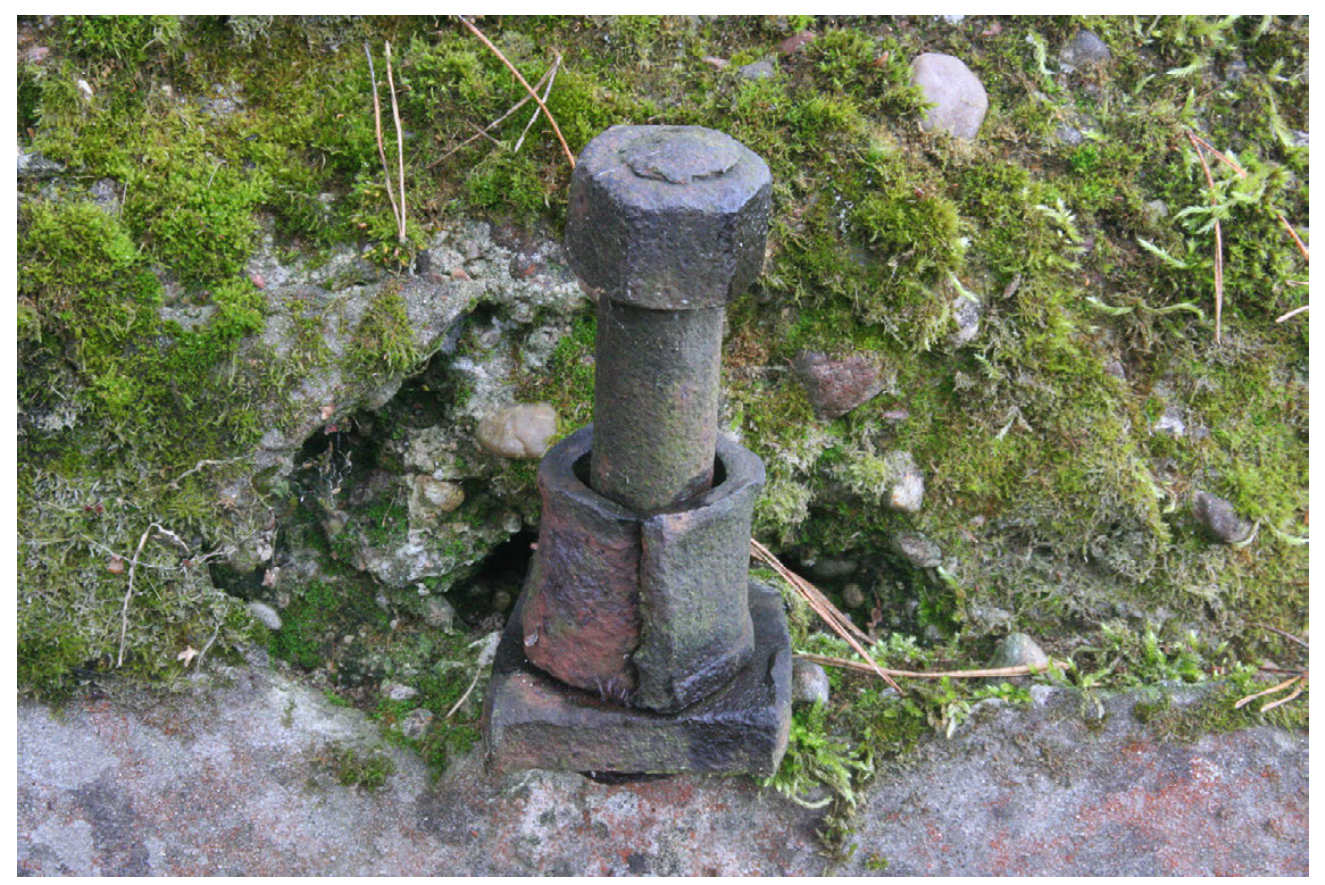

Jeden z trzech zachowanych zawiasów w jedynym zachowanym (prawym) filarze bramy nowego cmentarza. Brama usytuowana jest nieopodal północno-wschodniego narożnika terenu nekropolii - południowe peryferie Kosowa Lackiego przy starej drodze na Sokołów Podlaski (za rondem „przy CPN-ie"), 28 listopada 2020 (fot. Elżbieta Janicka). Specjalne podziękowania dla Henryka Hollendra i Ewy Lewandowskiej za pomoc w realizacji materiału na terenie nowego cmentarza jesienią 


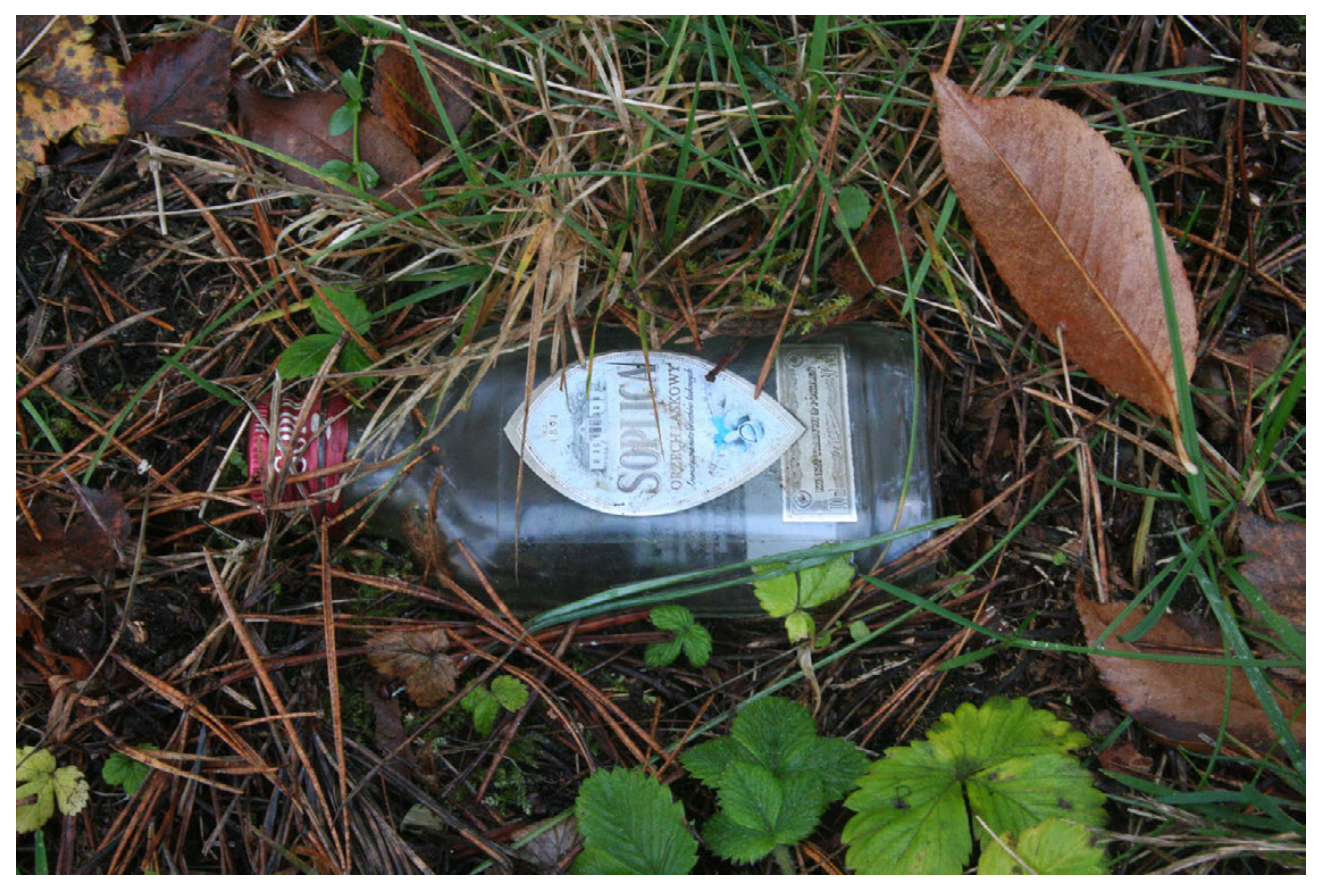

„Soplica (aromatyczna nuta orzechów laskowych). Kunszt tradycji od pokoleń”. Rodzina Sopliców, właściciele niewolników, wraz ze swoim dworem w Soplicowie - jak wyobraził ich Adam Mickiewicz w Panu Tadeuszu (1834), uchodzącym za „epopeję narodową” - to emblematy tak zwanej prawdziwej polskości - nowy cmentarz żydowski, południowe peryferie Kosowa Lackiego przy starej drodze na Sokołów Podlaski (za rondem „przy CPN-ie”), 28 listopada 2020 (fot. Elżbieta Janicka)

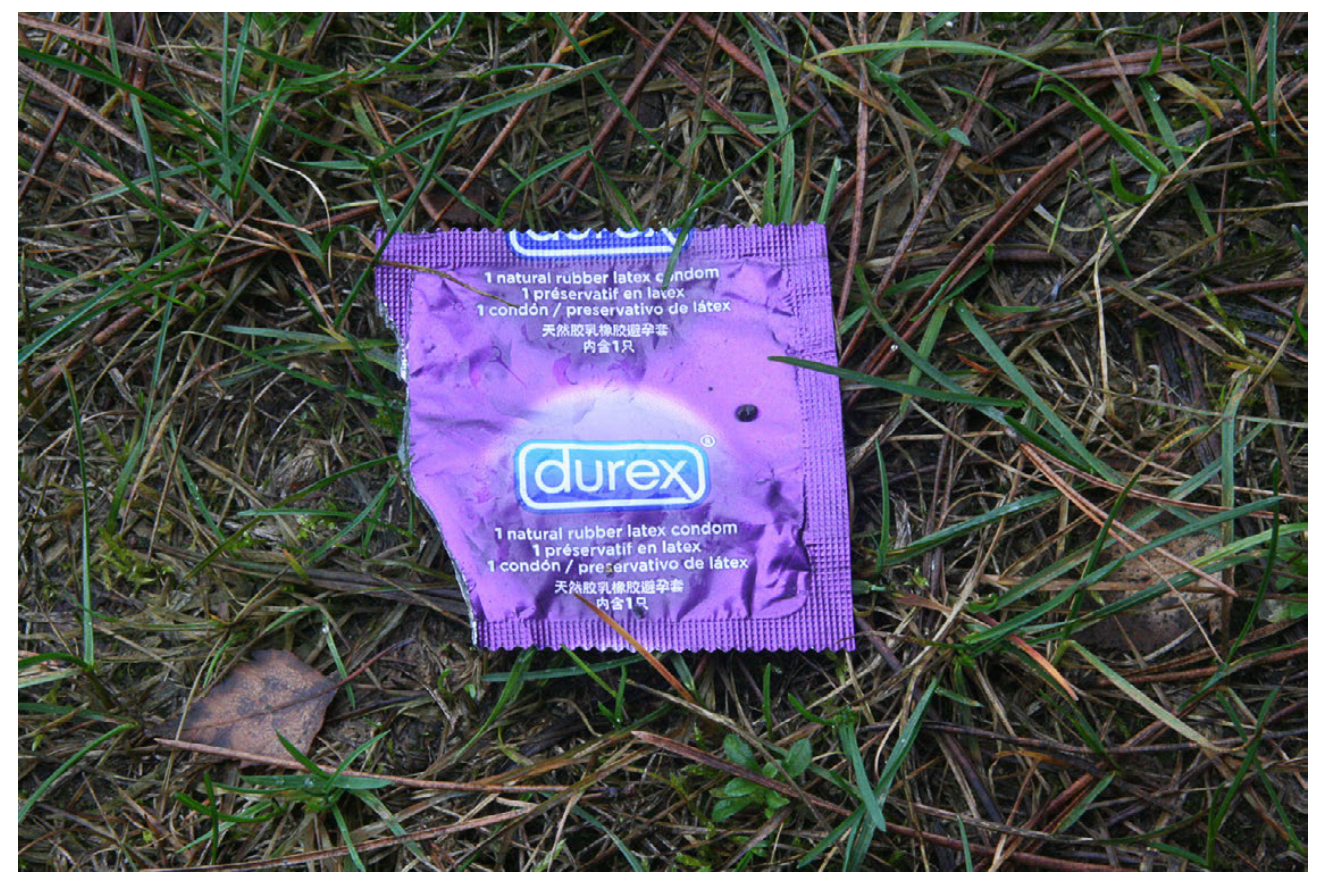

„Durex. 1 natural rubber latex condom” - nowy cmentarz żydowski, południowe peryferie Kosowa Lackiego przy starej drodze na Sokołów Podlaski (za rondem przy „CPN-ie”), 28 listopada 2020 (fot. Elżbieta Janicka) 


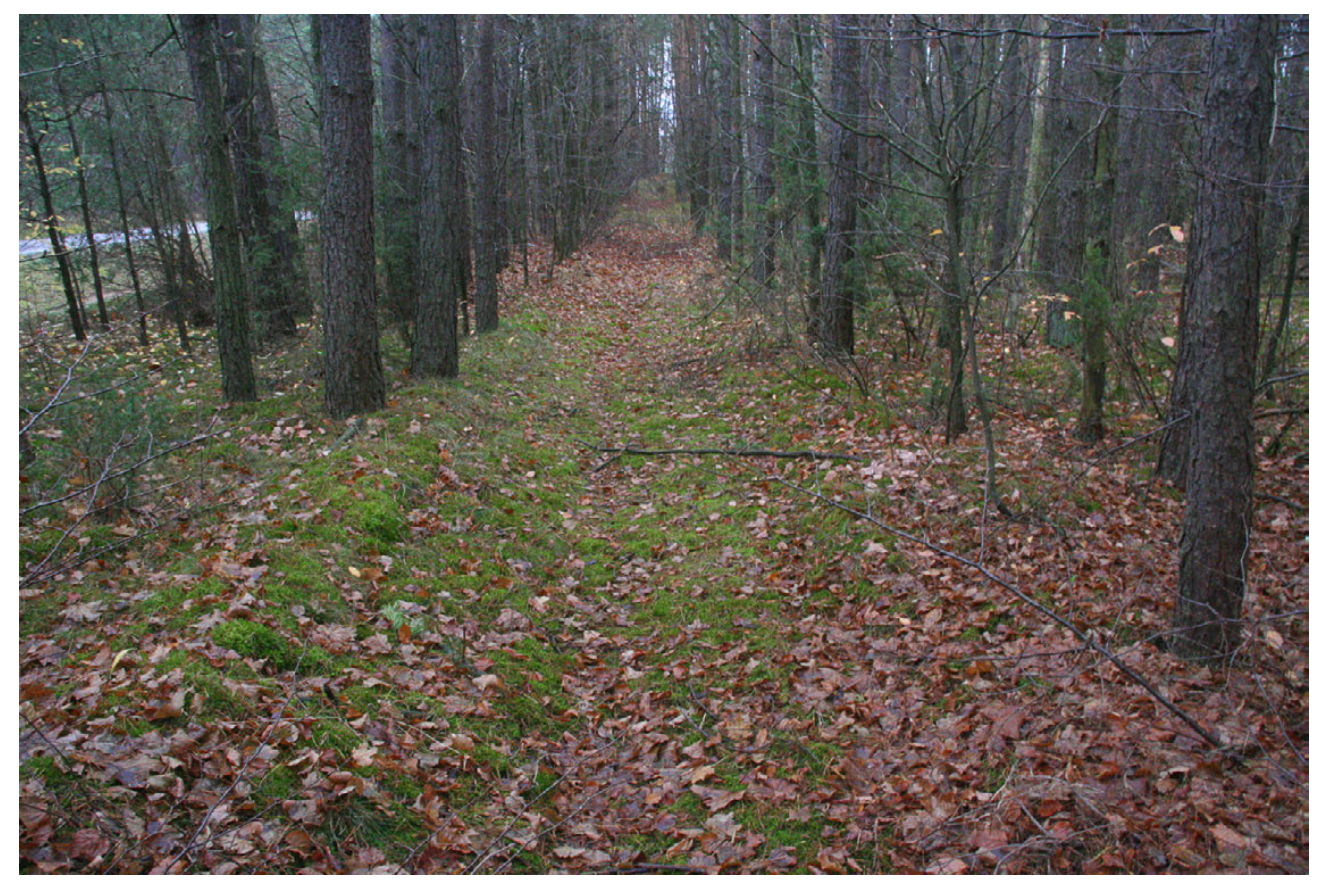

Zachowana lub utworzona przez polskich chrześcijan aleja na osi północ-południe w zachodniej części nowego cmentarza żydowskiego, równoległa do jego zachodniej granicy. Aleja może wskazywać na istnienie drugiej bramy, bliżej północno-zachodniego narożnika cmentarnego terenu. W prześwitach lasu z lewej strony widoczna stara droga na Sokołów Podlaski. Prześwit u szczytu alei wychodzi na rondo „przy CPN-ie”. Zachodnia granica cmentarza biegnie między drogą a aleją. Widok W stronę północną - nowy cmentarz żydowski, południowe peryferie Kosowa Lackiego, 28 listopada 2020 (fot. Elżbieta Janicka)

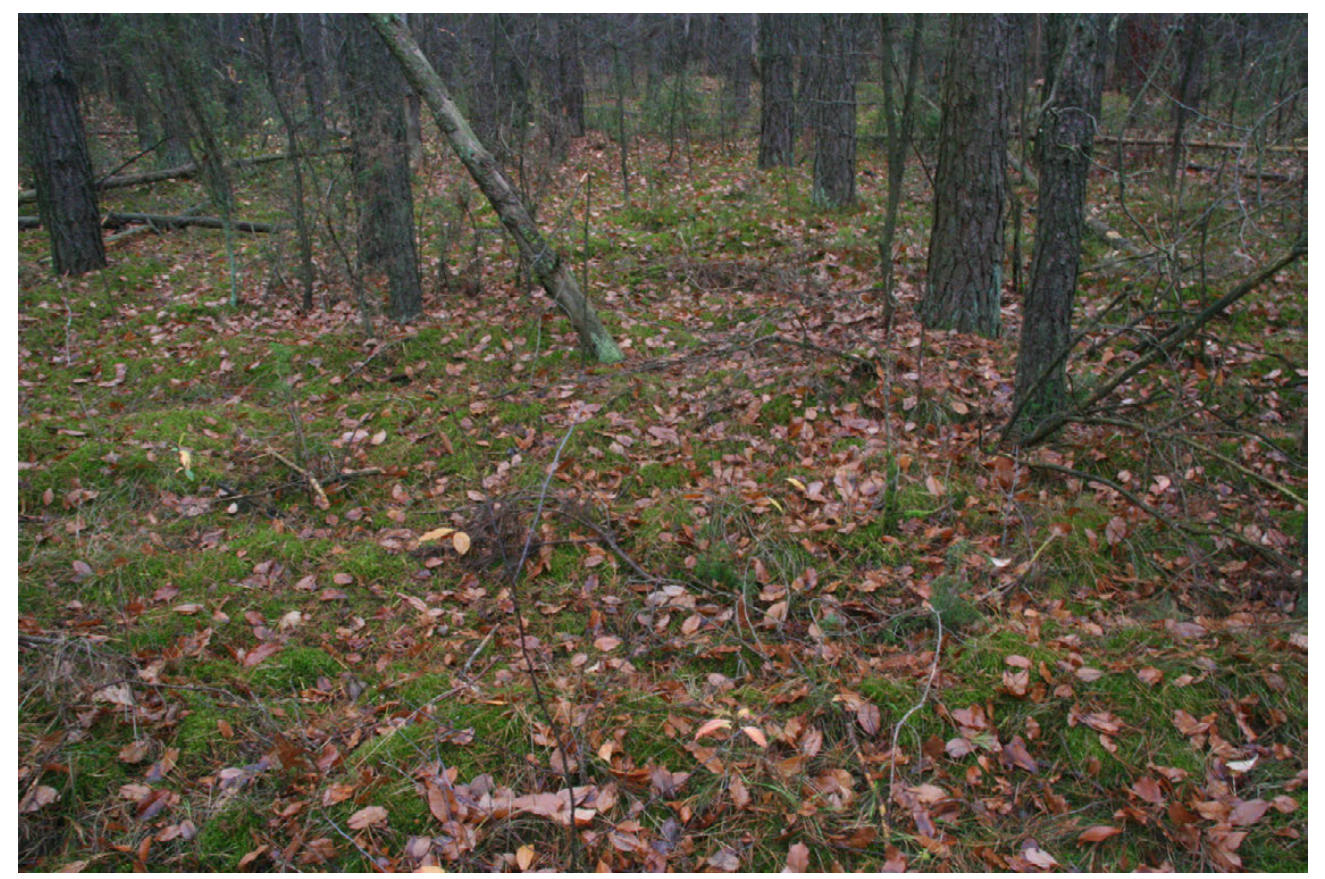

Rzeźba terenu w części zachodniej nowego cmentarza żydowskiego. Wypukłości odpowiadają najprawdopodobniej indywidualnym pochówkom. Widok z alei cmentarnej w kierunku wschodnim południowe peryferie Kosowa Lackiego, 28 listopada 2020 (fot. Elżbieta Janicka) 


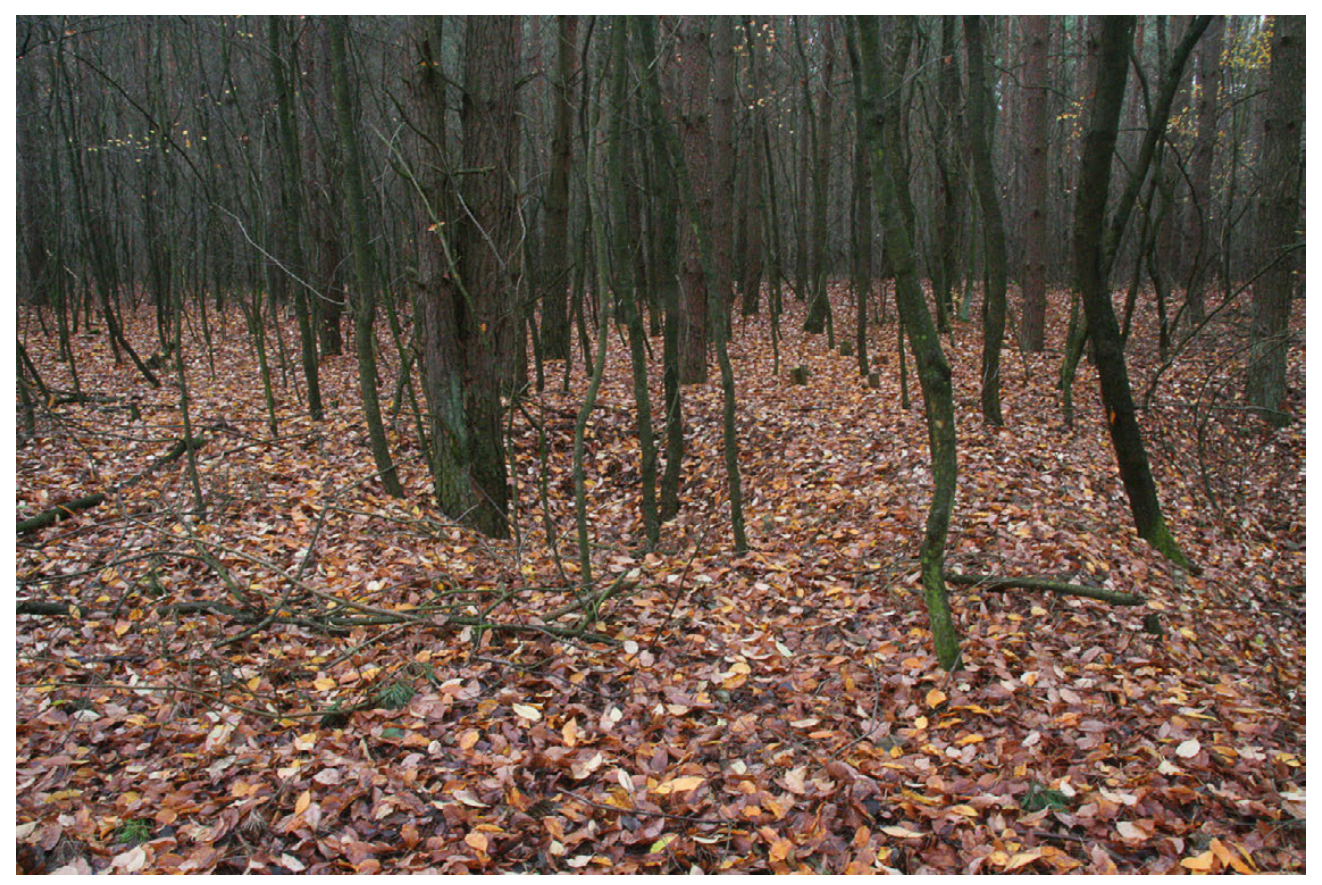

Rzeźba terenu w części wschodniej nowego cmentarza żydowskiego. W centrum obrazu i dalej z prawej strony widać wklęsłości odpowiadające najprawdopodobniej polskim wykopkom. Nie należy ich mylić z olbrzymimi masowymi mogiłami, które na cmentarzu również istnieją, lecz nie potrafiłam ich uwidocznić na fotografii. Widok w kierunku zachodnim - południowe peryferie Kosowa Lackiego, 28 listopada 2020 (fot. Elżbieta Janicka)

„Według raportu Czesława Zawadzkiego, ps. «Gozdawski», szefa wywiadu Okręgu XII Narodowych Sił Zbrojnych, na cmentarzu w Kosowie Lackim wykopano doły o długości 100 m, w których grzebano ciała osób zmarłych lub zabitych podczas transportu do niemieckiego nazistowskiego obozu śmierci w Treblince" (Artur Ziontek, Żydzi Kosowa Lackiego, red. Artur Ziontek, Miejsko-Gminny Ośrodek Kultury, Kosów Lacki 2016; cyt. za: Bielawski, 2020, s. 47). Najprawdopodobniej - wedle powszechnego uzusu - były wśród nich również ofiary ówczesnego i późniejszego polowania na Żydów

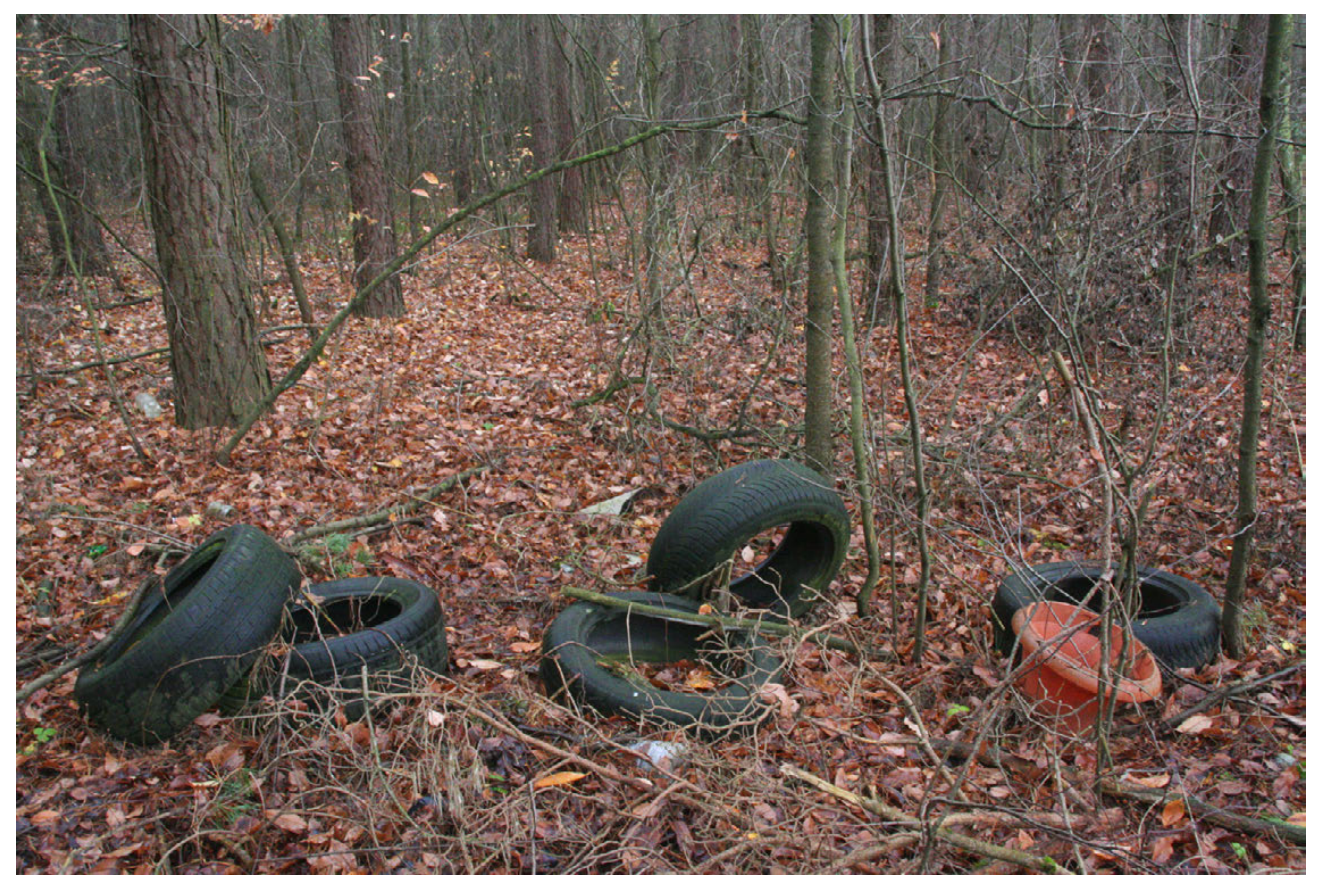

Południowo-wschodni narożnik nowego cmentarza żydowskiego. Widok w kierunku zachodnim południowe peryferie Kosowa Lackiego, 28 listopada 2020 (fot. Elżbieta Janicka) 


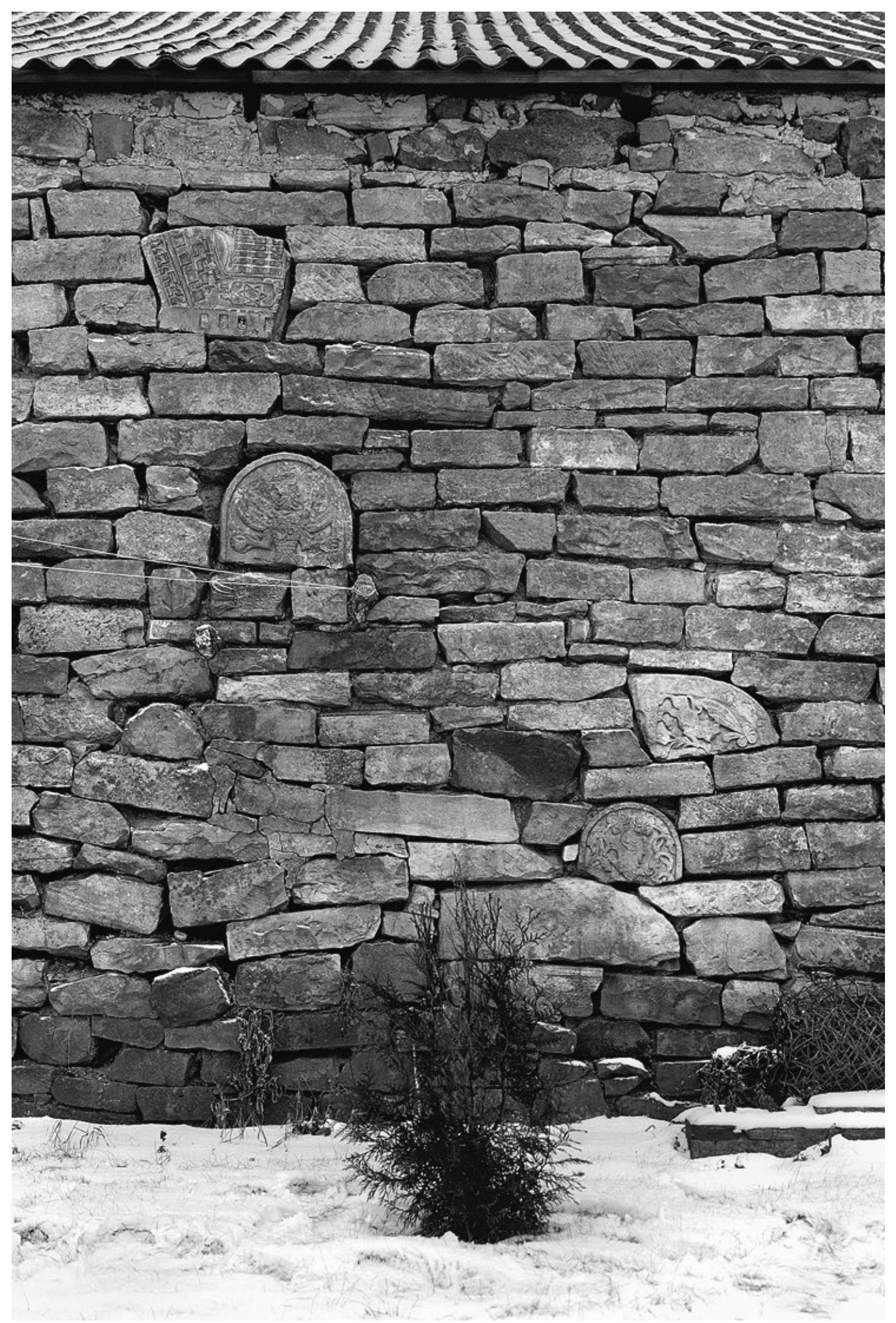

Obora, 1939-1945 (zbliżenie) - Przysucha, miasto w Mazowieckiem, XXI wiek (fot. Łukasz Baksik)

(๔ by Łukasz Baksik, dzięki uprzejmości Autora zdjęcia) 


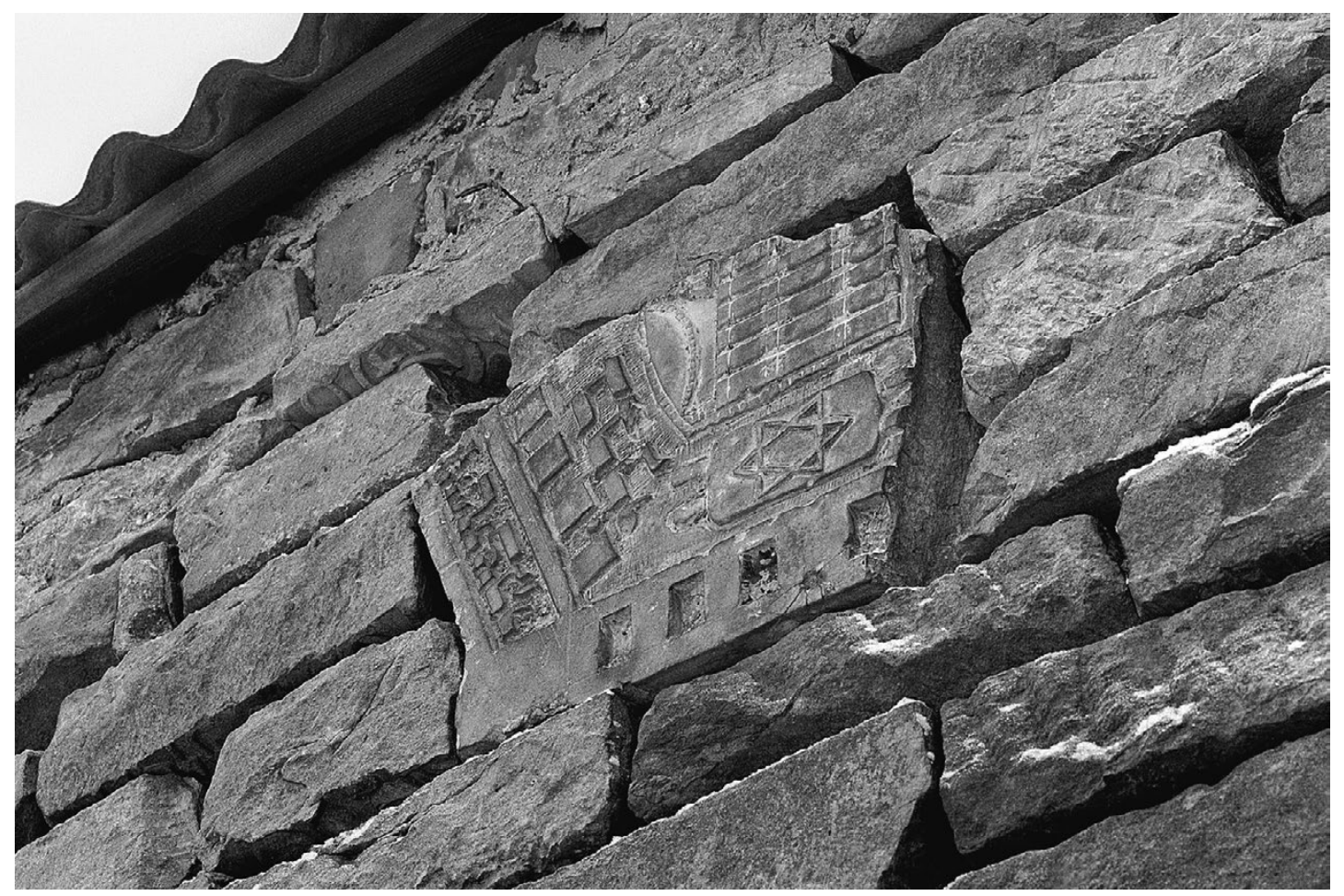

Obora, 1939-1945 (detal) - Przysucha, miasto w Mazowieckiem, XXI wiek (fot. Łukasz Baksik) (๔ by Łukasz Baksik, dzięki uprzejmości Autora zdjęcia)

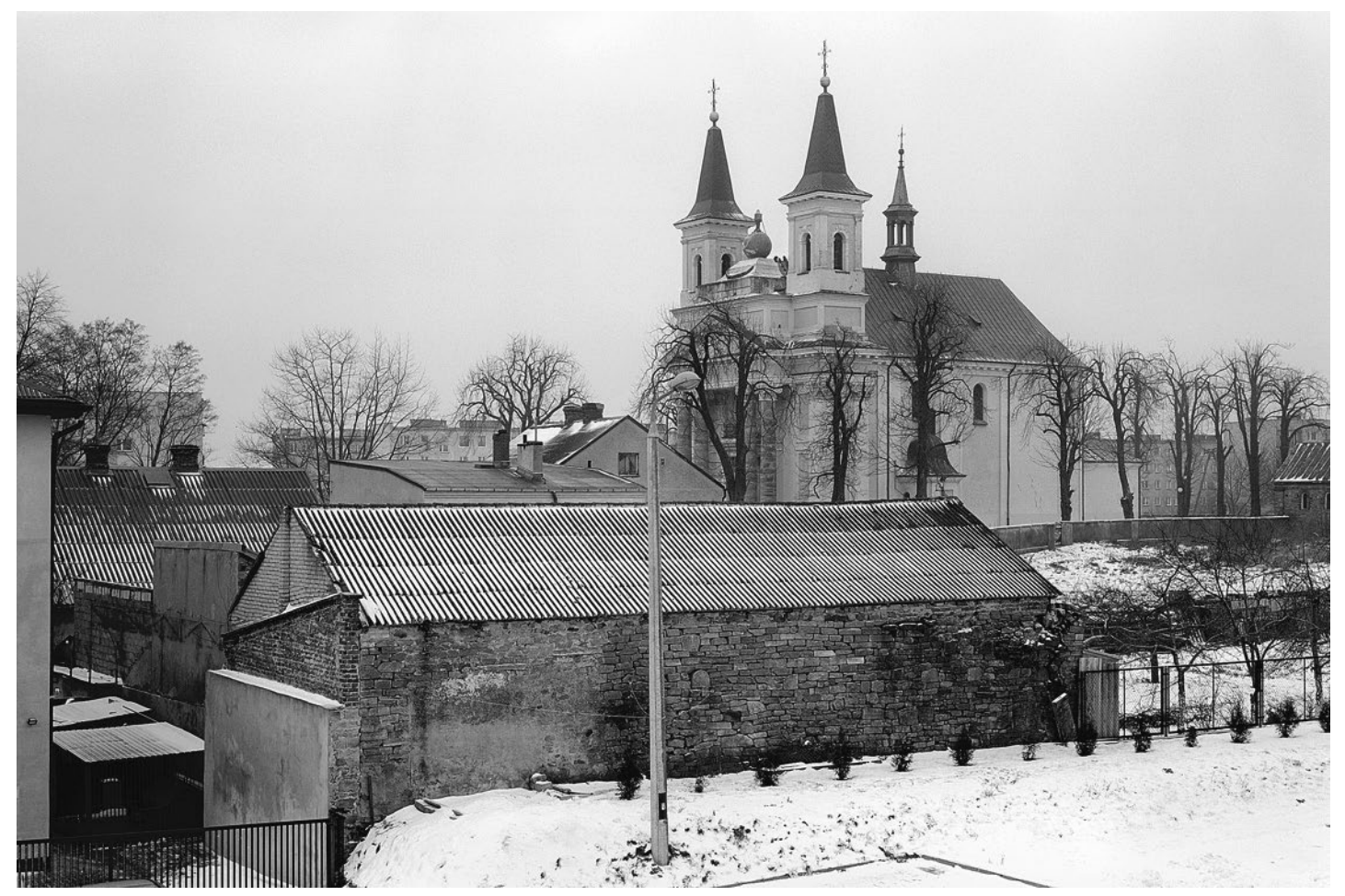

Obora, 1939-1945 (plan ogólny) - Przysucha, miasto w Mazowieckiem, XXI wiek (fot. Łukasz Baksik) (๔ by Łukasz Baksik, dzięki uprzejmości Autora zdjęcia) 
Kawałki macew położone inskrypcjami do góry tworzą konstelację. Ich autorów łączyła i jednoczyła solidarność, zarazem wymuszona i wybrana ${ }^{61}$. Nie wiemy, kim byli. Religijnymi Żydami sprawującymi Kidusz ha-Szem? Bundystami ginącymi za naród żydowski? Syjonistami - prawicowymi czy lewicowymi - umierającymi z wołaniem Am Izrael Chaj? A może członkami inteligencji pragnącymi przynależeć do nieistniejącej polskiej wspólnoty opartej na obywatelstwie i łudzącymi się, że Polska to nie oni, Polska to nie Polacy, Polska to nie Polska (zob. Landau-Czajka, 2015). Można zakładać, że byli mężczyznami. Raczej młodymi, chociaż niekoniecznie. Raczej nie komunistycznymi internacjonalistami, bo ci - wraz z nastaniem operacji Barbarossa - przeważnie uchodzili w głąb ZSRR i jako jedyni w większości ocaleli mimo gehenny, którą przeszli wraz $\mathrm{z}$ innymi obywatelami i nie-obywatelami radzieckich republik.

Broń słabych jest słabą bronią. Tkacze kamiennego dywanu Czarnej Drogi dali radę przechwycić i zawłaszczyć narzędzia opresji dla własnych celów. Na tyle, na ile mogli. Ich sprzeciw i bunt pozostały daremne. Jednocześnie opisana powyżej plątanina niewiadomych jest chaotyczna i nieartykułowana jedynie na pozór. Nie jest ona bowiem brakiem komunikatu. Jest komunikatem. Spójnym i precyzyjnym. Świadectwem zbrodni i portretem zbrodniczej, antysemickiej cywilizacji. Dowodem rzeczowym i oskarżeniem. Interpelacją wdrukowaną w ziemię przez tych, którzy jednocześnie byli ścierani z jej powierzchni.

\section{Sygnatura}

Kręciliśmy zdjęcia w Treblince o każdej porze roku [...]. W samym obozie całymi dniami, nie umiejąc się zatrzymać, filmowałem pod każdym możliwym kątem stele i głazy, biegałem od jednego do drugiego, szukając perspektyw, wdrapałem się z moim operatorem na śliski kamienny wierzchotek wysokiego blockhauzu symbolizującego komorę gazową, aby zrobić stamtąd pełną panoramę trzysta sześćdziesiąt stopni, ukazującą ogólny widok tego miejsca o zachodzie słońca [...]. Chapuis, a przed nim Lubtchansky czy Glasberg zawsze mówili: „Po co wciąż filmować te kamienie? Masz ich dziesięć razy za dużo". Nigdy ich nie miałem za dużo, nie dość je filmowałem i musiałem jeszcze raz wrócić do Treblinki, żeby je sfilmować.

Claude Lanzmann (Lanzmann, 2010, ss. 462-463)

Lapidarium to wreszcie także powojenne założenie pomnikowe - z megalityczną bryłą główną i siedemnastoma tysiącami mniejszych kamieni oraz granitowymi blokami znaczącymi granicę byłego obozu zagłady. W odróżnieniu od kamieni lokalnych, czyli macew z Czarnej Drogi, są to implanty z daleka: przeważnie granit lub sjenit, kwarcyt,

61 Na temat wyboru tego, co narzucone przez wroga, w historii Żydów Europy Wschodniej por. powieść Imre Kertésza Los utracony (Kertész, 1975) oraz film Istvána Szabó Sonnenschein (Szabó,1999). 
porfir, bazalt, piaskowiec i może kilka wapieni62. Co się tyczy granitu, wyjściowy plan przewidywał beżowo-różowy granit fiński lub szwedzki granit labradoryt. Z pomysłu jednakże zrezygnowano z przyczyn finansowych. W rezultacie granity są szare i pochodzą z niemieckiej niegdyś części dzisiejszej Polski. Z Rogoźnicy (Gross Rosen), Strzeblowa (Ströbel), Strzelina (Strehlen), Zimnika (Kalthaus). Podobnie jak sjenity - z Przedborowej (Schönheide). Czy bazalty - z Księginek (Kerzdorf). Kwarcyty przywieziono z Wiśniówki pod Kielcami w Polsce centralnej. Porfiry - z małopolskiej Miękini. Zachowała się ich lista, sporządzona własnoręcznie przez Adama Haupta. Jak chodzi o wapień i piaskowiec - jeśli to one - nie udało mi się ustalić ich pochodzenia. Niczym niektóre z kamieni Czarnej Drogi, część kamieni porozstawianych na betonie nosi napisy. Wyryto w nich imiona własne, nienależące już jednak do jednostek. Miały to być nazwy miast i miasteczek, z których pochodzili Żydzi zamordowani w Treblince ${ }^{63}$. Niektóre jednak nie są takimi nazwami. Są sygnaturą mordercy.

Jeden z napisów głosi... „Jedwabne”. Żydzi Jedwabnego nie zostali zagazowani w Treblince. Żydzi Jedwabnego zostali spędzeni przez swoich polskich sąsiadów na rynek u stóp kościoła. Po całym dniu tortur zaś zagnani do pobliskiej stodoły i spaleni żywcem. Przez Polaków. Było to 10 lipca 1941 roku. Treblinka II otworzyła swe podwoje 23 lipca roku następnego. Obie daty dzieli zatem ponad rok. Gdy znalazłam się w Treblince po raz pierwszy - był wówczas 10 lipca i rok 2004 - nazwa „Jedwabne” była usunięta, a raczej zasłonięta, schowana pod grubą warstwą szarej farby. To samo dotyczyło nazw takich, jak Radziłów, Grajewo, Kleszczele czy Goniądz. Później jednak odrestaurowano je wszystkie starannie przy użyciu farby czarnej, dobrze widocznej z daleka. W literaturze przedmiotu nazywa się to kłamstwem jedwabieńskim. Stanowi ono polską wersję kłamstwa oświęcimskiego, czyli negacjonizmu. Kłamstwo jedwabieńskie nie polega na negacji samego faktu zbrodni jedwabieńskiej i innych podobnych. Polega natomiast na negacji ich polskiego autorstwa.

Skoncentrowana na rozwoju wydarzeń na betonie, nie zauważyłam momentu nazewniczej restytucji. Fotografie napisów ukrytych pod szarą farbą wykonałam 9 września 2014 roku. Ich restauracja musiała być zatem współczesna lub późniejsza w stosunku

62 „[N]iewielka ilość małych, czarnych bazaltowych kamieni miała symbolizować dzieci, które tu zostały zamordowane wraz ze swym opiekunem, nauczycielem i mistrzem - Korczakiem" (Radecka, 2013, s. 312). Rzecz jasna, Henryk (Hersz) Goldszmit, zwany Januszem Korczakiem, nie był jedynym żydowskim wychowawcą, który nie opuścił swoich wychowanków, a jego wychowankowie nie byli jedynymi żydowskimi dziećmi zamordowanymi w Treblince. Ostatecznie szary granitowy kamień z napisem „Janusz Korczak i dzieci” odsłonięto w 1978 roku, odstępując od rozważanego początkowo projektu kamiennej galerii sław.,Janusz Korczak i dzieci” oraz kamień dedykowany Męczennikom Getta Warszawskiego - niezależny od kamienia z napisem „Warszawa” - to jedyne upamiętnienia wyodrębnionych grup ofiar na terenie dawnego obozu śmierci.

63 „W beton zostało wprowadzonych 17 tys. słupów granitowych różnej wielkości, mających odzwierciedlić setki tysięcy ofiar. Na większych z nich (130) wyryto napisy miejscowości, z których wywieziono do obozu zagłady w Treblince co najmniej 1000 Żydów. W 1998 r. dopisano kolejne miejscowości na wniosek Benjamina Majerczyka, sekretarza generalnego Związku Żydów Pochodzących z Polski w Izraelu. Obecnie nazwy państw i miejscowości znajdują się na 221 kamieniach" (Zawadka, 2015, s. 45). Prócz kamieni na płytach betonowych „[p]rzy symbolicznej rampie usytuowano głazy z nazwami państw, z których przybywały ofiary: Austria, Belgia, Bułgaria, Czechosłowacja, Francja, Grecja, Jugosławia, Niemcy, Polska, ZSRR. Jedenasty kamień z napisem «Macedonia» ustawiono w 2008 r." (Zawadka, 2015, s. 45). 


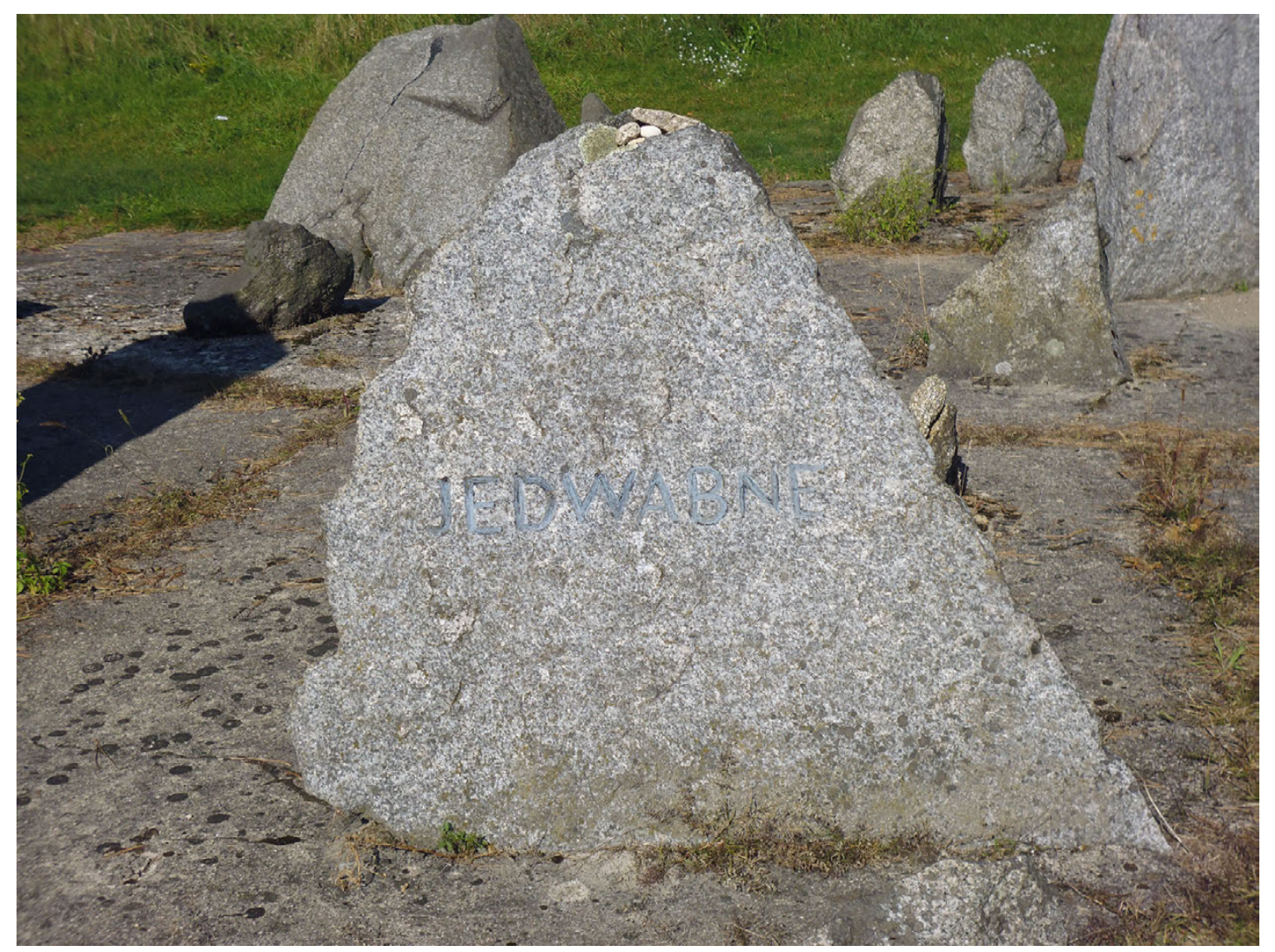

Kamień Jedwabnego - Treblinka II, 7 września 2014 (fot. Elżbieta Janicka)

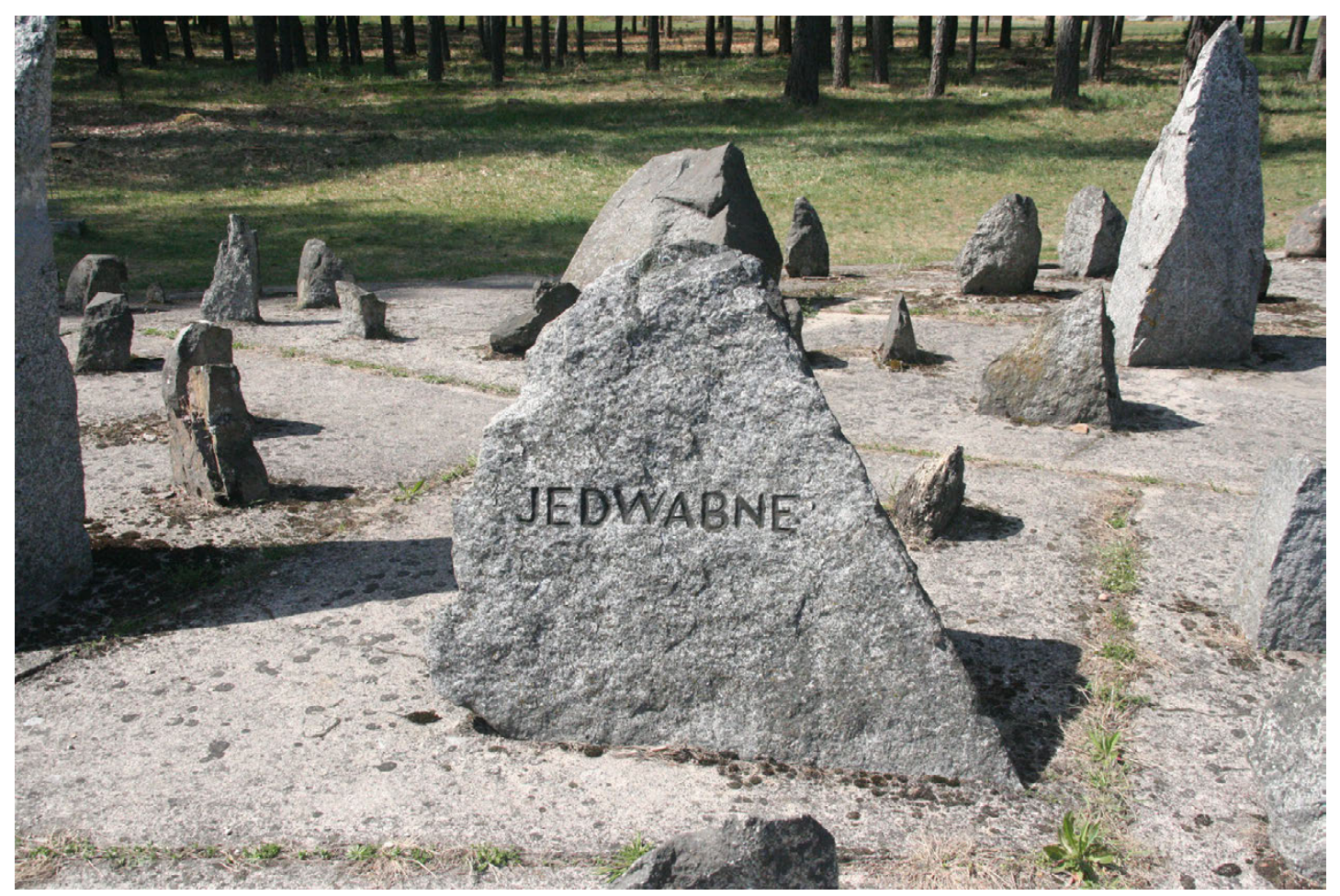

Kamień Jedwabnego - Treblinka II, 26 kwietnia 2019 (fot. Elżbieta Janicka) 


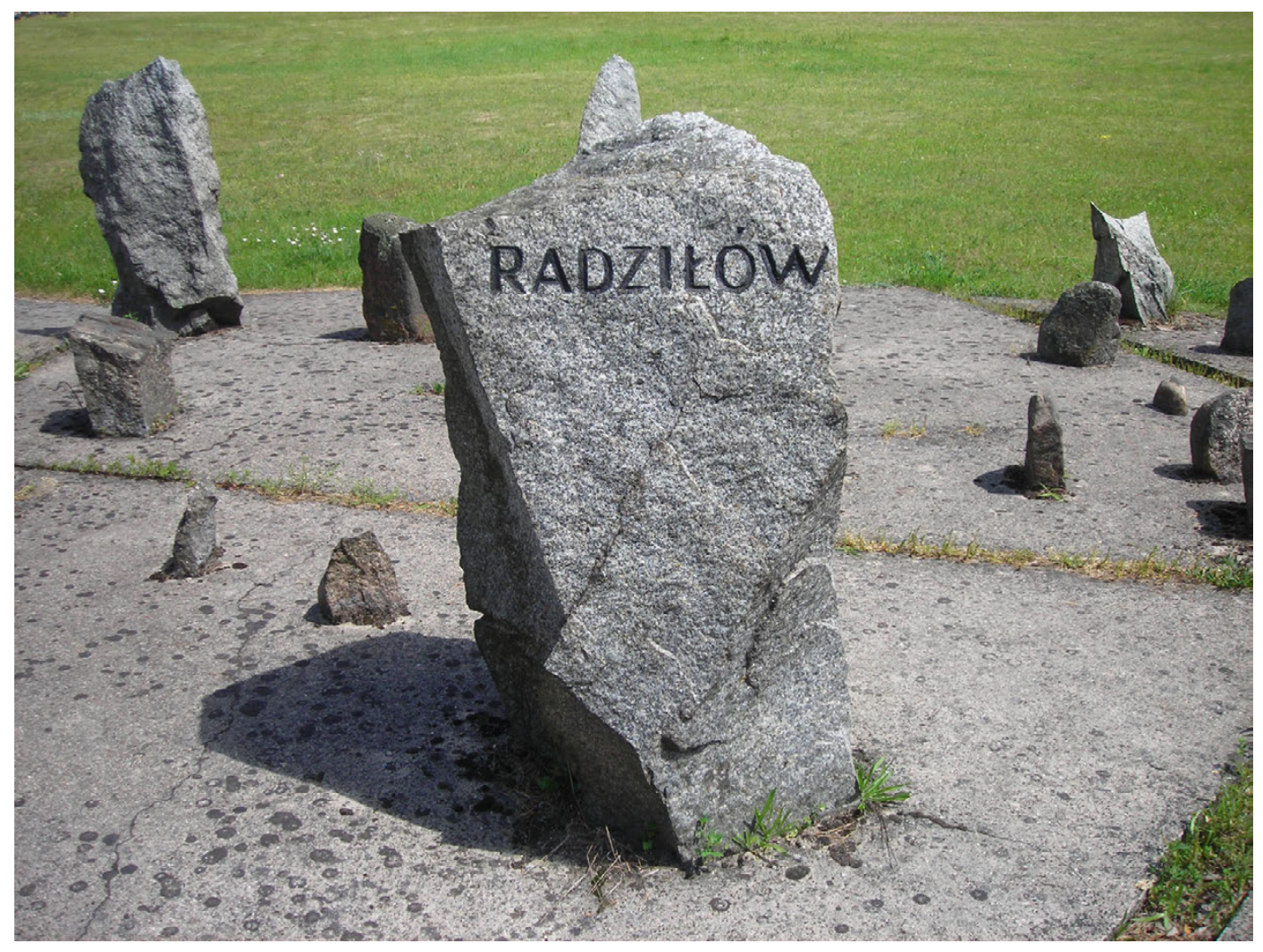

Kamień Radziłowa - Treblinka II, 12 czerwca 2016 (fot. Elżbieta Janicka)

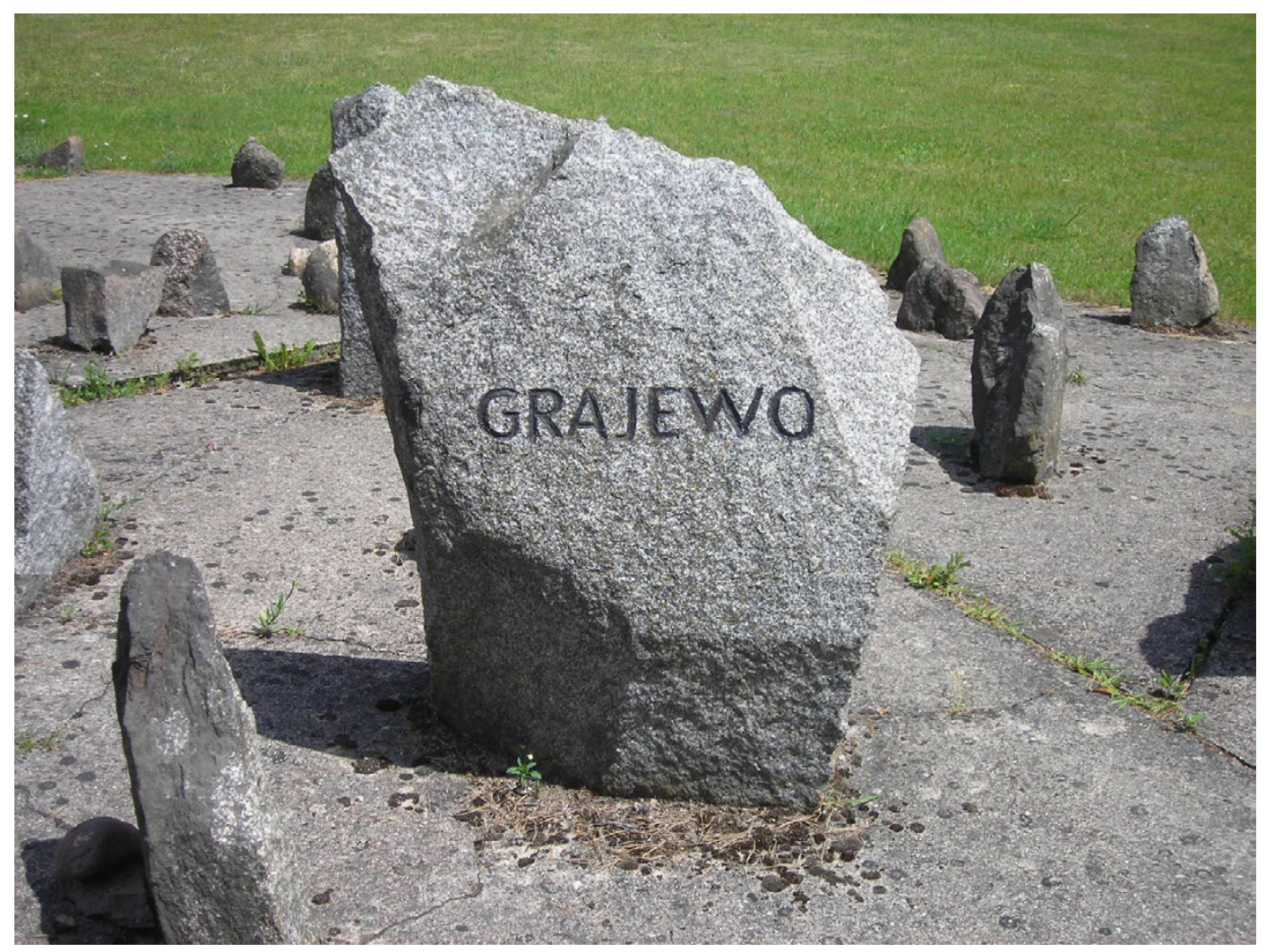

Kamień Grajewa - Treblinka II, 12 czerwca 2016 (fot. Elżbieta Janicka) 
do zwycięstwa polskiej skrajnej prawicy w wyborach prezydenckich i parlamentarnych rok później, kiedy to kłamstwo jedwabieńskie zostało ustanowione doktryną państwową. Wszelako nazwa „Jedwabne” nigdy nie została usunięta z oficjalnej broszury Muzeum Walki i Męczeństwa. Jej wydania z lat 2009 i 2014 są pod tym względem identyczne (Kopówka, 2009, s. 13, 2014, s. 14). Przed ogólnokrajową debatą jedwabieńską z lat 2000-2001 ten napis był kłamstwem. Lecz czymże jest on teraz, gdy polskie sprawstwo zbrodni jedwabieńskiej jest wiadome całemu światu? Czy może on być kłamstwem w rzeczywistości, w której wszyscy znają prawdę? Czy może jest on konfirmacją i afirmacją polskiego udziału w niemieckim przedsięwzięciu eksterminacyjnym wymierzonym w Żydów? Obecna wizualizacja - sposób, w jaki rzecz wygląda - zdaje się chełpliwie potwierdzać to drugie przypuszczenie.

Kompulsja podkreślania polskiego wkładu w Zagładę i wpisywania go w szerszy obraz wydarzeń kieruje uwagę na to, co oficjalne dyskursy usuwają z zasięgu wzroku. A mianowicie: antysemickie kontinuum. Czarna Droga - wyprodukowana przez niemiecki reżim nazistowski - nie jest odizolowanym artefaktem, lecz przykładem jednym $z$ wielu. Powinna być zatem lokowana w szerokim spektrum antysemickich praktyk typowych dla chrześcijaństwa. Szczególnie, że ten rodzaj unicestwiania był praktykowany w powojennej Polsce. (W powojennym Zamościu na przykład destrukcja dwóch żydowskich cmentarzy obejmowała ekshumację zwłok i ich publiczne palenie). Zrabowane macewy zostały rozwłóczone po całym kraju. „Może wiąże się to jakoś z tym, że wydawani na śmierć i mordowani przez współziomków Żydzi byli zakopywani przez morderców byle gdzie? Może więc te rozrzucone po Polsce macewy wywędrowały w poszukiwaniu nieżyjących?" - zastanawia się Jan Tomasz Gross (Gross, 2013, s. 15). Według niego, zważywszy, że kraj odmówił stawienia czoła własnej przeszłości, macewy mogą być teraz na właściwym miejscu: „Rezultat okazał się jednak odwrotny od zamierzonego i Żydzi zamiast zniknąć, będą już zawsze towarzyszyli kolejnym pokoleniom [...] aż do grobowej deski" (Gross, 2013, s. 16).

Kamień z napisem „Jedwabne” pozwala zobaczyć w nowym świetle również betonowe płyty, których wizualnie nie obrałam za odrębny temat. Ich obecność na zdjęciach - dyskretna i z pozoru poboczna - jest de facto wszechobecnością. Na poziomie wizualizacji nie są one centralne. Są jednakże - dosłownie - fundamentalne. Ten stan rzeczy okazuje się odzwierciedlać strukturę narracji o Zagładzie, w której polska obecność dyskretna i z pozoru poboczna - jest konsekwentnie lekceważona, jeśli nie całkowicie ignorowana, podczas gdy w świecie rzeczywistym stanowiła funkcjonalną ramę, w której operowali tak zwani Niemcy, a nie na odwrót. Abstrahując od interpretacji, te dwadzieścia dwa tysiące metrów kwadratowych betonu pokrywające rozległą łąkę Treblinki II stanowi widzialny ślad, dowód i nieintencjonalne upamiętnienie polskiego kontekstu Zagłady. 


\section{Jak daleko stąd, jak blisko}

Wyliczając źródła, z których korzystałam, nie wymieniłam imponującego Zielnika w pięciu tomach z przełomu XVI i XVII wieku (1580-1610), autorstwa Szymona Syreńskiego (Syreński, 2017b). Jego okazałość (1584 strony), naukowa rzetelność i piękno to sława i chwała najstarszego polskiego uniwersytetu, jednego z najstarszych w Europie: Universitatis Jagiellonicae Cracoviaensis. Szymon Syreński, lekarz i botanik, był jednym z najbardziej renomowanych profesorów tej uczelni. Zielnik Syreniusza znałam ze szkoty jako pomnik renesansu i nauki, nazywanych polskim renesansem i nauką polską. A zatem wiedziałam. Ale zapomniałam. Przypomniałam sobie dopiero, pracując nad konkluzją tego tekstu. Pospieszyłam do Biblioteki Narodowej. Zanurzyłam się w pięciu tomach epistemologicznej i estetycznej rozkoszy.

Pierwotny projekt arcydzieła przewidywał osiem tomów. Trzy ostatnie z przeznaczeniem dla... minerałów i zwierząt. Syreniusz zmarł, gdy rzecz była pod prasą drukarską. Niedługo po nim zmarł także egzekutor jego testamentu, Gabriel Joannicy, lekarz Anny Wazówny zwanej „królową botaniki polskiej”, gdyż to ona - wnuczka Zygmunta Starego, siostra Zygmunta III Wazy - sfinansowała publikację pierwszych pięciu tomów pracy Syreńskiego. Tomy od szóstego do ósmego przepadły, lecz z entuzjazmem napawałam się tymi, które zaistniały w druku. Wszystko po to, by na końcu Ksiąg piątych natrafić na traktat... O Żydziech rzecz krótka (Syreński, 2017a) - ujęte w najprzedniejszej polszczyźnie, cztery strony esencjalnej antysemickiej nienawiści podsycanej chrześcijańską wiarą w żydowskie bogobójstwo i jego późniejszą seryjną imitację: mord rytualny. Podtytuł traktatu głosi: „O srogim okrucieństwie niewiernych Żydów / którym się na dziatkach Chrześcianskich / z dawnego y wściekłego postanowienia / co rok pastwią / świadectwa / z poważnych i wiary godnych pisarzów / przez D. Szymona Syrenskiego / Medyka Krakowskiego / zebrane" (Syreński, 2017a, s. 1536).

Części traktatu są następujące: Żydowskie morderstwa dzieci chrześcianskich; S. Symon Tridenski; Przyczyny okrucienstwa; Wypędzenie Żydów; Przestroga potrzebna; Żydowskie wolności; Zkąd idą; Krew chrześcianska na co Żydom; W Krakowie dziecię zabili; W Litwie [obie składowe Rzeczypospolitej zostały zaatakowane]; S. Ambrożego kara Theodozyusza ${ }^{64}$; lego [św. Ambrożego] list; Bożnica się Bog brzydzi; Towarzystwo z Żydy; Okrucienstwo nad Chrystusem [„prawdziwem Messyaszem”, jak Syreniusz nie omieszkał dodać], Druga historia; Okrucienstwo na Chrześciany. Ad secula seculorum. Amen.

Szymon Syreński był poważnym uczonym. Wiedział, że Żydzi obserwują zakaz spożywania krwi - nieważne, zwierzęcej czy ludzkiej. Stąd wydedukował, że krwi chrześcijan

64 „Ambroży, nawiązując do wcześniejszego edyktu cesarza Magnusa Maximusa potępiającego rzymskich chrześcijan za spalenie synagogi, przestrzegł Teodozjusza, że lud ogłosił wówczas, iż «cesarz stał się Żydem», implikując że jeśli Teodozjusz próbowałby zastosować prawo, by chronić swoich żydowskich poddanych, będzie postrzegany w podobny sposób [por. David Nirenberg, Anti-Judaism: The Western Tradition (New York: W.W.. Norton, 2013), ss. 117-118]" https://en.wikipedia.org/wiki/Ambrose (17.09.2019). 
potrzebują do innych celów. Jego wywód jest pełen drobiazgowych danych, erudycyjnych cytatów i szczegółowych odniesień. Wśród instancji potępiających Żydów poczesne miejsce zjamują sami Żydzi - poddani torturom lub... ochrzczeni. „Żydowie krzczeni”. Brzmi znajomo. W średniowieczu i renesansie - jak się okazuje - chrzest nie czynił z wyznawcy judaizmu chrześcijanina. Od samego początku skutkował co najwyżej „Żydem krzczonym". Dlaczego więc nawet badacze mają skłonność wierzyć w istnienie antyjudaizmu, skoro porzucenie judaizmu nie zmywało żydowskiego piętna i nie rozbrajało nienawiści do jego nosicieli? To nie był antyjudaizm. To był antysemityzm, który nie miał nic wspólnego z wyznaniem osoby postrzeganej jako Żyd przez grupę dominującą. Dokładnie jak dzisiaj i jak w przypadku piętnastowiecznej hiszpańskiej katolickiej zasady limpieza de sangre.

W tym porządku nie można przestać być zabójcą Boga w oczach „panów sytuacji”. Jedyny sposób na to jest taki, by chrześcijanie przestali być „panami sytuacji” lub by „panowie sytuacji” przestali być chrześcijanami, nie absorbując po drodze kolejnych niereligijnych mutacji antysemityzmu. Gdyż to antysemityzm jest źródłem antysemickiej opresji. (Problem następny stanowi zaś instytucja „panów sytuacji”, czyli sama zasada dominacji). Syreniusz opisuje masakry na Żydach wynikające z chrześcijańskiej wiary w żydowskie deicidum. Bicie, torturowanie, palenie żywcem. Legitymizuje przemoc antysemicką jako usprawiedliwioną metodę postępowania wobec Żydów, którzy nie chcą przestać być Żydami (mission impossible tak czy owak, jak w każdym przypadku podwójnego wiązania) (zob. Bateson i in., 1956). Jako że paginacja Zielnika jest ciągła, O Żydziech rzecz krótka stanowi jego częścią integralną. Czy autor zaliczał Żydów do roślin, minerałów, zwierząt? W żaden sposób nie wytłumaczył swojej decyzji klasyfikacyjnej. Najwyraźniej uczestniczył w tej samej oczywistości społeczno-kulturowej, co jego czytelnicy należący do elity Rzeczypospolitej oraz jej prześwietnej akademii. Plus ratio quam vis.

Ufundowany przez Kazimierza Wielkiego w roku 1364 Uniwersytet Jagielloński posadowił się i zaczął ekspandować na terenie krakowskiego getta decyzją Władysława Jagiełły (począwszy od roku 1400). W konsekwencji królewskiej i kościelnej polityki, skutkującej kolejnymi prześladowaniami i pogromami, Żydzi musieli przystać na własne wygnanie, ogłaszając je dobrowolnym. Z początku zostali wysiedleni z obszaru, który uprzednio zezwolono im zajmować, czyli z krakowskiego getta (rok 1469), następnie zaś z miasta (rok 1495). Wśród „dobrowolnych” aktów z tego okresu był także ten, w którym Żydzi zrzekali się prawa wykonywania jakiegokolwiek rzemiosła oraz prowadzenia handlu detalicznego w mieście, pozbawiając się tym samym źródeł dochodu (rok 1485) (Zaremska, 2011). Pergamin z 1485 roku jest dzisiaj z dumą okazywany jako najwcześniejszy zachowany dokument $w$ języku hebrajskim na ziemiach polskich. Pamiętam dzień, w którym przynaglono mnie do podziwiania tego pomnika Złotego Wieku i Paradisi ludeorum w starej synagodze na krakowskim Kazimierzu, przekształconej w muzeum (wygasłej rasy?). Eksponat wyglądał wspaniale. Gablota była piękna. Oświetlenie zjawi- 


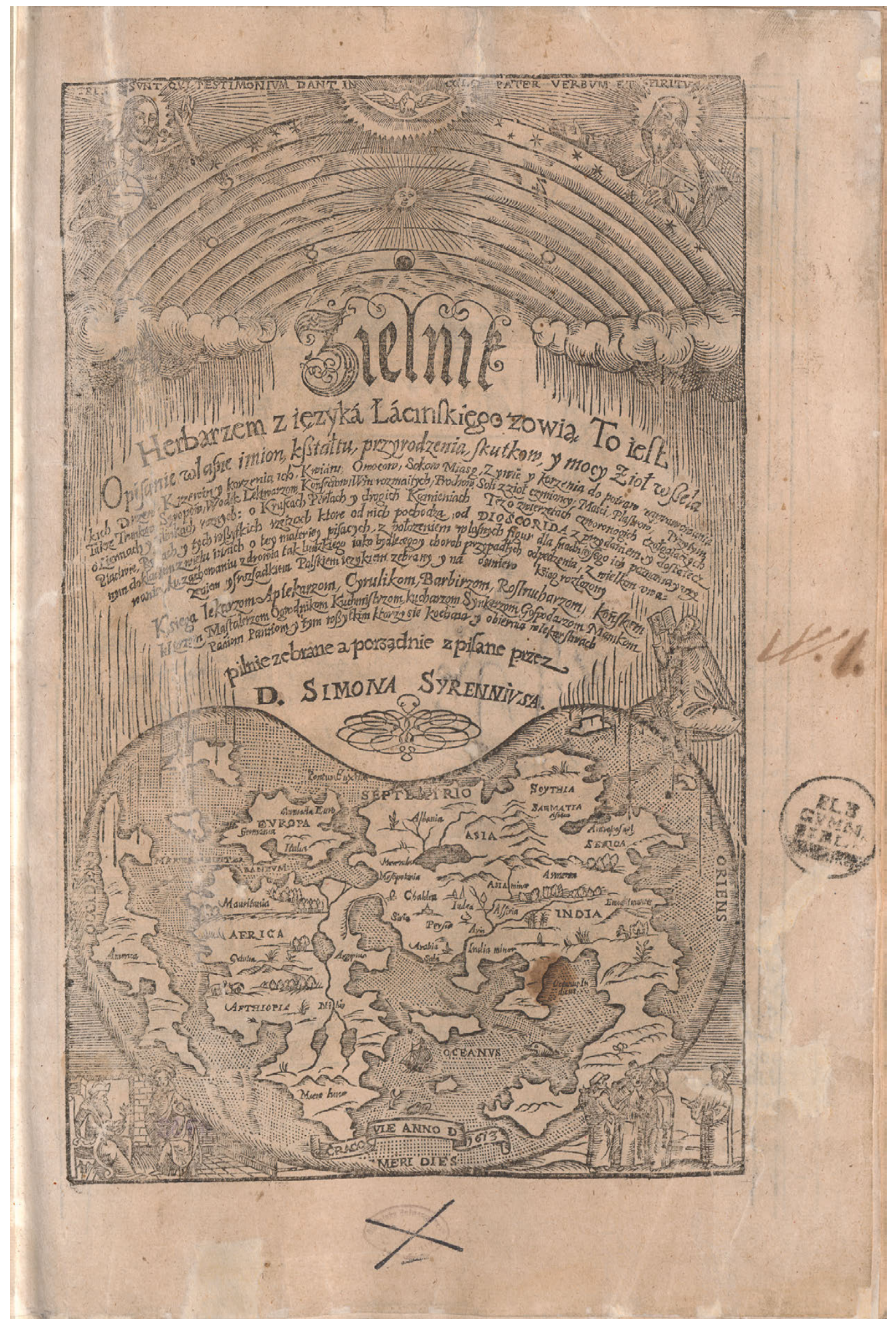

Fronstispis Zielnika Szymona Syreńskiego z mapą świata będącą projekcją powierzchni kuli na płaszczyznę w ptolemejskim porządku geocentrycznym. Dzieło powstawało w latach 1580-1610. Opublikowane zostało natomiast w roku 1613 (ze zbiorów Biblioteki Elbląskiej) 


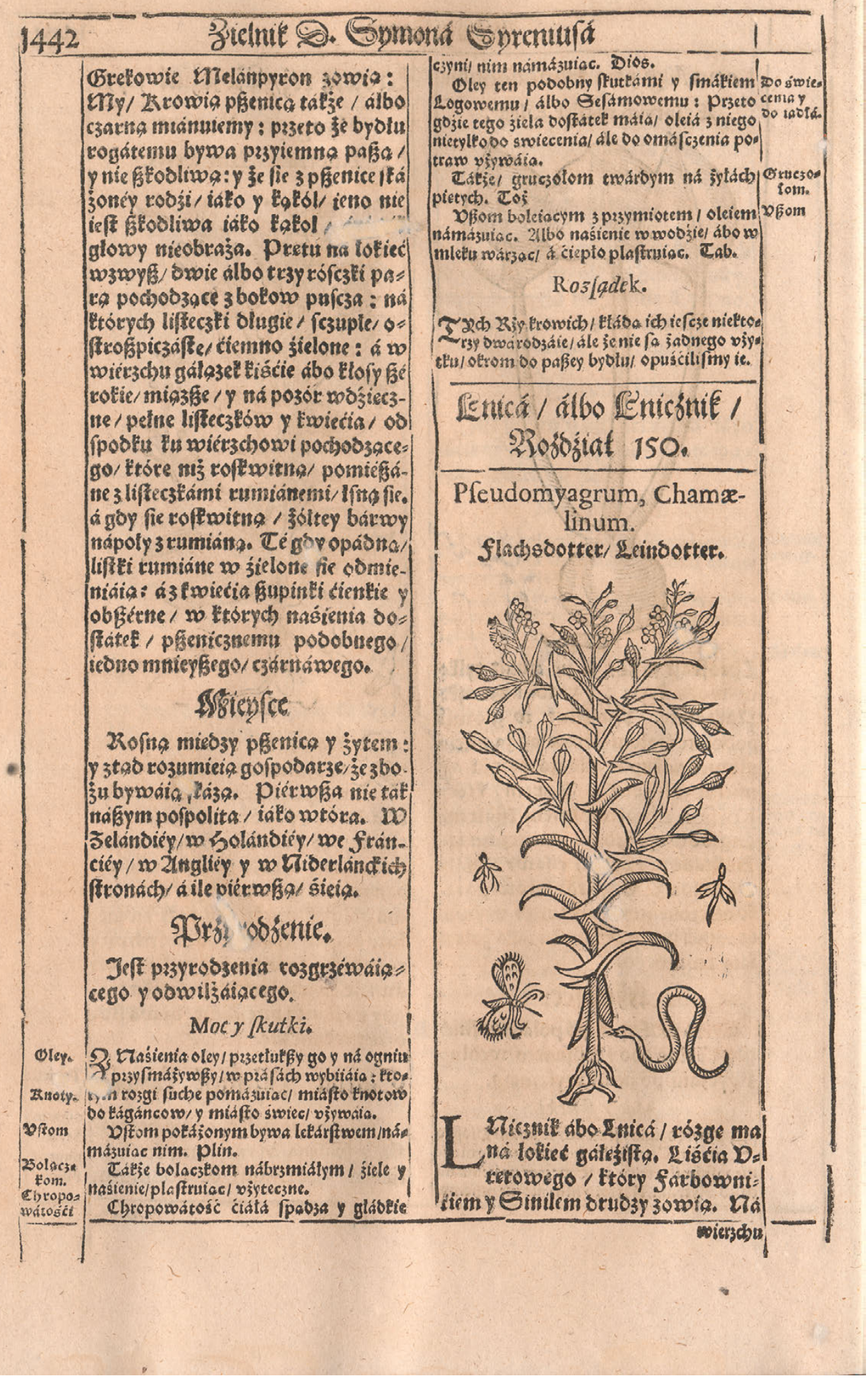

Lnica albo Inicznik z ksiąg piątych Zielnika Szymona Syreńskiego (s. 1442). Ilustracja „rozszerzona” o wizerunki owadów i płaza (ze zbiorów Biblioteki Elbląskiej) 


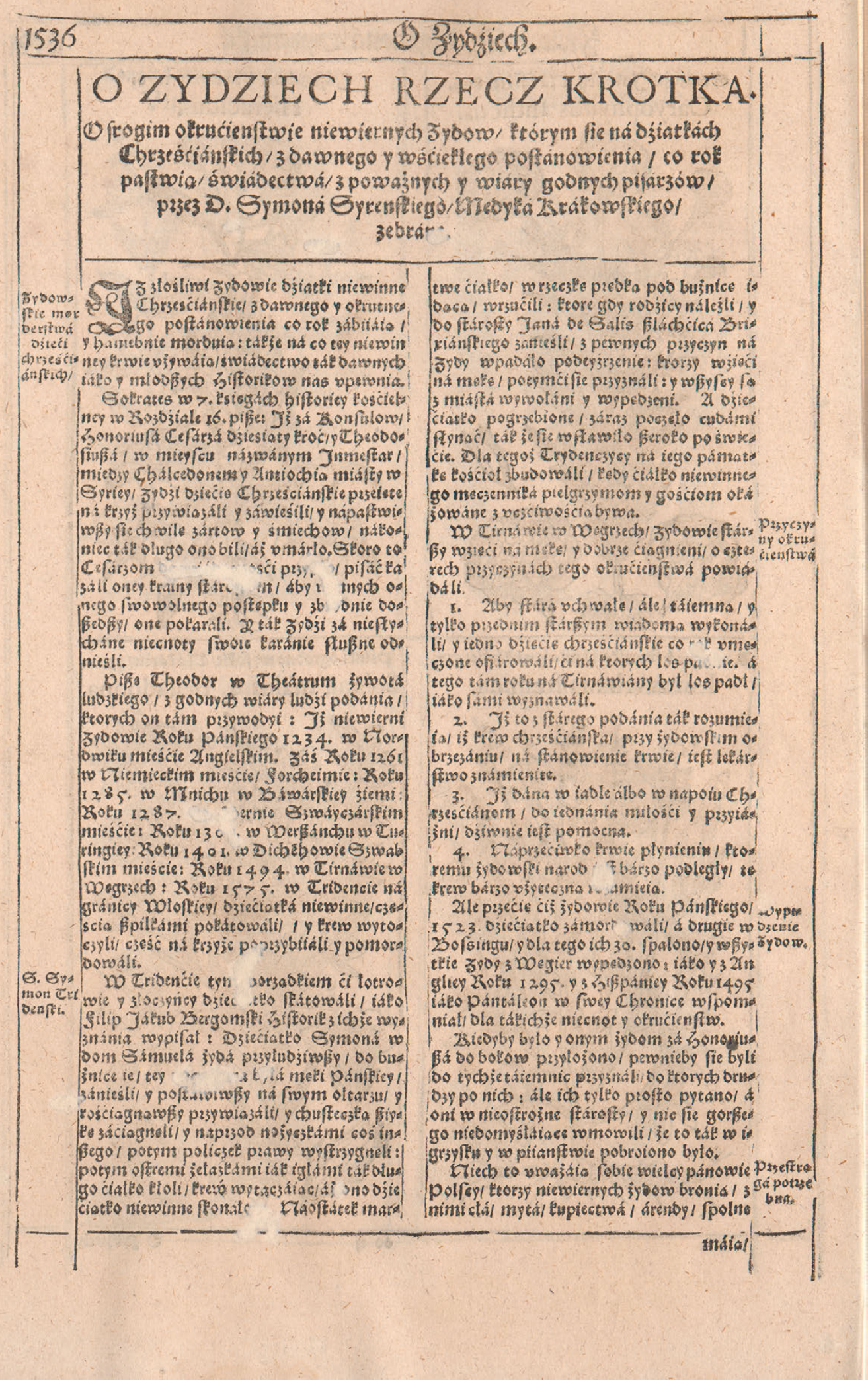

O Żydziech rzecz krótka z ksiąg piątych Zielnika Szymona Syreńskiego (s. 1536) (ze zbiorów Biblioteki Elbląskiej) 


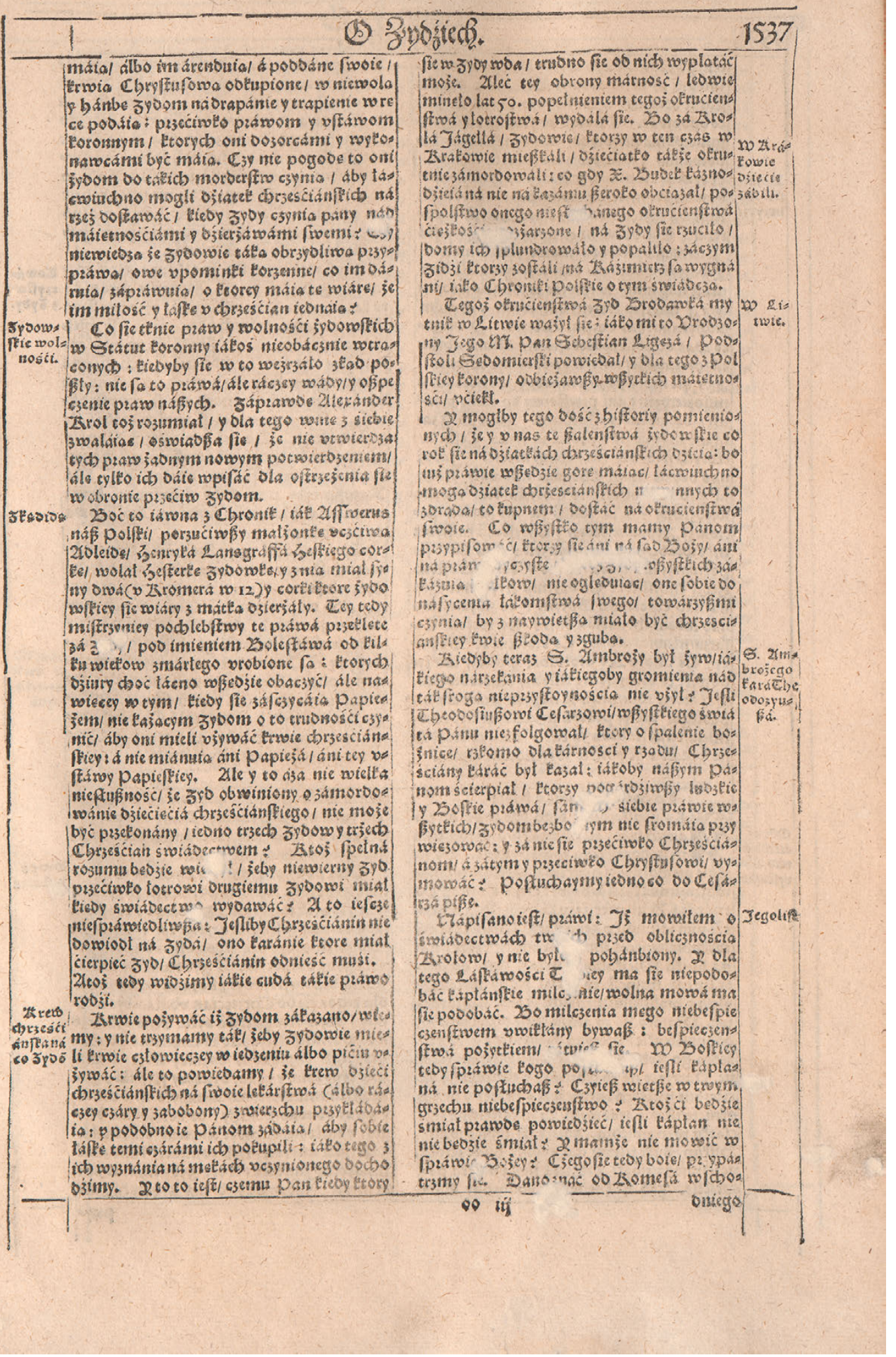

O Żydziech rzecz krótka z ksiąg piątych Zielnika Szymona Syreńskiego (s. 1537) (ze zbiorów Biblioteki Elbląskiej) 


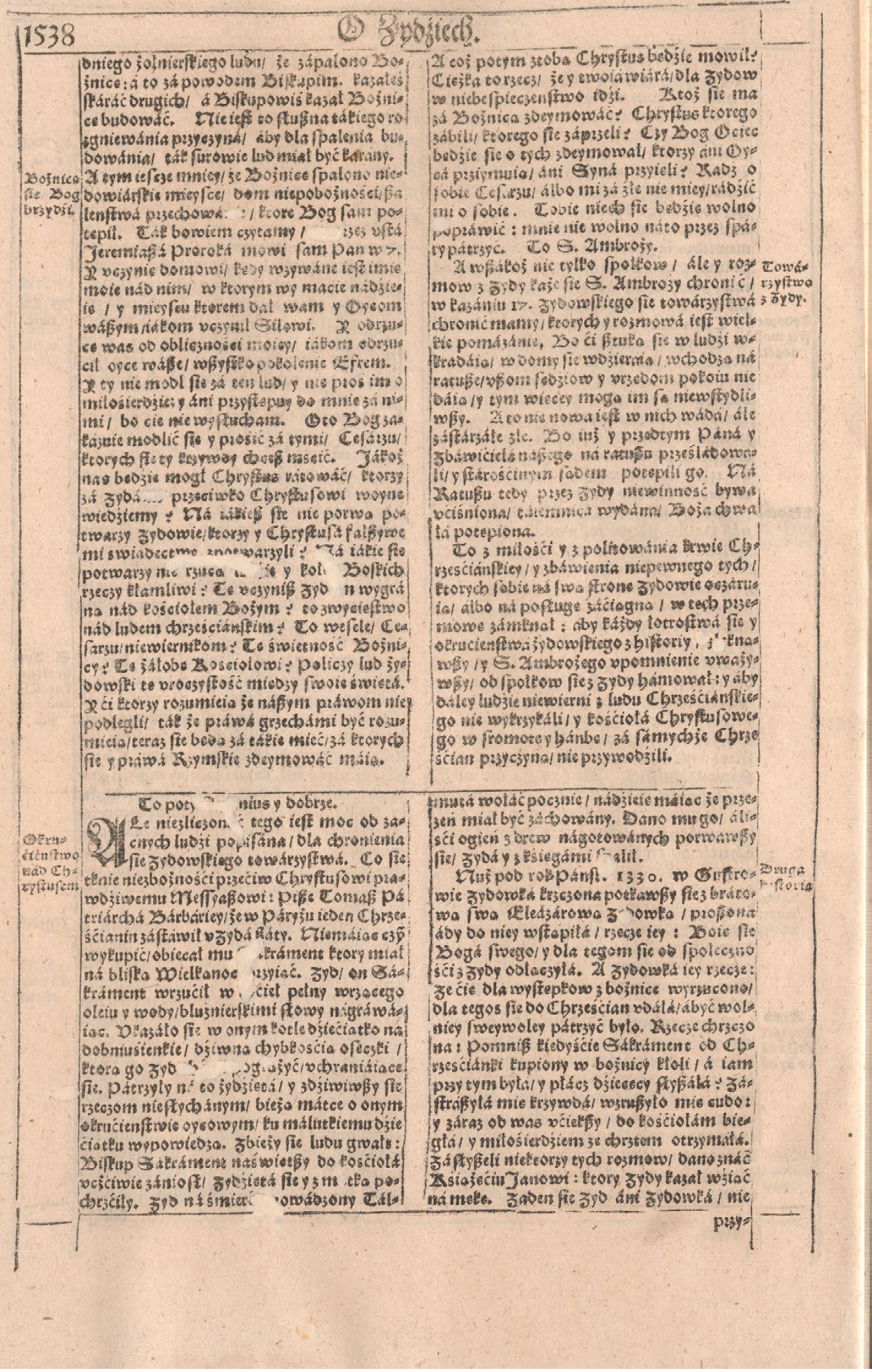

O Żydziech rzecz krótka z ksiąg piątych Zielnika Szymona Syreńskiego (s. 1538) (ze zbiorów Biblioteki Elbląskiej) 


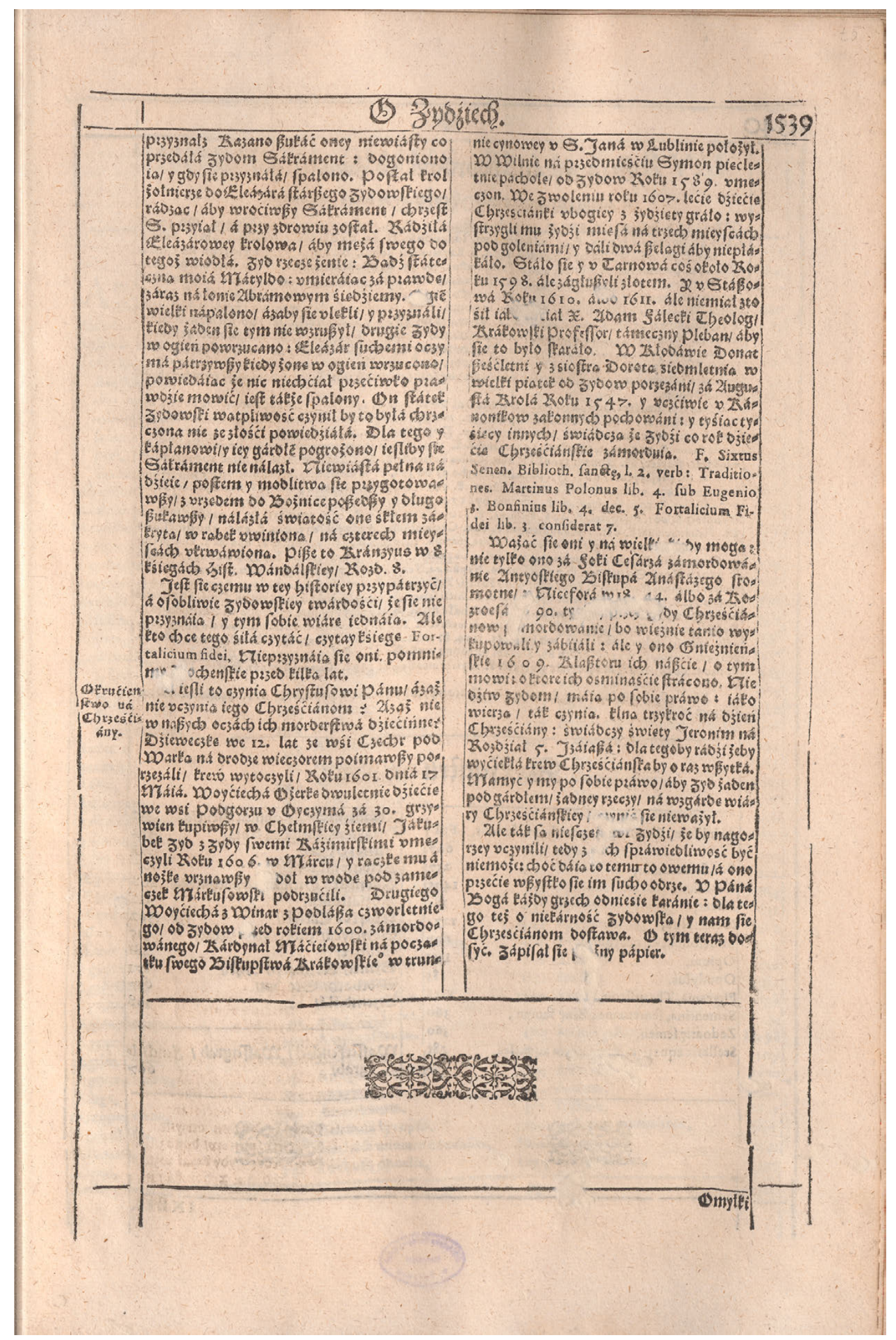

O Żydziech rzecz krótka z ksiąg piątych Zielnika Szymona Syreńskiego (s. 1539) (ze zbiorów Biblioteki Elbląskiej) 
skowe. Nie do końca dotarło do mnie wówczas, na co patrzę, ale zrozumiałam wystarczająco dużo, by poczuć się jak idiotka.

Uniwersytet Jagielloński rozwijał się i kwitł wraz ze swoim Ogrodem Profesorskim. Rzeczony Ogród Profesorski - wyposażony w zegar słoneczny i zestaw profesorskich biustów w togach i biretach - jest obramowany Collegium Maius, Collegium Minus, Collegium Medicum i ulicą Jagiellońską (zob. Matyjaszek, 2019)65. Czy Profesor - ekspertka od wierzby - czułaby się wykorzeniona także tutaj? Uniwersytet Jagielloński nigdy nie uznał za stosowne zająć stanowiska w sprawie swojej antysemickiej przeszłości. Krakowskie pogromy - raz na pokolenie - i codzienna, zrytualizowana przemoc antysemicka chrześcijańskich studentów nigdy nie przedostały się do narracji dominującej. Król Władysław Jagiełło, zwycięski wódz spod Grunwaldu, który na rzecz rozwoju akademii wygnał Żydów - nie z miasta wprawdzie (jeszcze), lecz z tego konkretnie skrawka ziemi - czuwa nad swoim osiągnięciem z pobliskiego pomnika.

Syrenius, Syrrenius, Sacranus znaczy po łacinie 'pochodzący, wywodzący się z Oświęcimia: Na oświęcimskim rynku znajduje się tablica upamiętniająca Szymona Syreńskiego, Syreniusza (1540-1611). Napis głosi: „Twórca pierwszego w Polsce dzieła botanicznego Zielnik herbarzem z języka łacińskiego zowia (1613). Doktor medycyny Uniwersytetu w Padwie, profesor Akademii Krakowskiej, lekarz ubogich w Krakowie. Wybitnemu uczonemu humaniście - miasto rodzinne Oświęcim 1984”. Miasto rodzinne. Oświęcim. Oszpicin. Auschwitz. Le hasard fait bien les choses. I wszystko dobre, co się dobrze kończy. Uniwersytet Jagielloński prosperuje. Miasto Oświęcim jest dumne. Rośliny kwitną. Podobnie polski antysemityzm. Tylko polscy Żydzi nie przetrwali. Jednakże nie ma już więcej potrzeby poświęcać im osobnych rozdziałów historii naturalnej, skoro zostali do niej wcieleni i stali się - niemożliwą do wyodrębnienia na powrót - częścią jej przedmiotu.

Od dwudziestego pierwszego wieku do renesansu. Pięć wieków wstecz. Dzieło Syreniusza. Jak daleko stąd, jak blisko... I jakże łatwo teraz wyobrazić sobie jeszcze poprzednie pięć wieków, aż do pierwszych form polskiej państwowości, uznanej przez chrześcijańską Europę za sprawą chrztu księcia i jego poddanych, zachęconych ogniem oraz mieczem. Longue durée i kompresja czasu jednocześnie. Zanim ich dotknęłam, nie przypuszczałam, że można ich dotknąć. Że w ogóle są dotykalne. Tymczasem istotnie są. Obie. Tak samo jak wzory kultury. „Surowiec w zamkniętym obiegu recyklingu definiuje się jako surowiec uzyskany z procesu produkcyjnego i ponownie skierowany do tego samego systemu produkcyjnego, wcześniej ewentualnie poddany utylizacji” - tako rzecze Internet ${ }^{66}$. I taki też jest przypadek antysemityzmu oraz jego ofiar.

Od Zielnika do Zielnika. Pełne koło. W obiegu zamkniętym. Na głucho.

65 Zwłaszcza wstęp i pierwsza część pt. Kraków: wytyczanie przestrzeni żydowskiej, ss. 7-136.

66 https://context.reverso.net/t\%C5\%82umaczenie/angielski-polski/closed-loop (01.10.2019). 
Zielnik z Treblinki jest bieżącym sprawozdaniem z (nie)dawnego miejsca Zagłady. Motywowany elementarną ambicją dokumentacyjną, na poziomie dosłownym i na metapoziomie koresponduje z tym, czym Zagłada była. A była ona wytworem kultury, kulturową produkcją. Integralną częścią antysemickiego kontinuum. Wieloelementową, a więc złożoną, lecz nieskomplikowaną. W tym sensie moja praca jest wymierzona przeciwko środowiskowej historii Zagłady, jeśli się ją praktykuje jako strategię uników, jak to częstokroć w Polsce bywa, a być nie powinno, jak uczy nas rozumiejąca lektura Syreniuszowego opus vitae - między wieloma innymi, jeśli nie wszystkimi innymi rzeczami. Wzory kultury, które uczyniły Zagładę wyobrażalną i możliwą, są dobrze widoczne i łatwo czytelne w całym przekroju dominującej kultury. Są również wpisane $w$ to, co mamy skłonność postrzegać jako naturę. Zakorzenione w przeszłości, władają teraźniejszością w kraju, który społeczną i kulturową energię inwestuje niemal bez reszty w rozbrojenie swojego potencjału przewartościowania oraz zmiany.

Nie wolno pochopnie uogólniać. W tym jednym zgadzam się z większością. Nie wolno pochopnie uogólniać, gdyż łatwo wówczas pominąć coś lub kogoś. Nie spieszyłam się więc i dziś z pełnym przekonaniem wnoszę rozpoznanie.

Cała Polska. Na żydowskich prochach. Naspidowana maksymalnie. Nawalona. Jak stodoła.

lato 2019 - lato 2020 


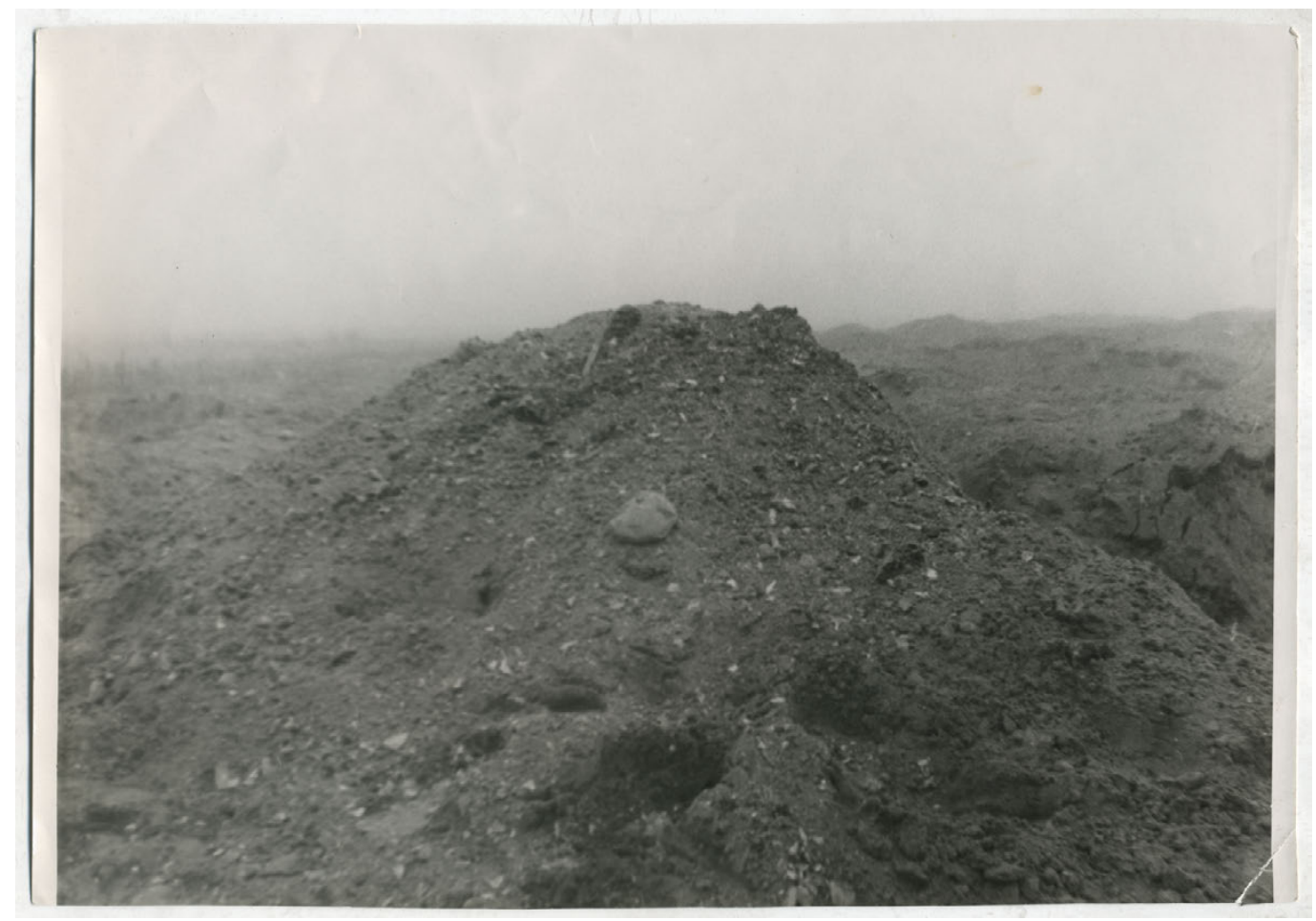

Podpis na rewersie (ołówkiem): „Treblinka. Obóz zagłady tuż po wyzwoleniu (popioły)” (fot. Jakub Byk) (ze zbiorów Żydowskiego Instytutu Historycznego im. Emanuela Ringelbluma w Warszawie, sygnatura TRE 029, dawniej 6221)

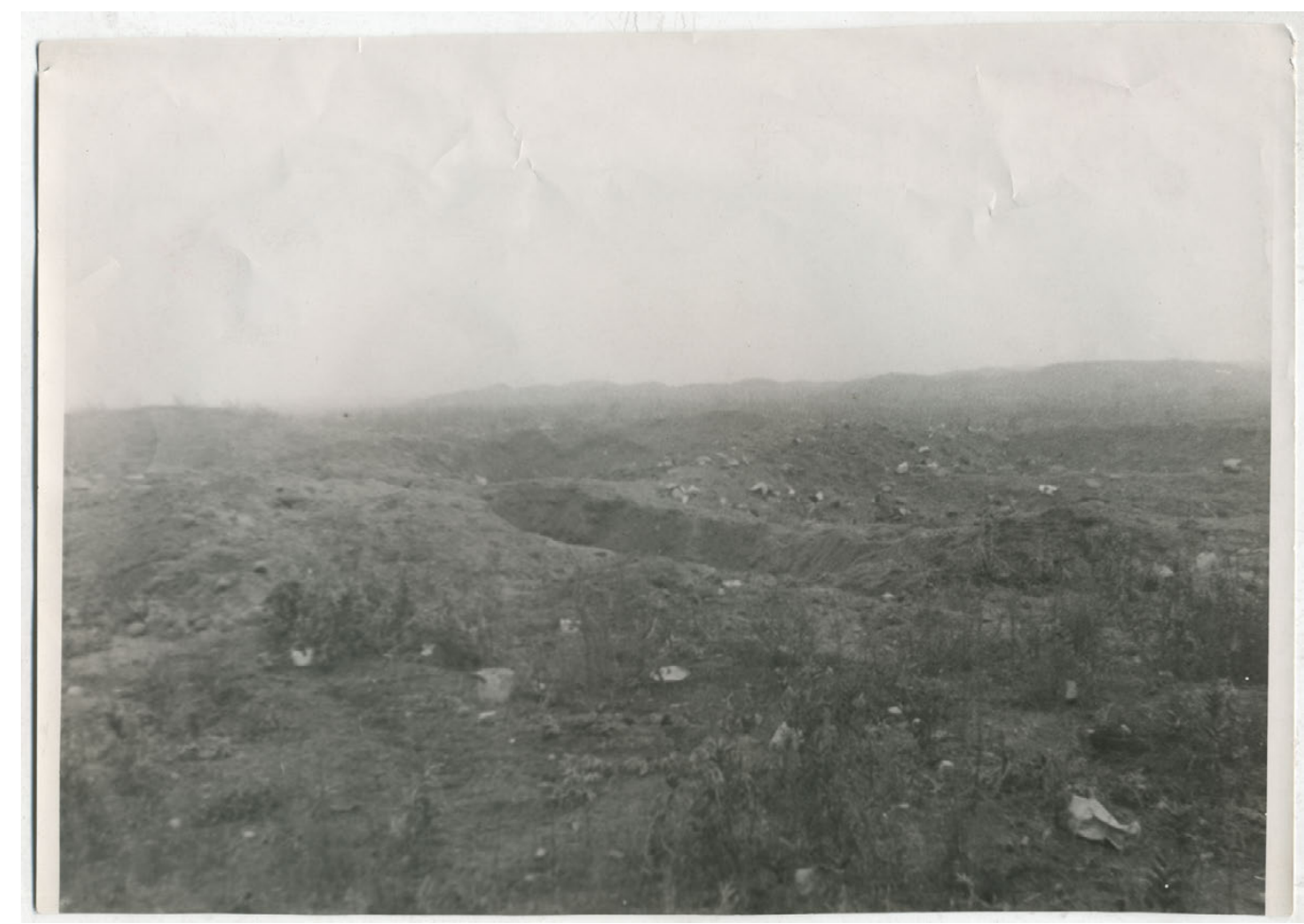

Podpis na rewersie (ołówkiem): „Treblinka. Obóz zagłady tuż po wyzwoleniu (popioły)” (fot. Jakub Byk) (ze zbiorów Żydowskiego Instytutu Historycznego im. Emanuela Ringelbluma w Warszawie, sygnatura TRE 030, dawniej 6449) 


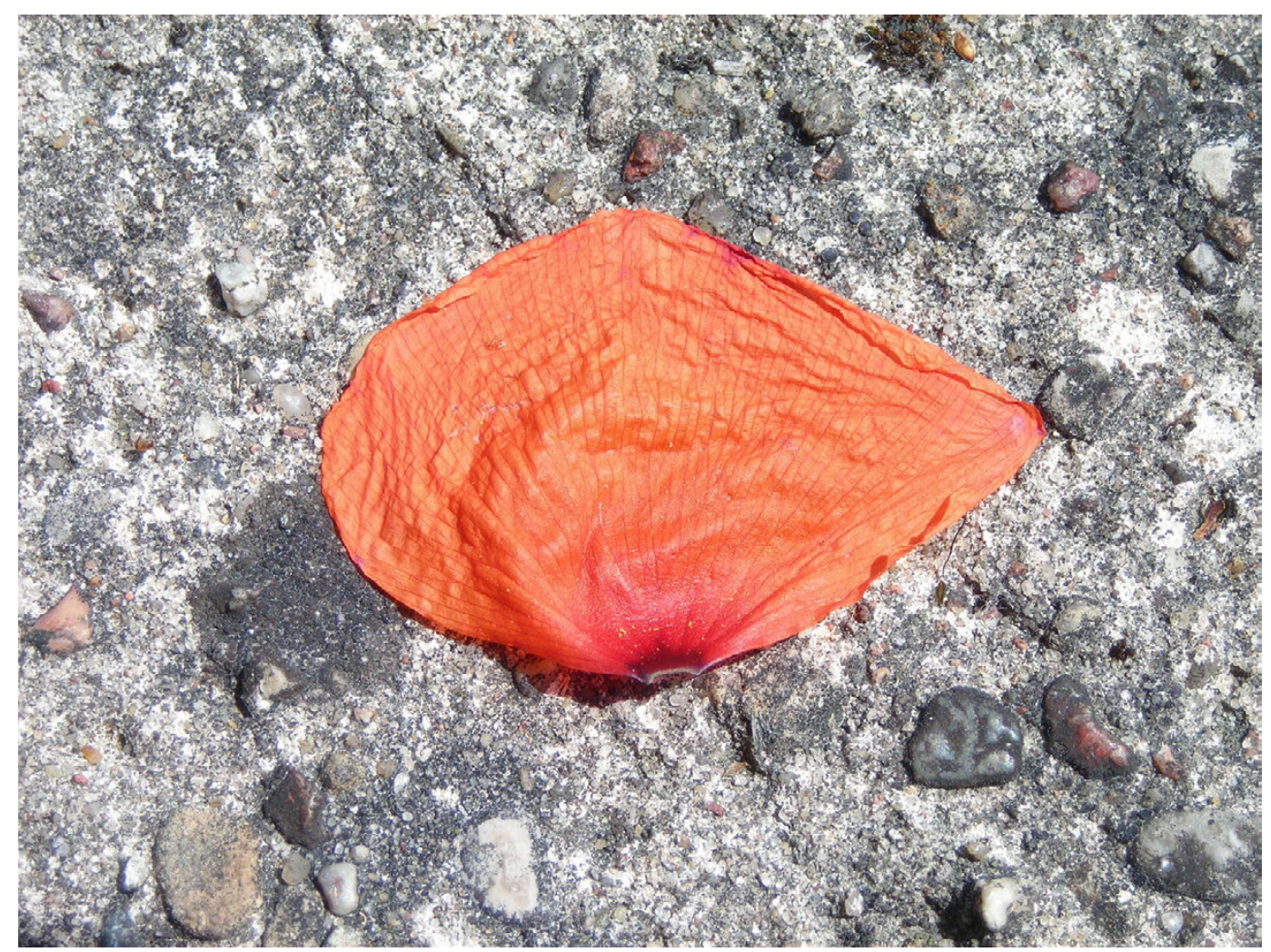

Treblinka II, 9 czerwca 2016 (fot. Elżbieta Janicka)

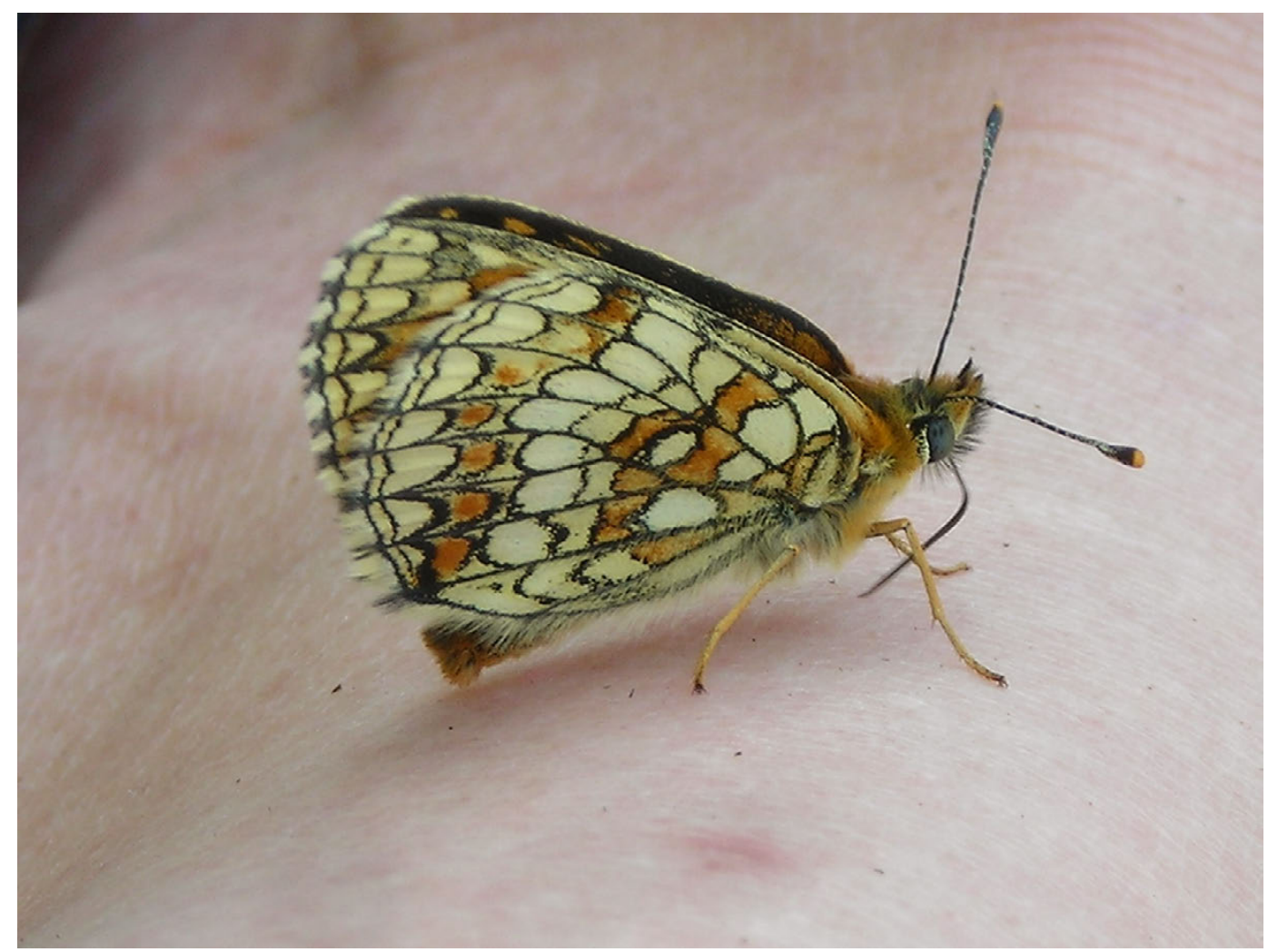

Treblinka II, 25 czerwca 2016 (fot. Elżbieta Janicka) 


\section{Bibliografia}

Adamczyk-Garbowska, M. (1998). My Warsaw is gone... Professor Chone Shmeruk interviewed by Monika Adamczyk-Garbowska. W Więź: Under one heaven: Poles and Jews (ss. 326-333). Towarzystwo Więź.

Auerbach, R. (2012a). Polskie Kolorado albo gorączka złota w Treblince [W Treblinka: Reportaż] (K. Szymaniak, Tłum.; M. Polit, Oprac.). Zagłada Żydów: Studia i Materiały, 2012(8), 70-72.

Auerbach, R. (2012b). Treblinka: Reportaż (K. Szymaniak, Tłum.; M. Polit, Oprac.). Zagłada Żydów: Studia i Materiały, 2012(8), 25-75.

Bal, M. (2002). Travelling concepts in the humanities: A rough guide. Toronto University Press.

Bateson, G., Jackson, D. D., Haley, J., \& Weakland, J. (1956). Toward a theory of schizophrenia. Behavioral Science, 1(4), 251-264. https://doi.org/10.1002/bs.3830010402

Bielawski, K. (2020). Zagłada cmentarzy żydowskich. Biblioteka Więzi.

Blok, A. (2001). Honour and violence. Polity.

Blößfeldt, K. (1929). Urformen der Kunst: Photographische Pflanzenbilder. Verlag Ernst Wasmuth A.G.

Borejsza, J. (2018). Okolice Treblinki. W J. Borejsza, Ostaniec, czyli ostatni świadek (ss. 222-226). Wielka Litera.

Brüggemeier, F.J., Cioc, M., \& Zeller, T. (Red.). (2005). How green were the Nazis? Nature, environment and nation in the Third Reich. Ohio University Press.

Bułhak, J. (1938a, listopad 1-15). Istota fotografii ojczystej. W Piękno Ziemi Śląskiej [Katalog wystawy] (s. 3). Sale Recepcyjne Sejmu Śląskiego w Katowicach.

Buthak, J. (1938b). Jaka ma być polska fotografia ojczysta. Przegląd Fotograficzny, 1938(11-12), 200-206.

Canin, M. (2018a). Gorączka złota. W M. Canin, Przez ruiny i zgliszcza: Podróż po stu zgładzonych gminach żydowskich w Polsce (M. Adamczyk-Garbowska, Tłum.; M. Adamczyk-Garbowska, E. Koźmińska-Frejlak, \& A. Trzciński, Przypisy; ss. 483-491). Nisza.

Canin, M. (2018b). Kosów. W M. Canin, Przez ruiny i zgliszcza: Podróż po stu zgładzonych gminach żydowskich w Polsce (M. Adamczyk-Garbowska, Tłum.; M. Adamczyk-Garbowska, E. Koźmińska-Frejlak, \& A. Trzciński, Przypisy; ss. 233-239). Nisza.

Canin, M. (2018c). Treblinka. W M. Canin, Przez ruiny i zgliszcza: Podróż po stu zgładzonych gminach żydowskich w Polsce (M. Adamczyk-Garbowska, Tłum.; M. Adamczyk-Garbowska, E. Koźmińska-Frejlak, \& A. Trzciński, Przypisy; ss. 445-450). Nisza.

Czyżewski, A. (2001). Trzewia Lewiatana: Antropologiczna interpretacja utopii miasta-ogrodu. Wydawnictwo Uniwersytetu Jagiellońskiego.

Dante. (1991). La Divine Comédie: L’Enfer (J. Risset, Oprac., Tłum. \& Wstęp). Flammarion.

Derrida, J. (1972). La mythologie blanche. W J. Derrida, Marges de la philosophie (ss. 247-325). Éditions de Minuit.

Derrida, J. (1986). Biała mitologia (W. Krzemień, Tłum.). Pamiętnik Literacki, 77(3), 283-318.

Dłubak, Z. (2013). Fotografia a sztuka dzisiaj. W M. Ziółkowska (Red.), Teoria sztuki Zbigniewa Dłubaka (ss. 153-159). Fundacja Archeologia Fotografii. (Pierwodruk: 1973).

Douglas, M. (2002). Purity and danger: An analysis of the concept of pollution and taboo. Routledge. https:// doi.org/10.4324/9780203361832

Dumont, L. (1967). Homo Hierarchicus: Essai sur le système des castes. Gallimard.

Dumont, L., \& Pocock, D. F. (1959). Pure and impure. Contributions to Indian Sociology, 3, 9-39.

Dunin, K. (2004). Polacy ludziom. W K. Dunin, Czytając Polskę (ss. 72-78). Wydawnictwo W.A.B.

Eco, U. (2009). Szaleństwo katalogowania (T. Kwiecień, Tłum.). Dom Wydawniczy Rebis. 
Edensor, T. (2002). National identity, popular culture and everyday life. Berg.

Edensor, T. (2004). Tożsamość narodowa, kultura popularna i życie codzienne (A. Sadza, Tłum.). Wydawnictwo Uniwersytetu Jagiellońskiego.

Ehrenburg, I., \& Grossman, W. (Red.). (2020). Czarna księga (J. Nalewajko-Kulikov, Oprac.). Żydowski Instytut Historyczny im. Emanuela Ringelbluma.

Elsner, J., \& Cardinal, R. (Red.). (1994). The cultures of collecting. Reaktion Books.

Fabre-Vassas, C. (1994). La bête singulière: Les juifs, les chrétiens et le cochon. Gallimard.

Geremek, B. (1987). Problem skalania w wyobraźni społecznej średniowiecza. W Obecność: Leszkowi Kołakowskiemu w 60 rocznicę urodzin (ss. 174-182). Aneks.

Glazar, R. (2011). Stacja Treblinka (E. Czerwiakowska, Tłum.). Ośrodek KARTA.

Gołubiew, Z., \& Rottenberg, A. (Red.). (1998). Alina Szapocznikow (1926-1973). Galeria Sztuki Współczesnej Zachęta.

Gołubiew, Z., Świszczowska-Piegdoń, M., Woźniak, Ł., Zemanek, A., \& Bartoszek, W. (2007). Zielnik Wyspiańskiego. Muzeum Narodowe w Krakowie.

Gomułka, S. (Red.). (2019). Transformacja polska 1991-1993. Wydawnictwo Naukowe Scholar.

Gomułka, S., \& Kowalik, T. (Red.). (2011). Transformacja polska: Dokumenty i analizy 1990. Wydawnictwo Naukowe Scholar.

Górski, J. (b.d.). Na przełomie dziejów (III 9776) [Rękopis]. Biblioteka Narodowa, Dział Rękopisów.

Grochowska, M. (2012, luty 11-12). Naznaczony: Rozmowa Magdaleny Grochowskiej z Anną Markiel o zagładzie domu Trynczerów. Gazeta Wyborcza, 34. https://wyborcza.pl/magazyn/1,124059,11124109,Naznaczony.html

Gross, J. T. (2003). Wokół Sąsiadów: Polemiki i wyjaśnienia. Pogranicze.

Gross, J. T. (2013). Macewy wrócą na cmentarz. W Ł. Baksik, Macewy codziennego użytku / Matzevot for everyday use (ss. 15-16). Wydawnictwo Czarne.

Gross, J. T., \& Grudzińska-Gross, I. (2011). Złote żniwa: Rzecz o tym, co się działo na obrzeżach zagłady Żydów. Znak.

Grossman R. (Reż.). (2018). Kto napisze naszą historię [Film]. Katahdin Productions; Arte/NDR; EC1Łódź Miasto Kultury; Match\&Spark; Mazowiecki Fundusz Filmowy.

Gros[s]man, W. (1945). Piekło Treblinki: Reportaż literacki. Wydawnictwo „Literatura Polska”.

Grossman, W. (2009). Życie i los (J. Czech, Tłum.). Wydawnictwo W.A.B.

Grossman, W. (2020). Treblinka. W I. Ehrenburg \& W. Grossman (Red.), Czarna księga (ss. 679-708). Żydowski Instytut Historyczny im. Emanuela Ringelbluma.

Grynberg, H. (1984a). Ludzie Żydom zgotowali ten los. W H. Grynberg, Prawda nieartystyczna (ss. 65-88). Archipelag.

Grynberg, H. (1984b). Obsesyjny temat. W H. Grynberg, Prawda nieartystyczna (ss. 133-144). Archipelag.

Grynberg, H. (1999). Ojczyzna. Wydawnictwo W.A.B.

Grynberg, H. (2012). Historia polsko-żydowska. W H. Grynberg, Monolog polsko-żydowski (ss. 7-38). Wydawnictwo Czarne.

Grzesiuk-Olszewska, I. (1995). Polska rzeźba pomnikowa w latach 1945-1995. Neriton.

Grzesiuk-Olszewska, I. (2019). Konkurs oświęcimski: Projekty niezrealizowane. W A. Tarasiuk \& A. Miczko (Red.), Pomnik: Europa Środkowo-Wschodnia 1918-2018 (ss. 44-47). Muzeum Rzeźby im. Xawerego Dunikowskiego w Królikarni.

Haupt, A. (1961, luty 11). Stacja końcowa: Śmierć. Głos Wybrzeża, 3, 5. 
Janicka, E. (2006). Hortus Judeorum: Refleksje oddechowe i pokarmowo-trawienne na marginesie pracy „Miejsce nieparzyste”. W R. Dziadkiewicz \& E. Tatar (Red.), Imhibition (ss. 99-109). Muzeum Narodowe w Krakowie; Ha!art.

Janicka, E. (2014-2015). Pamięć przyswojona: Koncepcja polskiego doświadczenia zagłady Żydów jako traumy zbiorowej w świetle rewizji kategorii świadka. Studia Litteraria et Historica, 2014-2015(3-4), 148227. https://doi.org/10.11649/slh.2015.009

Janicka, E., \& Żukowski, T. (2016). Przemoc filosemicka? Nowe polskie narracje o Żydach po roku 2000. Wydawnictwo Instytutu Badań Literackich Polskiej Akademii Nauk.

Jung, K. (b.d.). Autorskie fotografie warsztatowe (studyjne) / Artist's working photographs (studies). Krzysztof Jung. http://www.krzysztofjung.com/fotografie-photographs/fotografie

Kącki, M. (2016, lipiec 21). Zdrajczyni: Z Rūtą Vanagaité, autorką książki Nasi o mordowaniu Żydów przez Litwinów, rozmawia Marcin Kącki. Gazeta Wyborcza: Duży Format, 20-21.

Kertész, I. (1975). Sorstalanság. Magvető Könyvkiadó.

Kertész, I. (2010). Los utracony (K. Pisarska, Tłum.). Wydawnictwo W.A.B.

Kielak, A. M. (2004). Zielnik Elizy Orzeszkowej: Nieznany zabytek botaniczny przechowywany w zbiorach Poznańskiego Towarzystwa Przyjaciót Nauk. Wydawnictwo Kontekst.

Kobendza, R., \& Sokołowska, B. (2012). Notes botaniczny / Botanical notebook (K. Kościuczuk, Tłum.). Fundacja Archeologia Fotografii.

Kobro, K., \& Strzemiński, W. (1993). Kompozycja przestrzeni: Obliczenia rytmu czasoprzestrzennego. Muzeum Sztuki w Łodzi. (Pierwodruk: 1931, nakładem autorów).

Kopówka, E. (2009). Plan kamieni symbolicznych. Muzeum Walki i Męczeństwa w Treblince.

Kopówka, E. (Red.). (2013a). Co wiemy o Treblince? Stan badań / What do we know about Treblinka? The current state of research. Muzeum Regionalne w Siedlcach.

Kopówka, E. (2013b). Karny obóz pracy w Treblince. W E. Kopówka, Co wiemy o Treblince? Stan badań / What do we know about Treblinka? The current state of research (ss. 45-62). Muzeum Regionalne w Siedlcach.

Kopówka, E. (2014). Obóz zagłady. W E. Kopówka, Plan kamieni symbolicznych (2. wyd., b.n.). Muzeum Walki i Męczeństwa w Treblince. https://muzeumtreblinka.eu/wp-content/uploads/2018/12/plan_symbolicznych_ kamieni.pdf

Kosmopolityczne organizmy. (b.d.). W Encyklopedia PWN. Pobrano 1 sierpnia 2019, z https://encyklopedia. pwn.pl/haslo/kosmopolityczne-organizmy;3926165.html

Kowalik, T. (2009). www.Polska transformacja.pl. Warszawskie Wydawnictwo Literackie MUZA SA.

Kowalska, A. (2012). Na naszym wybrukowanym macewami podwórku: Wywiad z Łukaszem Baksikiem. W Ł. Baksik, Macewy codziennego użytku / Matzevot for everyday use (ss. 17-22). Wydawnictwo Czarne.

Krzepicki, A. J. (2017). Człowiek uciekł z Treblinek... Rozmowy z powracającym (B. Engelking \& A. Skibińska, Red.). Żydowski Instytut Historyczny.

Księga Psalmów. (2003). (A. Jankowski \& L. Stachowiak, Tłum.). W Biblia Tysiąclecia. Pismo święte Starego i Nowego Testamentu. Pallotinum. https://biblia.deon.pl/rozdzial.php?id=925

Kwiet, K. (2019). Forests and the final solution. W A. Klei \& K. Stoll (Red.), Leerstelle(n)? Der deutsche Vernichtungskrieg 1941-1944 und die Vergegenwärtigungen des Geschehens nach 1989 (ss. 41-70). Neofelis Verlag.

Landau-Czajka, A. (2015). Polska to nie oni: Polska i Polacy w polskojęzycznej prasie żydowskiej II Rzeczypospolitej. Żydowski Instytut Historyczny im. Emanuela Ringelbluma.

Landsberger, F. (1957). The sacred direction in Synagogue and Church. Hebrew Union College Annual, 28, $181-203$.

Langer L. L. (2015). Świadectwa Zagłady w rumowisku pamięci (M. Szuster, Tłum.). Żydowski Instytut Historyczny im. Emanuela Ringelbluma. 
Lanzmann, C. (Reż.). (1985). Shoah [Film]. Historia; Les Films Aleph; Ministère de la Culture de la Republique Française.

Lanzmann, C. (2009). La lièvre de Patagonie: Mémoires. Gallimard.

Lanzmann, C. (2010). Zając z Patagonii: Pamiętniki (M. Ochab, Tłum.). Wydawnictwo Czarne.

Lanzmann, C. (2012). The Patagonian hare: A memoir (F. Wynne, Tłum.). Farrar, Straus and Giroux.

Leśniakowska, M. (1994). U źródeł polskiej fotografiki. Dagerotyp, 1994(3), 3-12.

Luksemburg, R. (2009). Zielnik / Herbarium (J. Schütrumpf, Wstęp; H. Werblan-Jakubiec \& J. Dolatowski, Komentarz). Fundacja Róży Luksemburg; Wydawnictwo Baobab.

Luxemburg, R. (b.d.). Foreword to the anthology: "The Polish question and the socialist movement” (1905). Marxist.org. https://www.marxists.org/archive/luxemburg/1905/misc/polish-question.htm

Makower, H. (1987). Pamiętnik z getta warszawskiego: Październik 1940 - styczeń 1943 (N. Makower, Red.). Ossolineum.

Małczyński, J. (2018). Krajobrazy Zagłady: Perspektywa historii środowiskowej. Instytut Badań Literackich Polskiej Akademii Nauk.

Masson, S. E. (2016). Introduction. W T. C. Masson, My Kaddish: Memoir of a childhood in the Warsaw Ghetto (J. Moussaieff Masson \& S. Esther Masson, Red.; ss. 1-3). CreateSpace Independent Publishing Platform.

Masson, T. C. [Teresa Klara Alter]. (2016). My Kaddish: Memoir of a childhood in the Warsaw Ghetto (J. Moussaieff Masson \& S. Esther Masson, Red.). CreateSpace Independent Publishing Platform.

Matyjaszek, K. (2016). Mur i okno: Gruz getta warszawskiego jako przestrzeń narracyjna Muzeum Historii Żydów Polskich POLIN. Studia Litteraria et Historica, 2016(5), 1-33. https://doi.org/10.11649/slh.2016.004

Matyjaszek, K. (2019). Produkcja przestrzeni żydowskiej w dawnej i wspótczesnej Polsce. Universitas.

Michalczak, D. (2015, maj 15). „Nie zapomnij o mnie”, czyli Święto Polskiej Niezapominajki. Wiadomości Zbąszyń. https://zbaszyn.naszemiasto.pl/nie-zapomnij-o-mnie-czyli-swieto-polskiej-niezapominajki/ar/c8-3384481

Miłosz, C. (1984). Traktat poetycki. W C. Miłosz, Wiersze (T. 2, ss. 6-44). Wydawnictwo Literackie. (Pierwodruk: 1957).

Młynarczyk, J. A. (2013). Niemiecki obóz zagłady dla ludności żydowskiej w Treblince. W E. Kopówka (Red.), Co wiemy o Treblince? Stan badań (ss. 63-100). Muzeum Regionalne w Siedlcach.

Moore, S., Meighan, I., \& King, M. (Red.). (2011). Megality: Kamienne giganty (O. Żórawska, Tłum.) [Katalog wystawy]. Państwowe Muzeum Archeologiczne.

Mortkowicz-Olczakowa, H. (2006). Czechowicz: W poszukiwaniu ukrytego miasta. Scriptores, 2006(30), 23.

Murawska-Muthesius, K. (2002, maj 20). Oskar Hansen and the Auschwitz „Countermemorial” (1958-59). Artmargins. https://artmargins.com/oskar-hansen-and-the-auschwitz-qcountermemorialq-1958-59/

Nirenberg, D. (2013). Anti-Judaism: The Western tradition. W. W. Norton.

Olczak-Ronikier, J. (2002). W ogrodzie pamięci. Znak.

Ost, D. (2005). The defeat of Solidarity: Anger and politics in postcommunist Europe. Cornell University Press. https://doi.org/10.7591/9781501729270

Panofsky, E. (1955). „Et in Arcadia ego”: Poussin and the elegiac tradition. W E. Panofsky, Meaning in the visual arts: Papers in and on art history (ss. 295-320). Doubleday Anchor Books.

Panofsky, E. (1971). „Et in Arcadia ego”: Poussin i tradycja elegijna (A. Morawińska, Tłum.). W E. Panofsky, Studia z historii sztuki (J. Białostocki, Red.; ss. 324-342). Państwowy Instytut Wydawniczy.

Perechodnik, C. (2004). Spowiedź: Dzieje rodziny żydowskiej podczas okupacji hitlerowskiej w Polsce (D. Engel, Red.). Ośrodek KARTA.

Pierściński, P. (b.d.). Pisanie krajobrazów [Rękopis].

Pierściński, P. (2004). Czas krajobrazu: Antologia tekstów z lat 1975-2004. Muzeum Historii Fotografii. 
Pierściński, P. (2005). Pagór. Biblioteka Świętokrzyska.

Pietrasik, A. (2010). Traversing monumentality: Successive designs for the Auschwitz Monument. W E. Toniak (Red.), Moore and Auschwitz (b.n.). Adam Mickiewicz Institute.

Pomian, K. (1987). Collectionneurs, amateurs et curieux: Paris, Venise: XVle-XVIIle siècle. Gallimard.

Pomian, K. (2012). Zbieracze i osobliwości: Paryż - Wenecja XVI-XVIII wiek (A. Pieńkos, Tłum.). Wydawnictwo W.A.B.

Pratt, M. L. (1992). Imperial eyes: Travel writing and transculturation. Routledge. https://doi. org/10.4324/9780203163672

Psalmy. (1883). (I. Cylkow, Tłum.). Drukarnia Alexandra Ginsa.

http://bibliepolskie.pl/_pliki/cylkow/cpliki/5105743945116880921686007193241592687559.php

Radecka, K. (Reż.). (2011). Treblinka [DVD]. Akademia Sztuk Pięknych w Gdańsku.

Radecka, K. (2013). Upamiętnienie zrealizowane w Treblince. W E. Kopówka (Red.), Co wiemy o Treblince? Stan badań (ss. 307-314). Muzeum Regionalne w Siedlcach.

Rajchman, J. (2011). Ocalatem z Treblinki: Wspomnienia z lat 1942-1943 (B. Szwarcman-Czarnota, Tłum.). Czytelnik.

Reszka, P. P. (2019). Płuczki: Poszukiwacze żydowskiego złota. Agora.

Risset, J. (1991). Introduction. W Dante, La divine comédie: L'enfer (ss. 7-16). Flammarion.

Ro'i, Y. (2010). Black book. W YIVO Encyclopedia of Jews in Eastern Europe. https://yivoencyclopedia.org/ article.aspx/Black_Book

Rose, R. S. (2006). Krytyczny słownik mitów i symboli nazizmu (Z. Jakubowska \& A. Rurarz, Tłum.; R. Argullol, Wprowadzenie). Wydawnictwo Sic!

Rusiniak, M. (2008). Obóz zagłady Treblinka II w pamięci społecznej (1943-1989). Neriton.

Sauer, C. (2014). Morfologia krajobrazu (M. Górna, Tłum.). W B. Frydryczak \& D. Angutek (Red.), Krajobrazy: Antologia tekstów (ss. 21-34). Wydawnictwo Poznańskiego Towarzystwa Przyjaciół Nauk.

Schama, S. (1995). Landscape and memory. Alfred A. Knopf.

Schieb, B., Voigt, M., \& Weinstein, F. (2006). Aufzeichnungen aus dem Versteck: Erlebnisse eines polnischen Juden 1939-1946. Lukas Verlag.

Schultze-Naumburg, P. (1905). Die Entstellung unseres Landes. Gebauer-Schwetschke.

Seidman, H. (1998). Du fond de l'abîme: Journal du ghetto de Varsovie. Plon.

Sereny, G. (2002). W stronę ciemności: Rozmowy z komendantem Treblinki (J. K. Milencki, Tłum.). Cyklady.

Sitkowska, M. (Red.). (2001). Krzysztof Jung (1951-1998). Muzeum im. Xawerego Dunikowskiego w Królikarni.

Spector, S. (1990). „Aktion 1005”: Effacing the murder of millions. Holocaust and Genocide Studies, 5(2), 157-173. https://doi.org/10.1093/hgs/5.2.157

Sprawozdanie ze Zjazdu Delegatów Polskich Towarzystw Fotograficznych w Warszawie. (1937). Przegląd Fotograficzny, 1937(11), 205-207.

Stow, K. (2006). Jewish dogs: An image and its interpreters: Continuity in Catholic-Jewish encounters. Stanford University Press. https://doi.org/10.11126/stanford/9780804752817.001.0001

Sturdy Colls, C. (2012). 0 tym, co minęło, lecz nie zostało zapomniane: Badania archeologiczne na terenie byłego obozu Zagłady w Treblince (E. Felska \& J. Giebułtowski, Tłum.). Zagłada Żydów: Studia i Materiały, 2012(8), 83-118. https://doi.org/10.32927/ZZSiM.628

Sturdy Colls, C. (2013). Ocena archeologiczna na terenie byłego obozu zagłady w Treblince. W E. Kopówka (Red.), Co wiemy o Treblince? Stan badań (ss. 207-215). Muzeum Regionalne w Siedlcach.

Sturdy Colls, C. (2015). Badania archeologiczne w Obozie Zagłady i Karnym Obozie Pracy w Treblince (P. Totwiński, Tłum.). W E. Kopówka (Red.), Treblinka: Historia i pamięć (ss. 78-85). Muzeum Regionalne w Siedlcach. 
Subbotko, D. (2011, październik 13). Żyję dla przeszłości: Z Henrykiem Grynbergiem rozmawia Donata Subbotko. Gazeta Wyborcza: Duży Format, 16-18.

Sulej, K. (2011, listopad 3). Chodziłam po ludziach i pytałam o Piekło: Z Ewą Andrzejewską rozmawia Karolina Sulej. Gazeta Wyborcza: Duży Format, 10-11.

Syreński, S. (2017a). O Żydziech rzecz krótka. W S. Syreński, Zielnik Syreniusza: Druk czcionką współczesna (M. Łuczaj, Red.; T. 5, ss. 1536-1539). Krośnieńska Oficyna Wydawnicza.

Syreński, S. (2017b). Zielnik Syreniusza: Druk czcionką współczesną (M. Łuczaj, Red.). Krośnieńska Oficyna Wydawnicza.

Szabó, I. (Reż.). (1999). Sunshine [Film]. Filmfonds Wien; Hungarian Motion Picture Fund; InterCom; ISL Film; Kinowelt Filmproduktion; Movie Network, The (TMN); Österreichischer Rundfunk (ORF); Serendipity Point Films; Téléfilm Canada; TV2.

Szuchta, R. (2013). Edukacja w miejscu pamięci. W E. Kopówka (Red.), Co wiemy o Treblince? Stan badań (ss. 29-43). Muzeum Regionalne w Siedlcach.

Taborska, H. (2002). Rozstrzelane kamienie. Polityka, 2002(30(2360)), 65-67.

Taborska, H. (2003). Art in places of death: Polish signs of memory in the Nazi death camps. Kultura Wspótczesna, 2003(4(38)), 38-62.

Tokarska-Bakir, J. (2008). Legendy o krwi: Antropologia przesądu. Wydawnictwo W.A.B.

Wajda, A. (1996). [Bez tytułu]. W Z. Gołubiew (Red.), To lubię. Muzeum Narodowe w Krakowie.

Weinstein, E. (2008). 17 dni w Treblince (R. Zubkowicz, Tłum.). Towarzystwo Przyjaciół Ziemi Łosickiej.

Wiatr, E., Engelking, B., \& Skibińska, A. (Red.). (2013). Archiwum Ringelbluma. T. 13. Ostatnim etapem przesiedlenia jest śmierć: Pomiechówek, Chełmno nad Nerem, Treblinka. Żydowski Instytut Historyczny.

Wiernik, J. (2003). Rok w Treblince / A year in Treblinka. Rada Ochrony Pamięci Walk i Męczeństwa.

Willenberg, S. (2004). Bunt w Treblince (A. Żbikowski, Red.). Więź.

Wóycicka, Z. (2009). Chrześcijański pomnik żydowskiej martyrologii? Niezrealizowany projekt upamiętnienia terenu byłego obozu Zagłady w Treblince z 1947 roku. W Z. Wóycicka, Przerwana żałoba: Polskie spory wokót pamięci nazistowskich obozów koncentracyjnych i zagłady 1944-1950 (ss. 333-361). TRIO.

Zagajewski, A. (1988). Oglądając „Shoah” w pokoju hotelowym w Ameryce. Zeszyty Literackie, 1988(21), 50-51.

Zaleski, M. (2000). „Ludzie ludziom”...? „Ludzie Żydom”...? Świadectwo literatury? W A. Brodzka-Wald, D. Krawczyńska, \& J. Leociak (Red.), Literatura polska wobec Zagłady (ss. 89-103). Żydowski Instytut Historyczny im. Emanuela Ringelbluma.

Zaremska, H. (2011). Żydzi w średniowiecznej Polsce: Gmina krakowska. Instytut Historii Polskiej Akademii Nauk.

Zawadka, A. P. (2015). Upamiętnianie Treblinki. W E. Kopówka (Red.), Treblinka: Historia i pamięć (ss. 32-56). Muzeum Regionalne w Siedlcach.

Ząbecki, F. (1977). Wspomnienia dawne i nowe. Instytut Wydawniczy PAX.

Zemon Davis, N. (2012). Metamorfozy: Maria Sibylla Merian (B. Hlebowicz, Tłum.). W N. Zemon Davis, Kobiety na marginesach: Trzy siedemnastowieczne życiorysy (ss. 147-209). Wydawnictwo Naukowe PWN.

Ziesing, H. (2004). A flowery paradise in Auschwitz: The garden of the Kommandant of Auschwitz Rudolf Höß. Centropa: A Journal of Central European Architecture and Related Arts, 4(2), 141-148.

Ziontek, A. (Red.). (2016). Żydzi Kosowa Lackiego. Miejsko-Gminny Ośrodek Kultury. 


\section{Herbarium Polonorum (Heimatphotographie)}

Abstract: The main theme of the text is the wartime and postwar history of the area of the German Nazi extermination camp Treblinka II, seen from the perspective of the production of landscape - with a special focus on the identity aspect, i.e. the nationalization of nature and the naturalization of the nation. The argument refers to imaging conventions of nature and ethnographic photography, like the German Heimatphotographie and the Polish Fatherland Photography, that go along with landscape production.

This paper also touches upon the issue of classification as the principle organizing the workings of the human mind as well as the uses made of classification in terms of cognition and identity - up to and including the deadly consequences thereof. Another crucial point of reference is the history of the herbarium as a form of organizing knowledge (Maria Sibylla Merian, Rosa Luxemburg, Szymon Syreński) and its connections with the visual arts (Krzysztof Jung, Alina Szapocznikow).

The rich iconography illustrates the analyzed representation patterns, with particular focus on the axiosemiotics of Polish antisemitism, going back to its elitist forms in Jagiellonian Poland. The text summarizes fifteen years of the author's work on Herbarium, a photographic project carried out on the site of the former German Nazi extermination camp Treblinka II.

Keywords: antisemitism; Heimatphotographie; Holocaust; landscape; nature photography; environmental history; Treblinka; herbarium

Citation: Janicka, E., Herbarium Polonorum (Heimatphotographie). Studia Litteraria et Historica, 2020(9), Article 2266. https://doi.org/10.11649/slh.2266

This is an Open Access article distributed under the terms of the Creative Commons Attribution 3.0 PL License, which permits redistribution, commercial and non-commercial, provided that the article is properly cited. http://www.creativecommons.org/licenses/by/3.0/pl (c) The Author(s) 2020

Publisher: Institute of Slavic Studies, Polish Academy of Sciences, Warsaw, Poland Author: Elżbieta Janicka, Institute of Slavic Studies, Polish Academy of Sciences, Warsaw, Poland

ORCID: https://orcid.org/0000-0002-0945-6886

Correspondence: slh@ispan.waw.pl

The preparation of this work was self-financed by the author.

Competing interests: The author is a member of the Editorial Team of the journal. 